\title{
Fusarium-Befall bei Emmer und Nacktgerste
}

\section{Dissertation}

zur Erlangung des Doktorgrades

Dr. rer. nat.

der Fakultät für Agrarwissenschaften

der Georg-August-Universität Göttingen

vorgelegt von

Kai Eggert

geboren in Eisenhüttenstadt

Göttingen, Mai 2010 
D7

1. Referentin:

Prof. Dr. Elke Pawelzik

2. Korreferent:

Prof. Dr. Petr Karlovsky

Tag der mündlichen Prüfung:

15. Juli 2010 


\section{Inhaltsverzeichnis}

Inhaltsverzeichnis i

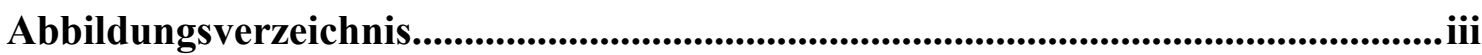

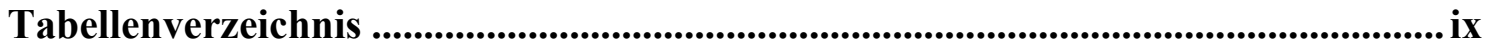

$1 \quad$ Vorwort ................................................................................................. 1

$2 \quad$ Einleitung ........................................................................................... 3

2.1 Emmer (Triticum turgidum L. ssp. dicoccum) ................................................ 3

$2.2 \quad$ Nacktgerste (Hordeum vulgare ssp. nudum) ............................................... 8

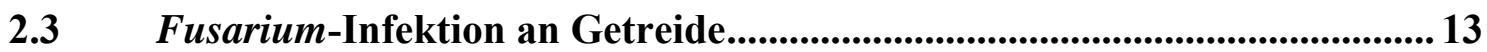

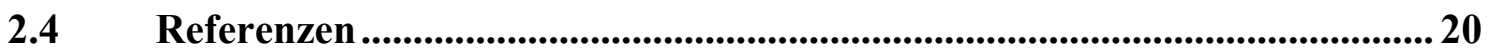

$3 \quad$ Zielstellung.................................................................... 27

4 Material und Methoden......................................................29

$5 \quad$ Ergebnisse und Diskussion............................................... 33

5.1 Fusarium infection and toxin formation in emmer and naked barley....... 33

5.2 Effects of Fusarium Infection on the Phenolics in Emmer and Naked

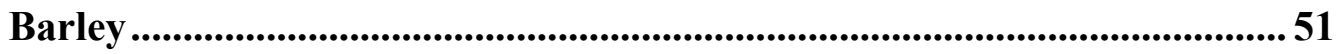

5.3 The influence of Fusarium infection and growing location on the quantitative protein composition of (Part I) emmer (Triticum dicoccum) 71

5.4 The influence of Fusarium infection and growing location on the quantitative protein composition of (Part II) naked barley (Hordeum vulgare nudum). .93

5.5 In vitro-degradation of wheat gluten fractions by Fusarium graminearum proteases

5.6 Proteome analysis of Fusarium infection in emmer grains (Triticum dicoccum) ............................................................................................139

5.7 Proteome analysis of Fusarium head blight in grains of naked barley.... 161

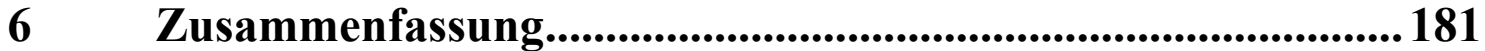




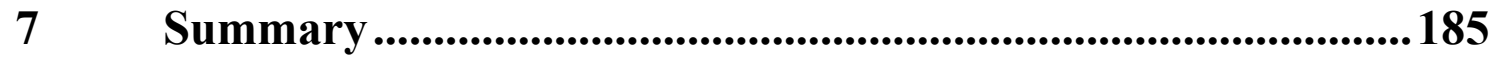

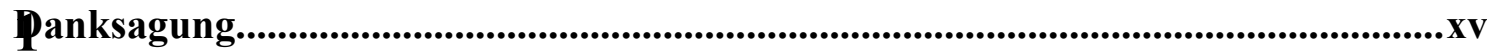

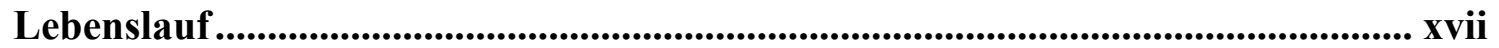




\section{Abbildungsverzeichnis}

\section{Einleitung}

Abb. 1 Gebiet des fruchtbaren Halbmonds im östlichen Mittelmeer [5]

Abb. 2 Emmer-Ähre [BBCH* 89] (a), reife geerntete und gereinigte Vesen [BBCH 99] (b), entspelzte Körner [BBCH 99] (c), [Fotos Eggert 2007, 2008] * BBCH-Skala: Entwicklungsstadien mono- und dikotyler Pflanzen (Uwe Meier, Biologische Bundesanstalt für Land- und Forstwirtschaft, 2001 nach Hack et al. 1992) .................... 5

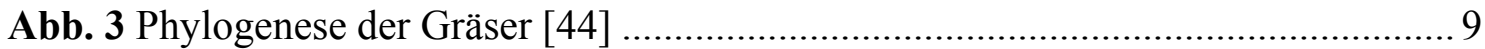

Abb. 4 Nacktgerste [BBCH 65] (a), reife geerntete und gereinigte Körner [BBCH 99] (b), gefärbte Nacktgerste [BBCH 75] (c) [Fotos Eggert 2007, 2008] 10

Manuskript: Fusarium infection and toxin formation in emmer and naked barley

Figure 1 Correlation between total Fusarium DNA and total toxin content (DON+3-AcDON) in emmer grains $(\mathrm{n}=3)$ after natural $(-)$ and artificial $(+)$ infection.

Figure 2 Correlation between total Fusarium DNA and total toxin content (DON/3-AcDON) in flour made from naked barley $(\mathrm{n}=7)$ after natural $(-)$ and artificial $(+)$ infection

Figure 3 Correlation between total Fusarium DNA and total toxin content (DON/3-AcDON) in flour made from emmer glume $(\mathrm{n}=3)$ after natural $(-)$ and artificial $(+)$ infection

Figure 4 Percentage of F. graminearum and F. culmorum in naturally (-) and artificially $(+)$ infected grain and glume.

Figure 5 Percentage of deoxynivalenol (DON) and 3-acetyl-deoxynivalenol (3-AcDON) of total toxin in naturally (-) and artificially $(+)$ infected grain and glume flour 44 Publikation: Effects of Fusarium Infection on the Phenolics in Emmer and Naked Barley

Figure 1 Extraction procedure of grain phenolics, separated procedures for the extraction of methanol-soluble phenolics and covalent bound phenolics for quantitative RP-HPLC. Aqueous methanol was made of $80 \%$ methanol with $20 \%$ dest. $\mathrm{H}_{2} \mathrm{O}(\mathrm{v} / \mathrm{v})$ containing $1 \%$ acetic acid, $20 \mathrm{ml} 0.1 \mathrm{M} \mathrm{H}_{2} \mathrm{SO}_{4}$ used for hydrolysis of covalent bound phenolics; $5 \mathrm{ml} 0.2 \mathrm{M} \mathrm{H}_{2} \mathrm{SO}_{4}$ used for hydrolysis of methanol-soluble phenolics, end concentration after re-suspension for analysis was $0.5 \mathrm{~g}_{\text {flour } \mathrm{ml}^{-1}}$ 56 
Figure 2 Supposed biosynthesis of caffeic, ferulic, and p-coumaric acid as well as catechin in the grains; preferred ways of synthesis in grain and those postulated after Fusarium infection in barley are shown with thick arrows; normal arrows show the steps of synthesis of ferulic acid, the main phenol in grain; dotted arrows showed synthesis of phenolic acids postulated by the literature 63

Publikation: The influence of Fusarium infection and growing location on the quantitative protein composition of (Part I) emmer (Triticum dicoccum)

Figure 1 RP-HPLC of protein fractions in emmer [Linie 9-102] and wheat [Amaretto]:

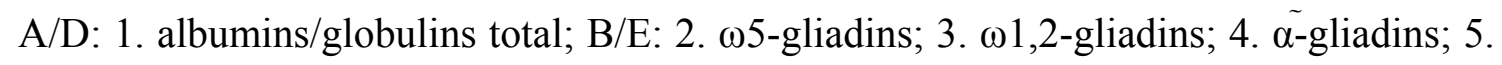
$\tilde{\gamma}$-gliadins, total gliadin (prolamine) from first to last bar; C/F: $\omega b$-gliadins; 7. HMWGS; 8: LMW-GS; total glutenin (glutelins) from first to last bar. .76

Figure 2 Variations in percent of protein fractions and types in the whole flour from the three emmer cultivars and the wheat cultivar from two growing locations after artificial Fusarium infection in comparison to natural infection .86

Figure 3 Quantities of protein fractions in emmer $(n=3)$ and wheat cultivar at two locations (SH: Sattenhausen; RH: Reinshof) according to the N supply (RH $>\mathrm{SH})$; the significant changes for emmer are denoted as p-values.....

Figure 4 Quantities of gliadin types in three emmer cultivars and a wheat cultivar at two locations (SH: Sattenhausen; RH: Reinshof) dependent on the N supply $(\mathrm{RH}>\mathrm{SH})$; significant changes for emmer are denoted as p-values. . .88

Figure 5 Quantities of glutenin types in emmer $(n=3)$ and wheat cultivar at two locations (SH: Sattenhausen; RH: Reinshof) dependent on N supply (RH > SH); significant changes for emmer are denoted as p-values .89

Publikation: The influence of Fusarium infection and growing location on the quantitative protein composition of (Part II) naked barley (Hordeum vulgare nudum)

Figure 1 Protein fractions in naked barley [Lawina]: A: albumins + globulins total; B: C-hordeins; $\gamma$-hordeins; total hordeins (prolamins) from first to last bar; C: D-hordenins; B-hordenins, total hordenins (glutenins) from first to last line.

Figure 2 Variations in \% of protein fractions in naked barley $(\mathrm{n}=7)$ and summer barley $(n=1)$ in whole grain flour from two growing locations after artificial Fusarium infection in comparison to natural infection, $\mathrm{ALG}=$ albumins + globulins 104 
Figure 3 Protein content in grains of naked barley $(n=7)$ and summer barley $(n=1)$ at two locations (SH: Sattenhausen; RH: Reinshof) with different N supplies; significant changes for naked barley are denoted as p-values

Figure 4 Quantities of albumins/globulins, hordein (prolamins) and hordenin (glutelins) protein fractions in naked barley $(\mathrm{n}=7)$ and summer barley $(\mathrm{n}=1)$ at two locations $(\mathrm{SH}$ : Sattenhausen; RH: Reinshof) in grain with different N supplies; significant changes for naked barley are denoted as p-values

Figure 5 Quantities of hordein and hordenin fractions in naked barley $(n=7)$ and summer barley $(\mathrm{n}=1)$ at two locations (SH: Sattenhausen; RH: Reinshof) in grain with different $\mathrm{N}$ supplies; significant changes for naked barley are denoted as p-values .... 108

\section{Manuskript: In vitro-degradation of wheat gluten fractions by Fusarium graminearum proteases}

Figure 1 Model system for the isolation of Fusarium graminearum protease extract and degradation of wheat gluten and gluten fractions.

Figure 2a Results of the fractionated and freeze-dried samples showing the allocation of the RP-HPLC peaks of wheat gliadin to the corresponding identified molecular weights by SDS-Page in $\mathrm{kDa}$ (molecular weight); mAbs, micro absorption units.

Figure 2b Results of the fractionated and freeze-dried samples showing the allocation of the RP-HPLC peaks of wheat glutenin to the corresponding identified molecular weights by SDS-Page in $\mathrm{kDa}$ (molecular weight); mAbs, micro absorption units

Figure 2c Allocation of the wheat gliadin and glutenin subfractions to the corresponding isolated and purified control. Standard (A: phosphorylase; B: bovine serum albumin; C: ovalbumin; D: carbonic anhydrase; E: trypsin inhibitor; F: lysozyme; Amersham Pharmacia Biotech, GE Healthcare Europe GmbH, Munich, Germany)... 123 Figure 3a RP-HPLC of degraded wheat gliadin subfractions extracted from gluten (Sigma-Aldrich, Munich, Germany) after time-dependant treatment with Fusarium graminearum protease

Figure 3b RP-HPLC of degraded wheat glutenin subfractions extracted from gluten (Sigma-Aldrich, Munich, Germany) after time-dependant treatment with Fusarium graminearum protease

Figure 3c Results of RP-HPLC showing the degradation (\% AUC) of wheat gliadin and glutenin subfractions extracted from gluten (Sigma-Aldrich, Munich, Germany) after a 4-h treatment with Fusarium graminearum protease 125 
Figure 4a RP-HPLC of isolated and purified gliadin - peptide formation by Fusarium graminearum protease treatment after different incubation periods; mAbs, microabsorption units

Figure 4b RP-HPLC of isolated and purified gliadin - degradation after time-dependant treatment with Fusarium graminearum protease (Gliadin subfractions: $\omega 5$-Gliadins, $\omega 1,2$-Gliadins, $\alpha$-Gliadins, $\gamma$-Gliadins)

Figure 4c SDS-Page of isolated and purified gliadin - degradation after time-dependant (2-8h) treatment with Fusarium graminearum protease (STD: standard; C: control).. 128 Figure 5a RP-HPLC of isolated and purified glutenin - peptide formation by Fusarium graminearum protease treatment after different incubation periods; mAbs, microabsorption units

Figure 5b RP-HPLC of isolated and purified glutenin - degradation after timedependant treatment with Fusarium graminearum protease (glutenin subfractions: $\omega b-$ Glutenins, HMW-GS, LMW-GS).....

Figure 5c SDS-Page of isolated and purified glutenin - degradation after timedependant (2-8h) treatment with Fusarium graminearum protease (STD: standard; C: control) 130

Figure 5d RP-HPLC of degraded purified glutenins soluble in the gliadin extraction solution B after time-dependant Fusarium graminearum protease treatment; mAbs, micro-absorption units.

Figure 5e SDS-Page of degraded purified glutenins soluble in the gliadin extraction solution B after an 8-h incubation period with Fusarium graminearum protease in comparison to the non-treated control (STD: standard; C: control). .131

Manuskript: Proteome analysis of Fusarium infection in emmer grains (Triticum dicoccum)

Figure 1 Two-dimensional protein gel of emmer grains infected with Fusarium ssp. (12\% SDS-PAGE, IEP range, $\mathrm{pH}$ 3-10, $18 \mathrm{~cm}$, linear strip; Coomassie R250 staining). Changed protein spots are marked with arrows and ID numbered according to Table 2 (ID362 ß-amylase, ID480 globulin-3, ID513 globulin-2, ID 684 glycosyltransferase, ID719 serpin, ID827 $\alpha$-gliadin, ID926 peroxidase I, ID1203 class II chitinase, ID1211 thioredoxin peroxidase, ID1254 thaumatin like protein). .148

Figure 2 In zoomed Coomassie-stained protein spots from 2D gels of naturally and artificially infected emmer which were changed by a factor greater than two. Spot 
numbers according to Table 2 (ID362 ß-amylase, ID480 globulin-3, ID513 globulin-2, ID 684 glycosyltransferase, ID719 serpin, ID827 $\alpha$-gliadin, ID926 peroxidase I, ID1203 class II chitinase, ID1211 thioredoxin peroxidase, ID1254 thaumatin like protein).... 152 Manuskript: Proteome analysis of Fusarium head blight in grains of naked barley (Hordeum vulgare subsp. nudum)

Figure 1 Two-dimensional protein gel of naked barley grains of 12\% NEPHGE SDS PAGE, IEP range, $\mathrm{pH}$ 4-8.5, $18 \mathrm{~cm}$, linear strip; colloidal CBB staining; changed protein spots are marked with arrows and ID numbered according to Tables 2 and 3 (ID12 D-hordein, ID25 RNA polymerase, ID28 Zinc finger protein, ID 30 Disease resistance protein, ID31 Zinc finger protein, ID35 Zinc finger protein, ID107 Transcription factor, ID 489 Endochitinase, ID493 Serpin-Z4, ID494 Serpin-Z type, ID 501 Serpin-Z type, ID 550 Protein synthesis inhibitor, ID 787 Glucose phosphorylase, ID 821 Hypothetical protein). 168

Figure 2 Comparison of selected artificially Fusarium infected 3D and 2D visualised protein spots of naked barley grains in comparison to the control, (regulation of transcription: ID25 RNA polymerase, ID35 Zinc finger protein; defence response: ID 30 Disease resistance protein, ID493 Serpin-Z4) 12\% NEPHGE SDS PAGE, IEP range, pH 4-8.5, $18 \mathrm{~cm}$, linear strip; colloidal CBB staining; ID numbered according to Table 2 173

Figure 3 Comparison of selected artificially Fusarium-infected 2D visualised protein spots of naked barley grains in comparison to controls and in dependence of growing location, (nutrient reservoir: ID12 Zinc finger protein, ID12 D-hordein; defence response: ID 489 Endochitinase; ID 550 Protein synthesis inhibitor) 12\% NEPHGE SDS PAGE, IEP range, $\mathrm{pH}$ 4-8.5, $18 \mathrm{~cm}$, linear strip; colloidal CBB staining, ID 



\section{Tabellenverzeichnis}

\section{Einleitung}

Tab. 1 Vergleich der Gesamt-Proteingehalte (\% Trockenmasse) und Gliadin/Glutenin-

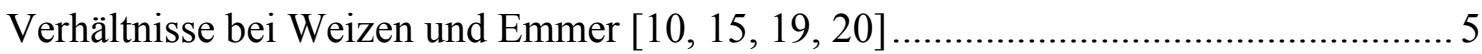

Tab. 2 Einteilung und Charakterisierung der Glutenfraktionen von Weizen in Untereinheiten, spezifische Typen, Lokalisation im Genom, Anzahl an Kopien (Wiederholungen) im Genom, dem Vorkommen von Cysteinresten und Größe [22-28] 7

Tab. 3 Einteilung und Charakterisierung der Speicherproteine von Gerste nach Untereinheiten, Lokalisation im Genom, Anzahl an Kopien (Wiederholungen) im Genom, dem Vorkommen von Cysteinresten und Größe [52, 57, 64-66] ................... 12

Tab. 4 Entwicklungsbedingungen für die Produktion von Makrokonidien und Askosporen bei F. graminearum und F. culmorum nach Champeil et. al [87] 15

Tab. 5 Einteilung von Abwehrmechanismen gegen Fusarium-Infektion in Getreide $[85,87,91,105,106]$

\section{Material und Methoden}

Tab. 6 Standortbedingungen und Düngung in den Jahren 2007 und $2008\left(\mathrm{~N}_{\min }\right.$ bis 90 cm, Stickstoff (N); Kalium (K); Phosphat (P))

Tab. 7 Überblick über verwendete Methoden und deren Beschreibung. 32

Manuskript: Fusarium infection and toxin formation in emmer and naked barley

Table 1 Fungal DNA and deoxynivalenol (DON) and 3-acetyl-deoxynivalenol (3-AcDON) content in grain flour and glume from naturally and artificially infected samples

Table 2 Correlation (r) and significance (p) of correlation between the different parameters in grain and glume in naturally and artificially infected samples

Table 3 Relative proportion (\%) of Fusarium graminearum and Fusarium culmorum DNA, and total toxin (DON + 3-Ac-DON) in emmer glume in comparison to the grain

Publikation: Effects of Fusarium Infection on the Phenolics in Emmer and Naked Barley

Table 1 Total Fusarium toxin content based on DON +3 -Ac-DON concentration in naturally and artificially infected emmer (three cultivars) and naked barley (seven cultivars) grains. 
Table 2 Phenol content in grains of naturally and artificially Fusarium infected emmer (three cultivars) and naked barley (seven cultivars) samples: Fraction 1: methanol soluble $(80 \% \mathrm{MeOH}+1 \%$ acetic acid); Fraction 2: acid-enzyme hydrolysable $\left(\mathrm{H}_{2} \mathrm{SO}_{4} /\right.$ enzyme $)$

Table 3 Phenolic compounds in grains of each one emmer and naked barley cultivar after natural and artificial Fusarium infection as determined by different extraction procedures: Fraction 1: methanol soluble $(80 \% \mathrm{MeOH}+1 \%$ acetic acid); Fraction 2: acid-enzyme hydrolysable $\left(\mathrm{H}_{2} \mathrm{SO}_{4}\right.$ /enzyme)

Table 4 Content of total arabinoxylan monosaccharides in grains of each one emmer and naked barley cultivar after natural and artificial Fusarium infection.....

Publikation: The influence of Fusarium infection and growing location on the quantitative protein composition of (Part I) emmer (Triticum dicoccum)

Table 1a Protein concentration $\left(\mathrm{g} \mathrm{kg}^{-1}\right)$ in naturally and artificially Fusarium infected grain from the emmer cultivar Linie 9-102 and the relative variance between natural and artificial infection (\%) at the locations Sattenhausen and Reinshof as well as the DON and 3-Ac-DON concentration of the naturally and artificially infected grain .78

Table 1b Protein concentration $\left(\mathrm{g} \mathrm{kg}^{-1}\right)$ in naturally and artificially Fusarium infected grain from the emmer cultivar Far-108 + Hein-101 and the relative variance between natural and artificial infection (\%) at the locations Sattenhausen and Reinshof as well as the DON and 3-Ac-DON concentration of the naturally and artificially infected grain.79 Table 1c Protein concentration $\left(\mathrm{g} \mathrm{kg}^{-1}\right)$ in naturally and artificially Fusarium infected grain from the emmer cultivar Klein and the relative variance between natural and artificial infection (\%) at the locations Sattenhausen and Reinshof as well as the DON and 3-Ac-DON concentration of the naturally and artificially infected grain 80

Table 1d Protein concentration $\left(\mathrm{g} \mathrm{kg}^{-1}\right)$ in naturally and artificially Fusarium infected grain from all three emmer cultivars (Far-108 + Hein-101, Klein, Linie 9-102) used in the study and the relative variance between natural and artificial infection (\%) at the locations Sattenhausen and Reinshof as well as the DON and 3-Ac-DON concentration of the naturally and artificially infected grain

Table 1e Protein concentration $\left(\mathrm{g} \mathrm{kg}^{-1}\right)$ in naturally and artificially Fusarium infected grain from the wheat cultivar Amaretto and the relative variance between natural and artificial infection (\%) at the locations Sattenhausen and Reinshof as well as the DON and 3-Ac-DON concentration of the naturally and artificially infected grain .82 
Table 1f Summary of the protein concentration $\left(\mathrm{g} \mathrm{kg}^{-1}\right)$ in naturally and artificially Fusarium infected grain from all three emmer cultivars (Far-108 + Hein-101, Klein, Linie 9-102) and the wheat cultivar Amaretto with the relative variance between natural and artificial infection (\%) at both the Sattenhausen and Reinshof locations as well as the DON and 3-Ac-DON concentration of the naturally and artificially infected grain 83 Table 2 Fusarium Protein Units (FPU) in naturally and artificially Fusarium infected grain flour (summarized data from both locations)

Table 3 Variance of the relative protein concentration between the two locations, Sattenhausen and Reinshof, from the three emmer cultivars (Far-108 + Hein-101, Klein, Linie 9-102) and the wheat cultivar Amaretto dependent on $\mathrm{N}$ supply..... .85

Publikation: The influence of Fusarium infection and growing location on the quantitative protein composition of (Part II) naked barley (Hordeum vulgare nudum)

Table 1a Protein concentration $\left(\mathrm{g} \mathrm{kg}^{-1}\right)$ in naturally and artificially Fusarium infected grain from the naked barley cultivar Frealishe and relative variance between the natural and artificial infections (\%) at the locations Sattenhausen and Reinshof, as well as the DON and 3-Ac-DON concentration of the natural and artificial infections 98

Table 1b Protein concentration $\left(\mathrm{g} \mathrm{kg}^{-1}\right)$ in naturally and artificially Fusarium infected grain from the naked barley cultivar $00 / 900 / 5 \mathrm{~N}$ and relative variance between the natural and artificial infections (\%) at the locations Sattenhausen and Reinshof, as well as the DON and 3-Ac-DON concentrations of the natural and artificial infections

Table 1c Protein concentration $\left(\mathrm{g} \mathrm{kg}^{-1}\right)$ in naturally and artificially Fusarium infected grain from the seven naked barley cultivars $(n=7)$ and relative variance between the natural and artificial infections (\%) at the locations Sattenhausen and Reinshof, as well as the DON and 3-Ac-DON concentration of the natural and artificial infections 100

Table 1d Protein concentration $\left(\mathrm{g} \mathrm{kg}^{-1}\right)$ in naturally and artificially Fusarium infected grain from the summer barley cultivar Barke and relative variance between the natural and artificial infections (\%) at the locations Sattenhausen and Reinshof, as well as the DON and 3-Ac-DON concentration of the natural and artificial infections 101

Table 1e Summary of protein concentration $\left(\mathrm{g} \mathrm{kg}^{-1}\right)$ in naturally and artificially Fusarium infected grain from the seven naked barley cultivars and the summer barley cultivar Barke with relative variance between the natural and artificial infections (\%) at 
both locations Sattenhausen and Reinshof, as well as the DON and 3-Ac-DON concentration of the natural and artificial infections 102

Table 2 Variance of relative protein concentration between the two locations, Sattenhausen and Reinshof, of seven naked barley cultivars and the summer barley cultivar Barke with respect to the $\mathrm{N}$ supply

\section{Manuskript: In vitro-degradation of wheat gluten fractions by Fusarium graminearum proteases}

Table $1 \mathrm{C} / \mathrm{N}$ ratio and protein content of the purified gluten fractions - gliadin and glutenin after isolation using the factor 5.7 for calculation as for the wheat gluten (ICC No. 105/2)

Table 2 Peptide formation from isolated gliadin (Fig. 4a), glutenin (Fig. 5a) and the amounts of degraded glutenins soluble in the gliadin extraction solution B (Fig. 5d) after time-dependent Fusarium graminearum protease treatment

Table 3 The amount of gliadin (Fig.4b) and glutenin (Fig. 5b) sub-types remaining (peak area in \%) after Fusarium graminearum protease treatment after different incubation times in comparison to the undigested protein control (100\%). 128

\section{Manuskript: Proteome analysis of Fusarium infection in emmer grains (Triticum dicoccum)}

Table 1 DON plus 3-Ac-DON concentrations as toxin ( $\mathrm{mg} \mathrm{kg}^{-1}$ whole-grain flour) of naturally and artificially infected emmer grains from the locations Sattenhausen and Reinshof. Carbon (C), nitrogen (N) and crude protein content of naturally and artificially infected emmer grains (protein, factor, 5.7; ICC No. 105/2) and Fusarium graminearum (protein, factor 6.25; ICC No. 105/2)

Table 2 Compilation of information about ten proteins changed in abundance upon infection with Fusarium spp. in emmer grains. Ratio (relative units) based on differences in proteins from naturally and artificially infected grains as detected by twodimensional gel electrophoresis (see Materials and Methods). Identification of proteins by (a) sequence coverage was 100\%; Mascot score: identification using nanoLCMS/MS de-novo-synthesis and with MALDI-TOF-MS (see Materials and Methods). Spot ID see Figure 1 .150 
Manuskript: Proteome analysis of Fusarium head blight in grains of naked barley (Hordeum vulgare subsp. nudum)

Table 1 DON concentrations ( $\mathrm{mg} \mathrm{kg}^{-1}$ whole grain flour), carbon $(\mathrm{C})$, nitrogen $(\mathrm{N})$ and crude protein content of naturally and artificially infected naked barley grains (cultivar ZFS) from the locations Sattenhausen and Reinshof. (protein, factor, 6.25; ICC No. $105 / 2)$

Table 2 Compilation of information about eleven proteins changed in abundance upon infection with Fusarium spp. in naked barley grains at the locations Sattenhausen and Reinshof. Ratio (relative units) between naturally and artificially infected proteins detected by two-dimensional gel electrophoresis (see Materials and methods). Identification of proteins by Mascot score with MALDI TOF MS (see Material and methods). Spot ID see Figure $1(\mathrm{p}=$ significance at $\mathrm{p}<0.05 ; \mathrm{MV}=$ mean value; $\mathrm{SD}=$ standard deviation)

Table 3 Compilation of information about three proteins changed in abundance according to growing location in naked barley grains. Ratio (relative Units) between changed proteins depending on the location detected by two-dimensional gel electrophoresis (see Materials and methods). Identification of proteins by Mascot score: identification using nanoLC-MS/MS de-novo-synthesis and MALDI TOF MS, (see Material and methods). Spot ID see Figure $1(\mathrm{p}=$ significance at $\mathrm{p}<0.05 ; \varnothing=$ mean of both naturally and artificially infected samples at one location; $\mathrm{MV}=$ mean value; $\mathrm{SD}=$ standard deviation) 



\section{Vorwort}

Emmer (Triticum dicoccum) und Nacktgerste (Hordum vulgare ssp. nudum), zwei Kulturarten, die vor allem im ökologischen Landbau angebaut werden, wurden in der vorliegenden Arbeit hinsichtlich ihrer Anfälligkeit gegenüber Fusarium-Befall untersucht. Schwerpunkt der Untersuchungen war der Einfluss einer natürlichen und einer künstlichen Fusarium-Infektion auf ausgewählte Inhaltsstoffe im Korn dieser Arten. Im Gegensatz zu Weizen sind die Auswirkungen einer Fusarium-Infektion auf die Korninhaltsstoffe der beiden Arten wenig oder gar nicht untersucht.

Die vorliegende Arbeit entstand im Rahmen des Teilprojektes 5 des Forschungsverbunds Agrar- und Ernährungswissenschaften Niedersachsen (FAEN) zum Thema „Qualitätsgerechte Pflanzenproduktion unter veränderten Rahmenbedingungen: Mykotoxine im Kontext von Produktion, Qualität und Verarbeitung“. Die Förderung erfolgte durch das Niedersächsische Ministerium für Wissenschaft und Kultur. Kooperationspartner im Projekt waren die Züchter Dr. KarlJosef Müller, Getreidezüchtungsforschung Darzau; Eckard Irion, Verein für Pflanzenzucht Hof Grub e.V.; Herr Dr. Claus Einfeldt, Saatzucht Ackermann; HansWerner Klein, UGB Gesundheitsförderung; als weitere Forschungseinrichtungen: Max Rubner-Institut, Institut für Sicherheit und Qualität bei Getreide, Schützenberg 12 , 32756 Detmold; Universität Potsdam, Institut für Ernährungswissenschaft, Abteilung Lebensmittelchemie, Arthur-Scheunert-Allee 114-116, 14558 Nuthetal; Deutsche Forschungsanstalt für Lebensmittelchemie, Lichtenbergstr. 4, 85748 Garching und die Christian-Albrechts-Universität $\mathrm{zu}$ Kiel, Institut für Pflanzenernährung und Bodenkunde, Hermann-Rodewald-Str. 2, 24118 Kiel. 



\section{Einleitung}

\subsection{Emmer (Triticum turgidum L. ssp. dicoccum)}

\section{Allgemeine Beschreibung}

Die Familie der Süßgräser (Poaceae), zu der auch der Emmer gehört, hat Vertreter auf allen Kontinenten (außer Antarktis) und spielt im Ökosystem der afrikanischen und südamerikanischen Savanne eine vorherrschende Rolle [1]. Zu den Süßgräsern zählen mehr als 10.000 Arten, darunter die bekannten Getreidearten wie Weizen, Reis, Mais, Roggen und Gerste, deren gemeinsamer Vorfahre vor etwa 10 Millionen Jahren lebte, wobei erste Vorfahren der Gräser bereits vor 55 bis 70 Millionen Jahren (Abb. 1, 2, 3) auftraten [1].

Emmer, eine alte Weizenart, kommt als Wildform (Triticum turgidum ssp. dicoccoides) und als Kulturform (Triticum turgidum L. ssp. dicoccum) vor [2, 3]. Zwischen den verschiedenen Formen unterscheidet man Winter- und Sommerformen [4]. Die Domestikation von Emmer im fruchtbaren Halbmond (Abb. 1), einer Region im östlichen Mittelmeerraum, die Teile der Länder Türkei, Israel, Syrien, Libanon, Ägypten, Iran und Irak umfasst, war die Voraussetzung für die Entwicklung des heute kultivierten Brotweizens (Triticum aestivum) und Hartweizen (Triticum durum) [2, 3, 5].

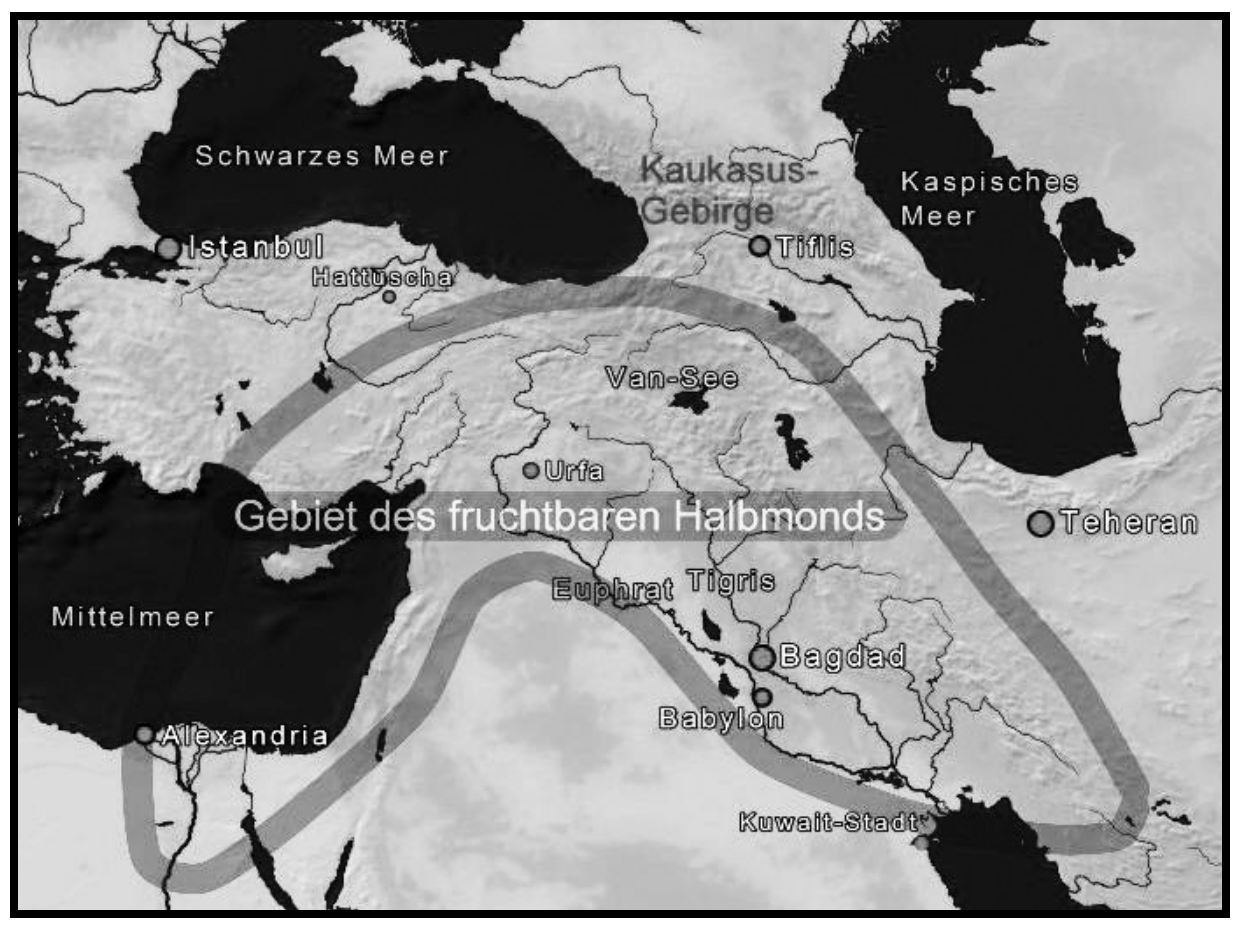

Abb. 1 Gebiet des fruchtbaren Halbmonds im östlichen Mittelmeer [6] 
Die genetische Verwandtschaft zwischen der Wild- und Kulturform des Emmers weist auf den Südosten der Türkei als Ausgangspunkt der Domestikation hin [2, 3, 5]. Von dort breitete sich der Anbau über Asien, Europa und Afrika aus [2]. Die Domestikation hatte genetisch bedingte physikalische und physiologische Veränderungen der Pflanze zur Folge, welche das Ergebnis des menschlichen Einflusses und dessen kultureller Entwicklung sind [7]. Bereits kurze Zeit, nachdem der Mensch im Nahen Osten sesshaft wurde -vor mehr als 13.000 Jahren- begann der lange Prozess der Getreidedomestikation. Eindeutige Hinweise, dass Emmer durch den Menschen kultiviert wurde, stammen von vor 10.000 Jahren. [7].

Emmer besitzt einen tetraploiden Chromosomensatz $(2 n=4 x=28$; AABB). Heute geht man davon aus, dass Emmer durch Kreuzung (Hybridisierung) aus wildem Einkorn (Triticum urartu, A-Genom) und einer nah mit dem Wildgras Aegilops speltoides verwandten Art (B-Genom) entstanden ist [8]. Aus dem tetraploiden wilden Emmer (Triticum turgidum ssp. dicoccoides) entstand nach Einkreuzung einer weiteren unbekannten Art, die mit dem Ziegengras (Aegilops tauschii) verwandt ist und als Spender des D-Genoms gilt, sowie durch weitere Mutationen und Auslese der heute bekannte hexaploide Kulturweizen $(2 n=6 x=42$, AABBDD) $[5,8]$.

\section{Verbreitung, Anbaufläche, Ertrag}

Der Anbau von Emmer ist heute für die landwirtschaftliche Praxis von untergeordneter Bedeutung [9]. Bis in die 1960er Jahre war der Emmeranbau im Mittelmeerraum weit verbreitet, verringerte sich dann aber drastisch zu Gunsten anderer Kulturen [10]. Heute wird Emmer in größerem Umfang noch in Äthiopien, Indien (50.000 ha in 2005) und Italien (2000 ha konstant) angebaut [11-13]. Im deutschsprachigen Raum gibt es hauptsächlich in Süddeutschland, Österreich und der Schweiz regional begrenzte Anbauaktivitäten, wobei der ökologische Anbau im Vordergrund steht, genaue Anbauflächen jedoch nicht bekannt sind [9, 12, 14]. Die Erträge beim Emmer betragen etwa 30\% der Erträge moderner Weizensorten . Die beschriebenen Erträge reichen von 20 bis $68 \mathrm{dt} \mathrm{ha}^{-1}[4,9,10,15,16]$ wobei in der Praxis durchschnittliche Erträge um 25 $\mathrm{dt} \mathrm{ha}{ }^{-1}$ Rohware mit Spelzen erreicht werden [4, 14, 15]. Der Anteil der Spelze am Korn beträgt in der Regel zwischen $25-40 \%$, so dass sich der Kornertrag durch das Entspelzen weiter verringert [17]. Bezüglich seiner Standort- und Nährstoffansprüche gilt Emmer als wenig anspruchsvoll und kann deshalb auch bei geringer Bodenfruchtbarkeit und unter kühleren Klimabedingungen angebaut werden [10, 14, 17]. Nachteilig für den 
Anbau von Emmer sind seine Lagerneigung und die Spindelbrüchigkeit während der Ernte $[4,15,17]$.
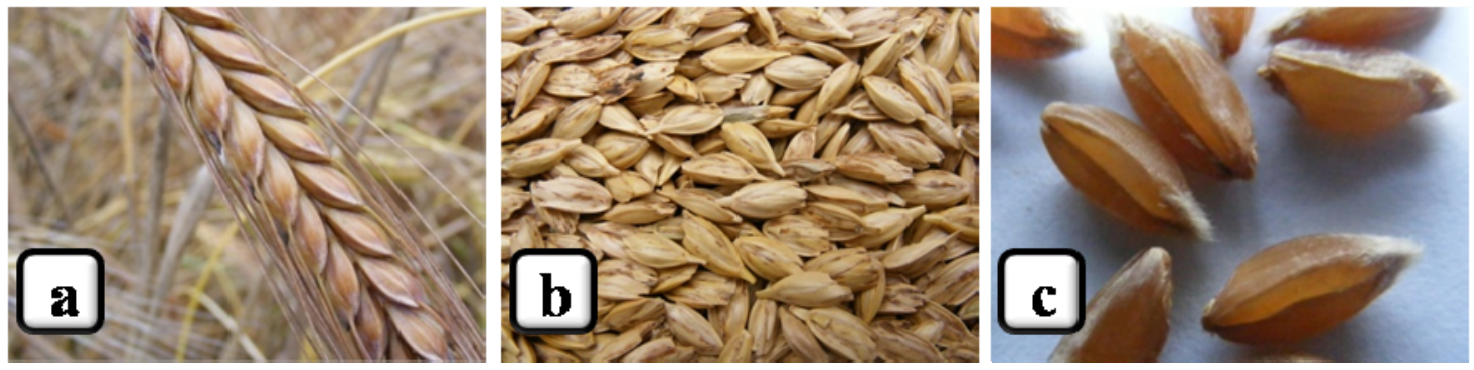

Abb. 2 Emmer-Ähre [BBCH* 89] (a), reife geerntete und gereinigte Vesen [BBCH 99] (b), entspelzte Körner [BBCH 99] (c), [Fotos Eggert 2007, 2008] * BBCH-Skala: Entwicklungsstadien mono- und dikotyler Pflanzen (Uwe Meier, Biologische Bundesanstalt für Land- und Forstwirtschaft, 2001 nach Hack et al. 1992)

\section{Verwendung}

Verwendung findet Emmer mit seinem kräftigen herzhaften Geschmack als Brotgetreide und zur Herstellung von Nudeln und Bier [14, 18]. Für die Herstellung von Brot spielt vor allem die Qualität der glutenbildenden Proteine eine entscheidende Rolle [5]. Obwohl diese als unbefriedigend gilt, zeigen Praxiserfahrungen, dass sich aus Emmer ausgezeichnete Gebäcke herstellen lassen [15]. Emmer weist im Vergleich zu Weizen eine andere Zusammensetzung der glutenbildenden Proteinfraktionen Gliadin und Glutenin auf (Tab. 1), was unterschiedliche Backeigenschaften wie das Gashaltevolumen u.a. erklärt [19]. Gliadin kommt zwar in ähnlichen Quantitäten wie im Weizen vor, der Gluteningehalt beträgt dagegen nur etwa ein Drittel [19]. Weitere Verwendung findet Emmer als Vollkornmehl in der Herstellung von Waffeln, Mürbeteig und Hefegebäck. In der Vergangenheit wurden aus Emmer hergestellte Graupen denen der Gerste häufig vorgezogen. Die Vesen (Vese: 2 Körner mit Spelzen) des Emmers (Abb. 2) wurden als Haferersatz an Pferde verfüttert [5].

Tab. 1 Vergleich der Gesamt-Proteingehalte (\% Trockenmasse) und Gliadin/GluteninVerhältnisse bei Weizen und Emmer [10, 15, 19, 20]

\begin{tabular}{lcc}
\hline Parameter & $\begin{array}{c}\text { Weizen } \\
\text { (Triticum aestivum) }\end{array}$ & $\begin{array}{c}\text { Emmer } \\
\text { (Triticum dicoccum) }\end{array}$ \\
\hline Gesamtprotein & $12-14$ & $10-19$ \\
Gliadin/Glutenin-Verhältnis & $1.8-2.5$ & $3.4-6.6$ \\
\hline
\end{tabular}




\section{Inhaltsstoffe des Korns}

Die im Emmer zu findenden Albumine und Globuline spielen hautsächlich im Stoffwechsel der Pflanze und als Strukturproteine eine Rolle [21]. Zu ihnen zählen Enzyme, Enzyminhibitoren und Proteine, die in der Stressantwort der Pflanze bei Befall mit Krankheitserregern eine Rolle spielen [21]. Unterschiede zum Weizen finden sich hier auf Grund des nicht vorhandenen D-Genoms bei Emmer [20]. Das D-Genom enthält funktionelle Proteine wie Hitze-Schock-Proteine und $\alpha$-Amylase-Inhibitoren, die im Emmer auf Grund des fehlenden Chromosomensatzes nicht oder in geringeren sowie veränderten Quantitäten vorkommen [20]. Die Speicherproteine in Weizen (Tab. 2) befinden sich auf dem kurzen Arm des Chromosoms 1 ( $\gamma$-Gliadin-Familie, $\omega$-Gliadine, LMW-Glutenin-Familie-Kopien), auf dem langen Arm von Chromosom 1 (HMWGlutenin-Familie) und auf dem kurzen Arm von Chromosom 6 ( $\alpha$-Gliadin-Familie) [2224]. Da bei Emmer das D-Genom nicht vorhanden ist, liegt eine geringere Anzahl an Kopien als im Weizen vor (Tab. 2), was zu den im Abschnitt „Verwendung“ beschriebenen veränderten Backeigenschaften beiträgt.

Der Stärkegehalt im Weizenkorn liegt bei ca. 62-75\%, der von Emmer im unteren Bereich dieser Spannweite bei etwa 60\% [29, 30]. Emmer weist im Gegensatz zu Weizen mit Ausnahme von Calcium etwas höhere Mineralstoffgehalte auf (Emmer/Weizen: Zn: 60/31 mg kg ${ }^{-1}, \mathrm{Mg}: 1,7 / 1,5 \mathrm{~g} \mathrm{~kg}^{-1}$, Fe: $41 / 38 \mathrm{mg} \mathrm{kg}^{-1}$, Ca: 36/44 $\left.\mathrm{mg} \mathrm{kg}^{-1}\right)[4,15]$. Weitere Inhaltsstoffe im Emmer sind Ballaststoffe wie Nicht-StärkePolysaccharide (Arabinoxylane), die über Phenole quervernetzt sind und auch mit anderen Korninhaltsstoffen interagieren [31]. Darüber hinaus finden sich im Korn geringen Mengen Glucane sowie Carotinoide, Vitamine (insbesondere Tocopherole) und Lipide [15, 33-35]. Ein Vergleich von Emmer mit Weizen, ist auf Grund der schlechten Datenlage dieser Verbindungen im Emmer nicht möglich. 
Tab. 2 Einteilung und Charakterisierung der Glutenfraktionen von Weizen in Untereinheiten, spezifische Typen, Lokalisation im Genom, Anzahl an Kopien (Wiederholungen) im Genom, dem Vorkommen von Cysteinresten und Größe [22-28]

\begin{tabular}{|c|c|c|c|c|c|c|c|}
\hline Glutenfraktion & Untereinheiten & Chromosom & Gen-Loci & Kopien & \multicolumn{2}{|c|}{ Cysteinreste } & Größe (kDa) \\
\hline \multirow[t]{3}{*}{ Gliadin } & $\omega$ & kurzer Arm ,Chromosom 1 & Gli-3 & $15-18$ & - & - & $40-66$ \\
\hline & $a / ß$ & kurzer Arm, Chromosome 6 & Gli-2 & 150 & 6 & Intramolekular & $30-41$ \\
\hline & $\gamma$ & $\begin{array}{c}\text { kurzer Arm, Chromosom } 1 \\
\text { (zum Teil kurzer Arm, Chromosom 6) }\end{array}$ & Gli-1 & $16-39$ & 8 & Intramolekular & $30-45$ \\
\hline \multirow[t]{6}{*}{ Glutenin } & LMW & kurzer Arm, Chromosom 1 & Glu-3 & $30-40$ & $2 n$ & Intermolekular & $55-77$ \\
\hline & & - & - & - & - & Intermolekular & $30-40$ \\
\hline & & - & - & - & - & Intermolekular & $42-51$ \\
\hline & HMW & langer Arm, Chromosom 1 & Glu-1 & 1 & 4 & Intermolekular & $80-150$ \\
\hline & & - & - & 1 & $6-7$ & Intermolekular & $67-88$ \\
\hline & $\omega \mathrm{b}$ & $\begin{array}{l}\text { kurzer Arm, Chromosom } 1 \\
\text { (nur D-Genom) }\end{array}$ & Glu-3 & - & - & - & - \\
\hline
\end{tabular}




\section{Gesundheitliche Aspekte}

Besondere Beachtung für die Gesundheit des Menschen finden vor allem die Glutenproteine. Zöliakie ist eine permanente Störung des Gastrointestinaltraktes, die auf der Intoleranz gegenüber bestimmten Glutenproteinen beruht [36]. Eine genetisch determinierte spezifische Immunreaktion gegenüber dem Glutenantigen führt zur Zerstörung der Darmschleimhaut [37]. Folgen dieser Zerstörung sind Entzündungen des Magen-Darm-Traktes und eine krankhaft verringerte Nährstoffaufnahme [38]. Neben Weizenproteinen sind auch Proteine der verwandten Arten Gerste, Roggen und Hafer für Menschen mit Zöliakie zu meiden [39]. Positive Eigenschaften für die Gesundheit des Menschen werden dagegen den in der Aleuronschicht von Emmer und Weizen enthaltenen Nicht-Stärke-Polysacchariden zugeschrieben. Die Bildung von Folgeprodukten (Butyrate) nach Induzierung der Blinddarm-ß-Glucoronidase soll schützend wirken und Dickdarmgeschwüre verhindern [40].

\subsection{Nacktgerste (Hordeum vulgare ssp. nudum)}

\section{Allgemeine Beschreibung}

Nacktgerste (Hordeum vulgare ssp. nudum) und die hauptsächlich angebaute Kulturgerste (Hodeum vulgare) haben im Gegensatz zu Emmer und Weizen nur eine wild wachsende Ausgangsform als Vorgänger (Hordeum spontanum) [41, 42]. Die nackte Form unterscheidet sich von der Kulturgerste dabei nur durch die rezessive Form eines einzigen Gens [41]. Morphologisch entspricht die Varietät Nacktgerste der bespelzten Kulturform, bis auf die nicht mit dem Korn verwachsenen Spelzen [43]. Gerste kommt in ihrer morphologischen Ausprägung als zweizeilige (Hordeum vulgare ssp. distichum) oder sechszeilige (Hordeum vulgare ssp. vulgare) Form vor, die offen (chasmogamous) oder geschlossen (cleistogamous) blühen kann [44, 45]. Wie Emmer wurde auch Gerste im Bereich des fruchtbaren Halbmonds (Abb. 1) vor ca. 10.000 Jahren domestiziert [2, 41, 42, 44]. Nacktgerste, die dort zusammen mit Emmer vermischt in Gräbern gefunden wurde, ist aus der Literatur auch als „Mumienweizen“ bekannt [41]. Der südliche Teil des fruchtbaren Halbmondes (Israel-Jordanien) ist mit großer Wahrscheinlichkeit das Gebiet, in dem wilde Gerste domestiziert wurde und von wo aus sie über den Iran bis in den Himalaya gelangte [42]. 


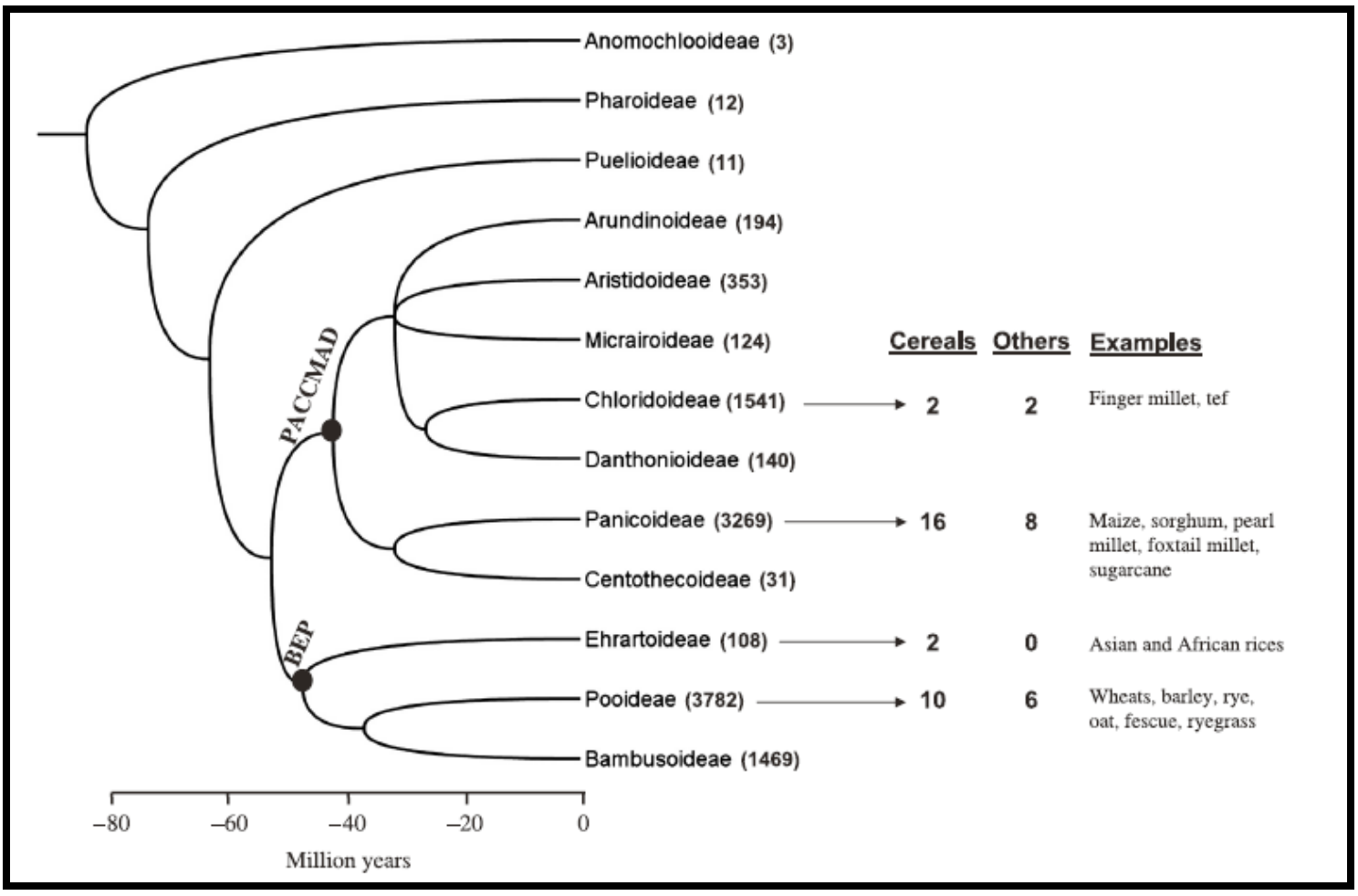

Abb. 3 Phylogenese der Gräser [44]

Im Gegensatz zu Emmer und Weizen, die durch Kreuzung verschiedener Arten entstanden sind, ist Gerste monophyletisch [5, 42]. Die Art besitzt einen diploiden Chromosomensatz $(2 \mathrm{n}=14)$ und eine Genomgröße von ca. 5000 Megabasen $(\mathrm{Mb})$. Im Vergleich dazu besitzt hexaploider Weizen $(2 \mathrm{n}=42)$ eine Genomgröße von ca. 16.000 $\mathrm{Mb}$ [46-48]. Wie Emmer und Weizen gehört auch Gerste zur Familie der Süßgräser (Poaceae) (Abb. 3) mit der bereits beschriebenen evolutionären Abstammung [7, 44]. Auf Grund der Herkunft werden in der Abstammung zwei Gruppen, d.h. eine für den Raum Europa, Nordafrika und den nahen Osten und eine asiatische Gruppe, die im iranischen Plateau aus den Vorgängerformen von Nordafrika entstanden ist, unterschieden [49]. Außerdem ist eine weitere Differenzierung durch die nackte Kulturform und zweizeilige sowie sechszeilige Gerste in den beiden Gruppen möglich [49].

\section{Verbreitung, Anbaufläche, Ertrag}

Nacktgerste (Abb. 4) wird heute hauptsächlich in Kanada (Jahresproduktion 1998: 800.000 t, 300.000 - 350.000 ha), den USA (Jahresproduktion: 5000 t), Australien und im geringen Umfang in einigen europäischen Ländern sowie in Afrika angebaut [50]. Bezogen auf die weltweite Produktion von Gerste, die laut FAO (2008) bei 158 Mio. $t$ lag, nimmt die Nacktgerste einen Anteil von etwa $0.5 \%$ ein [51]. Verwendet man den Ertrag und die Anbaufläche von Kanada als Beispiel für den Hektarertrag, den man mit 
Nacktgerste erzielen kann, errechnen sich $23-27 \mathrm{dt} \mathrm{ha}^{-1}$ für das Jahr 1998. Im Vergleich dazu werden mit Wintergerste (50-90 dt ha $\left.{ }^{-1}\right)$ sowie mit Sommergerste (40-65 $\mathrm{dt} \mathrm{ha}^{-1}$ ) deutlich höhere Erträge erzielt [51]. Vorteilhaft, auch unter eher schwierigen Anbaubedingungen, sind die hohe Stresstoleranz und die kurze Wachstumsphase von Nacktgerste [52]. Für Deutschland finden sich in der Literatur keine Informationen zu Anbaufläche oder Erträgen, es finden aber Züchtung und Verkauf für den ökologischen Anbau statt [53].
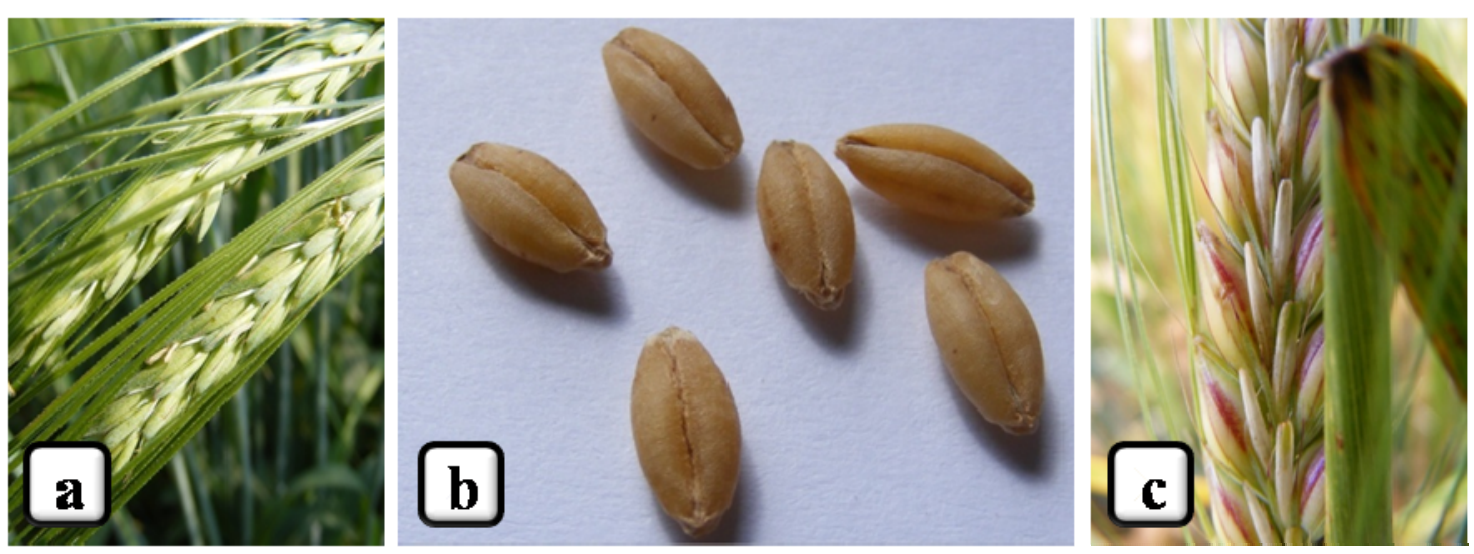

Abb. 4 Nacktgerste [BBCH 65] (a), reife geerntete und gereinigte Körner [BBCH 99] (b), gefärbte Nacktgerste [BBCH 75] (c) [Fotos Eggert 2007, 2008]

\section{Verwendung}

Verwendet wird Nacktgerste gemahlen, gedämpft, gekocht, gebacken, gepresst, geröstet, zu Flocken und Graupen verarbeitet, als Grütze und in gekeimter Form [50, 54]. In einer Mehlmischung zur Brotherstellung kann der Anteil an Nacktgerste bis zu $30 \%$ betragen, ohne die Backeigenschaften zu beeinträchtigen [55]. In Japan findet sie als Tee, fermentiert in alkoholischen Getränken wie Sochu und Miso und als Reisersatz Verwendung $[50,56]$. Weiterhin wird Nacktgerste, ebenso wie Gerste, als Braugetreide und für die Produktion von Biotreibstoff eingesetzt [57]. Als Malz wird Nacktgerste ebenfalls zur Herstellung von Whisky genutzt und bietet hier Vorteile gegenüber der bespelzten Kulturgerste. Da weniger Nebenprodukte anfallen, können der Verbrauch von Wasser reduziert und sich die Zeit des Mälzens verkürzt werden, was eine Prozessoptimierung bewirkt [58]. Neben den herkömmlichen Gerstensorten gibt es sogenannte waxy Gerstesorten, deren Stärkeanteil zu 95\% aus Amylopektin besteht, was eine 2,5 fach erhöhte Wasseraufnahme und eine gesteigerte Gefrier-Tau-Stabilität der Produkte bewirkt. Diese Eigenschaften werden besonders im Tiefkühlsektor, in der Teigwarenherstellung sowie in der stärkeverarbeitenden Industrie genutzt [50, 53, 59].

\section{Inhaltsstoffe des Korns}


In Gerste finden sich neben den Speicherproteinen des Endosperms, die ein Schwerpunkt der vorliegenden Arbeit darstellen, weitere in schwachen Salzlösungen lösliche Proteine, die $\mathrm{zu}$ den Albuminen und Globulinen gehören [60]. Zu dieser Proteinfraktion zählen sogenannte „housekeeping“ Enzyme, die im Metabolismus der Zelle eine Rolle spielen, Chaperone, Abwehrproteine wie Enzyminhibitoren, Chitinasen, stressabhängige und das Wachstum von Mikroorganismen hemmende Proteine [60-62]. In Abhängigkeit vom Reifegrad des Getreides sind einige dieser Proteine eher in der frühen Kornfüllungsphase (Bsp. Ascorbatperoxidase) zu finden, andere dagegen in der späten Phase der Kornfüllung (Bsp. Serin-Protease-Inhibitoren), weitere durchgehend über den gesamten Reifungsprozess (Bsp. cytosolische Malatdehydrogenase) [60]. Die Speicherproteine der Gerste werden nach ihrer Löslichkeit wie bei Emmer und Weizen in eine Prolaminfraktion, die in Hordeine in $\gamma$ und C-Hordeine unterteilt wird, und eine Gluteninfraktion, die in Hordenine in D- und B-Hordenine unterteilt wird, (Tab. 3) unterschieden [63, 64]. Insgesamt zeigt Nacktgerste einen Proteingehalt von 12 bis 16\% ähnlich dem von Wintergerste [50,56], der von Braugerste liegt unter 10\% [ 67].

Nacktgerste enthält ca. $60 \%$ Stärke [50], die bespelzte Gerste besitzt mit ca. 50-58\% einen etwas geringeren Stärkeanteil, davon sind etwa 60-70\% Amylopektin und ca. 3040\% Amylose [ 67]. Bezüglich der Gehalte an weiteren Inhaltsstoffen in Nacktgerste gibt es kaum Information. Der Mineralstoffgehalt von bespelzter Gerste liegt mit 22,5 g $\mathrm{kg}^{-1}$ etwas höher als der von Weizen mit $18 \mathrm{~g} \mathrm{~kg}^{-1}$. Im Vergleich zu Emmer und Weizen findet man in der Gerste aber sehr hohe Ca-Gehalte $\left(380 \mathrm{mg} \mathrm{kg}^{-1}\right)$, während die Gehalte an $\mathrm{Zn}\left(31 \mathrm{mg} \mathrm{kg}^{-1}\right), \mathrm{Mg}\left(1,14 \mathrm{~g} \mathrm{~kg}^{-1}\right)$ und $\mathrm{Fe}\left(28 \mathrm{mg} \mathrm{kg}^{-1}\right)$ etwas geringer sind [68]. Bespelzte Gerste enthält ebenfalls Nicht-Stärke-Polysaccharide sowie phenolische Verbindungen und Vitamine [69, 70]. Daneben befinden sich in Gerste phenolische Verbindungen, die in Weizen nicht vorkommen, wie Proanthocyanidine und in gefärbten Gerstesorten Anthocyane, die aus ernährungsphysiologischer Sicht interessant sind $[71,72]$. 
Tab. 3 Einteilung und Charakterisierung der Speicherproteine von Gerste nach Untereinheiten, Lokalisation im Genom, Anzahl an Kopien (Wiederholungen) im Genom, dem Vorkommen von Cysteinresten und Größe [52, 57, 64-66]

\begin{tabular}{|c|c|c|c|c|c|c|c|}
\hline Fraktion & Untereinheiten & Chromosom & Gen-Loci & Kopien & \multicolumn{2}{|c|}{ Cysteinreste (mol \%) } & Größe (kDa) \\
\hline \multirow[t]{2}{*}{ Hordein } & C & kurzer Arm (1HS), Chromosom 5 & Hor-1 & $\begin{array}{l}\text { mehrere } \\
\text { heterogen }\end{array}$ & S-arm & 0.0 & $36-72$ \\
\hline & $\gamma(\mathrm{A})$ & - & - & - & S-reich & 3.5 & $<20$ \\
\hline \multirow[t]{2}{*}{ Hodenin } & D & langer Arm (1HL), Chromosom 5 & Hor-3 & $\geq 2$ & S-arm & 1.5 & $100-105$ \\
\hline & B & $\begin{array}{l}\text { kurzer Arm (1HS),Chromosom 5; } \\
\text { distal zu Hor-1 }\end{array}$ & Hor-2 & $\geq 6$ & S-reich & 2.9 & $28-45$ \\
\hline
\end{tabular}




\section{Gesundheitliche Aspekte}

Wie bereits für Weizen und Emmer erläutert, können auch die Speicherproteine der Gerste bei Zöliakie zur Zerstörung der Darmschleimhaut führen, weshalb diese Produkte für Menschen mit einer Getreideproteinintoleranz zu meiden sind [36-39]. Nacktgerste und Gerste enthalten im Vergleich zu Weizen und Emmer einen höheren Anteil an $\beta-G l u c a n e n ~[50,67]$. Nacktgerste weist Gehalte von 5-8 \% auf [50], bespelzte Gerste Gehalte von 3,5-5\% [67]. Der hohe ß-Glucan-Gehalt von Gerste wird in Verbindung mit gesundheitlichen Aspekten, wie einem reduzierten Blutcholesterolspiegel, verringertem Blutglucosespiegel und antikarzinogener Wirkung gebracht, die auf der Bildung von Folgeprodukten im Magen-Darm-Trakt beruhen [40, 50]. Weitere Inhaltsstoffe, die den Wert von Gerstenprodukten für die menschliche Gesundheit beschreiben, sind lösliche phenolische Verbindungen der Flavonoid-Gruppe wie Proanthocyanidine und in blau oder lila gefärbten Varietäten auch Anthocyane [71, 73]. Verbindungen, wie Catechin und dessen Derivate, die oligomeren Proanthocanidine, zeigen protektive Effekte gegen Krankheitserreger, besitzen antimikrobielle Aktivität, werden als Radikalfänger beschrieben und können u.a. mit Enzymen interagieren und deren Aktivität beeinflussen [72, 74, 75].

\subsection{Fusarium-Infektion an Getreide}

\section{Einführung}

Pilzinfektionen führen weltweit $\mathrm{zu}$ Krankheiten an Pflanzen, die Ernteverluste an Kulturpflanzen verursachen und deren Sekundärprodukte toxisch für Mensch und Tier sein können [76-78]. Pilzarten der Gattung Fusarium führen an Weizenähren zu partieller Taubährigkeit, auch als „Fusarium head blight“ (FHB) bekannt, und zu Schmachtkörnern im Erntegut [78-80]. In Europa zählen F. graminearum Schwabe (teleomorph: Giberella zeae (Schwein.) Petch) und F. culmorum (W. G. Smith) Sacc. zu den am häufigsten an Weizen auftretenden Fusarium -Arten [78, 81]. Beide Arten sind Produzenten verschiedener Sekundärmetabolite, zu denen Toxine aus der Gruppe der Trichothecene, darunter Deoxynivalnol (DON), und Zearalenon (ZEA), ein Xenoöstrogen, gehören [82]. Die Kontamination von Nahrungs- und Futtermitteln mit Fusarium-Toxinen und die daraus entstehenden gesundheitlichen Risiken für Mensch und Tier führten deshalb in der EU zur Einführung von Grenzwerten für DON und ZEA in Getreide und Getreideerzeugnissen. [(EG) Nr. 856/2005. 2006; (EG) Nr. 576/2006. 2006]. 


\section{Epidemiologie von Fusarium}

Zum ersten Mal erwähnt wurde FHB bereits 1884 in England, die häufigsten Berichte stammen jedoch aus den USA [78, 83]. Seitdem wurde FHB an verschiedenen Getreidearten, hauptsächlich aber an Weizen, Gerste und Mais weltweit nachgewiesen und dokumentiert [83]. Für die Landwirtschaft bedeutsame Fusarium-Spezies wachsen und überwintern im Boden auf Pflanzenresten wie Stängeln und Wurzeln (saprophytische Phase), die auf dem Feld verbleiben [78, 81, 84, 85]. Das saprophytische Myzel auf Stoppelresten, Chlamydosporen (F. culmorum), Perithezien (F. graminearum) und Makrokonidien bilden das Inokulum für eine Infektion in der neuen Vegetationsperiode [78, 81, 84]. Warm-feuchte Witterungsbedingungen während der Getreideblüte begünstigen die Konidienbildung (asexuell) und die Entwicklung von Askosporen in den Perithezien (sexuell, pathogene Phase) (Tab. 4) [78, 81, 83, 85]. Wind, Regen und Insekten führen dann zur Verbreitung der Sporen und zur Infektion der Wirtspflanzen [83]. Die Pilzsporen entwickeln sich auf der Oberfläche von Blüten und Spelzen (initiale Phase) [83, 85]. Die Hyphen des Pilzes wachsen entweder passiv über die Stomata (Spaltöffnungen) oder aktiv ins Gewebe, wobei auch ein Wachstum zwischen Kutikula und Epidermis der Hüll- und Deckspelze beobachtet werden kann [83, 85]. Aktives Wachstum setzt dabei die Bildung von Enzymen voraus, die die Kutikula, Zellwand und Zellmembran abbauen können, um das Einwachsen von Fusarium in die Zellen des Korns zu gewährleisten [85, 86]. Erst dann beginnt der Pilz mit der Freisetzung von Toxinen in das Gewebe der Wirtspflanze [85]. 
Tab. 4 Entwicklungsbedingungen für die Produktion von Makrokonidien und Askosporen bei F. graminearum und F. culmorum nach Champeil et. al [87]

\begin{tabular}{|c|c|c|c|c|c|}
\hline \multirow[t]{2}{*}{ Fusarium -Art } & \multirow[t]{2}{*}{ Stadium } & \multicolumn{2}{|c|}{ Temperatur $\left({ }^{\circ} \mathrm{C}\right)$} & \multirow[t]{2}{*}{ Druck (Bar) } & \multirow{2}{*}{$\begin{array}{l}\text { Begünstigende } \\
\text { Faktoren }\end{array}$} \\
\hline & & Toleranz & Optimum & & \\
\hline \multirow[t]{4}{*}{ Fusarium graminearum } & Myzel & 4 bis 35 & 28 & -2 bis -28 & Regen \\
\hline & Perithezien & 5 bis 35 & 29 & -1.5 bis -5 & UV-Licht, Regen \\
\hline & Askosporen & 13 bis 33 & 25 bis 28 & - & UV-Licht \\
\hline & Makrokonidien & 16 bis 36 & 28 bis 32 & -1.4 bis -3 & - \\
\hline \multirow[t]{2}{*}{ Fusarium culmorum } & Myzel & 20 bis 30 & 25 & -8 bis -28 & Regen \\
\hline & Makrokonidien & 20 bis 30 & - & -8 bis -14 & - \\
\hline
\end{tabular}

Fusarium-Infektion führt zu Ernteverlusten, die in Getreide allgemein zwischen 10\% und 30\% ausmachen können [88]. Bei Weizen können diese in Jahren mit starkem Befall bis zu 70\% betragen, während sie bei Gerste mit bis zu 40\% geringer als bei Weizen ausfallen [89, 90]. In Frankreich wird von starkem Befall alle drei bis fünf Jahre ausgegangen, dann können 50-60\% der Getreideanbaufläche befallen sein. Sehr starker Befall mit Ernteverlusten bis $\mathrm{zu} \mathrm{100 \%}$ ist etwa alle 10 Jahre zu beobachten [87]. Monetär wurden die Verluste für die USA zwischen 2 und 2,7 Mrd. Dollar beziffert [83, 85, 87]. In China sind in Jahren mit hohem Befall mehr als 7 Mio. ha Weizen betroffen, was zu Ernteverlusten von ca. 30\% (China Statistical Yearbook 2009) führt [91].

\section{Bildung von Toxinen durch $F$. graminearum und F. culmorum}

Mykotoxine sind toxische Sekundärmetabolite, die von mindestens 200 identifizierten Pilzen wie Fusarium, Aspergillus und Penicillium gebildet werden [92]. F. graminearum und F. culmorum produzieren Toxine, die zur Gruppe der Trichothecene gehören [92, 93]. Typ B-Trichothecene, zu denen Nivalenol (NIV), DON und seine Vorstufen 3- und 15-Acetyldeoxynivalenol (3-Ac-DON und 15-Ac-DON) zählen, werden hauptsächlich von F. graminearum und F. culmorum produziert [77]. Daneben sind weitere Toxine, wie Fusarenone X (FUS) und östrogenwirksame Mykotoxine, wie ZEA, nachgewiesen worden [77, 92, 93]. Die Biosynthese der Trichothecene, die zur Gruppe der Sesquiterpene gehören, leitet sich von Acetyl-CoA ab, wobei im Rahmen der Isoprenoidsynthese das Trichothecene-Grundgerüst aus Farnesylpyrophosphat entsteht [94]. Es wurden bisher zehn Gene identifiziert, d.h. zwei regulatorische Gene, 
sieben Syntheseweggene und ein Transportergen, die für die Synthese von Proteinen kodieren, welche die Trichothecensynthese und den Transport steuern [94].

Gesundheitliche Aspekte der von F. graminearum und F. culmorum produzierten Toxine bei Mensch und Tier

Toxische Effekte, die durch Fusarium-Trichothecene verursacht werden und zum Ausbruch einer oralen Mykotoxikose nach Verzehr belasteter Lebensmittel in der Bevölkerung führten, wurden bereits für die 30er Jahre des 20. Jahrhunderts in Russland (1932-47) und in späteren Jahren auch für Japan (1956), China (1961-1985, 1984-1985) sowie für Indien 1987 beschrieben [95]. Daneben ist auch über Mykotoxikosen nach Inhalation oder Hautkontakt in den USA und Kanada berichtet worden [95]. Biochemisch gesehen sind Trichothecene potente Inhibitoren der Proteinbiosynthese in Säugetierzellen. DON, das am häufigsten gebildete Trichothecen, bindet an die Peptidyltransferase, einen integralen Bestandteil der 60S-ribosomalen Untereinheit, und führt so zur Hemmung der Proteinbiosynthese [96, 97]. Weiterhin ist eine Hemmung der DNA- und RNA-Biosynthese nachgewiesen worden [96]. Zusammen können diese Effekte die Selbstregulation der Zelle stören und durch intrazelluläre Signalkaskaden, z.B. Kinase-Kaskaden, zu Zellvermehrung, Differenzierung und zur Apoptose, einer Form des programmierten Zelltodes, führen [96, 98]. Eine durch Trichothecene ausgelöste Mykotoxikose kann so in Säugetieren zu verringerter und veränderter Nahrungsaufnahme, damit verbundenem Gewichtsverlust und durch die Beeinflussung des serotoninergen Systems (Serotonin: Gewebshormon, Neurotransmitter), Übelkeit und Erbrechen, Durchfall und Blutungen im Verdauungstrakt führen. Darüber hinaus kann es zu einer Beeinflussung der Immunfunktion, wie Immunsuppression oder Immunstimulation) sowie Erkrankungen der Niere (z.B. Nephropathie) durch Autoimmunreaktionen und proinflammatorische Effekte durch Stimulation von Makrophagen und T-Helferzellen des Immunsystems kommen [95-97, 99-101]. In der Tierernährung zeigen Schweine die höchste Sensitivität gegenüber DON, gefolgt von Nagetieren, Hunden, Katzen, Geflügel und Wiederkäuern [98]. ZEA wirkt auf einen nuklären Östrogenrezeptor und beeinflusst direkt die Synthese der „Target-Gen“-RNA was zur Störung des Immunsystems und der Stimulation von Brustkrebszellen führen kann [102].

\section{Befall von Emmer (Triticum dicoccum) mit Fusarium}

Wilder Emmer (Triticum diccocoides) wird in der Literatur als hoch anfällig für FHB, insbesondere wenn durch F. gramninearum verursacht, beschrieben. Von 151 
untersuchten Genotypen zeigten nur fünf eine geringe Anfälligkeit [103]. Andere Untersuchungen an Emmer belegen ein breiteres Spektrum in der Anfälligkeit gegenüber F. graminearum und beschreiben die gering anfälligen Sorten als potentielle Quelle, um die Anfälligkeit gegen FHB durch Züchtung zu reduzieren [104]. Dabei gilt die Spelze als wichtigste Barriere gegen die Infektion (Typ I-Resistenz), zusätzlich werden aktive Resistenzmechanismen für wilden Emmer beschrieben (Typ II-Resistenz) (Tab. 5). Dieser Typ II Resistenztyp unterscheidet sich von dem in Weizen bekannten durch den Genort auf Chromosom 3A (Tab. 5) [11, 103]. Eine weitere Studie zur Lokalisierung von Genen, die die Anfälligkeit gegen Fusarium bei Emmer beeinflussen, beschreibt eine Region auf dem langen Arm von Chromosom 2A als verantwortlich für eine unterschiedliche Ausprägung der Anfälligkeit gegenüber FHB [107]. Im Vergleich mit Einkorn mit im Mittel $18 \mathrm{mg} \mathrm{kg}^{-1}$ DON war Emmer mit $13 \mathrm{mg} \mathrm{kg}^{-1}$ DON nach künstlicher Infektion mit F. culmorum etwas weniger belastet. Im Vergleich zu Spelt (Dinkel, Triticum spelta) mit $8 \mathrm{mg} \mathrm{kg}^{-1}$ DON und Weizen der Sorte Sumai-3 mit $6 \mathrm{mg}$ $\mathrm{kg}^{-1}$ DON ist die Anfälligkeit von Emmer gegenüber F. culmorum auf Grundlage der DON-Produktion aber als höher einzustufen, was die These einer höheren Anfälligkeit von Emmer im Vergleich zu Weizen stützt [13]. Die Weizensorte Sumai-3 zeigt die geringste bekannte Anfälligkeit gegenüber FHB und DON-Akkumulation. Diese Typ IIResistenz soll dabei auf Genen beruhen, die auf den Chromosomen 7A, 3B, 2B und 6B liegen, während auf dem D-Genom liegende Resistenzgene hier nicht nachgewiesen werden konnten (Tab. 5) [91]. 
Tab. 5 Einteilung von Abwehrmechanismen gegen Fusarium-Infektion in Getreide [85, $87,91,105,106]$

\begin{tabular}{|c|c|c|c|}
\hline & Resistenztyp & & Beschreibung \\
\hline \multirow{3}{*}{1} & & Passiv & $\begin{array}{c}\text { Mechanische Barriere } \\
\text { (Spelze, offen oder geschlossen blühend) }\end{array}$ \\
\hline & Widerstandsfähigkeit gegen die initiale Infektion & & \\
\hline & & Aktiv & $\begin{array}{c}\text { Abwehrreaktion der Pflanzenzelle } \\
\text { (z.B. Chitinase Abbau der Pilzzellwand) }\end{array}$ \\
\hline II & $\begin{array}{l}\text { Widerstandsfähigkeit gegen die } \\
\text { Krankheitsausbreitung }\end{array}$ & Aktiv & $\begin{array}{c}\text { Zunahme der Stabilität der Pflanzenzellwand } \\
\text { (Lignifizierung), Hemmung des Deoxynivalenol } \\
\text { Transports }\end{array}$ \\
\hline III & $\begin{array}{c}\text { Widerstandsfähigkeit gegen die Infektion der } \\
\text { Körner }\end{array}$ & Aktiv & $\begin{array}{l}\text { Morphologische Veränderungen des Korns } \\
\text { (Komplex von Maßnahmen Typ I, II, IV, V)) }\end{array}$ \\
\hline IV & $\begin{array}{l}\text { Toleranz gegen die Infektion und Deoxynivalenol } \\
\text { (2 Subtypen Class } 1 \text { und Class } 2 \text { ) }\end{array}$ & Aktiv & Metabolisierung von Deoxynivalenol \\
\hline $\mathrm{V}$ & $\begin{array}{l}\text { Toleranz gegen die Akkumulation von } \\
\text { Trichothecenen } \\
\text { (2 Subtypen Class } 1 \text { und Class 2) }\end{array}$ & Aktiv & $\begin{array}{c}\text { Modifizierte Peptidyltransferase der Ribosomen } \\
\text { und verringerte Beeinflussung durch } \\
\text { Deoxynivalenol }\end{array}$ \\
\hline Class 1 & $\begin{array}{l}\text { Chemische Modifikation der Trichothecene } \\
\text { (Metabolisierung) }\end{array}$ & Aktiv & $\begin{array}{l}\text { Glycosylierung, Acetylierung, De-Epoxidierung, } \\
\text { Export aus der Zelle }\end{array}$ \\
\hline Class 2 & $\begin{array}{l}\text { Hemmung der Trichothecensynthese, } \\
\text { Pilzwachstumarrest }\end{array}$ & Aktiv & $\begin{array}{l}\text { Zellwand-assoziierte Pflanzentoxine (Phenole, } \\
\text { Peptide), Enzyme }\end{array}$ \\
\hline
\end{tabular}

\section{Befall von Nacktgerste (Hordeum vulgare ssp. nudum) mit Fusarium}

Nacktgerste wurde bisher nur sehr wenig in Bezug auf ihre Anfälligkeit gegenüber Fusarium untersucht. Ein Vergleich der Toxinproduktion zwischen Gerste und Nacktgerste in Korea (1990) zeigte, dass die Kontamination mit NIV in Nacktgerste mit $0,09-4,57 \mathrm{mg} \mathrm{kg}^{-1}$ höher war als in der bespelzten Gerste, wo der NIV-Gehalt 0,11 $1,55 \mathrm{mg} \mathrm{kg}^{-1}$ betrug. DON und ZEA wurden in Nacktgerste mit $0,04-0,65 \mathrm{mg} \mathrm{kg}^{-1}$ und $0,04-1,08 \mathrm{mg} \mathrm{kg}^{-1}$ in etwas geringeren Mengen als in den bespelzten Sorten mit 0,03$0,68 \mathrm{mg} \mathrm{kg}{ }^{-1}$ und $0,18-1,42 \mathrm{mg} \mathrm{kg}^{-1}$ nachgewiesen [108]. Der Vergleich der Infektionsstärke von koreanischer zweizeiliger bespelzter Braugerste (57\%) mit sechszeiliger bespelzter Gerste (89\%) und sechszeiliger Nacktgerste (38\%) zeigte für die Nacktgerste den geringsten Befall [109]. Der DON-Gehalt war jedoch in zweizeiliger bespelzter Braugerste mit $0,44 \mathrm{mg} \mathrm{kg}^{-1}$ am geringsten. Sechszeilige bespelzte Gerste zeigte mit $1,19 \mathrm{mg} \mathrm{kg}^{-1}$ den höchsten DON-Gehalt, sechszeilige Nacktgerste mit 0,59 $\mathrm{mg} \mathrm{kg}^{-1}$ lag im Bereich der Braugerste, was eine geringere Anfälligkeit der Nacktgersteformen im Vergleich zu bespelzter Gerste nahelegt [109]. 
Zweizeilige Gerstensorten werden auch in anderen Arbeiten im Vergleich zu sechszeiligen Gerstensorten als weniger anfällig gegen Fusarium-Infektion beschrieben [91, 110]. Im Vergleich zu Weizen ist der hauptsächliche Mechanismus, der zu geringer Anfälligkeit führt, bei Gerste die Typ I- Resistenz und passiv (Tab. 5) [91]. Es finden sich einige Merkmale bei zweizeiliger Gerste, die für die passive geringere Anfälligkeit verantwortlich gemacht werden, wie gefärbte Deckspelzen, lange Spelzgrannen, eine größere Bestandshöhe und Resistenz gegen das Anheften von Pilzsporen [111]. Keinen Einfluss zeigt dagegen die Länge der Ährenachsenhärchen oder die Rauheit der Deckspelzengrannen [111]. Daneben spielt auch offenes (chasmogamous) oder geschlossenes (cleistogamous) Blühen eine Rolle in der Anfälligkeit gegenüber Fusarium-Infektion (Tab. 5) [45]. Geschlossen blühende Gerstensorten zeigen keine Anfälligkeit während der Blüte, sondern erst 10 Tage nach Abblühen (Tab. 5). Offen blühende Gerste war dagegen bereits während der Blüte, der kritischen Phase für eine Fusarium-Infektion und Mykotoxin-Akkumulation, anfällig [45]. Weiterhin konnte gezeigt werden, dass die Bildung von Trichothecenen während der initialen Phase (siehe Epidemiologie von Fusarium) keine Bedeutung für den Erfolg der Infektion der Fruchtschale bei Weizen und Gerste hat $[106,112]$. Das Fehlen von Trichothecenen bei der Infektion von Weizen führte dagegen zu einem Wachstumsstopp von Fusarium am Spindelknoten durch starke Verdickung der Zellwand [112]. Dieser Abwehrmechanismus wird durch die Trichothecene gehemmt und ermöglicht so das weitere Ausbreiten des Pilzes über die Getreidespindel in andere Ährchen der Ähre [112]. Im Vergleich dazu zeigt sich, dass bei Gerste ein Weiterwachsen des Pilzes in die Spindel auch nach Toxinsynthese nicht stattfindet, so dass weitere Teile der Ähre nicht infiziert werden können. Dies begründet neben andere Faktoren eine geringere Anfälligkeit von Gerste im Vergleich zu Weizen [112]. Darüber hinaus findet sich ein Unterschied bei der initialen Infektion von Weizen und Gerste. Im Weizen erfolgt die primäre Infektion über die Antheren, während dies in Gerste nicht zu beobachten ist [85]. 


\subsection{Referenzen}

[1] Kellogg, E. A., The grasses: A case study in macroevolution. Annu. Rev. Ecol. Syst. 2000, 31, 217-238.

[2] Dubcovsky, J., Dvorak, J., Genome plasticity a key factor in the success of polyploid wheat under domestication (vol 316, pg 1862, 2007). Science 2007, 318, 393-393.

[3] Luo, M. C., Yang, Z. L., You, F. M., Kawahara, T., et al., The structure of wild and domesticated emmer wheat populations, gene flow between them, and the site of emmer domestication. Theor. Appl. Genet. 2007, 114, 947-959.

[4] Mielke, H., Rodemann, B., Zum Anbau und Pflanzenschutz einer wieder entdeckten Weizenart: Emmer (Triticum dicoccum). Nachrichtenblatt Deutscher Pflanzenschutz 2007, 59, 138-140.

[5] Shewry, P. R., Wheat. J. Exp. Bot. 2009, 60, 1537-1553.

[6] Vonier, H., in: www.rette-sich-wer-kann.com 2008, Abrufdatum: 15.02.2010.

[7] Balter, M., Seeking agriculture's ancient roots. Science 2007, 316, 1830-1835.

[8] Akhunov, E. D., Akhunova, A. R., Dvorak, J., BAC libraries of Triticum urartu, Aegilops speltoides and Ae. tauschii, the diploid ancestors of polyploid wheat. Theor. Appl. Genet. 2005, $111,1617-1622$.

[9] Kling, C. I., Nutzung genetischer Ressourcen für die Evaluierung von Einkorn und Emmer im Hinblick auf deren Einsatz in der Praxis Tagungsband On-farm-Erhaltung genetischer Ressourcen von Getreide und Ölpflanzen 2004, 111, 17-27.

[10] Pagnotta, M. A., Mondini, L., Atallah, M., Morphological and molecular characterization of Italian emmer wheat accessions. Euphytica 2005, 146, 29-37.

[11] Degaonkar, A. M., Tamhankar, S. A., Rao, V. S., An assessment of cultivated emmer germplasm for gluten proteins - Polymorphism of gluten proteins in cultivated emmer germplasm. Euphytica 2005, 145, 49-55.

[12] Pagnotta, M. A., Mondini, L., Codianni, P., Fares, C., Agronomical, quality, and molecular characterization of twenty Italian emmer wheat (Triticum dicoccon) accessions. Genet. Resour. Crop Evol. 2009, 56, 299-310.

[13] Suchowilska, E., Kandler, W., Sulyok, M., Wiwart, M., Krska, R., Mycotoxin profiles in the grain of Triticum monococcum, Triticum dicoccum and Triticum spelta after head infection with Fusarium culmorum. J. Sci. Food Agric. 2010, 90, 556-565.

[14] Itter, S., in: www.eiwels-kirchberg.de, Abrufdatum: 13.02.2010.

[15] Jantsch, P., Trautz, D., 2003.

[16] vanderVeen, M., Palmer, C., Environmental factors and the yield potential of ancient wheat crops. J. Archaeol. Sci. 1997, 24, 163-182.

[17] Drangmeister, H., in: Bundesministerium für Verbraucherschutz, E. u. L. (Ed.), D2 Spezieller Pflanzenbau 2004.

[18] Ernährung, B. f. L. u., in: www.oekolandbau.de 2009, Abrufdatum: 25.02.2010.

[19] Wieser, H., Comparative investigations of gluten proteins from different wheat species I. Qualitative and quantitative composition of gluten protein types. Eur. Food Res. Technol. 2000, 211, 262-268.

[20] Islam, N., Tsujimoto, H., Hirano, H., Proteome analysis of diploid tetraploid and hexaploid wheat: Towards understanding genome interaction in protein expression. Proteomics 2003, 3, 549-557.

[21] Piergiovanni, A. R., Extraction and separation of water-soluble proteins from different wheat species by acidic capillary electrophoresis. J. Agric. Food Chem. 2007, 55, 3850-3856. 
[22] Gao, S. C., Gu, Y. Q., Wu, J. J., Coleman-Derr, D., et al., Rapid evolution and complex structural organization in genomic regions harboring multiple prolamin genes in the polyploid wheat genome. Plant Mol.Biol. 2007, 65, 189-203.

[23] Ikeda, T. M., Araki, E., Fujita, Y., Yano, H., Characterization of low-molecular-weight glutenin subunit genes and their protein products in common wheats. Theor. Appl. Genet. 2006, $112,327-334$.

[24] Mills, E. N. C., Field, J. M., Kauffman, J. A., Tatham, A. S., et al., Characterization of a monoclonal antibody specific for HMW subunits of glutenin and its use to investigate glutenin polymers. J. Agric. Food Chem. 2000, 48, 611-617.

[25] Cunsolo, V., Foti, S., Saletti, R., Mass spectrometry in the characterisation of cereal seed proteins. Eur. J. Mass Spectrom. 2004, 10, 359-370.

[26] Ferranti, P., Marnone, G. R., Picariello, G., Addeo, F., Mass spectrometry analysis of gliadins in celiac disease. J. Mass Spectrom. 2007, 42, 1531-1548.

[27] Shewry, P. R., Halford, N. G., Cereal seed storage proteins: structures, properties and role in grain utilization. J. Exp. Bot. 2002, 53, 947-958.

[28] van Eckert, R., Berghofer, E., Ciclitira, P. J., Chirdo, F., et al., Towards a new gliadin reference material-isolation and characterisation. J. Cereal Sci. 2006, 43, 331-341.

[29] Ral, J. P., Cavanagh, C. R., Larroque, O., Regina, A., Morell, M. K., Structural and molecular basis of starch viscosity in hexaploid wheat. J. Agric. Food Chem. 2008, 56, 41884197.

[30] Vollmann, J., Grausgruber, H., Ruckenbauer, P., Variability in chemical composition and biologically active constituents of cereals. Genetic Variation for Plant Breeding, 2004, 23-26.

[31] Piber, M., Koehler, P., Identification of dehydro-ferulic acid-tyrosine in rye and wheat: Evidence for a covalent cross-link between arabinoxylans and proteins. J. Agric. Food Chem. 2005, 53, 5276-5284.

[33] Bustamante-Rangel, M., Delgado-Zamarreno, M. M., Sanchez-Perez, A., CarabiasMartinez, R., Determination of tocopherols and tocotrienols in cereals by pressurized liquid extraction-liquid chromatography-mass spectrometry. Anal. Chim. Acta 2007, 587, 216-221.

[34] Rudi, H., Uhlen, A. K., Harstad, O. M., Munck, L., Genetic variability in cereal carbohydrate compositions and potentials for improving nutritional value. Anim. Feed Sci. Technol. 2006, 130, 55-65.

[35] Evers, A. D., Blakeney, A. B., O'Brien, L., Cereal structure and composition. Aust. J. Agric. Res. 1999, 50, 629-650.

[36] Gessendorfer, B., Koehler, P., Wieser, H., Preparation and characterization of enzymatically hydrolyzed prolamins from wheat, rye, and barley as references for the immunochemical quantitation of partially hydrolyzed gluten. Anal. Bioanal. Chem. 2009, 395, 1721-1728.

[37] Dewar, D., Pereira, S. P., Ciclitira, P. J., The pathogenesis of coeliac disease. Int. J. Biochem. Cell Biol. 2004, 36, 17-24.

[38] Polanco, I., Celiac disease. J. Pediatr. Gastroenterol. Nutr. 2008, 47, S3-S6.

[39] Hamer, R. J., Coeliac Disease: Background and biochemical aspects. Biotechnol. Adv. 2005, 23, 401-408.

[40] McIntosh, G. H., Royle, P. J., Pointing, G., Wheat aleurone flour increases cecal betaglucuronidase activity and butyrate concentration and reduces colon adenoma burden in azoxymethane-treated rats. J. Nutr. 2001, 131, 127-131.

[41] Schachl, R., in: Bundesamt für Agrarbiologie, Ö., Förderungsdienst 1998.

[42] Badr, A., Muller, K., Schafer-Pregl, R., El Rabey, H., et al., On the origin and domestication history of barley (Hordeum vulgare). Mol. Biol. Evol. 2000, 17, 499-510.

[43] Han, Z., Wu, F., Deng, G., Qian, G., et al., Structural and expressional analysis of the Bhordein genes in Tibetan hull-less barley. Genetica 2009, 138, 227-239. 
[44] Glemin, S., Bataillon, T., A comparative view of the evolution of grasses under domestication. New Phytol. 2009, 183, 273-290.

[45] Yoshida, M., Kawada, N., Nakajima, T., Effect of infection timing on fusarium head blight and mycotoxin accumulation in open- and closed-flowering barley. Phytopathology 2007, 97, 1054-1062.

[46] Jakob, S. S., Meister, A., Blattner, F. R., Considerable genome size variation of Hordeum species (Poaceae) is linked to phylogeny, life form, ecology, and speciation rates. Mol. Biol. Evol. 2004, 21, 860-869.

[47] Sandhu, D., Gill, K. S., Gene-containing regions of wheat and the other grass genomes. Plant Physiol. 2002, 128, 803-811.

[48] Barker, G. L. A., Edwards, K. J., A genome-wide analysis of single nucleotide polymorphism diversity in the world's major cereal crops. Plant Biotechnol. J. 2009, 7, 318-325.

[49] Saisho, D., Purugganan, M. D., Molecular phylogeography of domesticated barley traces expansion of agriculture in the Old World. Genetics 2007, 177, 1765-1776.

[50] Bhatty, R. S., The potential of hull-less barley. Cereal Chem. 1999, 76, 589-599.

[51] Wikipedia, in: http://de.wikipedia.org/wiki/Gerste, Gerste 2010, Abrufdatum: 15.03.2010.

[52] Han, Z. X., Qian, G., Wu, F., Pan, Z. F., et al., Sequences variation and classification of Bhordein genes in hull-less barley from the Qinghai-Tibet Plateau. Mol. Biol. 2008, 42, 56-63.

[53] Müller, K. J., in: www.darzau.de, Gerste 2009, Abrufdatum: 15.03.2010.

[54] Rakcejeva, T., Skudra, L., Iljins, U., Biological Value Changes in Wheat, Rye and Hullless Barley Grain During Biological Activation time. Latvijas Lauksaimniecibas Universitates Raksti 2007, 18, 25-33.

[55] myProduct.at, in: http://www.myproduct.at/content/nacktgerste, Meierhof 2010, Abrufdatum: 17.03.2010.

[56] Yeung, J., Vasanthan, T., Pearling of hull-less barley: Product composition and gel color of pearled barley flours as affected by the degree of pearling. J. Agric. Food Chem. 2001, 49, 331335 .

[57] Han, Z. X., Wu, F., Deng, G. B., Qian, G., et al., Structural and expressional analysis of the B-hordein genes in Tibetan hull-less barley. Genetica 2010, 138, 227-239.

[58] Agu, R. C., Bringhurst, T. A., Brosnan, J. M., Pearson, S., Potential of Hull-less Barley Malt for Use in Malt and Grain Whisky Production. J. Inst. Brew. 2009, 115, 128-133.

[59] Diekmann, S., in: www.dieckmann-seeds.de, Gerste 2010, Abrufdatum: 22.03.2010.

[60] Finnie, C., Melchior, S., Roepstorff, P., Svensson, B., Proteome analysis of grain filling and seed maturation in barley. Plant Physiol. 2002, 129, 1308-1319.

[61] Ostergaard, O., Finnie, C., Laugesen, S., Roepstorff, P., Svensson, B., Proteome analysis of

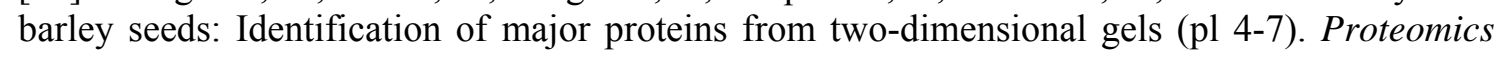
2004, 4, 2437-2447.

[62] Kuwabara, C., Takezawa, D., Shimada, T., Hamada, T., et al., Abscisic acid- and coldinduced thaumatin-like protein in winter wheat has an antifungal activity against snow mould, Microdochium nivale. Physiol. Plant. 2002, 115, 101-110.

[63] Qi, J.-c., Chen, J.-x., Wang, J.-m., Wu, F.-b., et al., Protein and hordein fraction content in barley seeds as affected by sowing date and their relations to malting quality. $J$ Zhejiang Univ Sci B 2005, 6, 1069-1075.

[64] Salplachta, J., Bobalova, J., MALDI-TOF mass spectrometry of hordeins: rapid approach for identification of malting barley varieties. J. Mass Spectrom. 2009, 44, 1287-1292.

[65] Ibrahim, K. M., Hayter, J. B. R., Barrett, J. A., Frequency changes in storage protein genes in a hybrid bulk population of barley. Heredity 1996, 77, 231-239. 
[66] Lange, M., Vincze, E., Wieser, H., Schjoerring, J. K., Holm, P. B., Suppression of Chordein synthesis in barley by antisense constructs results in a more balanced amino acid composition. J. Agric. Food Chem. 2007, 55, 6074-6081.

[67] Sullivan, P., O'Flaherty, J., Brunton, N., Gee, V. L., et al., Chemical composition and microstructure of milled barley fractions. Eur. Food Res. Technol. 2010, 230, 579-595.

[68] Souci, S. W., Fachmann, W., Kraut, H., Die Zusammensetzung der Lebensmittel, 1990.

[69] Andersson, A. A. M., Lampi, A. M., Nystrom, L., Piironen, V., et al., Phytochemical and Dietary Fiber Components in Barley Varieties in the Healthgrain Diversity Screen. J. Agric. Food Chem. 2008, 56, 9767-9776.

[70] Trogh, I., Croes, E., Courtin, C. M., Delcour, J. A., Enzymic degradability of hull-less barley flour alkali-solubilized arabinoxylan fractions by endoxylanases. J. Agric. Food Chem. 2005, 53, 7243-7250.

[71] Kim, M. J., Hyun, J. N., Kim, J. A., Park, J. C., et al., Relationship between phenolic compounds, anthocyanins content and antioxidant activity in colored barley germplasm. $J$. Agric. Food Chem. 2007, 55, 4802-4809.

[72] Santos-Buelga, C., Scalbert, A., Proanthocyanidins and tannin-like compounds - nature, occurrence, dietary intake and effects on nutrition and health. J. Sci. Food Agric. 2000, 80, 1094-1117.

[73] Quinde-Axtell, Z., Baik, B. K., Phenolic compounds of barley grain and their implication in food product discoloration. J Agric Food Chem 2006, 54, 9978-9984.

[74] Dixon, R. A., Natural products and plant disease resistance. Nature 2001, 411, 843-847.

[75] Zagoskina, N. V., Olenichenko, N. A., Iun'vei, C., Zhivukhina, E. A., [Formation of phenol compounds in various cultivars of wheat (Triticum aestivum L.)]. Prikl Biokhim Mikrobiol 2005, 41, 113-116.

[76] Bhadauria, V., Banniza, S., Wang, L. X., Wei, Y. D., Peng, Y. L., Proteomic studies of phytopathogenic fungi, oomycetes and their interactions with hosts. Eur. J. Plant Pathol. 2010, 126, 81-95.

[77] Logrieco, A., Bottalico, A., Mule, G., Moretti, A., Perrone, G., Epidemiology of toxigenic fungi and their associated mycotoxins for some Mediterranean crops. Eur. J. Plant Pathol. 2003, 109, 645-667.

[78] Parry, D. W., Jenkinson, P., McLeod, L., Fusarium ear blight (scab) in small-grain cereals a review. Plant Pathol. 1995, 44, 207-238.

[79] Cuomo, C. A., Gueldener, U., Xu, J. R., Trail, F., et al., The Fusarium graminearum genome reveals a link between localized polymorphism and pathogen specialization. Science 2007, 317, 1400-1402.

[80] Ma, L. J., van der Does, H. C., Borkovich, K. A., Coleman, J. J., et al., Comparative genomics reveals mobile pathogenicity chromosomes in Fusarium. Nature 2010, 464, 367-373.

[81] Osborne, L. E., Stein, J. M., Epidemiology of Fusarium head blight on small-grain cereals. Int. J. Food Microbiol. 2007, 119, 103-108.

[82] Yazar, S., Omurtag, G. Z., Fumonisins, Trichothecenes and Zearalenone in Cereals. Int. J. Mol. Sci. 2008, 9, 2062-2090.

[83] Goswami, R. S., Kistler, H. C., Heading for disaster: Fusarium graminearum on cereal crops. Mol. Plant Pathol. 2004, 5, 515-525.

[84] Xu, X. M., Effects of environmental conditions on the development of Fusarium ear blight. Eur. J. Plant Pathol. 2003, 109, 683-689.

[85] Walter, S., Nicholson, P., Doohan, F. M., Action and reaction of host and pathogen during Fusarium head blight disease. New Phytol 2009, 185, 54-66.

[86] Phalip, V., Delalande, F., Carapito, C., Goubet, F., et al., Diversity of the exoproteome of Fusarium graminearum grown on plant cell wall. Curr. Genet. 2005, 48, 366-379. 
[87] Champeil, A., Dore, T., Fourbet, J. F., Fusarium head blight: epidemiological origin of the effects of cultural practices on head blight attacks and the production of mycotoxins by Fusarium in wheat grains. Plant Sci. 2004, 166, 1389-1415.

[88] Bottalico, a., Fusarium diseases of cereals: species complex and related mycotoxin profiles, in Europe. Journal of Plant Pathology 1998, 80, 85-103.

[89] Bai, G. H., Shaner, G., Scab of wheat - prospects for control. Plant Dis. 1994, 78, 760-766.

[90] McMullen, M., Jones, R., Gallenberg, D., Scab of wheat and barley: A re-emerging disease of devastating impact. Plant Dis. 1997, 81, 1340-1348.

[91] Bai, G. H., Shaner, G., Management and resistance in wheat and barley to Fusarium head blight. Annu. Rev. Phytopathol. 2004, 42, 135-161.

[92] Zollner, P., Mayer-Helm, B., Trace mycotoxin analysis in complex biological and food matrices by liquid chromatography-atmospheric pressure ionisation mass spectrometry. $J$. Chromatogr. A 2006, 1136, 123-169.

[93] Bottalico, A., Perrone, G., Toxigenic Fusarium species and mycotoxins associated with head blight in small-grain cereals in Europe. Eur. J. Plant Pathol. 2002, 108, 611-624.

[94] Kimura, M., Tokai, T., Takahashi-Ando, N., Ohsato, S., Fujimura, M., Molecular and genetic studies of Fusarium trichothecene biosynthesis: Pathways, genes, and evolution. Biosci. Biotechnol. Biochem. 2007, 71, 2105-2123.

[95] Peraica, M., Radic, B., Lucic, A., Pavlovic, M., Toxic effects of mycotoxins in humans. Bull. World Health Organ. 1999, 77, 754-766.

[96] Eriksen, G. S., Pettersson, H., Toxicological evaluation of trichothecenes in animal feed. Anim. Feed Sci. Technol. 2004, 114, 205-239.

[97] Rotter, B. A., Prelusky, D. B., Pestka, J. J., Toxicology of deoxynivalenol (vomitoxin). J. Toxicol. Environ. Health 1996, 48, 1-34.

[98] Pestka, J. J., Smolinski, A. T., Deoxynivalenol: Toxicology and potential effects on humans. J. Toxicol. Env. Health-Pt b-Crit. Rev. 2005, 8, 39-69.

[99] Nielsen, C. C., M. Didier, A. Dietrich, R. Märtlbauer, E. Trichothecene-induced cytotoxicity on human cell lines Mycotoxin Research 2009, 25, 77-84.

[100] Thuvander, A., Wikman, C., Gadhasson, I., In vitro exposure of human lymphocytes to trichothecenes: Individual variation in sensitivity and effects of combined exposure on lymphocyte function. Food Chem. Toxicol. 1999, 37, 639-648.

[101] Yabe, T., Hashimoto, H., Sekijima, M., Degawa, M., et al., Effects of Nivalenol on Hepatic Drug-Metabolizing Activity in Rats. Food Chem. Toxicol. 1993, 31, 573-581.

[102] Konishi, Y., Sugiyama, K. I., The risk assessment of mycotoxins and its international trends. J. Food Hyg. Soc. Jpn. 2008, 49, 1-10.

[103] Buerstmayr, H., Stierschneider, M., Steiner, B., Lemmens, M., et al., Variation for resistance to head blight caused by Fusarium graminearum in wild emmer (Triticum dicoccoides) originating from Israel. Euphytica 2003, 130, 17-23.

[104] Oliver, R. E., Stack, R. W., Miller, J. D., Cai, X., Reaction of wild emmer wheat accessions to Fusarium head blight. Crop Sci. 2007, 47, 893-899.

[105] Boutigny, A. L., Richard-Forget, F., Barreau, C., Natural mechanisms for cereal resistance to the accumulation of Fusarium trichothecenes. Eur. J. Plant Pathol. 2008, 121, 411423.

[106] Foroud, N. A., Eudes, F., Trichothecenes in Cereal Grains. Int. J. Mol. Sci. 2009, 10, 147173.

[107] Garvin, D. F., Stack, R. W., Hansen, J. M., Quantitative Trait Locus Mapping of Increased Fusarium Head Blight Susceptibility Associated with a Wild Emmer Wheat Chromosome. Phytopathology 2009, 99, 447-452. 
[108] Park, K. J., Park, A. R., Lee, Y. W., Natural occurrence of fusarium mycotoxins of the 1990 barley crob in Korea. Food Addit. Contam. 1992, 9, 639-645.

[109] Pei, S. C., Lee, W. J., Kim, S. S., Lee, Y. W., Occurrence of deoxynivalenol in Korean barley and barley products. J. Am. Soc. Brew. Chem. 2004, 62, 93-96.

[110] Choo, T. M., Martin, R. A., Ho, K. M., Shen, Q., et al., Fusarium head blight and deoxynivalenol accumulation of barley in eastern canada: Cultivar response and correlation analysis. Plant Dis. 2004, 88, 837-844.

[111] Choo, T. M., Vigier, B., Shen, Q. Q., Martin, R. A., et al., Barley traits associated with resistance to Fusarium head blight and deoxynivalenol accumulation. Phytopathology 2004, 94, $1145-1150$.

[112] Jansen, C., von Wettstein, D., Schafer, W., Kogel, K. H., et al., Infection patterns in barley and wheat spikes inoculated with wild-type and trichodiene synthase gene disrupted Fusarium graminearum. Proc. Natl. Acad. Sci. U. S. A. 2005, 102, 16892-16897. 



\section{Zielstellung}

Ziel der Arbeit war es, Emmer (Triticum dicoccum) und Nacktgerste (Hordum vulgare ssp. nudum) auf ihre Anfälligkeit gegenüber Fusarium-Befall zu untersuchen. Dazu wurden beide Kulturarten im Feld unter konventionellen Bedingungen angebaut und das Erntegut nach natürlicher und künstlicher Fusarium-Infektion analysiert. Der FusariumBefall wurde im Korn durch DNA von F. graminearum und F. culmorum und die Toxingehalte, v.a. DON, charakterisiert und quantifiziert. Beide Arten wurden bisher wenig oder gar nicht im Zusammenhang mit Fusarium-Befall untersucht.

Die vorliegende Arbeit legt den Fokus der Untersuchungen auf den Einfluss der Fusarium-Infektion auf ausgesuchte Inhaltsstoffe der beiden Getreidearten. Zum Vergleich werden Sommerweizen und Sommergerste herangezogen. Ausgangspunkt ist die Analyse des Fusarium-Befalls an drei Emmer- und sieben Nacktgerstesorten. Zur Beurteilung der Anfälligkeit der Arten gegenüber Fusarium werden die Pilzbiomasse (Fusarium-DNA) und die von Fusarium gebildeten Mykotoxine sowie der Zusammenhang zwischen Fusarium-DNA und Mykotoxinen betrachtet. Beim Emmer soll in diesem Zusammenhang die Bedeutung der Spelzen als mögliche Barriere gegen die Infektion Berücksichtigung finden. Weiterhin sollen an Emmer und Nacktgerste insbesondere phenolische Verbindungen im Zusammenhang mit der Fusarium-Infektion untersucht werden. Diese haben einerseits gesundheitliche Bedeutung in der menschlichen Ernährung, anderseits können sie eine Rolle bei der pflanzlichen Pathogenabwehr spielen. Die Speicherproteine von Emmer und Nacktgerste, die eine bedeutende Rolle bei der Verarbeitungsqualität von Getreideprodukten und in der Ernährung von Tier und Mensch spielen, sind darüber Gegenstand der Untersuchungen. Über den Fusarium-Befall hinaus soll der Einfluss der Standortbedingungen auf die Speicherproteine von Emmer und Nacktgerste untersucht werden. Ergebnisse der Feldversuche zum Einfluss von Fusarium auf die Speicherproteine sollen zusätzlich durch einen in vitro-Versuch gestützt werden, in dem der Abbau von Speicherproteinen durch Fusarium-Proteasen untersucht wird. Mittels 2-D Gelelektrophorese (Proteomics) von jeweils einer ausgewählten Emmer- und einer Nacktgerstesorte und anschließender Identifizierung von durch Fusarium-Befall veränderten Proteinen sollen Abwehrstrategien der beiden Kulturarten und Veränderungen im Proteom in Verbindung mit der Fusarium-Infektion betrachtet werden. 



\section{Material und Methoden}

\section{Anbau von Emmer und Nacktgerste}

Emmer und Nacktgerste wurden in den Jahren 2007 und 2008 auf den Standorten Sattenhausen, $15 \mathrm{~km}$ südöstlich von Göttingen, und Reinshof, etwa $5 \mathrm{~km}$ südlich von Göttingen, angebaut. Die Standortbedingungen und die Versorgung mit Stickstoff, Kalium und Phosphor sind in Tabelle 6 zuasmmengefasst. Die zu untersuchenden drei Emmer- und sieben Nacktgerstesorten wurden als Sommerformen von verschiedenen Züchtern bereitgestellt, E. Irion (Emmer): Linie 9-102, Far-108, Hein 101, H. W. Klein (Emmer) : Klein, K-J. Müller (Nacktgerste): Lawina, Linz, Yonas, ZFS, Frealishe, SFA, R. Einfeld (Nacktgerste): 00/900/5N, Taiga, PRBL 4. Der Versuch wurde als Blockanlage mit vierfacher Wiederholung zweifaktoriell angelegt (Sorte x Art der Inokulation). Alle Sorten wurden jeweils im Vergleich zu einer natürlichen FusariumInfektion (Kontrolle) künstlich mit Fusarium-Sporen während der Blüte inokuliert (künstliche Fusarium-Infektion). Auf beiden Standorten wurden an den Rändern der Emmerparzellen Sommerweizen der Sorte Amaretto und in den Randparzellen der Nacktgerste die Sommergerstesorte Barke ausgesät.

Tab. 6 Standortbedingungen und Düngung in den Jahren 2007 und $2008\left(\mathrm{~N}_{\min }\right.$ bis 90 cm, Stickstoff (N); Kalium (K); Phosphat (P))

Standort

\begin{tabular}{|c|c|c|c|c|}
\hline \multirow[t]{2}{*}{ Düngung } & \multicolumn{2}{|c|}{ Sattenhausen } & \multicolumn{2}{|c|}{ Reinshof } \\
\hline & 2007 & 2008 & 2007 & 2008 \\
\hline $\mathrm{NN}(\mathrm{m})$ & \multicolumn{2}{|c|}{260} & \multicolumn{2}{|c|}{152} \\
\hline Lage & \multicolumn{2}{|c|}{ Hüggellage, windig } & \multicolumn{2}{|c|}{ Flussnähe, windgeschützt } \\
\hline pH-Wert Boden & \multicolumn{2}{|c|}{6} & \multicolumn{2}{|c|}{7} \\
\hline $\mathrm{N}_{\min }\left(\mathrm{kg} \mathrm{ha}^{-1}\right)$ & 95 & 29 & 145 & 19 \\
\hline N Düngung (kg ha $\left.{ }^{-1}\right)$ & $\begin{array}{c}40 \\
\text { (zwei Monate } \\
\text { nach Aussaat) }\end{array}$ & $\begin{array}{c}90 \\
\text { (12 Tage vor } \\
\text { Aussaat) }\end{array}$ & - & $\begin{array}{c}2 \times 50 \\
\text { (18 und } 37 \text { Tage } \\
\text { nach Aussaat) }\end{array}$ \\
\hline$K$ und $P$ Düngung & \multicolumn{4}{|c|}{ Nach Bedarf auf Gehaltsklasse C } \\
\hline
\end{tabular}


Die Aussaat erfolgte in beiden Jahren jeweils Mitte April (12.-23.04.). Das Saatgut wurde mit einer Dichte von 280 Körnern $\mathrm{m}^{-2}$, einem Reihenabstand von $18 \mathrm{~cm}$ und einer Saattiefe von 2-3 cm ausgebracht. Aufgrund des unterschiedlichen Abreifeverhaltens der Kulturarten und Sorten ergaben sich verschiedene Erntezeitpunkte. Die gesamte Ernte von Emmer und Nacktgerste erstreckte sich in beiden Jahren über den Zeitraum Ende Juli (31.07.) bis Ende August (27.08).

\section{Anzucht der Konidosporen und Inokulation}

Die verwendeten F. graminearum- (FG 142, FG 143, FG 144) und F. culmorum- (FC 34, FC 35, FC 36) Stämme wurden auf aus Bayern stammenden Weizenähren isoliert und dienen als Referenz-Stämme der Abteilung Pflanzenpathologie und Pflanzenschutz des Departments für Nutzpflanzenwissenschaften in der Fakultät für Agrarwissenschaften der Georg-August-Universität Göttingen. Die Anzucht der Stämme erfolgte auf Haferflockenagar (20 g Haferflocken, 15 g Agar, $11 \mathrm{H}_{2} \mathrm{O}$ autoklaviert) unter sterilen Bedingungen in Petrischalen bei $23{ }^{\circ} \mathrm{C}$ für $7 \mathrm{~d}$ unter Schwarzlicht. Für die Anzucht der Konidosporen wurde an den Rändern der Petrischale das jüngste Pilzmyzel ausgestochen und unter sterilen Bedingungen auf ein Weizenstrohmedium (9 $\mathrm{g}$ gemahlenes Weizenstroh, $300 \mathrm{ml}$ Wasser in 11 Erlenmeyerkolben, Zellstoffstopfen und Aluminiumfolie zum Verschließen, autoklaviert, 200ppm Streptomycin) überführt und für $7-10$ d bei $23{ }^{\circ} \mathrm{C}$ unter Schwarzlicht geschüttelt. Die Sporensuspension wurde vom Stroh durch ein feines Küchensieb getrennt und die Sporendichte mittels Fuchs-Rosenthal-Mikrozählkammer (Tiefe 0,2 mm, 1/16 $\mathrm{mm}^{3}$ ) bestimmt. Die Suspension wurde dann mit Wasser auf eine Konzentration $1 \times 10^{5}$ Konidosporen $\mathrm{ml}^{-1}$ verdünnt. F. graminearum und F. culmorum wurden zu jeweils gleichen Teilen eingesetzt, so dass in der Suspension die gleiche Menge an Konidosporen beider Arten vorlag. Die Sprühinokulation erfolgte insgesamt fünf Mal während der Blüte und in späteren Entwicklungsstadien mittels Buckelspritze und einer Suspensionsmenge von ca. $50 \mathrm{ml} \mathrm{m}^{-2}$.

\section{Nacherntebehandlung (Reinigung, Vermahlung, Lagerung)}

Nach der Ernte wurde das Getreide für zwei Wochen im Trockenschrank bei $35^{\circ} \mathrm{C}$ auf einen Feuchtegehalt von 7 bis 10 \% getrocknet. Danach wurden die Proben einer Sorte mit natürlicher Inokulation von einem Standort gemischt, d.h. das Erntegut von vier Parzellen wurde zu einer Mischprobe vereinigt. Die künstlich inokulierten Proben wurden anschließend wie die natürlich infizierten Proben behandelt und ebenfalls zu 
einer Mischprobe vereinigt. Das getrocknete Erntegut wurde mittels Probenreiniger (A/S Rationel Konservice, Dänemark) von Besatz getrennt. Der Emmer wurde anschließend entspelzt (Entspelzer, Baumann Saatzuchtbedarf, Einzelährendrescher, Kurt Pelz, Deutschland) und die Körner nochmals mittels Probenreiniger gereinigt. Die Sommergerste wurde nach der Reinigung zur Entfernung der Spelzen geschält (Labor Schälmaschine, F.H. Schule GmbH, Deutschland). Jedes Kilo Gerste wurde zweimal jeweils 45 s geschält. Die so vorbereiteten gereinigten Körner und Spelzen von Emmer und Gerste wurden dann mittels Rotormühle (ZM 100, Retsch GmbH, Deutschland) mit dem $500 \mu \mathrm{m}$ Sieb vermahlen. Gelagert wurden die Mehlproben in $250 \mathrm{ml}$ LaborWeithalsflaschen $[\mathrm{PE}]$ bei $8{ }^{\circ} \mathrm{C}$ und bei längerer Lagerdauer bei $-20^{\circ} \mathrm{C}$.

\section{Analytik}

Alle analytischen Methoden zur Bestimmung der Mykotoxine, Fusarium-DNA und der Inhaltsstoffe (Phenole, Speicherproteine, Getreide-Proteom) sind in den nachfolgenden Manuskripten im Zusammenhang mit der jeweiligen Fragestellung detailliert beschrieben. Einen Überblick über die verwendeten Methoden gibt Tabelle 7.

\section{Statistik}

Für die statistische Auswertung der Ergebnisse wurden Microsoft Office Excel 2003 und SigmaPlot 10.0 verwendet. 
Tab. 7 Überblick über verwendete Methoden und deren Beschreibung

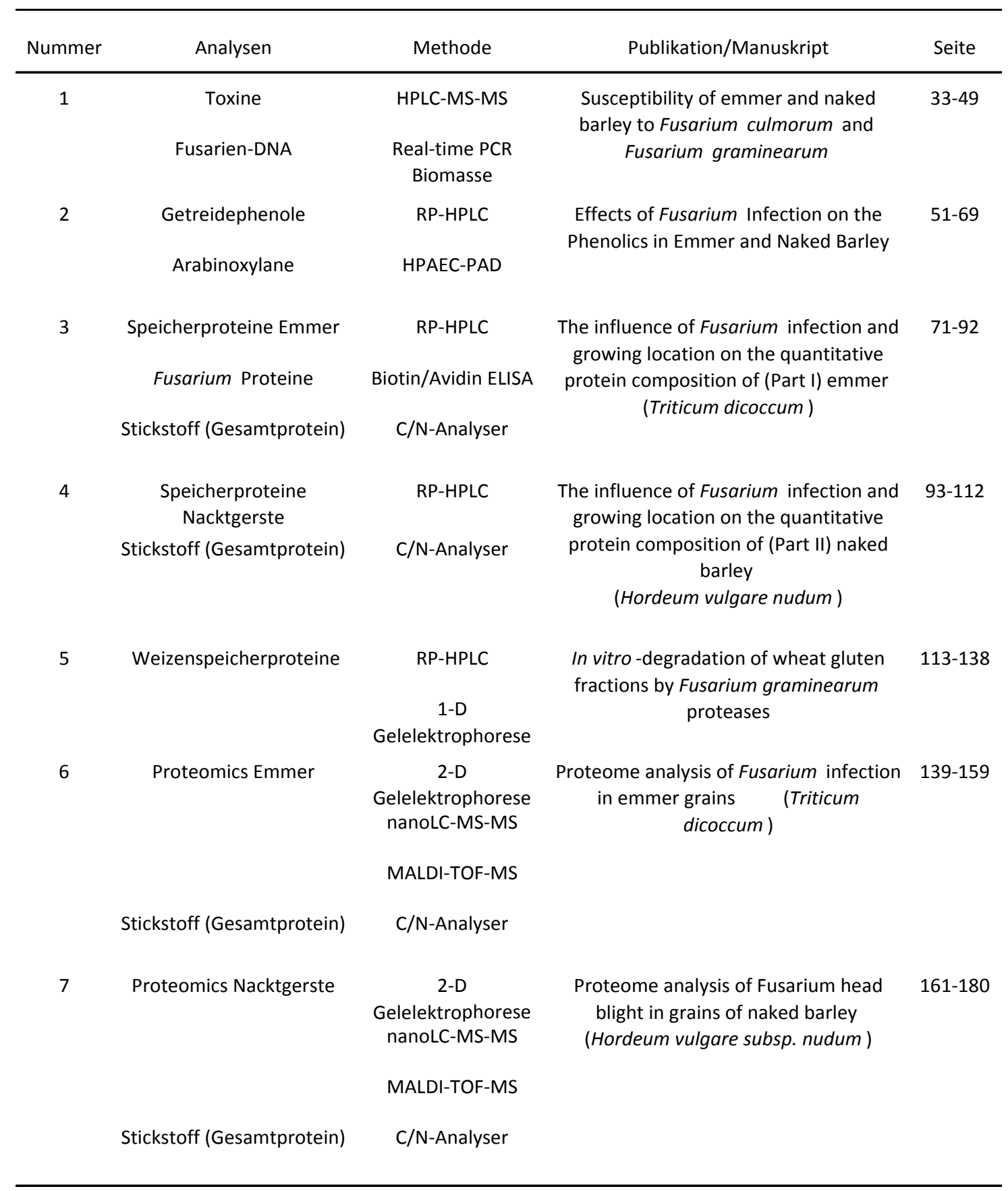

Die Ergebnisse der Arbeit und ihre Diskussion wurden zum Teil bereits publiziert oder liegen für die Veröffentlichung in Manuskriptform nach den Layoutvorgaben der jeweiligen Zeitschriften vor. 


\section{Ergebnisse und Diskussion}

\subsection{Fusarium infection and toxin formation in emmer and naked} barley

Abstract

We investigated the effect of natural and artificial Fusarium infection on the grain species emmer and naked barley. Main objective of the study was to characterize the fungal DNA formation in connection to the toxin formation in these species. Fungal DNA was determined by species-specific real-time PCR and the content of the mycotoxins deoxynivalenol and 3-Ac-deoxynivalenol was estimated with HPLCMS/MS. In natural infected grains Fusarium graminearum was dominant (90\% fungal DNA content) compared to Fusarium culmorum whereas artificial infection with a spore mixture led to nearly equal quantities of DNA of both species. The glume of emmer contained the highest amounts of fungal biomass and trichothecenes in both naturally and artificially infected samples. Naked barley with a glume only loosely fixed to the kernels had the lowest levels of Fusarium colonization and trichothecene content. The content of total Fusarium DNA correlated with the content of trichothecenes in all samples. However in whole grains and glumes of emmer stronger correlations were found than in naked barley grains. The results suggest that in emmer a translocation of deoxynivalenol from glume to the grain occurs. Naked barley flour matrix, but not emmer flour matrix, inhibited PCR.

Keywords: Fusarium head blight (FHB), tetraploide (AABB), trichothecene, conidiospores

\section{Introduction}

Fusarium graminearum and Fusarium culmorum infection of the ears of small grain cereals can lead to dramatic yield and quality losses (Bottalico and Perrone 2002). The disease known as Fusarium head blight (FHB) has become a serious challenge for cereal production throughout the world (Bottalico and Perrone 2002, Foroud and Eudes 2009, Yang et al. 2008, Yazar and Omurtag 2008). In Europe, the most important species causing FHB are F. graminearum and F. culmorum, although the association of a number of further Fusarium species with FHB has been documented in the literature (Parry et al. 1995).

F. graminearum and F. culmorum are producers of trichothecenes, including nivalenol (NIV), deoxynivalenol (DON) and its precursors 3- and 15-acetyldeoxynivalenol (3-Ac- 
DON and 15-Ac-DON, respectively), as well as fusarenone $\mathrm{X}$ and other mycotoxins such as zearalenone (ZEN) (Bottalico and Perrone 2002). The mycotoxins of the trichothecene group are inhibitors of protein synthesis. In mammals, they cause food refusal, vomiting, diarrhoea and bleeding of the intestines at high doses. Other effects lead to a reduced leukocyte content resulting in an impairment of immune function (Eriksen and Pettersson 2004, Nielsen 2009, Thuvander et al. 1999, Yabe et al. 1993). Therefore the reduction of trichothecene content in food and feed is an important task in public health protection and animal production. The problem of mycotoxin contamination has been addressed in the European Union by establishing the maximum amounts of DON allowed in products destined for human food [(EG) Nr. 856/2005. 2006] and for animal nutrition [(EG) Nr. 576/2006. 2006].

The level of Fusarium infection in the field is affected by weather in the vegetation period, previous crop, agricultural practices and the susceptibility of the cultivar itself (Beyer et al. 2006, Klix et al. 2008). For the main types of grain like wheat and barley the effects of the fungal infection are well documented (Bottalico and Perrone 2002, Parry et al. 1995, Yang et al. 2008, Yazar and Omurtag 2008, Yoshida et al. 2007). Our study focused on the potential of two less exploited crops, emmer (Triticum dicoccum) and naked barley (hull-less barley; Hordeum vulgare nudum), to characterize the fungal growing as DNA formation in connection to the toxin formation in these species. Emmer and naked barley have been used mainly in organic farming. So far, little is known about the susceptibility of these crops to Fusarium infection under conventional growing conditions.

Emmer, a tetraploide (AABB) cereal, has shown a high susceptibility to Fusarium in some cultivars but passive resistance (Type I resistance) in others under natural infection conditions (Buerstmayr et al. 2003). The same authors ascertained that the glume acted as a major barrier for the fungus. In cultivars of wild emmer (Triticum dicoccoides) with active resistance, the fungus did not spread from the spikelet to the other parts of the spike (Type II resistance). The genetic basis for this resistance mechanism is located on chromosome $3 \mathrm{~A}$, which is completely different from the resistance loci known in hexaploide wheat (Buerstmayr et al. 2003, Degaonkar et al. 2005).

Naked barley is characterized by high stress resistance, and a short life cycle, and it allows a fast removal of the glume. Furthermore, its high ß-glucan content, as a soluble fibre, has been hypothesized as reducing the prevalence of civilization diseases, e.g 
hypocholesterolemia which can reduce the incidence of cardiovascular disease and chemically induced colon cancer (Bhatty 1999, Han et al. 2008, Helm and de Francisco 2004). Barley is characterized by two types of flowering: chasmagamous (openflowering) and cleistogamous (closed-flowering). During anthesis, the closed-flowering type has a low susceptibility to Fusarium infection, but ten days after anthesis its susceptibility increases in contrast to the open-flowering type, which is already susceptible during anthesis, similar to the situation in wheat (Yoshida et al. 2007). In addition, the germination of Fusarium spp. on barley grain is decelerated in comparison to the germination on wheat (Boddu et al. 2006). Three infection stages have been postulated for F. graminearum's interaction with barley: an early stage within 0-48 $\mathrm{h}$ with limited fungal growth and DON accumulation, an intermediate stage at 48-96 $\mathrm{h}$ in which the most infection-induced host gene transcripts are detected, and a late stage, later than $96 \mathrm{~h}$, with a reduced accumulation of infection-specific gene transcripts, generation of hyphal mats and DON accumulation in the grain (Yoshida et al. 2007).

The response of barley to fungal infection includes the activation of defence response genes; oxidative burst, oxidative stress response, pathogenesis-response-protein genes, programmed cell death; phenylpropanoid pathway and other enzymes (malate dehydrogenase, peroxidase), protease inhibitors, as well as the production of metabolic, regulatory and transport proteins (Boddu et al. 2006, Geddes et al. 2008, Pekkarinen et al. 2007).

In the present study we investigated and compared natural infection of emmer and naked barley with an artificial infection caused by inoculation with F. graminearum and F. culmorum. For these crops commonly grown in organic farming little is known about infection with Fusarium ssp. Hence, our study focused on the characterization of fungal growth, based on DNA formation, in connection with the toxin formation in natural and artificial infected emmer and naked barley species. We were also interested to know which Fusarium species were predominant for these crops in naturally infected plants and which species will dominate after artificial infection with a mixture of $F$. graminearum and F. culmorum. The role of the emmer glume as a mechanical barrier for the fungus and the accumulation of fungal toxins over glume and grain were also investigated.

\section{Material and Methods}

Experimental design and sample preparation 
Three emmer cultivars (linie-9-102, Far-108 + Hein-101, Klein) and seven naked barley cultivars (Lawina, Linz, Frealishe, Yonas, Zfs, Taiga, 00/900/5N) were grown in two separate field trials (Reinshof $[\mathrm{RH}]$ and Sattenhausen $[\mathrm{SH}]$ ) with eight randomized replications (four blocks). Both locations were in the centre of Germany near the town of Göttingen. Summer wheat (cv. Amaretto) and summer barley (cv. Barke) were grown in addition to emmer and naked barley in the borders of the plots as controls.

In each block, the second row was artificially inoculated with a mixed F. culmorum and F. graminearum spore suspension $\left(50 \mathrm{ml} / \mathrm{m}^{2} ; 1 \times 10^{5}\right.$ spores $\left./ \mathrm{ml}\right)$ three times during flowering. Three DON-producing strains of F. culmorum (FC34, FC35, FC36) and F. graminearum (FG142, FG143, FG144) were used for conidiospore production. After harvest, the grains without inoculation [labelled natural infection (-)] and with inoculation [labelled artificial infection $(+)$ ] of the plots (each four replications) from both field trials were pooled.

The emmer was dehusked (Single-spike-thresher, Kurt Pelz, Bad-Godesberg, Germany) and summer barley was abraded (Labor-husking-machine F. H. Schule GmbH, Hamburg, Germany) to remove the glumes. The grains and glumes were milled (Retsch ZM 100, Retsch GmbH, Haan, Germany) to particle sizes of $0.5 \mathrm{~mm}$ and $0.25 \mathrm{~mm}$, respectively.

\section{Real-time PCR for F. graminearum and F. culmorum biomass}

DNA was extracted from $100 \mathrm{mg}$ of dried plant material using a variant of the CTAB protocol as described for wheat rachides (Brandfass and Karlovsky 2006) and purified by polyethylene glycol precipitation (Brandfass and Karlovsky 2008). Real-time PCR for F. culmorum was performed as described previously (Brandfass and Karlovsky 2008). The real-time PCR for F. graminearum was performed under identical conditions except that the $\mathrm{MgCl}_{2}$ concentration was set to $2.5 \mathrm{mM}$.

Standards made of fungal DNA were combined with DNA extracted from uninfected plant material free of Fusarium spp. in order to simulate the effects of the plant matrix on the PCR (Brandfass and Karlovsky 2008). As the DNA extracts from barley strongly inhibited the PCR, these DNA samples were therefore purified by spermin precipitation (Hoppes and Mc Clure 1981). The barley DNA was dissolved in TE buffer (10 mM Tris, $1 \mathrm{mM}$ EDTA, $\mathrm{pH}$ 8.0) and then precipitated by adding spermin to a final concentration of $1 \mathrm{mM}$. After a 10-min incubation at room temperature, the DNA was pelleted by centrifugation at $10,000 \mathrm{x} g$ for $10 \mathrm{~min}$. The pellet was washed twice with $75 \%$ ethanol and incubated over night in an ion-exchange buffer $(75 \mathrm{mM}$ sodium 
acetate and $3.3 \mathrm{mM} \mathrm{MgCl} 2$ in $75 \%$ ethanol). It was subsequently washed with $75 \%$ ethanol again, dried in a vacuum and dissolved in TE buffer.

Estimation of DON, 3-Ac-DON and 15-Ac-DON by HPLC-MS-MS

Whole grain flour $(5 \mathrm{~g})$ and ground glumes $(2.5 \mathrm{~g})$ were extracted with $40 \mathrm{ml}$ of acetonitrile-water mixture (80:20) overnight on a reciprocal shaker. The extracts were centrifuged for $12 \mathrm{~min}$ at $5,000 \mathrm{x} \mathrm{g}$ and $4 \mathrm{ml}$ of the supernatant were used for solidphase extraction (Bond-Elut Mycotoxin, Varian GmbH, Darmstadt, Germany) according to the manufacturer's instructions. Two millilitres of the cleaned extract were evaporated to dryness under vacuum, redissolved in $200 \mu 1$ of methanol-water (50:50) containing $0.2 \mathrm{mM}$ ammonium acetate and filtered through a $0.2-\mu \mathrm{m}$ filter. Ten microliters of the solution were injected onto a C18 column $(100 \times 2 \mathrm{~mm}, 3 \mu \mathrm{m}$ particle size) filled with polar modified material (Polaris Ether, Varian GmbH, Darmstadt, Germany) and the analytes were eluted with a methanol-water gradient ( $15 \%$ to $70 \%$ during $20 \mathrm{~min}$ ) containing $0.2 \mathrm{mM}$ ammonium acetate at a flow rate of $0.2 \mathrm{ml} / \mathrm{min}$. DON, 3-Ac-DON and 15-Ac-DON were detected by tandem mass spectrometry as described in the literature (Adejumo et al. 2007).

Statistical analyses

Analysis was performed using Microsoft Excel 2003 for the average value and standard deviation (SD). The correlation coefficients ( $r$ ) and statistical significance (p) were determined using SigmaPlot 10.0; correlations with $\mathrm{p} \leq 0.05$ were considered significant.

\section{Results}

The fungal colonization, assessed as the content of Fusarium DNA and as the accumulation of the mycotoxins DON and 3-Ac-DON (no 15-Ac-DON was found), showed a significant increase after the artificial infection in the grains of all four cereals (emmer, summer wheat, naked barley and summer barley) compared to natural infection (Table 1). The glume of both emmer and summer barley was colonized with both Fusarium species to a higher degree than the corresponding grain and it contained higher amounts of DON and 3-Ac-DON (Table 1). 
Table 1 Fungal DNA and deoxynivalenol (DON) and 3-acetyl-deoxynivalenol (3-Ac-DON) content in grain flour and glume from naturally and artificially infected samples

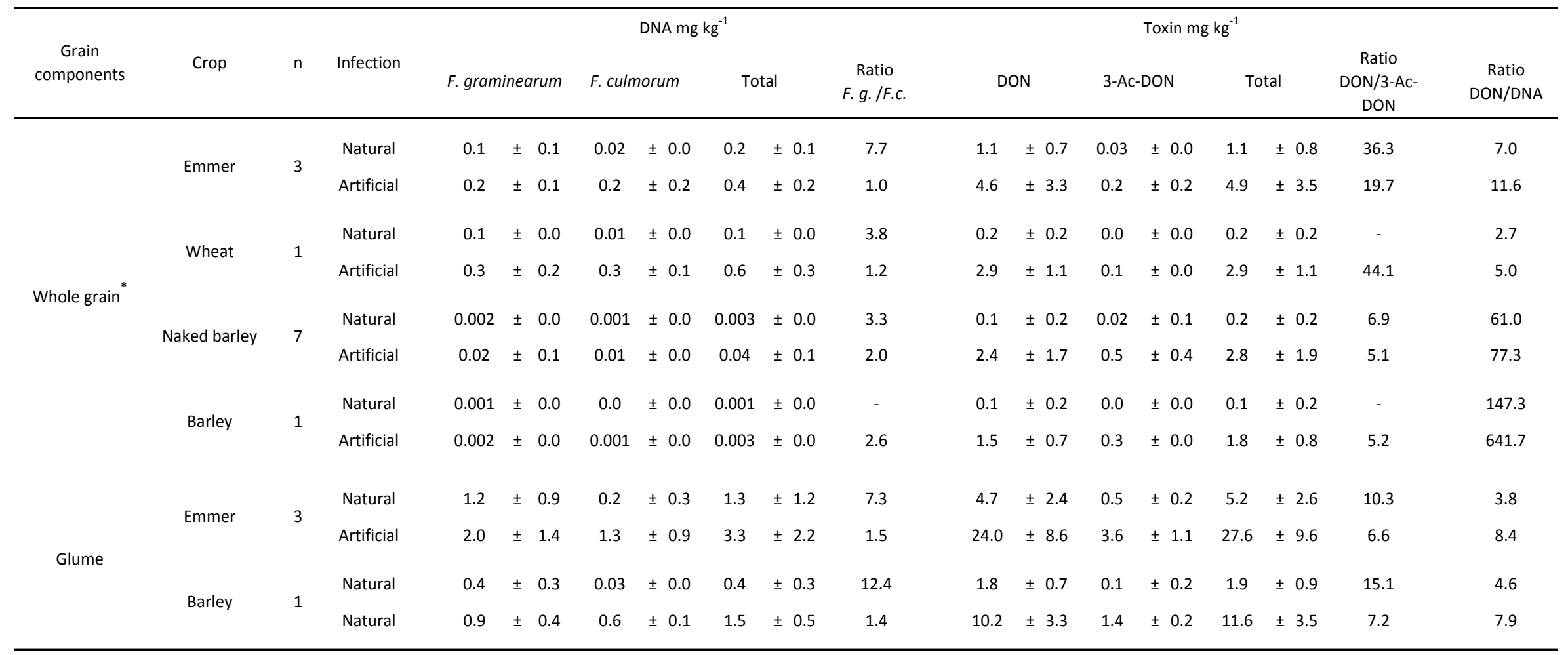

n: number of cultivars; * emmer and barley without glumes; F.g. Fusarium graminearum; F.c. Fusarium culmorum 
The fungal biomass and trichothecene content were positively correlated in both natural infected and artificially inoculated plants (Table 2). In emmer grains the correlations between Fusarium DNA from F. graminearum and F. culmorum and total toxin amounts were stronger (Figure 1) than in grains of the naked barley cultivars (Figure 2). However, the F. graminearum and F. culmorum contents in the naked barley reported here were underestimated (see Material and methods) in comparison to emmer and wheat.

Table 2 Correlation (r) and significance (p) of correlation between the different parameters in grain and glume in naturally and artificially infected samples

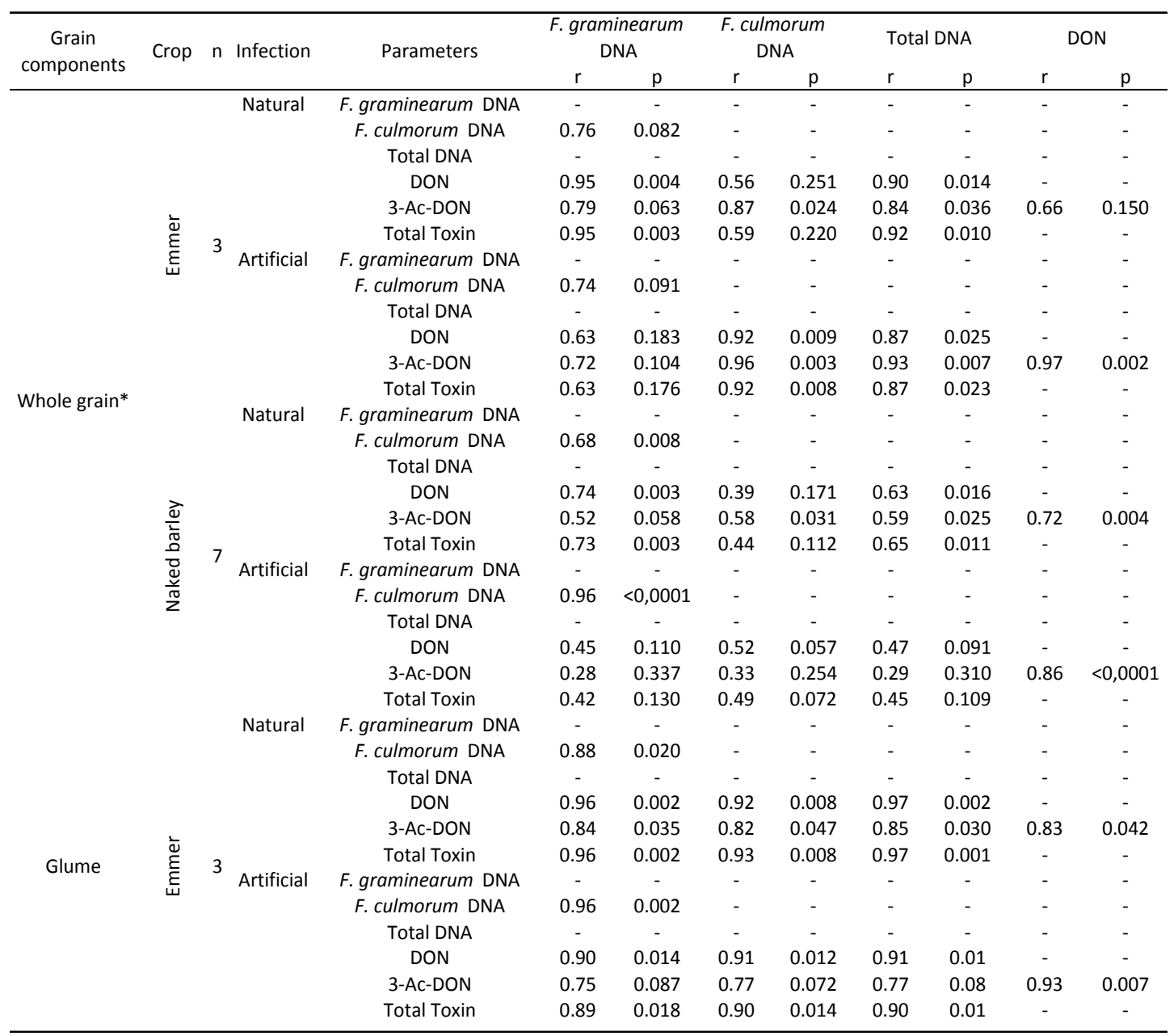

n: number of cultivars, * emmer and naked barley without glumes 
In the emmer glume, the total fungal DNA content correlated well with its trichothecene content (Table 2). When the DNA was examined separately for F. graminearum and $F$. culmorum, the results showed that in the naturally infected cereals the mycotoxin content of the grain correlated well with $F$. graminearum colonization but less with $F$. culmorum colonization (Table 2). The artificial infection led to a more equal ratio of the two fungi in the glume (Table 1), so that the correlation between the mycotoxin content and the DNA was high for both fungi (Table 2 and Figure 3).

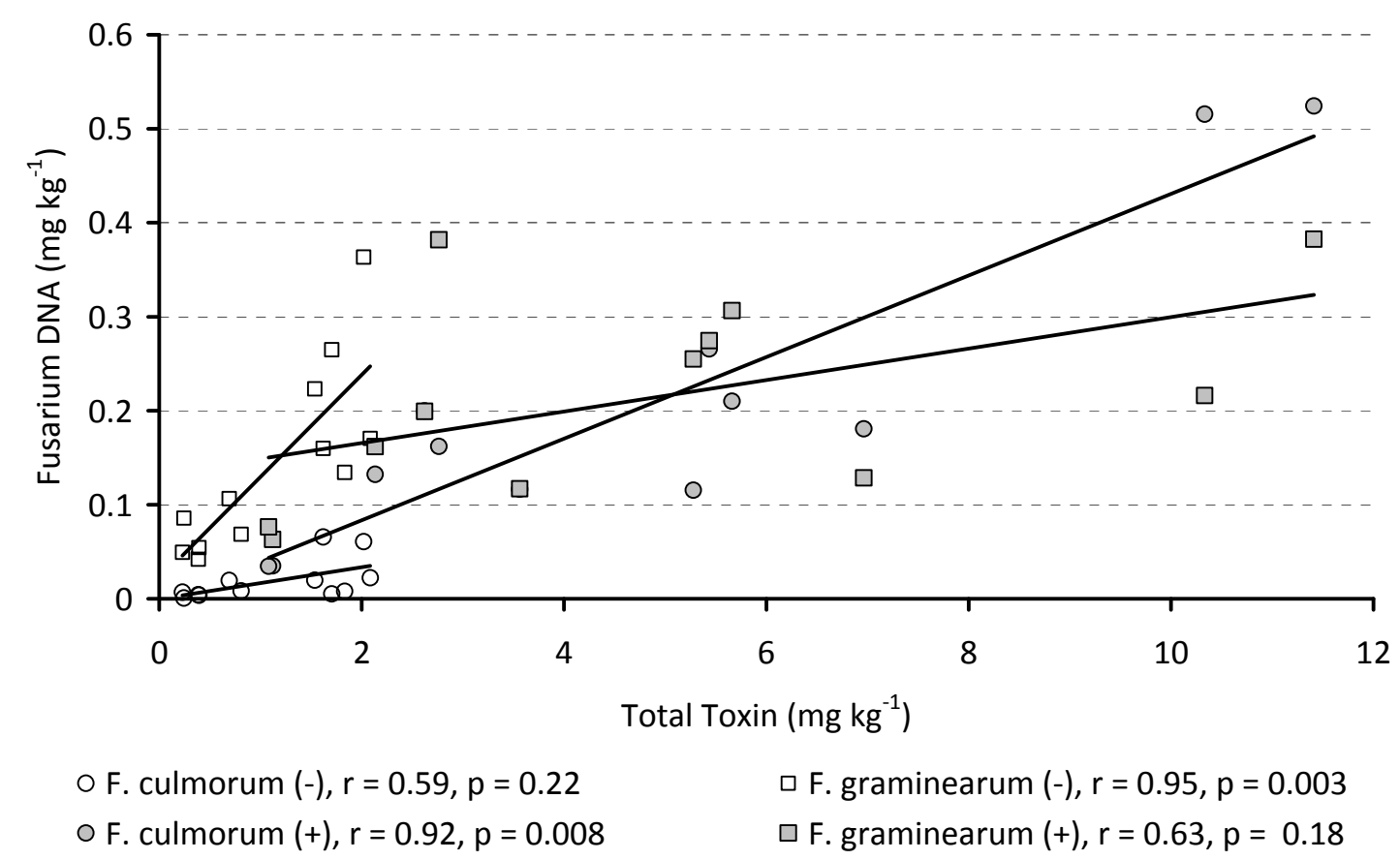

Figure 1 Correlation between total Fusarium DNA and total toxin content (DON+3-AcDON) in emmer grains $(n=3)$ after natural $(-)$ and artificial $(+)$ infection 


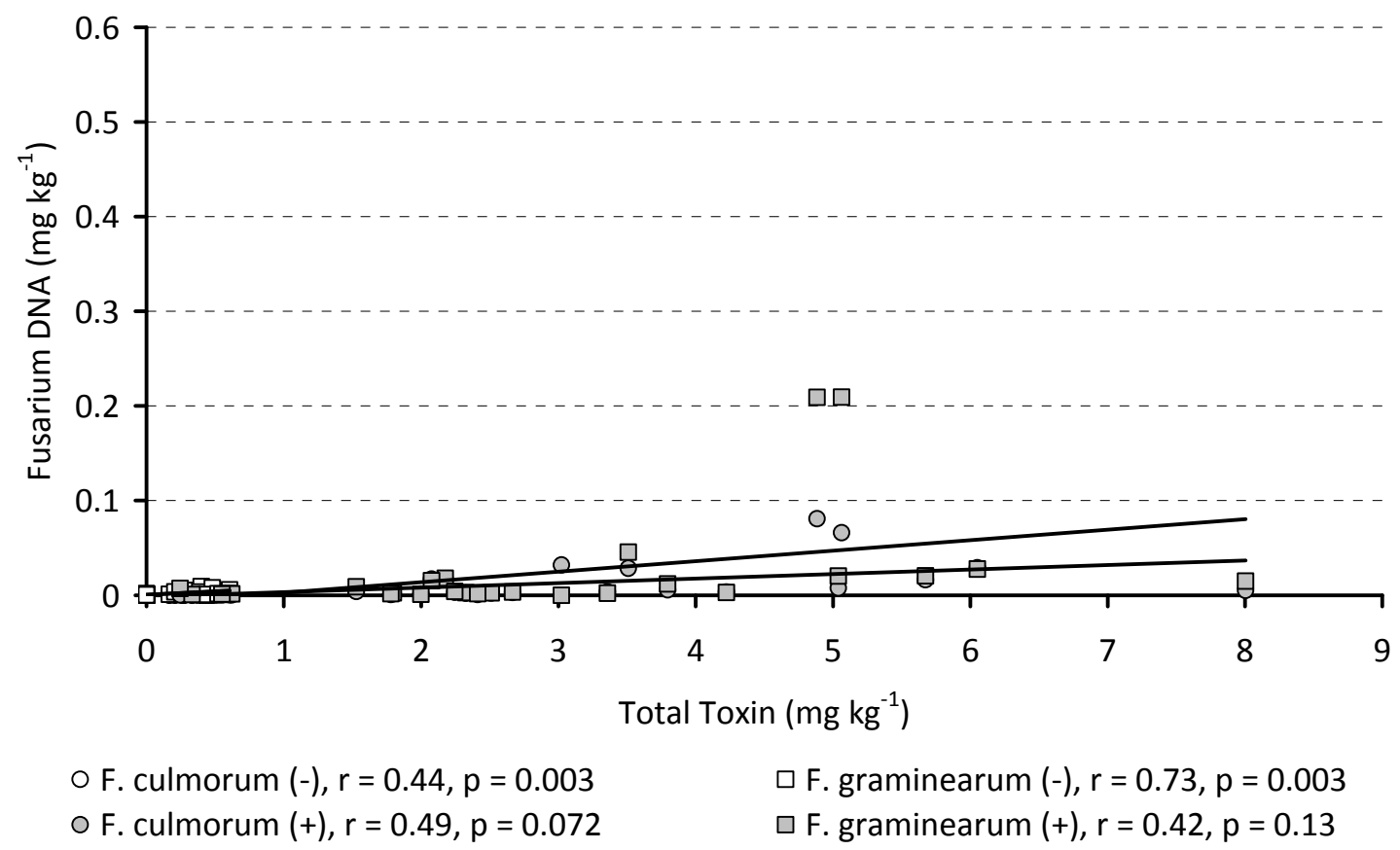

Figure 2 Correlation between total Fusarium DNA and total toxin content (DON/3-AcDON) in flour made from naked barley $(n=7)$ after natural $(-)$ and artificial $(+)$ infection

The content of Fusarium DNA and trichothecenes in the glume was closely significant correlated in the naturally infected samples (natural infection: $\mathrm{r}=0.98, \mathrm{p}=0.001$; artificial infection: $\mathrm{r}=0.76, \mathrm{p}=0.083$ ), and the total toxin content was significantly correlated in the artificially infected samples (natural infection: $r=0.77, p=0.075$; artificial infection: $r=0.89, \mathrm{p}=0.017$ ). The comparison of Fusarium DNA with the total toxin content showed a higher content of fungal biomass in the infected wheat cultivar compared to the emmer cultivars, but the levels of trichothecenes in wheat were lower (Table 1). 
Table 3 Relative proportion (\%) of Fusarium graminearum and Fusarium culmorum DNA, and total toxin (DON + 3-Ac-DON) in emmer glume in comparison to the grain

\begin{tabular}{llccc}
\hline \multirow{2}{*}{ Parameter } & Infection & Linie-9-102 & Far-108+Hein-101 & Klein \\
\hline \multirow{2}{*}{ F. graminearum } & Natural & 85 & 80 & 82 \\
& Artificial & 85 & 85 & 82 \\
F. culmorum & Natural & 85 & 74 & 80 \\
& Artificial & 73 & 83 & 80 \\
Total Toxin & Natural & 77 & 67 & 69 \\
& Artificial & 72 & 77 & 79 \\
\hline
\end{tabular}

The artificially infected emmer and naked barley cultivars showed in comparison to the naturally infected samples a higher variation in DON and 3-Ac-DON content (data not shown). Emmer showed here, despite a lower number of investigated cultivars (emmer $=3$; naked barley $=7$ ) on the two locations, a higher variance in its DON content and higher DON accumulation in comparison to naked barley in both the naturally and artificially infected samples.

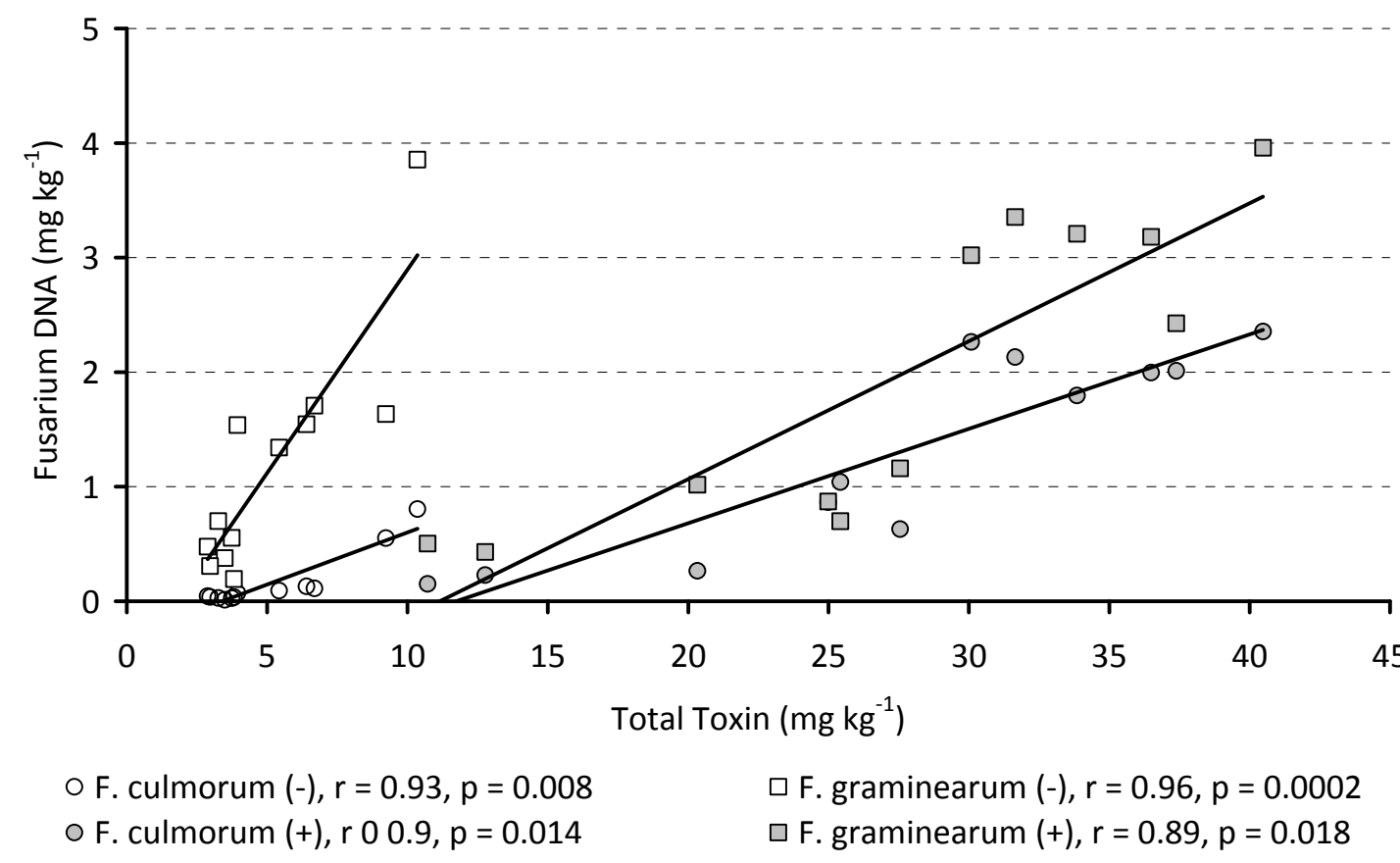

Figure 3 Correlation between total Fusarium DNA and total toxin content (DON/3-AcDON) in flour made from emmer glume $(n=3)$ after natural $(-)$ and artificial $(+)$ infection 
The comparison of the amounts of F. graminearum DNA and F. culmorum DNA in the grain flour revealed F. graminearum as the dominant species (Figure 4) in the naturally infected samples. This dominance was very clear as about $90 \%$ of the detected Fusarium DNA was of F. graminearum origin. In comparison, in the artificially infected emmer and naked barley samples, the relative content of F. graminearum DNA was about $60 \%$. Artificially infected emmer grain showed a higher F. culmorum content compared to emmer glume (45\%) and naked barley (39\%), but the difference was not significant.

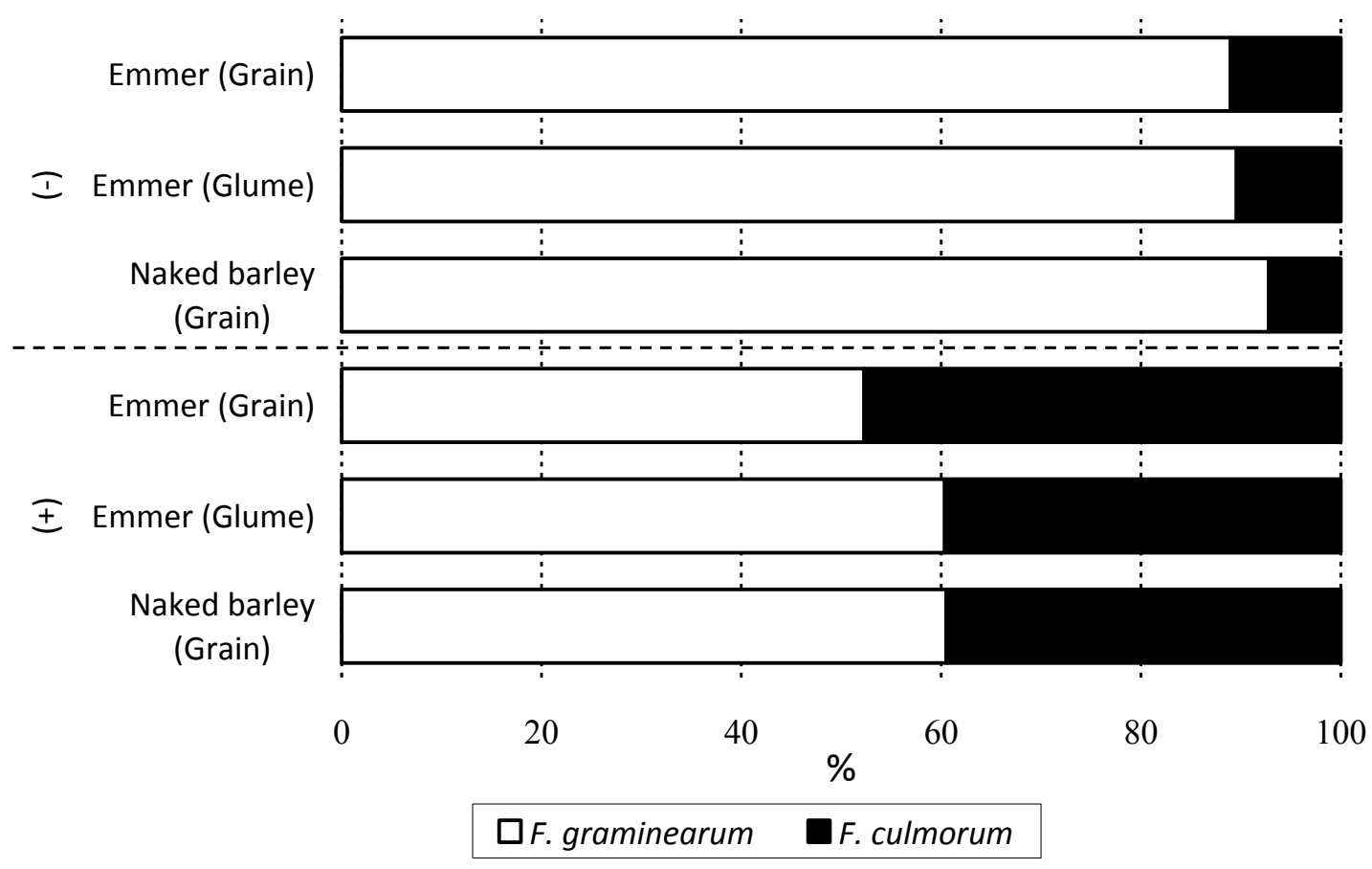

Figure 4 Percentage of F. graminearum and F. culmorum in naturally (-) and artificially $(+)$ infected grain and glume

The quantification of DON and 3-Ac-DON (Table 1) revealed that DON was dominant in all investigated samples (Figure 5). The ratio of both mycotoxins (about $90 \%$ was DON) was similar in both the naturally and artificially infected samples. The content of both trichothecenes was highly correlated in the emmer grain $(r=0.84, p=0.04)$ and glume $(r=0.99, p=0.02)$. The emmer grain had a lower relative 3-Ac-DON content compared to naked barley grain and emmer glume (60\% and $50 \%$, respectively). In relation to these results, the higher relative quantities of F. graminearum (Figure 4) led to a higher 3-Ac-DON content (Figure 5), which was also reflected by both the $F$. graminearum/F. culmorum and DON/3-Ac-DON ratios (Table 1). 


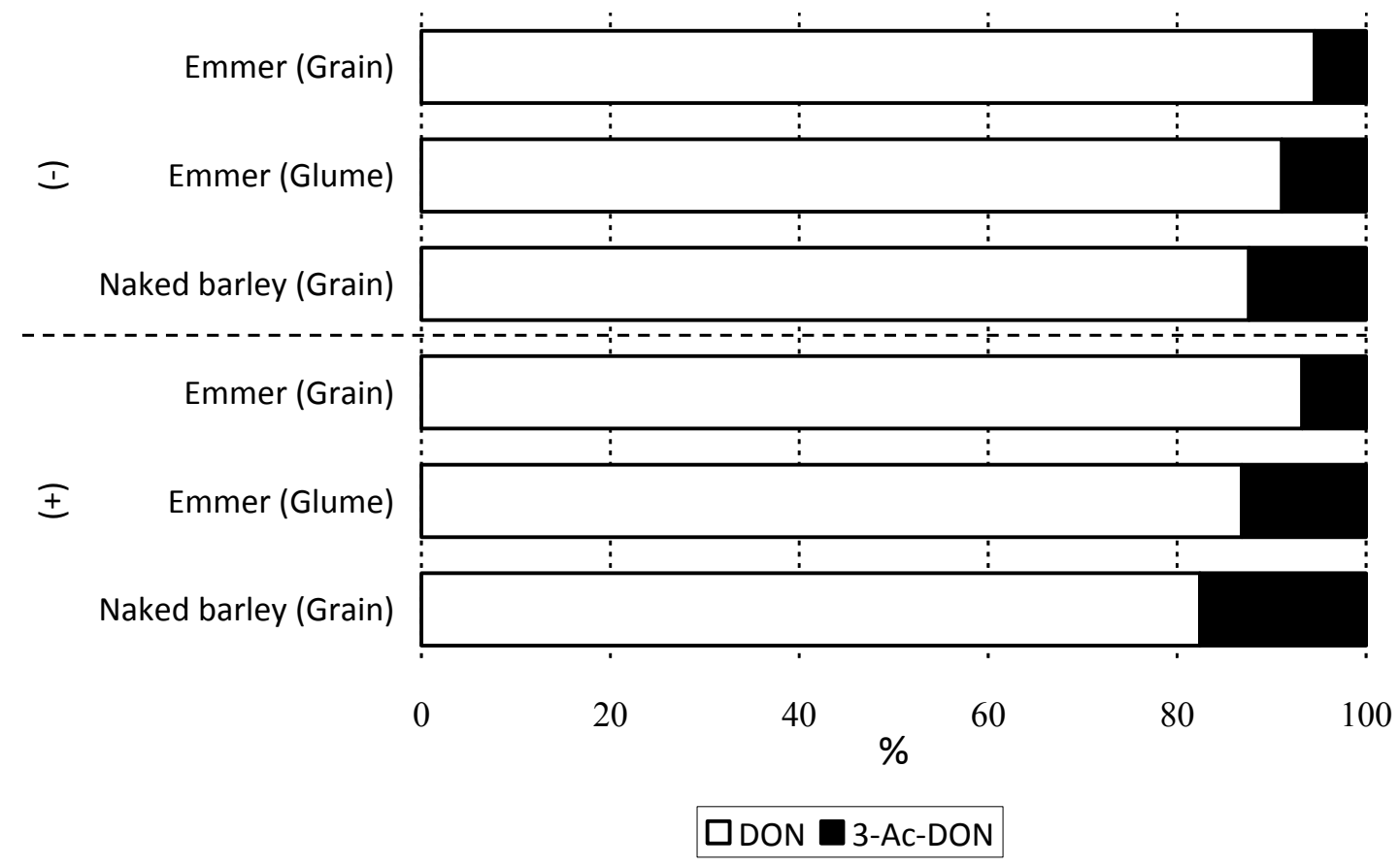

Figure 5 Percentage of deoxynivalenol (DON) and 3-acetyl-deoxynivalenol (3-AcDON) of total toxin in naturally (-) and artificially $(+)$ infected grain and glume flour In emmer, most of the Fusarium DNA and trichothecenes accumulated in the glume (Table 3). However, the relative total toxin content in the glume was lower than that found in the grain (9.5\% F. graminearum $5.7 \%$ F. culmorum $)$. As a consequence, there was a higher relative trichothecene content in the grain.

\section{Discussion}

Under the field conditions of the present study, F. graminearum was the predominant species for FHB and the major producer of trichothecenes in all cereals and their cultivars (Table 1). After artificial inoculation with a mixture of $F$. graminearum and $F$. culmorum conidia, both species colonized the grain to a comparable extent. The highest DON contents were found in emmer grains both after natural and artificial infection, indicating that this ancient crop is more susceptible to FHB than wheat, barley or naked barley. This result corroborated the results of other studies which reported a high susceptibility of many emmer cultivars to Fusarium infection (Buerstmayr et al. 2003, Oliver et al. 2007). However, emmer cultivars with a low sensitivity to FHB have been described, too (Buerstmayr et al. 2003, Oliver et al. 2007), though none of the cultivars tested in our study belonged to this category. The naked barley (hull-less barley) cultivars used in this study were less sensitive to infection with Fusarium than either the emmer or wheat, with the exception of the cultivars Lawina and Linz. The other five 
hull-less cultivars (Frealishe, Yonas, ZFS, Taiga and 00/900/5N) had a sensitivity similar to that of the summer (hulled) barley cv. Barke (data not shown). The glume appeared to act as a barrier for the fungus in the summer barley because most of the fungus biomass and trichothecenes accumulated in the glume (Table 1), similar to the situation in earlier reports (Abebe et al. 2004). However, the lack of glume could not have been the only reason for the hull-less barley's low susceptibility because, as said above, five of the naked barley cultivars had a similar susceptibility to the hulled cultivar used in our study. The limited role of glume as a factor controlling resistance to Fusarium was supported by the data obtained for emmer. Although emmer possesses strong glumes, it was the most susceptible cereal in our trials. There can also be explanations other than the presence or absence of glume for the differences in susceptibility between emmer and barley. The closed-flowering type of barley grain compared to wheat reported in the literature could be a reason for the lower degree of infection success of Fusarium spp. seen in the naked barley in comparison to the emmer and wheat in the present study (Boddu et al. 2006, Yoshida et al. 2007). In addition, in contrast to the established viewpoint, our results indicate that the infection of cereal grain with Fusarium spp. can occur not only via the stigma during the period of flowering. As shown by other authors in vitro, "secondary infection" may occur after flowering by the fungus growing on the glume and from the glume into the grain (Kang and Buchenauer 2000). The reasons for the good correlation between the Fusarium protein, Fusarium DNA and trichothecene concentration observed in grains and glumes (Table 2) may be either the growth of the fungus from the inner side of the glume to the outside after infection at flowering or the growth via the glume into the inside of the grain. Particularly, growth from the glume into the inner part of the grain would provide the fungus with substrates of higher protein, sugar and fatty acid content.

In the literature, wheat is reported to show a good correlation between its DON content and Fusarium DNA content with a ratio 1:3 (Schnerr et al. 2002). Our results confirm these data as we found ratios of DON to Fusarium DNA of 1:5 in the artificially infected wheat and 1:2 in the naturally infected wheat (Table 1). In contrast, we found a ratio of 1:10 in the artificially infected emmer. Barley, on the other hand, is reported to have fluctuating and generally lower ratios than wheat (Sarlin et al. 2006). This was substantiated by our results as the ratio was only 1:80 in artificially infected barley (Table 1). We also observed a high fluctuation of these values among the cultivars: from 
a ratio of 1:60 for the naked barley cultivar Yonas to $1: 400$ for cultivar 00/900/5N (data not shown).

A possible reason for the lower ratios and higher fluctuations in barley grain in comparison to emmer and wheat may be the different chemical composition of their grains (Bhatty 1999). For instance, B-glucans, which are known to retard other components of grain flour, are found in relatively high concentrations in barley grain $(5.0 \%)$ in comparison to wheat $(0.5 \%)$ (Bhatty 1999). Additionally, defence response products, such as protease inhibitors, or secondary metabolites such as phenols (Eggert et al. 2010) may also affect the amount of trichothecenes produced by Fusarium spp. in grains (Boutigny et al. 2008, Dixon 2001, Geddes et al. 2008). Furthermore, certain components in the grain may cause interference with the analytical methods. For example, we observed an inhibition of DNA amplification by extracts of naked barley and an additional purification step with spermin precipitation was needed to overcome this effect. The component of barley grains that might be responsible for DNA polymerase inhibition are the aforementioned soluble ß-glucans (Bhatty 1999).

A reason for the higher DON/DNA ratio (Table 1) in emmer in comparison to wheat may be the inability of emmer to glycosylate DON. Glycosylation is a detoxification mechanism and a resistance factor known to occur in wheat (Boutigny et al. 2008, Poppenberger et al. 2003). DON glycosylation may, therefore, lower the DON/DNA ratio in wheat compared to emmer (Table 1). We hypothesize that emmer cannot glycosylate DON, which would explain both the high sensitivity of emmer to Fusarium infection and its high DON content.

Both 3-Ac-DON and 15-Ac-DON are biosynthetic precursors of DON (Kimura et al. 2001). In the present study, the 3-Ac-DON content of the cereals was closely correlated with the DON content, whereas no 15-Ac-DON could be detected. A weaker correlation between the DON content and 3-Ac-DON in the naturally infected samples in comparison to the artificial infection can be explained by the presence of heterogeneous and fluctuating mixed populations of 3-Ac-DON chemotypes in the field (Bottalico and Perrone 2002, Foroud and Eudes 2009). In contrast, all the artificial infections were performed with the same identically mixed inoculum. The higher relative concentration of 3-Ac-DON in the samples with a stronger F. graminearum dominance (Figs. 4, 5) can possibly be explained by the difference in the occurrence of 3-Ac-DON chemotypes between F. graminearum and F. culmorum in our fields (Table 1). 
Both Fusarium species colonized predominantly the glumes (Table 1). The amount of Fusarium DNA was five times higher in the glume than in the grain, although the glume made up only $30 \%$ of the mass of the whole glume and grain (ratios of this study, data not shown). The trichothecenes were predominantly located in the glumes, too. The trichothecene-to-DNA ratios in the glumes were lower than in the grain (Table 1), indicating that the trichothecenes diffuse along the concentration gradient in the plant tissue (Table 3). It is more than likely that wet conditions would foster this translocation (Cowger et al. 2009). Therefore contrary to the conventional idea of "secondary infection" leading to DON accumulation in harvested grains, this diffusion could be the cause of DON accumulation in the grain, an idea supported by the correlation between the DNA and toxin found in the present study (Table 2).

As the difference between the concentration of DON in the glumes and in the grains remained large, the diffusion of this trichothecene appears to be limited by the free water content in the ripening cereal kernels. Alternatively, the difference between the partition of Fusarium biomass and trichothecenes between the glumes and grains could be explained by differences in the production of trichothecenes. This latter hypothesis can be tested in the future by comparing the expression of Tri5 and other genes of the trichothecene pathway in the two tissues.

In conclusion, we showed that emmer was highly susceptible to F. graminearum and $F$. culmorum infection and trichothecene accumulation, while naked barley had a relatively low susceptibility. Most of the fungal biomass and trichothecenes were located in the glume in the emmer and summer barley. Although naked barley does not possess this protective organ, it was in general less susceptible to Fusarium infection than emmer. Further investigations will focus on the sensitivity and defence mechanisms against Fusarium infection in emmer and naked barley.

\section{Acknowledgments}

This work is part of the FAEN Joint Project 3 "Quality-related plant production under modified basic conditions: mycotoxins in the context of production, quality and processing", financed by the Ministry of Science and Culture of Lower Saxony, Germany. Special thanks are extended to the growers who provided the seeds for this research trial: Dr. Karl-Josef Müller, Getreidezüchtungsforschung Darzau; Eckard Irion, Verein für Pflanzenzucht Hof Grub e.V.; Dr. Claus Einfeldt, Saatzucht Ackermann; and Hans-Werner Klein, UGB Gesundheitsförderung. 


\section{References}

Abebe, T., Skadsen, R. W. \& Kaeppler, H. F. (2004) Cloning and identification of highly expressed genes in barley lemma and palea. Crop Science, 44:942-950.

Adejumo, T. O., Hettwer, U. \& Karlovsky, P. (2007) Occurrence of Fusarium species and trichothecenes in Nigerian maize. Int. J. Food Microbiol., 116:350-357.

Beyer, M., Klix, M. B., Klink, H. \& Verreet, J. A. (2006) Quantifying the effects of previous crop, tillage, cultivar and triazole fungicides on the deoxynivalenol content of wheat grain - a review. Journal of Plant Diseases and Protection, 113:241-246.

Bhatty, R. S. (1999) The potential of hull-less barley. Cereal Chemistry, 76:589-599.

Boddu, J., Cho, S., Kruger, W. M. \& Muehlbauer, G. J. (2006) Transcriptome analysis of the barley-Fusarium graminearum interaction. Molecular Plant-Microbe Interactions, 19:407-417.

Bottalico, A. \& Perrone, G. (2002) Toxigenic Fusarium species and mycotoxins associated with head blight in small-grain cereals in Europe. European Journal of Plant Pathology, 108:611624.

Boutigny, A. L., Richard-Forget, F. \& Barreau, C. (2008) Natural mechanisms for cereal resistance to the accumulation of Fusarium trichothecenes. European Journal of Plant Pathology, 121:411-423.

Brandfass, C. \& Karlovsky, P. (2006) Simultaneous detection of Fusarium culmorum and Fgraminearum in plant material by duplex PCR with melting curve analysis. BMC Microbiology, 6.

Brandfass, C. \& Karlovsky, P. (2008) Upscaled CTAB-Based DNA Extraction and Real-Time PCR Assays for Fusarium culmorum and F. graminearum DNA in Plant Material with Reduced Sampling Error. Int. J. Mol. Sci., 9:2306-2321.

Buerstmayr, H., Stierschneider, M., Steiner, B., Lemmens, M., Griesser, M., Nevo, E. \& Fahima, T. (2003) Variation for resistance to head blight caused by Fusarium graminearum in wild emmer (Triticum dicoccoides) originating from Israel. Euphytica, 130:17-23.

Cowger, C., Patton-Ozkurt, J., Brown-Guedira, G. \& Perugini, L. (2009) Post-Anthesis Moisture Increased Fusarium Head Blight and Deoxynivalenol Levels in North Carolina Winter Wheat. Phytopathology, 99:320-327.

Degaonkar, A. M., Tamhankar, S. A. \& Rao, V. S. (2005) An assessment of cultivated emmer germplasm for gluten proteins - Polymorphism of gluten proteins in cultivated emmer germplasm. Euphytica, 145:49-55.

Dixon, R. A. (2001) Natural products and plant disease resistance. Nature, 411:843-847.

Eggert, K., Hollmann, J., Hiller, B., Kruse, H. P., Rawel, H. M. \& Pawelzik, E. (2010) Effects of Fusarium Infection on the Phenolics in Emmer and Naked Barley. Journal of Agricultural and Food Chemistry, 58:3043-3049.

Eriksen, G. S. \& Pettersson, H. (2004) Toxicological evaluation of trichothecenes in animal feed. Animal Feed Science and Technology, 114:205-239.

Foroud, N. A. \& Eudes, F. (2009) Trichothecenes in Cereal Grains. Int. J. Mol. Sci., 10:147173.

Geddes, J., Eudes, F., Laroche, A. \& Selinger, L. B. (2008) Differential expression of proteins in response to the interaction between the pathogen Fusarium graminearum and its host, Hordeum vulgare. Proteomics, 8:545-554.

Han, Z. X., Qian, G., Wu, F., Pan, Z. F., Deng, G. B. \& Yu, M. Q. (2008) Sequences variation and classification of B-hordein genes in hull-less barley from the Qinghai-Tibet Plateau. Molecular Biology, 42:56-63.

Helm, C. V. \& de Francisco, A. (2004) Chemical characterization of Brazilian hulless barley varieties, flour fractionation, and protein concentration. Sci. Agric., 61:593-597. 
Hoppes, B. \& Mc Clure, W. (1981) Studies on the selectivity of DNA precipitation by spermine. Nucleic Acids Reasearch, 9:5493-5504.

Kang, Z. S. \& Buchenauer, H. (2000) Cytology and ultrastructure of the infection of wheat spikes by Fusarium culmorum. Mycological Research, 104:1083-1093.

Kimura, M., Anzai, H. \& Yamaguchi, I. (2001) Microbial toxins in plant-pathogen interactions: Biosynthesis, resistance mechanisms, and significance. J. Gen. Appl. Microbiol., 47:149-160.

Klix, M. B., Beyer, M. \& Verreet, J. A. (2008) Effects of cultivar, agronomic practices, geographic location, and meteorological conditions on the composition of selected Fusarium species on wheat heads. Can. J.of Plant Pathol.-Rev. Can. De Phytopathol., 30:46-57.

Nielsen, C. C., M. Didier, A. Dietrich, R. Märtlbauer, E. (2009) Trichothecene-induced cytotoxicity on human cell lines Mycotoxin Research 25:77-84.

Oliver, R. E., Stack, R. W., Miller, J. D. \& Cai, X. (2007) Reaction of wild emmer wheat accessions to Fusarium head blight. Crop Science, 47:893-899.

Parry, D. W., Jenkinson, P. \& McLeod, L. (1995) Fusarium ear blight (SCAB) in small-grain cereals - a review. Plant Pathol., 44:207-238.

Pekkarinen, A. I., Longstaff, C. \& Jones, B. L. (2007) Kinetics of the inhibition of Fusarium serine proteinases by barley (Hordeum vulgare L.) inhibitors. Journal of Agricultural and Food Chemistry, 55:2736-2742.

Poppenberger, B., Berthiller, F., Lucyshyn, D., Sieberer, T., Schuhmacher, R., Krska, R., Kuchler, K., Glossl, J., Luschnig, C. \& Adam, G. (2003) Detoxification of the Fusarium mycotoxin deoxynivalenol by a UDP-glucosyltransferase from Arabidopsis thaliana. J. Biol. Chem., 278:47905-47914.

Sarlin, T., Yli-Mattila, T., Jestoi, M., Rizzo, A., Paavanen-Huhtala, S. \& Haikara, A. (2006) Real-time PCR for quantification of toxigenic Fusarium species in barley and malt. European Journal of Plant Pathology, 114:371-380.

Schnerr, H., Vogel, R. F. \& Niessen, L. (2002) Correlation between DNA of trichotheceneproducing Fusarium species and deoxynivalenol concentrations in wheat-samples. Lett. Appl. Microbiol., 35:121-125.

Thuvander, A., Wikman, C. \& Gadhasson, I. (1999) In vitro exposure of human lymphocytes to trichothecenes: Individual variation in sensitivity and effects of combined exposure on lymphocyte function. Food and Chemical Toxicology, 37:639-648.

Yabe, T., Hashimoto, H., Sekijima, M., Degawa, M., Hashimoto, Y., Tashiro, F. \& Ueno, Y. (1993) Effects of Nivalenol on Hepatic Drug-Metabolizing Activity in Rats. Food and Chemical Toxicology, 31:573-581.

Yang, L., van der Lee, T., Yang, X., Yu, D. \& Waalwijk, C. (2008) Fusarium populations on chinese barley show a dramatic gradient in mycotoxin profiles. Phytopathology, 98:719-727.

Yazar, S. \& Omurtag, G. Z. (2008) Fumonisins, Trichothecenes and Zearalenone in Cereals. Int. J. Mol. Sci., 9:2062-2090.

Yoshida, M., Kawada, N. \& Nakajima, T. (2007) Effect of infection timing on fusarium head blight and mycotoxin accumulation in open- and closed-flowering barley. Phytopathology, 97:1054-1062. 



\title{
5.2 Effects of Fusarium Infection on the Phenolics in Emmer and Naked Barley
}

Kai Eggert, Jürgen Hollmann, Beate Hiller, Hans-Peter Kruse, Hashadrai M. Rawel, Elke Pawelzik, Journal of Agricultural and Food Chemistry (2010), 58:3043-3049

\begin{abstract}
Inoculated or non- inoculated naked barley and emmer cultivars were investigated with regard to their influence on phenolic acid profiles and their arabinoxylan content. Two groups of phenolic compounds were differentiated - methanol-soluble and hydrolysable covalent-bound phenolic compounds. Chromatographic methods were applied for their analysis. The results showed ferulic acid as the predominant phenol in both total and covalent-bound fractions. The innoculation significantly reduced the ferulic acid content within a range of $5.6-6.6 \%$ in the two cereals and all their cultivars. Naked barley cultivars additionally contained the flavonoid catechin in the soluble fraction. The innoculation led here to a significant increase in the catechin content of about $4.5 \%$. These results document an induction of the synthesis of catechin in naked barley after artificial Fusarium infection, whereas the ferulic acid content declined.
\end{abstract}

Keywords: fusarium infection; phenolic acids; arabinoxylan; trichothecenes

\section{Introduction}

Fusarium graminearum and Fusarium culmorum infection of cereal grains leads to pathogenic effects on the plant and spike in wheat, barley and emmer (1-4). These effects can result in yield loss and quality reduction $(1,5)$. Fusarium head blight (FHB) is the visible effect of this fungal infection first recorded by Worthington G. Smith in 1884 and represents a problem known worldwide (1-4).

The Fusarium species, F. graminearum and F. culmorum, are producers of various trichothecene mycotoxins including deoxynivalenol (DON), its precursors 3- and 15acetyldeoxynivalenol (3-Ac-DON and 15-Ac-DON), and other compounds (1). DON is a potential inhibitor of protein biosynthesis. In mammals, DON leads to unspecific effects in the intestines causing diarrhoea with vomiting, a reduced food intake and raised bleeding tendency in the intestines. Its specific effects are a reduced leukocyte content connected with a loss of immune function and a rise in free radicals in the liver (6-9). These negative effects underline the necessity of reducing the infection-derived effects of Fusarium spp. on food and feed. This problem has been addressed effectively 
by limiting the maximum amount of DON by a threshold value in the European Union for products destined for human (10) and animal nutrition [(EG) Nr. 576/2006. 2006].

The main phenol in cereal grains is the cinnamic-acid derivate ferulic acid, whereas other phenolic acids like caffeic acid or $p$-coumaric acid are also found in lower concentrations (10-13). In monocotyledons, ferulic acid is incorporated into plant cell wall structures. Ferulic acid provides crosslinkages via ester bonds between arabinoxylans (AX) and other cell wall components such as cellulose, lignin and proteins (14-18).

For artificially inoculated wheat grains existing data showed a significant reduction of ferulic and p-cumaric acid. Concentrations of ferulic acid measured during grain development attained similar values in both resistant and susceptible cultivars (19). In a further study different wheat cultivars were evaluated on basis of the distinction in FHB-resistant and FHB-susceptible cultivars derived from FHB disease incidence and severity data (13). However, not any differences in the content of free and bound phenolic acids in FHB-resistant and FHB-susceptible cultivars were found (13). Previous studies with artificially inoculated maize grains showed a negative correlation between the extent of exposure to F. graminearum and the ferulic acid content in the pith tissue, but the different genotypes did not show any correlation with regard to their resistance and/or susceptibility to F. graminearum and the corresponding content of phenolic compounds (12).

Barley grains contain, in addition to cinnamic acid derivates, phenols of the flavonoid group, especially those belonging to the proanthocyanidin group (20). Additionally, some coloured cultivars contain anthocyanidins (21). Catechin is the most commonly described flavonoid present in barley. All these soluble phenolic compounds are known to have protective effects against pathogen infection, UV irradiation or oxidative stress and these effects indirectly reflect the resistance of the plant against stress (22). Flavan derivates have been described as inducible antimicrobial metabolites in rice as phytoalexins (23). The proanthocyanidins found in barley are oligomers of epicatechin and gallocatechin. They have antioxidant and radical scavenging activities, and are capable of metal complexation, of exhibiting antimicrobial properties and of having an affinity for proteins resulting in enzyme inhibition and/or protein precipitation (24). The combination of these properties of phenolic compounds and their participation in the 
strengthening of the cell wall material therefore illustrates their role in the defence response of the plants against pathogenic infection.

Emmer (Triticum dicoccum) and naked barley (hull-less barley, Hordum vulgare var. nudum) cultivars are usually grown in organic farming systems and, do date, no data exist about their behaviour under conventional farming conditions. In addition, not much data are available on the potential effects of Fusarium infections on the phenolic compound profile in the grains of these cereals. More knowledge about the interaction between the fungus and grain phenolics production can contribute to better understanding the mechanisms involved in the reaction of the plant hosts and thereby providing a criteria for determination of their susceptibility to pathogenic infection.

The present study focuses on the profiling of phenolics in emmer and naked barley grains after infection by Fusarium spp. In an earlier study the total content of phenolics was determined (19) but in the present investigation it was intended to fractionate the phenolic compounds in two groups, meaning free or soluble and those which are AX bound. Further, our objective was in comparison to previous studies, to study fully developed and harvested grains, reflecting a status after the complete Fusarium infection period (10). Moreover, we were interested in characterizing probable modifications of the phenolic compounds composition after Fusarium infection as a stress-induced response of the plant. This response is provoked by fungal metabolites, including effects on the plant cell wall structures, where phenolic compounds are incorporated. This data explains the role of phenolic compounds as a response to the Fusarium infection and as stress influenced molecules. We want to demonstrate possible defence mechanisms of grains, showing differences in these defence strategies between the species. Additionally we will discuss different phenol fractions, free and cell wall bound in connection to the fungal infection.

\section{Materials and Methods}

\section{Chemicals}

For toxin analysis all standard were purchased from Biopure Co.Ltd (Austria) as certified analytical standard. Reference compounds used for phenol quantification in the experiment are gallic acid (Sigma Aldrich); protocatechuic acid (Roth); $(+)$ catechin (Roth); vanillic, caffeic, ferulic, p-cumaric and salicylic acid (Roth); phloroglucinol (Fluka); pyrogallol (Fluka) and quercitin (Riedel-de-Häen). External standards for 
arabinose were D-(-)-arabinose and D-(+)-xylose (highest purity available; SigmaAldridge, Taufkirchen, Germany)

\section{Experimental design and sample preparation}

Three emmer cultivars and seven naked barley cultivars grown in 2007 with eight replications were randomized in two field trials (Reinshof $[\mathrm{RH}]$ and Sattenhausen $[\mathrm{SH}]$ ) in the centre of Germany near the city of Göttingen and were chosen for the analysis. The location conditions at Reinshof are $152 \mathrm{~m}$ above sea level, wind sheltered and dale area near a river border. The $\mathrm{N}_{\min }$ content was $145 \mathrm{~kg} \mathrm{ha}^{-1}$ recorded in $90 \mathrm{~cm}$ depth of the soil. At Sattenhausen, the conditions are $260 \mathrm{~m}$ above sea level, hilly and windy. The $\mathrm{N}_{\text {min }}$ content was $95 \mathrm{~kg} \mathrm{ha}^{-1}$ in $90 \mathrm{~cm}$ soil depth with an additional fertilization of $40 \mathrm{~kg} \mathrm{~N} \mathrm{ha}^{-1}$ two months after sowing.

In each block, the plants in the second row were artificially inoculated with a mixed DON-producing Fusarium culmorum and Fusarium graminearum spore suspension $\left(50 \mathrm{ml} / \mathrm{m}^{2} ; 1 \times 10^{5}\right.$ spores $\left./ \mathrm{ml}\right)$ for three to five times during flowering by spray inoculation. Three strains of both F. culmorum (FC34, FC35, FC36) and F. graminearum (FG142; FG143; FG144) were used for conidiospore production. The DON-producing strains were isolated from wheat spike in Bavaria and are reference stocks from the Division of Plant Pathology and Crop Protection at the Department of Crop Science of the Georg-August-University Göttingen.

After the harvest, the grains without inoculation (later termed as natural infection) and those with inoculation (later termed as artificial infection) from the respective plots (each four replications) in both field trials were mixed. The grains from the different plots were mixed to create conditions which are also found under normal harvesting conditions. Whole grain flour was milled with a Retsch Rotormill ZM 100 to a particle size of $0.5 \mathrm{~mm}$. These mixed grain flours were than used three times for sampling from different regions of the complete sample of each cultivar and growing region.

\section{HPLC-MS/MS of DON and 3-Ac-DON}

Sample preparation: Five grams of whole grain flour were extracted with $40 \mathrm{ml}$ of acetonitrile-water mixture (80:20) over night on a reciprocal shaker. The extracts were centrifuged for $12 \mathrm{~min}$ at 5,000 x g and $4 \mathrm{ml}$ of the supernatant were used for solidphase extraction according to the manufacturer's instructions (Bond-Elut Mycotoxin, Varian GmbH, Darmstadt, Germany). Two millilitres of the cleaned extract were 
evaporated to dryness under vacuum, redissolved in $200 \mu \mathrm{l}$ of methanol-water (50:50) containing $0.2 \mathrm{mM}$ ammonium acetate and applied for the analysis.

Analysis: For the HPLC-MS/MS, a Varian 1200L MS/MS system (Varian, Inc. CA, USA) equipped with a triple quadrupole mass spectrometer, two ProStar 210 liquid chromatographic pumps a 410 autosampler, and a 500 MS Ion Trap mass spectrometer with ESI interface was used. Ten microliters of the solution prepared as described above were injected onto a C18 column (100 x $2 \mathrm{~mm}, 3 \mu \mathrm{m}$ particle size $)$ filled with polar modified material (Polaris Ether, Varian GmbH, Darmstadt, Germany) and the analytes were eluted with a methanol-water gradient (15\% to $70 \%$ during $20 \mathrm{~min}$ ) containing 0.2 $\mathrm{mM}$ ammonium acetate at a flow rate of $0.2 \mathrm{ml} / \mathrm{min}$. DON and 3-Ac-DON were detected by tandem mass spectrometry as described previously (25). The other DON precursor, 15-Ac-DON, was not found in our samples. The peak intensity was used for the quantitative and qualitative analysis applying external standards (see Chemicals).

RP-HPLC of grain phenols

The analysis of the phenolic compounds was conducted according to a modified method of Kim et al. (2007) and Yu et al. (2001) (21, 26).

Sample preparation: The aqueous methanol-soluble phenolic acids were extracted consecutively three times $(15,15,10 \mathrm{ml}$ for $12 \mathrm{~h}, 3 \mathrm{~h}, 3 \mathrm{~h})$ in a 50-ml falcon tube from 2 $\mathrm{g}$ whole grain flour with $80 \%$ aqueous methanol containing $1 \%$ acetic acid at $20^{\circ} \mathrm{C}$. The sample solutions were centrifuged 3 times for $5 \mathrm{~min}$ at 4,000 rpm. The supernatants were pooled and freeze dried. The dried phenolic acids were re-suspended in $4 \mathrm{ml} 80 \%$ aqueous methanol containing $1 \%$ acetic acid and were stored at $-20^{\circ} \mathrm{C}$ until analysis. Just before performing the HPLC, the cold samples were centrifuged for $3 \mathrm{~min}$ at 6,000 rpm and the supernatant was transferred into a vial for injection (Figure 1). 


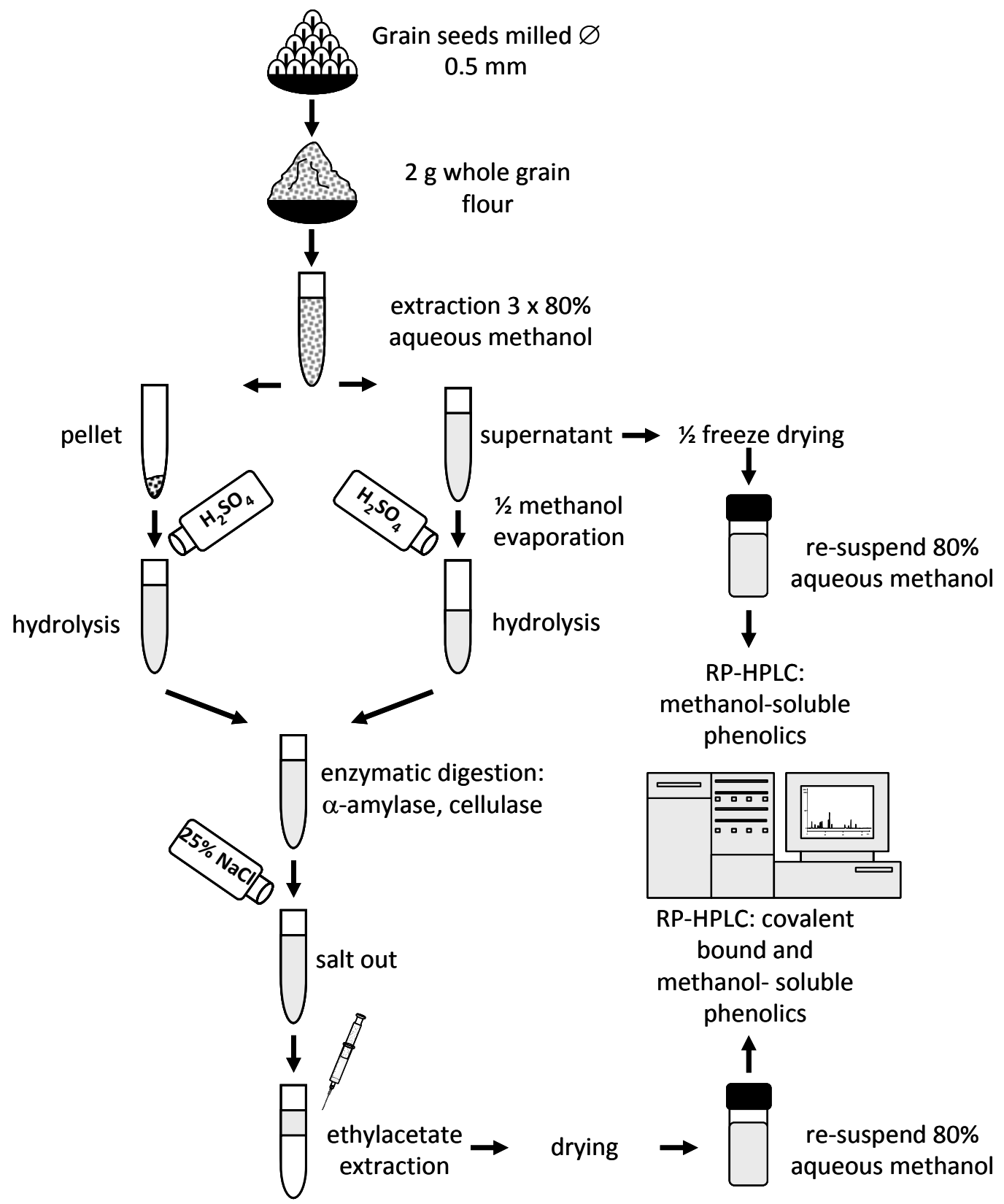

Figure 1 Extraction procedure of grain phenolics, separated procedures for the extraction of methanol-soluble phenolics and covalent bound phenolics for quantitative RP-HPLC. Aqueous methanol was made of $80 \%$ methanol with $20 \%$ dest. $\mathrm{H}_{2} \mathrm{O}(\mathrm{v} / \mathrm{v})$ containing $1 \%$ acetic acid, $20 \mathrm{ml} 0.1 \mathrm{M} \mathrm{H}_{2} \mathrm{SO}_{4}$ used for hydrolysis of covalent bound phenolics; $5 \mathrm{ml} 0.2 \mathrm{M} \mathrm{H}_{2} \mathrm{SO}_{4}$ used for hydrolysis of methanol-soluble phenolics, end concentration after re-suspension for analysis was $0.5 \mathrm{~g}_{\text {flour } \mathrm{ml}^{-1}}$

To compare the extraction using two different methods, this procedure was altered and the supernatant was divided into two: an aliquot of $20 \mathrm{ml}$ of the extract was freeze dried and in the case of the other $20-\mathrm{ml}$ aliquot, the methanol was evaporated at $100^{\circ} \mathrm{C}$ and 5 $\mathrm{ml} 0.2 \mathrm{M} \mathrm{H}_{2} \mathrm{SO}_{4}$, was added, followed by $1 \mathrm{~h}$ hydrolysis at $100^{\circ} \mathrm{C}$. The rest of the 
procedure followed the extraction of insoluble phenolic acids as described below (Figure 1).

The extraction of the covalently bound phenolic acids was performed for the pellet remaining from the aqueous methanol extraction (Figure 1) or by using $2 \mathrm{~g}$ of the whole grain flour directly. The first step involved the addition of $20 \mathrm{ml}$ of $0.1 \mathrm{M} \mathrm{H}_{2} \mathrm{SO}_{4}$ to the samples and $1 \mathrm{~h}$ hydrolysis at $100^{\circ} \mathrm{C}$. After cooling the extract down to room temperature, $5 \mathrm{ml} 1 \mathrm{M} \mathrm{Na}$ acetate solution ( $\mathrm{pH}$ 5.5) containing 3900 units $\alpha$-amylase (product code: 10065-10G, 30 Units/mg dry matter; Sigma Aldrich, Switzerland) were added, and incubated for $2 \mathrm{~h}$ at $30^{\circ} \mathrm{C}$. This treatment was followed by addition of $4 \mathrm{ml}$ $0.1 \mathrm{M} \mathrm{Na}$ acetate solution $(\mathrm{pH}$ 5.5) containing 94.4 units cellulase (product code: 22178-25G , 1.0 Units/mg dry matter; Sigma Aldrich, Switzerland) and incubated at $30^{\circ} \mathrm{C}$ for $18 \mathrm{~h}$. Finally, $6 \mathrm{ml} 25 \% \mathrm{NaCl}$ solution was added and the liberated phenols were extracted three times, each with $10 \mathrm{ml}$ ethylacetate. The ethylacetate fraction was pooled and dried under the extractor hood. The dried extract was re-suspended in $4 \mathrm{ml}$ $80 \%$ aqueous methanol containing $1 \%$ acetic acid and kept at $-20^{\circ} \mathrm{C}$ until analysis (Figure 1). Prior to HPLC, the cold samples were centrifuged for $3 \mathrm{~min}$ at $6,000 \mathrm{rpm}$ and the supernatant was transferred to a vial, ready for injection. All samples for phenol analysis were extracted three times for each location $(n=6$ extract replication) so that 18 replications for emmer and 42 replications for naked barley were possible.

Analysis: For the HPLC, a dual pump mode Shimadzu 10A system (Duisburg, Germany) with a LC18 column (precolumn: K2-02, 20 × 2.0 mm, Prontosil 120-5-C18 ace-EPS, $5 \mu \mathrm{m}$; separation column: Prontosil 120-3-C18 ace-EPS COL SC-150; Bischoff Analysentechnik und -Geräte GmbH, Leonberg, Germany) was used. The flow rate was $0.8 \mathrm{ml} / \mathrm{min}$ and detection was performed by UV detection at 280 and $325 \mathrm{~nm}$ with a column temperature of $40^{\circ} \mathrm{C}$. The eluents were $\mathrm{A}=2 \%$ acetic acid, $\mathrm{pH} 1.9$ and $\mathrm{B}$ $=$ methanol. The gradient was applied under the following conditions: $100 \%$ eluent $\mathrm{A}, 0$ min; 90\% eluent A, 2 min; 70\% eluent A, 35 min; 10\% eluent A, 50 min; $0 \%$ eluent A, $52 \mathrm{~min} ; 0 \%$ eluent $\mathrm{A}, 56 \mathrm{~min}$ and $100 \%$ eluent $\mathrm{A}, \quad 60-75 \mathrm{~min}$ (regeneration/equilibration). The injection volume of the samples was $20 \mu 1$. The quantification was performed using an external calibration with diluted standard solutions (range $12.5-200 \mu \mathrm{g} / \mathrm{ml}$ in $80 \%$ aqueous methanol). 


\section{HPAEC-PAD of arabinoxylans (AX)}

Sample preparation For the analysis of total AX, $25 \mathrm{mg}$ flour sample and $2 \mathrm{ml} 1 \mathrm{M}$ $\mathrm{H}_{2} \mathrm{SO}_{4}$ were incubated for $2 \mathrm{~h}$ in a $10-\mathrm{ml}$ screw-capped glass tube in a laboratory sand bath at $110^{\circ} \mathrm{C}$ in a drying oven. The samples were then cooled to room temperature in a water bath. In a following step, $2 \mathrm{ml} 2 \mathrm{M} \mathrm{NaOH}$ was added up to $\mathrm{pH} 7$ and the $\mathrm{pH}$ value was checked by a $\mathrm{pH}$-test paper (to confirm neutral conditions). The sample solution was than centrifuged for $5 \mathrm{~min}$ at 3,500 rev/min. The supernatant $(3 \mathrm{ml})$ was removed, mixed with $3 \mathrm{ml}$ yeast suspension (Saccharomyces cervisiae, Type II; Sigma-Aldrich, Taufkirchen, Germany at $25 \mathrm{mg} / \mathrm{ml}, \mathrm{pH} \mathrm{7}$ ) and incubated for $2 \mathrm{~h}$ at $37^{\circ} \mathrm{C}$, while being gently shaken in a water bath. Yeast was used to digest as well as to consume the glucose liberated to avoid any interference of xylose and arabinose detection. This was followed by the addition of $1.5 \mathrm{ml} 2 \mathrm{M}$ barium acetate $\left[\mathrm{Ba}\left(\mathrm{CH}_{3} \mathrm{COO}\right)_{2}\right]$. The sample was vortexed and centrifuged for $5 \mathrm{~min}$ at 3,500 rev $\mathrm{min}^{-1}$. An aliquot of the supernatant was diluted 1:100, filtered through a $0.45-\mu \mathrm{m}$ nylon filter and analyzed.

Analysis The subsequent HPLC was performed with a DIONEX BioLC 500 chromatography system (DIONEX GmbH, Germany); consisting of an auto sampler AS 50, an amperometrical detector ED 50 with PAD cell and 2 gradient pumps GS 50. The BioLC-system was operated by chromatography software Chromeleon 6.50 SP 7; (DIONEX GmbH, Germany). A CarboPac PA-1 precolumn, 50 mm x 2mm; (DIONEX $\mathrm{GmbH}$, Germany) and for separation a CarboPac PA-1 column $250 \mathrm{~mm}$ x $2 \mathrm{~mm}, 10 \mu \mathrm{m}$ (DIONEX GmbH, Germany) were used and operated at $25^{\circ} \mathrm{C}$ in a column oven. The mobile phases were $\mathrm{H}_{2} \mathrm{O}$ (solvent $\mathrm{A}$ ) and $0.1 \mathrm{M} \mathrm{NaOH}$ (solvent B). A $0.2 \mathrm{ml} / \mathrm{min}$ isocratic flow (A:B - 80:20) under helium was applied for 50 min and $25 \mu 1$ per sample were injected. A reference $\mathrm{Ag} / \mathrm{AgCl}$ electrode was used in combination with a working gold electrode for detection using the following pulse potential sequence and durations: +0.1 Volt $(\mathrm{V})$ for $0.40 \mathrm{~s},-2 \mathrm{~V}$ for $0.01 \mathrm{~s} ;+0.6 \mathrm{~V}$ for $0.01 \mathrm{~s}$; and $-0.1 \mathrm{~V}$ for $0.06 \mathrm{~s}$. The detector response for the external standards D-(-)-arabinose and D-(+)-xylose (highest available purity; Sigma-Aldridge, Taufkirchen, Germany) was linear in the concentration range of 0.5 to $20.0 \mathrm{mg} / \mathrm{L}\left(\mathrm{R}^{2}>0.95\right)$ and was used to determine the concentration in the samples using the following equation: $\mathrm{C}_{\text {arabinoxylans }}=0.88 \mathrm{x}$ $\left[C_{\text {arabinose }}+C_{x y l o s e}\right]$. To exclude arabinose and xylose from sources other than from AX, the factor of 0.88 given in the equation was introduced according to (Hollmann et al. 
(2005) (27). For testing the influence of the AX content from each species one emmer (Klein) an one naked barley (ZFS) cultivar were used representative for investigation.

Data analyses were performed using Microsoft Excel 2003 for mean values and standard deviation. SigmaPlot 10.0 was used for the correlation (r) and statistical significance (p).

\section{Results and Discussion}

Effects of Fusarium infection on the grain phenolics

The content of the Fusarium toxins DON and 3-Ac-DON in emmer and naked barley showed a significant increase in the grains of artificially infected plants in comparison to the grains of naturally infected plants (Table 1). The accumulation of these mycotoxins indicates that both types of cereal and all the tested cultivars are liable to a certain degree of infection, underlining their susceptibility to Fusarium spp. (4, 5, 28). The obtained data showed in part high standard deviations for both toxins and phenolics (Tables 1 and 2) due to the field trials at two separate locations and the different cultivars investigated within one species.

Table 1 Total Fusarium toxin content based on DON +3 -Ac-DON concentration in naturally and artificially infected emmer (three cultivars) and naked barley (seven cultivars) grains

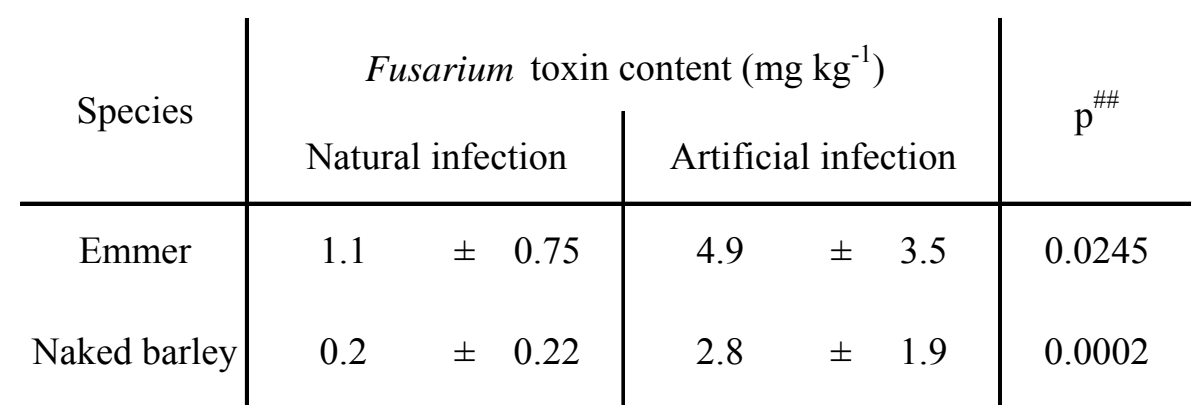

\#\# based on paired student t-test [emmer: $n=18$; naked barley: $n=42$ ]; data are presented as mean value \pm standard deviation; $p$ : significance

Phenolic compounds were detected in small amounts in the hydrolyzed methanolsoluble fraction. They mainly represented the cinnamic-acid derivates caffeic and ferulic acid (Table 3). These results confirm the literature data, where such hydroxycinnamates were also identified in the methanol-soluble fraction $(21,29)$. 
Table 2 Phenol content in grains of naturally and artificially Fusarium infected emmer (three cultivars) and naked barley (seven cultivars) samples: Fraction 1: methanol soluble $(80 \% \mathrm{MeOH}+1 \%$ acetic acid); Fraction 2: acid-enzyme hydrolysable $\left(\mathrm{H}_{2} \mathrm{SO}_{4} /\right.$ enzyme $)$

\begin{tabular}{|c|c|c|c|c|c|c|c|c|c|c|c|}
\hline \multirow{3}{*}{ Fraction } & \multirow{3}{*}{ Phenol } & \multicolumn{10}{|c|}{ Phenol content $\left(\mathrm{mg} \mathrm{kg}^{-1}\right)$} \\
\hline & & \multicolumn{5}{|c|}{ Emmer } & \multicolumn{5}{|c|}{ Naked Barley } \\
\hline & & \multicolumn{2}{|c|}{ Natural infection } & \multicolumn{2}{|c|}{ Artificial infection } & \multirow{2}{*}{$\frac{p^{\#}}{-}$} & \multicolumn{2}{|c|}{ Natural infection } & \multicolumn{2}{|c|}{ Artificial infection } & \multirow{2}{*}{$\frac{\mathrm{p}^{\# \#}}{0.046}$} \\
\hline 1 & Catechin & n.d. & \pm- & n.d. & $\pm \quad-$ & & 94.7 & \pm 34.1 & 99.3 & \pm 33.2 & \\
\hline \multirow{3}{*}{2} & Caffeic acid & n.d. $(3.2)^{\#}$ & \pm- & n.d. $(2.6)^{\#}$ & $\pm \quad-$ & - & 19.6 & \pm 2.4 & 18.6 & \pm 2.7 & $<0.001$ \\
\hline & Ferulic acid & 310.4 & \pm 12.7 & 292.9 & \pm 13.9 & $<0.001$ & 283.6 & \pm 32.7 & 264.9 & \pm 36.8 & $<0.001$ \\
\hline & $p$-Coumaric acid & 10.5 & \pm 3.6 & 9.6 & \pm 2.7 & 0.093 & 11.1 & \pm 5.5 & 11.1 & \pm 6.3 & 0.719 \\
\hline
\end{tabular}

n.d. = not detectable ${ }^{\#}$ data of cultivar "Klein"; "\# based on paired student t-test [emmer: $\mathrm{n}=18$; naked barley $\mathrm{n}=42$ ]; $\mathrm{p}$ : significance

The flavonoid catechin was the predominant phenol in the methanol-soluble fraction in naked barley, but it was completely missing in emmer (Tables 2 and 3). Some flavonoids reported in other studies as being present in barley besides catechin and proanthocyanidins (e.g. hesperidin, kaempferol, myricetin, naringenin, quercetin and rutin) $(20,21,30)$ could not be detected in the investigated naked barley cultivars. However, according to our knowledge, this is the first study documenting that artificial Fusarium infection led to a significant increase in the catechin content in the grains of about $4.5 \%$ in comparison to natural infection (Tables 2 and 3). We postulate, therefore, that in naked barley the biosynthesis of catechin can be induced as a reaction to $F$. graminearum and F. culmorum infection (Figure 2). We further postulate that catechin may represent a valuable marker to explain the lower susceptibility of barley to Fusarium spp. in comparison to emmer (Tables 1 and 2), because the degree of infection based on the Fusarium toxin content was much lower in naked barley than in emmer. However, the naked barley cultivars with the highest catechin content did not show the lowest susceptibility in all cases (data not shown). Therefore, we could conclude that catechin could be just one of the factors in naked barley characterizing its natural plant disease defence response as described in the literature (23). The induction of specific enzymes involved in the phenylpropanoid pathway after Fusarium infection may explain the observed change in catechin content (31). 
Table 3 Phenolic compounds in grains of each one emmer and naked barley cultivar after natural and artificial Fusarium infection as determined by different extraction procedures: Fraction 1: methanol soluble $(80 \% \mathrm{MeOH}+1 \%$ acetic acid); Fraction 2: acid-enzyme hydrolysable $\left(\mathrm{H}_{2} \mathrm{SO}_{4}\right.$ /enzyme)

\begin{tabular}{|c|c|c|c|c|c|}
\hline \multirow{3}{*}{ Fraction } & \multirow{3}{*}{ Phenol } & \multicolumn{4}{|c|}{ Phenol content ( $\mathrm{mg} \mathrm{kg}^{-1}$ ) } \\
\hline & & Emmer & v. Klein & Naked ba & y cv. ZFS \\
\hline & & $\begin{array}{c}\text { Natural } \\
\text { infection }\end{array}$ & $\begin{array}{l}\text { Artificial } \\
\text { infection }\end{array}$ & $\begin{array}{c}\text { Natural } \\
\text { infection }\end{array}$ & $\begin{array}{l}\text { Artificial } \\
\text { infection }\end{array}$ \\
\hline \multirow{4}{*}{1} & Catechin & n.d. & n.d. & 178.3 & 183.6 \\
\hline & Caffeic acid & 4.7 & 4.8 & 7.5 & 7.3 \\
\hline & Ferulic acid & 13.2 & 11.1 & 9.0 & 7.8 \\
\hline & $p$-Coumaric acid & n.d. & n.d. & n.d. & n.d. \\
\hline \multirow{4}{*}{2} & Catechin & n.d. & n.d. & n.d. & n.d. \\
\hline & Caffeic acid & 1.7 & 1.8 & 18.4 & 14.2 \\
\hline & Ferulic acid & 345.5 & 321.4 & 336.0 & 270.5 \\
\hline & $p$-Coumaric acid & 5.5 & 5.7 & 1.6 & n.d. \\
\hline \multirow{4}{*}{$\begin{array}{l}\text { Content in } \\
\text { fraction } 1+2\end{array}$} & Catechin & n.d. & n.d. & 178.3 & 183.6 \\
\hline & Caffeic acid & 6.4 & 6.5 & 25.9 & 21.5 \\
\hline & Ferulic acid & 345.5 & 332.6 & 345.1 & 278.3 \\
\hline & $p$-Coumaric acid & 5.5 & 5.7 & 1.6 & n.d. \\
\hline \multicolumn{2}{|c|}{ Total phenol content } & 357.4 & 344.8 & 550.9 & 483.4 \\
\hline
\end{tabular}

n.d. $=$ not detectable

In comparison, no catechin was found in the extracted cell-wall-bound fraction $\left(\mathrm{H}_{2} \mathrm{SO}_{4}\right.$ /enzyme hydrolyses) (Tables 2 and 3). Here, ferulic acid represented the predominant hydroxycinnamate derivate (13), followed by caffeic acid and $p$-coumaric acid. A statistically significant lower content of both ferulic and caffeic acid was found after artificial infection of naked barley in comparison to the naturally infected samples (Table 2). In emmer only ferulic acid was affected. In general, all the investigated cultivars of both emmer and naked barley responded with a reduction in their hydroxycinnamic acid contents (data not shown). These results are in agreement with those obtained for wheat cultivars also showing a reduced total phenol content (19). A 
reasonable tentative conclusion can thus be postulated that during Fusarium infection the synthesis of these substances may be reduced or disturbed. One of the reasons could be the inhibition of peptidyl transferase as shown in rats, representing an integral part of the $60 \mathrm{~S}$ ribosomal subunit, which is ubiquitous in eukaryotes, as well as the inhibition of DNA and RNA biosynthesis through the trichothecenes $(6,9)$. However, other investigations have shown that the organelle which is mostly affected by $F$. graminearum in the plant cell is the chloroplast, in which the synthesis of the aromatic amino acids, the precursors of phenolics, occurs (32). 


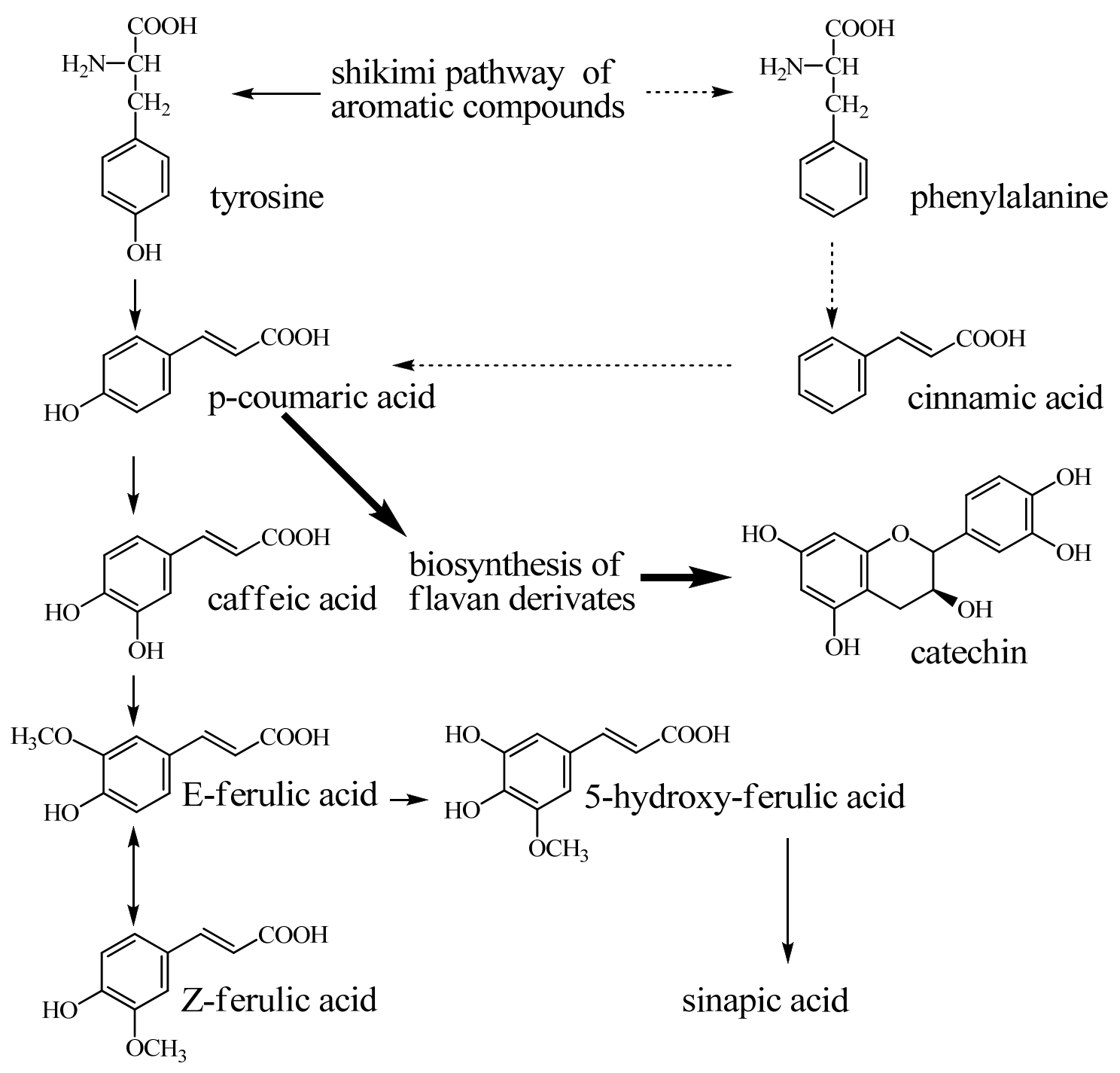

Figure 2 Supposed biosynthesis of caffeic, ferulic, and p-coumaric acid as well as catechin in the grains; preferred ways of synthesis in grain and those postulated after Fusarium infection in barley are shown with thick arrows; normal arrows show the steps of synthesis of ferulic acid, the main phenol in grain; dotted arrows showed synthesis of phenolic acids postulated by the literature

In the present study, an increase of ferulic and caffeic acid contents in the methanolsoluble fraction was not detected neither in artificial infected nor in naturally infected samples. Therefore, an enzymatic degradation, e.g. by fungal alpha-Narabinofuranosidase and feruloyl esterase (33), can be excluded. In naked barley, a reduced production of these substances was observed, probably due to the catechin synthesis being favoured (Figure 1). In grain, the derivates $p$-coumaric and caffeic acid 
are produced in 30 and 20 times lower concentrations than ferulic acid, respectively. These substances can be considered as being precursors of ferulic acid (34). It seems that the synthesis of $p$-coumaric and caffeic acid in the studied species is based on the amino acid tyrosine, because we did not find cinnamic acid as a precursor of $p$-coumaric acid. Therefore, the synthesis over the precursor phenylalanine and cinnamic acid may not have taken place in the grains of emmer and naked barley (Figure 1) (34).

The catechin concentration shown in Table 3 was determined by a different extraction procedure and we found its content doubled in comparison to the extraction without $\mathrm{H}_{2} \mathrm{SO}_{4}$ /enzyme hydrolysis after methanol extraction (Table 3). The reason for this doubling could have been the release of catechin out of precursors after hydrolysis and a more certain signal in the chromatogram (20). In the investigated naked barley cultivar ZFS, the soluble phenol proportion of the total phenol content rose up to $35 \%$, whereas the emmer cultivar Klein showed only 5\% soluble phenols. These differences in soluble phenol content between both the two cereals may confirm the higher susceptibility of emmer to Fusarium infection.

Total AX content. After artificial Fusarium infection, the investigated samples showed only marginal changes in their content of the AX sugars, xylose and arabinose, in comparison to the naturally infected samples (Table 4). There was no recognizable tendency that Fusarium infection changed the AX content (Table 4). The variations in emmer und naked barley were very low and so were not due to the presence of infection. Overall, AX was much less influenced by Fusarium infection than the ferulic acid content (Table 2). Ferulic acids acting as crosslinking molecules between AX chains showed a reduced content (Table 2). This reduction in crosslinking can diminish the function of $\mathrm{AX}$ as a barrier against bio-degradability by micro-organisms and reflects a reduced cell wall rigidity (35). Also crosslinks with other cell wall components bound to $\mathrm{AX}$, such as lignin (ether bound), protein, cellulose or other polysaccharides (ester bound) may also be influenced by the Fusarium-induced ferulic acid reduction $(15,17,18,36)$. This process thus illustrates how Fusarium infection may succeed. However, these alterations in grain cell wall structure and crosslinking may also contribute to a lower and modified baking quality (37) as well as provoking a fragmentation of $\mathrm{AX}$. 
Table 4 Content of total arabinoxylan monosaccharides in grains of each one emmer and naked barley cultivar after natural and artificial Fusarium infection

\begin{tabular}{|c|c|c|c|c|}
\hline \multirow{3}{*}{ Monosaccharides } & \multicolumn{4}{|c|}{ Monosaccharide content $\left(\mathrm{g} \mathrm{kg}^{-1}\right)$} \\
\hline & \multicolumn{2}{|c|}{ Emmer: cv. Klein } & \multicolumn{2}{|c|}{ Naked barley: cv. ZFS } \\
\hline & Natural infection & Artificial infection & Natural infection & Artificial infection \\
\hline Xylose & \pm 0.3 & $23.9 \pm 0.4$ & \pm 0.3 & \pm 0.5 \\
\hline Arabinose & \pm 0.2 & $20.2 \pm 0.2$ & \pm 0.1 & \pm 0.2 \\
\hline
\end{tabular}

data are presented as mean value \pm standard deviation

Looking at the differences in the content of arabinose, xylose and AX between the two cereals, a lower content of AX in emmer of about $20 \%$ in comparison to naked barley was found. The literature data showed a wide range for $\mathrm{AX}$ in the different cereal species from 21 to $171 \mathrm{~g} \mathrm{~kg}^{-1}$, for arabinose from 12 to $55 \mathrm{~g} \mathrm{~kg}^{-1}$, and for xylose from 7 to $148 \mathrm{~g} \mathrm{~kg}^{-1}$ (38). The $\mathrm{AX}$ sugars in our investigation were not reduced in equal quantities: the xylose content in emmer was about $10 \%$ lower than in naked barley and the arabinose concentration was reduced to about $30 \%$. The lower arabinose content in emmer in comparison to naked barley emphasizes a reduced crosslinking potential in the cell walls of the former species. This result, thus, provides a further reason for the lower susceptibility of naked barely to Fusarium infection, since a more complex network in the cell wall leads to higher cell wall rigidity and a reduced enzymatic degradation by Fusarium.

The higher caffeic acid concentration in the grains of naked barley compared to emmer may also be a further relevant factor in reducing its susceptibility to Fusarium besides its high B-glucan content of about 5\% (39), the latter being 10-15\% higher than in emmer. The participation of these compounds in a stronger interaction to other cell wall compounds may contribute to the barley's resistance against the mycelia growing from the fungus and thus reduce the degree of infection.

The presented results document that phenolic acid contents in the grains of both emmer and naked barley were influenced by Fusarium infection, leading to a significant reduction in the total content of ferulic acid as the predominant phenol in the grains. The total AX did not change as a result of the Fusarium infection. However, comparing the two types of cereals, we found higher AX contents in naked barly than in emmer and 
more arabinose providing a possible site for a phenol involved crosslinking. In addition, naked barley grains contained the flavonoid catechin which was significantly higher concentrated after artificial Fusarium infection in comparison to naturally infected samples. Catechin is lacking in emmer and this might be one of the reasons for the higher susceptibility of this species to the fungus. Further investigations are necessary to clarify the putative degradation of $\mathrm{AX}$ and to show the influence of fungal enzymes on structures containing AX. Furthermore, studies with coloured barley cultivars, such as blue purple or black ones, should be performed to clarify the influence of flavonoids, proanthocyanidins and anthocyans on the extend of Fusarium infection. Additionally, it is important to clarify and review the postulated and preferred mechanism of the phenol synthesis in infected grains described here, and to elucidate the factors determining this modulation.

\section{Abbreveations used}

AX, arabinoxylan; FHB, Fusarium head blight; DON, deoxynivalenol; 3-Ac-DON, 3acetyl-deoxynivalenol; LC-MS/MS, liquid chromatography with coupled mass spectrometry; p, significance factor; RP-HPLC, reverse phase high pressure liquid chromatography, GC-MS/MS gas chromatography with coupled mass spectrometry

\section{Acknowledgements}

This work is a part of the FAEN Joint Project 3 "Quality-related plant production under modified basic conditions: mycotoxins in the context of production, quality and processing", financed by the Ministry of Science and Culture of Lower Saxony, Germany. Special thanks are given to the growers who provided the seeds for this research trial: Dr. Karl-Josef Müller, Getreidezüchtungsforschung Darzau; Eckard Irion, Verein für Pflanzenzucht Hof Grub e.V.; Claus Einfeldt, Saatzucht Ackermann; and Hans-Werner Klein, UGB Gesundheitsförderung; as well as for the toxin analysis by the group of Prof. Petr Karlovsky and Sasithorn Limsuwan, Molecular Phytopathology and Mycotoxin Research, Department of Crop Sciences, University of Göttingen, 37075 Göttingen, Germany. 


\section{References}

1. Bottalico, A.; Perrone, G., Toxigenic Fusarium species and mycotoxins associated with head blight in small-grain cereals in Europe. Eur. J. Plant Pathol. 2002, 108, (7), 611-624.

2. Parry, D. W.; Jenkinson, P.; McLeod, L., FUSARIUM EAR BLIGHT (SCAB) IN SMALL-GRAIN CEREALS - A REVIEW. Plant Pathol. 1995, 44, (2), 207-238.

3. Ramirez, M. L.; Reynoso, M. M.; Farnochi, M. C.; Chulze, S., Vegetative compatibility and mycotoxin chemotypes among Fusarium graminearum (Gibberella zeae) isolates from wheat in Argentina. Eur. J. Plant Pathol. 2006, 115, (2), 139-148.

4. Yang, L.; van der Lee, T.; Yang, X.; Yu, D.; Waalwijk, C., Fusarium populations on Chinese barley show a dramatic gradient in mycotoxin profiles. Phytopathol. 2008, 98, (6), 71927.

5. $\quad$ Buerstmayr, H.; Stierschneider, M.; Steiner, B.; Lemmens, M.; Griesser, M.; Nevo, E.; Fahima, T., Variation for resistance to head blight caused by Fusarium graminearum in wild emmer (Triticum dicoccoides) originating from Israel. Euphytica 2003, 130, (1), 17-23.

6. Eriksen, G. S.; Pettersson, H., Toxicological evaluation of trichothecenes in animal feed. Anim. Feed Sci. Technol. 2004, 114, (1-4), 205-239.

7. Thuvander, A.; Wikman, C.; Gadhasson, I., In vitro exposure of human lymphocytes to trichothecenes: individual variation in sensitivity and effects of combined exposure on lymphocyte function. Food Chem. Toxicol. 1999, 37, (6), 639-48.

8. Tsuda, S.; Kosaka, Y.; Murakami, M.; Matsuo, H.; Matsusaka, N.; Taniguchi, K.; Sasaki, Y. F., Detection of nivalenol genotoxicity in cultured cells and multiple mouse organs by the alkaline single-cell gel electrophoresis assay. Mutat. Res. 1998, 415, (3), 191-200.

9. Yabe, T.; Hashimoto, H.; Sekijima, M.; Degawa, M.; Hashimoto, Y.; Tashiro, F.; Ueno, Y., Effects of nivalenol on hepatic drug-metabolizing activity in rats. Food Chem. Toxicol. 1993, 31, (8), 573-81.

10. Siranidou, E.; Kang, Z.; Buchenauer, H., Studies on symptom development, phenolic compounds and morphological defence responses in wheat cultivars differing in resistance to Fusarium head blight. J. Phytopathol. 2002, 150, (4-5), 200-208.

11. Hernanz, D.; Nunez, V.; Sancho, A. I.; Faulds, C. B.; Williamson, G.; Bartolome, B.; Gomez-Cordoves, C., Hydroxycinnamic acids and ferulic acid dehydrodimers in barley and processed barley. J. Agric. Food Chem. 2001, 49, (10), 4884-8.

12. Santiago, R.; Reid, L. M.; Arnason, J. T.; Zhu, X.; Martinez, N.; Malvar, R. A., Phenolics in maize genotypes differing in susceptibility to Gibberella stalk rot (Fusarium graminearum Schwabe). J. Agric. Food Chem. 2007, 55, (13), 5186-93.

13. Zhou, K.; Hao, J.; Griffey, C.; Chung, H.; O'Keefe, S. F.; Chen, J.; Hogan, S., Antioxidant properties of Fusarium head blight-resistant and -susceptible soft red winter wheat grains grown in Virginia. J. Agric. Food Chem. 2007, 55, (9), 3729-36.

14. Allerdings, E.; Ralph, J.; Schatz, P. F.; Gniechwitz, D.; Steinhart, H.; Bunzel, M., Isolation and structural identification of diarabinosyl 8-O-4-dehydrodiferulate from maize bran insoluble fibre. Phytochemistry 2005, 66, (1), 113-24.

15. Bunzel, M.; Ralph, J.; Marita, J. M.; Hatfield, R. D.; Steinhart, H., Diferulates as structural components in soluble and insoluble cereal dietary fibre. J. Sci. Food Agric. 2001, 81, (7), 653-660.

16. Izydorczyk, M. S.; Biliaderis, C. G., Cereal arabinoxylans: Advances in structure and physicochemical properties. Carbohydr. Polm. 1995, 28, (1), 33-48.

17. Philippe, S.; Tranquet, O.; Utille, J. P.; Saulnier, L.; Guillon, F., Investigation of ferulate deposition in endosperm cell walls of mature and developing wheat grains by using a polyclonal antibody. Planta 2007, 225, (5), 1287-99. 
18. Pitkanen, L.; Tuomainen, P.; Virkki, L.; Aseyev, V.; Tenkanen, M., Structural comparison of arabinoxylans from two barley side-stream fractions. J. Agric. Food Chem. 2008, 56, (13), 5069-77.

19. McKeehen, J. D.; Busch, R. H.; Fulcher, R. G., Evaluation of wheat (Triticum aestivum L.) phenolic acids during grain development and their contribution to Fusarium resistance. $J$ Agric. Food Chem. 1999, 47, (4), 1476-1482.

20. Quinde-Axtell, Z.; Baik, B. K., Phenolic compounds of barley grain and their implication in food product discoloration. J. Agric. Food Chem. 2006, 54, (26), 9978-84.

21. Kim, M. J.; Hyun, J. N.; Kim, J. A.; Park, J. C.; Kim, M. Y.; Kim, J. G.; Lee, S. J.; Chun, S. C.; Chung, I. M., Relationship between phenolic compounds, anthocyanins content and antioxidant activity in colored barley germplasm. J. Agric. Food Chem. 2007, 55, (12), 4802-9.

22. Zagoskina, N. V.; Olenichenko, N. A.; Iun'vei, C.; Zhivukhina, E. A., [Formation of phenol compounds in various cultivars of wheat (Triticum aestivum L.)]. Prikl. Biokhim. Mikrobiol. 2005, 41, (1), 113-6.

23. Dixon, R. A., Natural products and plant disease resistance. Nature 2001, 411, (6839), 843-7.

24. Santos-Buelga, C.; Scalbert, A., Proanthocyanidins and tannin-like compounds - nature, occurrence, dietary intake and effects on nutrition and health. J. Sci. Food Agric. 2000, 80, (7), 1094-1117.

25. Adejumo, T. O.; Hettwer, U.; Karlovsky, P., Occurrence of Fusarium species and trichothecenes in Nigerian maize. Int. J. Food Microbiol. 2007, 116, (3), 350-357.

26. Yu, J.; Vasanthan, T.; Temelli, F., Analysis of phenolic acids in barley by highperformance liquid chromatography. J. Agric. Food Chem. 2001, 49, (9), 4352-8.

27. Hollmann, J.; Lindhauer, M. G., Pilot-scale isolation of glucuronoarabinoxylans from wheat bran. Carbohydr. Polm. 2005, 59, (2), 225-230.

28. Oliver, R. E.; Stack, R. W.; Miller, J. D.; Cai, X., Reaction of wild emmer wheat accessions to Fusarium head blight. Crop Sci. 2007, 47, (2), 893-899.

29. Mattila, P.; Pihlava, J. M.; Hellstrom, J., Contents of phenolic acids, alkyl- and alkenylresorcinols, and avenanthramides in commercial grain products. J. Agric. Food Chem. 2005, 53, (21), 8290-5.

30. Gu, L.; Kelm, M. A.; Hammerstone, J. F.; Beecher, G.; Holden, J.; Haytowitz, D.; Prior, R. L., Screening of foods containing proanthocyanidins and their structural characterization using LC-MS/MS and thiolytic degradation. J. Agric. Food Chem. 2003, 51, (25), 7513-21.

31. Boddu, J.; Cho, S.; Kruger, W. M.; Muehlbauer, G. J., Transcriptome analysis of the barley-Fusarium graminearum interaction. Mol. Plant-Microbe Interact. 2006, 19, (4), 407-17.

32. Zhou, W.; Eudes, F.; Laroche, A., Identification of differentially regulated proteins in response to a compatible interaction between the pathogen Fusarium graminearum and its host, Triticum aestivum. Proteomics 2006, 6, (16), 4599-609.

33. Wanjiru, W. M.; Kang, Z. S.; Buchenauer, H., Importance of cell wall degrading enzymes produced by Fusarium graminearum during infection of wheat heads. Eur. J. Plant Pathol. 2002, 108, (8), 803-810.

34. Schoch, G.; Goepfert, S.; Morant, M.; Hehn, A.; Meyer, D.; Ullmann, P.; WerckReichhart, D., CYP98A3 from Arabidopsis thaliana is a 3'-hydroxylase of phenolic esters, a missing link in the phenylpropanoid pathway. J. Biol. Chem. 2001, 276, (39), 36566-74.

35. Ishii, T., Structure and functions of feruloylated polysaccharides. Plant Sci. 1997, 127, (2), 111-127.

36. Renger, A.; Steinhart, H., Ferulic acid dehydrodimers as structural elements in cereal dietary fibre. Eur. Food Res. Technol. 2000, 211, (6), 422-428. 
37. Izydorczyk, M.; Biliaderis, C. G.; Bushuk, W., Comparison of the Structure and Composition of Water-Soluble Pentosans from Different Wheat-Varieties. Cereal Chem. 1991, $68,(2), 139-144$.

38. Blakeney, A. B.; Flinn, P. C., Determination of non-starch polysaccharides in cereal grains with near-infared reflectance spectroscopy. Mol. Nutr. Food Res. 2005, 49, (6), 546-50.

39. Bhatty, R. S., The potential of hull-less barley. Ceareal Chemistry 1999, 76, (5), 589599. 



\title{
5.3 The influence of Fusarium infection and growing location on the quantitative protein composition of (Part I) emmer (Triticum dicoccum)
}

Kai Eggert, Herbert Wieser, Elke Pawelzik, European Food Research and Technology (2010), 230: 837-847

\begin{abstract}
The effect of the fungal infection by Fusarium graminearum and Fusarium culmorum of emmer and wheat cultivars on their total protein content and the protein fractions albumins + globulins, gliadins and glutenins and their different protein types was investigated. Additionally, the influence of two different locations on the quantitative protein composition was evaluated. The results showed that Fusarium infection changed the content of gliadins and glutenins in emmer and wheat. The wheat glutenin fractions and types were found to be more strongly affected by the Fusarium spp. infection than the glutenin fractions and types in emmer cultivars in spite of the wheat's lower degree of infection. The nitrogen supply at the two locations was associated with an increase in the gliadin content in emmer and an increase in the glutenin content in emmer and wheat. Nitrogen availability, a factor which promotes gene expression, resulted here in a species-specific effect on the gliadin/glutenin ratio.
\end{abstract}

Keywords: emmer; Fusarium; Fusarium protein units (FPU); ELISA; deoxynivalenol

\section{Introduction}

Fusarium graminearum and Fusarium culmorum infection of cereals grains (such as wheat, barley and emmer) leads to pathogenic effects on the plant and spike. These can result in dramatic yield and quality losses $[1,2]$. Fusarium head blight (FHB) is the visible effect of this fungal infection and is a problem known throughout the world [1, 3, 4]. These two Fusarium species are producers of trichothecene mycotoxins like deoxynivalenol, 3- and 15-acetyldeoxynivalenol (3-Ac-DON and 15-Ac-DON, resp.; major DON precursors) and others [1]. The trichothecene mycotoxins are potential inhibitors of protein biosynthesis. In mammals, they lead to unspecific effects in the intestine causing diarrhoea, vomiting, a reduced food intake and a raised bleeding tendency of the intestines. Their more specific effects include reduced leukocyte content connected with a loss of the immune function and an increase in free radicals in the liver $[5-8]$. 
Emmer (Triticum dicoccum) cultivars are normally grown in organic farming systems. At the moment, little knowledge exists about the influence of Fusarium infection on the protein fractions in this species. The total protein content is documented for emmer at around $12-13 \%$ of dry mass [9]. The influence of Fusarium infection on grain protein composition has been mainly investigated in wheat cultivars. The results from these investigations have suggested that depending on infection degree, no impact on total protein content could be observed or just moderately increased concentrations of total protein could be documented $[10,11]$. However, an influence on protein fractions, such as an increase in gliadin and a reduction in glutenin content, has also been recorded. A change in the synthesis behaviour at different maturation stages has been postulated as an explanation for this observation [11]. Studies focusing on the synthesis of cereal seed storage proteins did not show any alterations in the synthesis stages during grain maturation; only a belated polymerization of glutenins was noted [12]. An influence of Fusarium infection on LMW glutenin degradation has been shown in a study which focused on suboptimal storage conditions [13].

The total protein content in wheat cultivars is also increased by increasing the nitrogen supply. The sizes of the gliadin and glutenin fractions are also changed. However, nitrogen has apparently no influence on the albumin and globulin fractions $[14,15]$. It is not known how emmer reacts to increasing the supply of nitrogen.

The presented study focuses on the influence of artificial Fusarium infection on the Osborne protein fractions and single protein types in emmer in comparison to naturally infected samples. Our investigations were done on harvested grains to determine the conditions in fully developed grains. Additionally, the effect of two different locations on the content of total protein and protein fractions and types was also monitored. Finally, the question as to what modifications of protein composition and protein synthesis occur in connection to nitrogen availability and exposition to Fusarium infection was addressed. A wheat cultivar was used for comparison.

\section{Material and Methods}

\section{Experimental design and sample preparation}

Three emmer cultivars (Linie 9-102, Far-108+hein-101, Klein) and for comparison, one summer wheat (Amaretto) cultivar grown in two field trials at Reinshof [16] and Sattenhausen (SH) in the centre of Germany near Göttingen were randomized with eight replications. In each block, the second row was artificially inoculated with a mixed $F$. 
culmorum and F. graminearum spore suspension $\left(50 \mathrm{ml} / \mathrm{m}^{2} ; 1 \times 10^{5}\right.$ spores $\left./ \mathrm{ml}\right)$ three times during flowering. Three DON-producing strains of F. culmorum (FC34, FC35, FC36) and F. graminearum (FG142; FG143; FG144) were used for conidiospore production. Only 3-Ac-DON could be detected in these strains, not 15-Ac-DON. After harvest, the grain without inoculation (natural infection) and with inoculation (artificial infection) from the plots (four replications each) from each field trial were mixed. Whole grain flour was obtained by milling (Retsch ZM 100, Haan, Germany) at a particle size of $0.5 \mathrm{~mm}$.

The location conditions at Reinshof [16] are $152 \mathrm{~m}$ above sea level, wind sheltered and dale area near a river border. The $\mathrm{N}_{\text {min }}$ content was $145 \mathrm{~kg} / \mathrm{ha}$ recorded in $90 \mathrm{~cm}$ depth dry soil. At Sattenhausen (SH), the conditions are $260 \mathrm{~m}$ above sea level, hilly and windy. The $\mathrm{N}_{\min }$ content was $95 \mathrm{~kg} / \mathrm{ha}$ in $90 \mathrm{~cm}$ dry soil with an additional fertilization of $40 \mathrm{~kg} \mathrm{~N} / \mathrm{ha}$ two months after sowing.

\section{Quantitative LC-MS/MS of Fusarium mycotoxin DON and 3-Ac-DON}

Whole grain flour $(5 \mathrm{~g})$ was extracted with $40 \mathrm{ml}$ of an acetonitrile-water mixture (80:20) over night on a reciprocal shaker. The extracts were centrifuged for $12 \mathrm{~min}$ at $5,000 \times \mathrm{g}$ and $4 \mathrm{ml}$ of the supernatant were used for solid-phase extraction (Bond-Elut Mycotoxin, Varian GmbH, Darmstadt, Germany) according to the manufacturer's instructions. Two millilitres of the cleaned extract were evaporated to dryness under vacuum, redissolved in $200 \mu \mathrm{l}$ of methanol-water (50:50) containing $0.2 \mathrm{mmol}$ ammonium acetate and $10 \mu \mathrm{l}$ of the solution were injected onto a C18 column $(100 \times 2$ $\mathrm{mm}, 3 \mu \mathrm{m}$ particle size) filled with polar modified material (Polaris Ether, Varian GmbH, Darmstadt, Germany). The analytes were eluted with a methanol-water gradient ( $15 \%$ to $70 \%$ over $20 \mathrm{~min}$ ) containing $0.2 \mathrm{mmol}$ ammonium acetate at a flow rate of 0.2 $\mathrm{ml} / \mathrm{min}$. DON and 3-Ac-DON were detected by tandem mass spectrometry as described by Adejumo et al. [17].

\section{Quantitative nitrogen analysis}

The nitrogen content was quantitatively measured with a $\mathrm{C} / \mathrm{N}$-analyser (Vario MAX CN Elementar Analysesysteme GmbH, Hanau, Germany). A 100-mg dry sample for each emmer and wheat cultivar was analysed for its $\mathrm{N}$ content. This was converted to protein using the factor 5.7 for both the emmer and wheat (ICC No. 105/2).

Quantification of Fusarium Protein Units 
Biotin/Avidin ELISA, a double-antibody sandwich with rabbit-anti-fungal antibody was performed to detect the soluble Fusarium Protein Units (FPU) in $\mathrm{mg} / \mathrm{kg}$ using 96-well convex-bottomed plates (Immuno Plate Maxisorb, Nunc International, Denmark) and a photometer (Spectra II, SLT Laborinstruments, Austria). The FPU were extracted from the milled grain with 20 times of buffer quantity $(0.01 \mathrm{~mol} / 1$ phosphate buffer $+0.05 \%$ [v/v] Tween 20 [PBST] and 1\% polyvinylpolypyrrolidone [PVP] $\mathrm{pH}$ 7.2) by shaking for $12 \mathrm{~h}$ at $4^{\circ} \mathrm{C}$. The extract was centrifuged $(12,000 \mathrm{~g} / 4 \mathrm{~min})$ and the supernatant was used for ELISA.

To prepare the micro-wells, $100 \mu \mathrm{IgG}$ in $0.05 \mathrm{M}$ carbonate buffer/loading buffer $\left[\mathrm{Na}_{2} \mathrm{CO}_{3} / \mathrm{NaHCO}_{3}\right] \mathrm{pH} 9.6$ was placed in each cavity and the antibodies were immobilized on the surface during an incubation time of $12 \mathrm{~h}$ at $4^{\circ} \mathrm{C}$. The wells were then washed 3 times for 3 min with $100 \mu$ washing buffer (1/1 PBST/dest. $\left.\mathrm{H}_{2} \mathrm{O} v / \mathrm{v}\right)$, and dried by beating the wells gently on a paper towel. To block non-specific binding, $200 \mu 1 \%(\mathrm{wt} / \mathrm{v})$ defatted milk powder in loading buffer was added and incubated for 1 $\mathrm{h}$ at $37^{\circ} \mathrm{C}$. The wells were washed again. Following this, $100 \mu \mathrm{l}$ of sample extract was added and incubated for $12 \mathrm{~h}$ at $4^{\circ} \mathrm{C}$. The wells were washed again. In the next step 100 $\mu 1$ biotinylated antibodies in binding buffer $(0.2 \%$ [wt/v] BSA + PBST, $\mathrm{pH} 7.2)$ were added and incubated for $12 \mathrm{~h}$ at $4^{\circ} \mathrm{C}$. The wells were then washed as described in the steps before. Subsequently, $100 \mu 1$ streptavidin alkaline phosphatase (dissolved 1:10000 (v/v) in binding-buffer) was added to each well and incubated for $1 \mathrm{~h}$ at room temperature, following which, the washing step was repeated. Finally, $100 \mu$ l buffer (1 $\mathrm{mg} / \mathrm{ml} \mathrm{p}$-nitrophenyl phosphate in diethanolamine buffer, $\mathrm{pH} 9.8$ ) was added and incubated at room temperature for $2 \mathrm{~h}$. The absorption was then measured at $450 \mathrm{~nm}$ (with reference at $592 \mathrm{~nm}$ ). For the external standard, cleaned soluble Fusarium protein (F. culmorum/F. graminearum) was used to create a standard row as FPU in $\mathrm{mg} \mathrm{g}^{-1}$ sample, with the protein content of the standard being based on a Bradford assay [18]. For analysis of the protein content of the Fusarium standard, cleaned F. graminearum was used and the soluble and insoluble fractions were measured with $\mathrm{C} / \mathrm{N}$ analyser.

Quantitative protein analysis with RP-HPLC

Protein extraction from $100 \mathrm{mg}$ flour samples was realised stepwise. In the first step, 1 $\mathrm{ml}$ extraction with solution $\mathrm{A}\left[\mathrm{HKNaPO}_{4}: 97\right.$ parts $\mathrm{Na}_{2} \mathrm{HPO}_{4}(0.067 \mathrm{~mol} / \mathrm{l})+(0.4 \mathrm{~mol} / \mathrm{l})$ $\mathrm{NaCl}$ and 3 parts $\mathrm{KH}_{2} \mathrm{HPO}_{4}(0.067 \mathrm{~mol} / \mathrm{l})+(0.4 \mathrm{~mol} / \mathrm{l}) \mathrm{NaCl}$; $\left.\left.\mathrm{pH} 7.6\right)\right]$ by vortexing for $2 \mathrm{~min}$ and shaking at room temperature for $10 \mathrm{~min}$ for the albumin/globulin fractions 
was repeated twice. The samples were centrifuged for $20 \mathrm{~min}$ at $6,000 \mathrm{~g}$ and the supernatants were combined and filled up to $2 \mathrm{ml}$. The pellet was then extracted three times with $0.5 \mathrm{ml}$ extraction solution B [60\% ethanol (v/v)], vortexed for $2 \mathrm{~min}$ and exposed to $10 \mathrm{~min}$ of shaking at room temperature. The samples were subsequently centrifuged for $20 \mathrm{~min}$ at $6,000 \mathrm{~g}$ and the gliadin-containing supernatants were combined and filled up to $2 \mathrm{ml}$. In the third step, the remaining pellet was extracted two times with $1 \mathrm{ml}$ extraction solution C [50\% 1-propanol (v/v)/ $2 \mathrm{~mol} / \mathrm{l}$ urea, $0.05 \mathrm{~mol} / 1$ Tris/ $\mathrm{HCl}(\mathrm{pH} 7.5)+1 \%$ dithioerythritol (DTE)] under $\mathrm{N}_{2}$, with 2 min vortexing and 30 min shaking at $60^{\circ} \mathrm{C}$. The samples were centrifuged for $20 \mathrm{~min}$ at $6,000 \mathrm{~g}$ and these glutenin-containing supernatants were combined and filled up to $2 \mathrm{ml}$. All the extracts were filtered with a $0.45-\mu \mathrm{m}$ filter: FP $30 / 0.45 \mathrm{CA}$ Whatman (schleicher + schuell, Germany) before HPLC injection.

For the RP-HPLC, a Nucleosil 300-5 C8 250 x 4.6 silica column (Macherey-Nagel, Dueren, Germany) was used. As mobile phases, $\mathrm{A}=0.1 \%$ TFA in $\mathrm{H}_{2} \mathrm{O}(\mathrm{v} / \mathrm{v})$ and $\mathrm{B}=$ $0.1 \%$ TFA in acetonitrile (v/v) were applied. The flow rate was $1 \mathrm{ml} / \mathrm{min}$ with the column temperature maintained at $50^{\circ} \mathrm{C}$. For the detection of albumins/globulins, $150 \mu 1$ of sample solution was injected and separated by using the following gradient: $0 \mathrm{~min}$, $20 \% \mathrm{~B} ; 20 \mathrm{~min}, 60 \% \mathrm{~B}$; whereas for the gliadins and glutenins, $50 \mu 1$ and $100 \mu 1$ were injected, respectively and the separation was performed by applying the following gradient: $0 \mathrm{~min}, 24 \% \mathrm{~B} ; 50 \mathrm{~min}, 56 \% \mathrm{~B}$ [19]. For the quantification of the protein fractions the external PWG (Prolamin Working Group) gliadin standard was used [20] (Figure 1). 


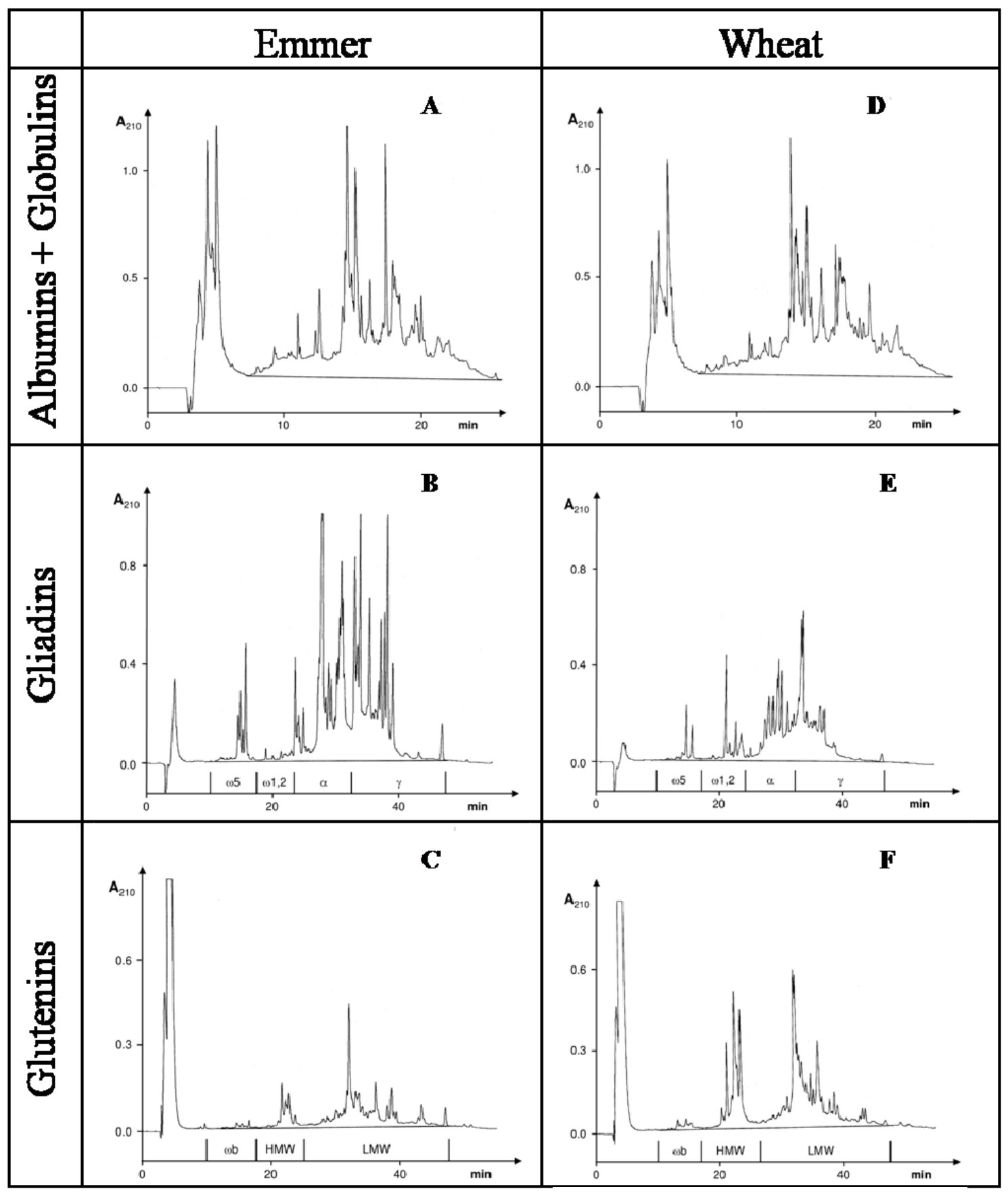

Figure 1 RP-HPLC of protein fractions in emmer [Linie 9-102] and wheat [Amaretto]: A/D: 1. albumins/globulins total; B/E: 2. $\omega 5$-gliadins; 3. $\omega 1$,2-gliadins; 4. $\alpha$-gliadins; 5.

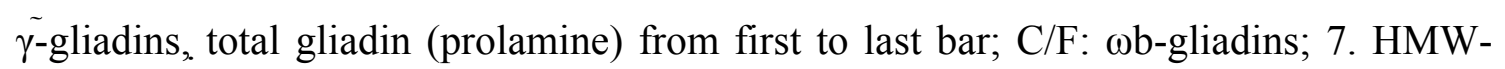
GS; 8: LMW-GS; total glutenin (glutelins) from first to last bar

Statistical analyses were performed using Microsoft Excel 2003 for mean value, standard deviation and significance $(p)$. 


\section{Results and Discussion}

The influence of Fusarium infection on the quantitative protein composition of emmer The detected fungal content expressed as Fusarium toxin (DON and 3-Ac-DON) in the three emmer cultivars and the wheat cultivar showed a significant increase in all the investigated parameters after artificial infection in comparison to the naturally infected cultivars (Tables 1a-f). This confirms that the two cereals and their tested cultivars were susceptible to Fusarium spp. [2, 4, 21]. The total protein $(\mathrm{N} x 5.7)$ and the extractable protein content of the two cereals and their cultivars did not change significantly with respect to the Fusarium infection (Table 1f). These results are in accordance with an earlier study in which no impact on the total protein content in F. culmorum-infected samples was also found [11]. In contrast, however, older results on F. graminearum found a moderate increase in the total protein content depending on the degree of infection [10]. 
Table 1a Protein concentration $\left(\mathrm{g} \mathrm{kg}^{-1}\right)$ in naturally and artificially Fusarium infected grain from the emmer cultivar Linie 9-102 and the relative variance between natural and artificial infection (\%) at the locations Sattenhausen and Reinshof as well as the DON and 3-Ac-DON concentration of the naturally and artificially infected grain

\begin{tabular}{|c|c|c|c|c|c|c|c|c|c|c|c|}
\hline \multirow{3}{*}{$\begin{array}{l}\text { Protein Fractions } \\
\qquad\left(\mathrm{g} \mathrm{kg}^{-1}\right)\end{array}$} & \multirow{3}{*}{$\begin{array}{l}\text { Type } \\
\text { Total }\end{array}$} & \multicolumn{5}{|c|}{ Sattenhausen } & \multicolumn{5}{|c|}{ Reinshof } \\
\hline & & \multicolumn{2}{|c|}{$\begin{array}{c}\text { Natural } \\
\text { infection }\end{array}$} & \multicolumn{2}{|c|}{$\begin{array}{l}\text { Artificial } \\
\text { infection }\end{array}$} & \multirow{2}{*}{$\begin{array}{c}\% \text { Variance } \\
\text { natural to } \\
\text { artificial } \\
\text { infection }\end{array}$} & \multicolumn{2}{|c|}{$\begin{array}{l}\text { Natural } \\
\text { infection }\end{array}$} & \multicolumn{2}{|c|}{$\begin{array}{l}\text { Artificial } \\
\text { infection }\end{array}$} & \multirow{2}{*}{$\begin{array}{c}\% \text { Variance } \\
\text { natural to } \\
\text { artificial } \\
\text { infection }\end{array}$} \\
\hline & & 21.6 & \pm 0.4 & 21.4 & \pm 0.0 & & 22.3 & \pm 1.1 & 22.0 & \pm 1.0 & \\
\hline \multirow{5}{*}{ Gliadins } & Total & 90.3 & \pm 0.9 & 89.5 & \pm 0.6 & -1 & 118.4 & \pm 0.3 & 119.8 & \pm 1.9 & 1 \\
\hline & $\omega 5$ & 4.0 & \pm 0.1 & 3.8 & \pm 0.1 & -5 & 7.5 & \pm 0.1 & 7.3 & \pm 0.2 & -2 \\
\hline & $\omega 1,2$ & 0.9 & \pm 0.1 & 0.7 & \pm 0.1 & -21 & 1.4 & \pm 0.1 & 1.2 & \pm 0.2 & -17 \\
\hline & $\alpha$ & 39.1 & \pm 0.3 & 38.5 & \pm 0.6 & -1 & 54.7 & \pm 0.6 & 55.3 & \pm 1.3 & 1 \\
\hline & $\gamma$ & 46.3 & \pm 0.4 & 46.5 & \pm 0.8 & 0 & 54.8 & \pm 0.6 & 55.9 & \pm 0.2 & 2 \\
\hline \multirow{4}{*}{ Glutenins } & Total & 13.3 & \pm 0.1 & 11.2 & \pm 0.5 & -16 & 15.7 & \pm 0.1 & 13.9 & \pm 0.0 & -12 \\
\hline & $\omega b$ & 0.3 & \pm 0.0 & 0.3 & \pm 0.1 & 0 & 0.6 & \pm 0.0 & 0.4 & \pm 0.1 & -33 \\
\hline & HMW-GS & 1.7 & \pm 0.2 & 1.4 & \pm 0.1 & -19 & 2.7 & \pm 0.1 & 2.2 & \pm 0.2 & -18 \\
\hline & LMW-GS & 11.3 & \pm 0.3 & 9.5 & \pm 0.6 & -15 & 12.4 & \pm 0.1 & 11.3 & \pm 0.2 & -9 \\
\hline Gluten & Total & 103.6 & \pm 1.0 & 100.7 & \pm 0.1 & -3 & 134.1 & \pm 0.4 & 133.7 & \pm 2.3 & 0 \\
\hline Gliadin/Glutenin & Ratio & \multicolumn{2}{|c|}{6.8} & \multicolumn{2}{|c|}{8.0} & - & \multicolumn{2}{|c|}{7.5} & \multicolumn{2}{|c|}{8.6} & - \\
\hline Extract Proteins & Total & 125.2 & \pm 1.4 & 122.1 & \pm 0.1 & -2 & 156.4 & \pm 1.5 & 155.7 & \pm 3.3 & 0 \\
\hline \multirow[t]{2}{*}{ Protein Content } & Total & \multicolumn{2}{|c|}{159.8} & \multicolumn{2}{|c|}{152.2} & -5 & \multicolumn{2}{|c|}{205.8} & \multicolumn{2}{|c|}{208.7} & 1 \\
\hline & DON & 0.4 & \pm 0.0 & 2.8 & \pm 0.9 & - & 1.7 & \pm 0.3 & 10.3 & \pm 0.7 & - \\
\hline \multirow[t]{2}{*}{ Toxin $\left(\mathrm{mg} \mathrm{kg}^{-1}\right)$} & 3-Ac-DON & 0.0 & \pm 0.0 & 0.1 & \pm 0.0 & - & 0.1 & \pm 0.0 & 0.6 & \pm 0.0 & - \\
\hline & Total & \multicolumn{2}{|c|}{0.4} & \multicolumn{2}{|c|}{2.9} & - & \multicolumn{2}{|c|}{1.8} & \multicolumn{2}{|c|}{10.9} & - \\
\hline
\end{tabular}


Table 1b Protein concentration $\left(\mathrm{g} \mathrm{kg}^{-1}\right)$ in naturally and artificially Fusarium infected grain from the emmer cultivar Far-108 + Hein-101 and the relative variance between natural and artificial infection (\%) at the locations Sattenhausen and Reinshof as well as the DON and 3-Ac-DON concentration of the naturally and artificially infected grain

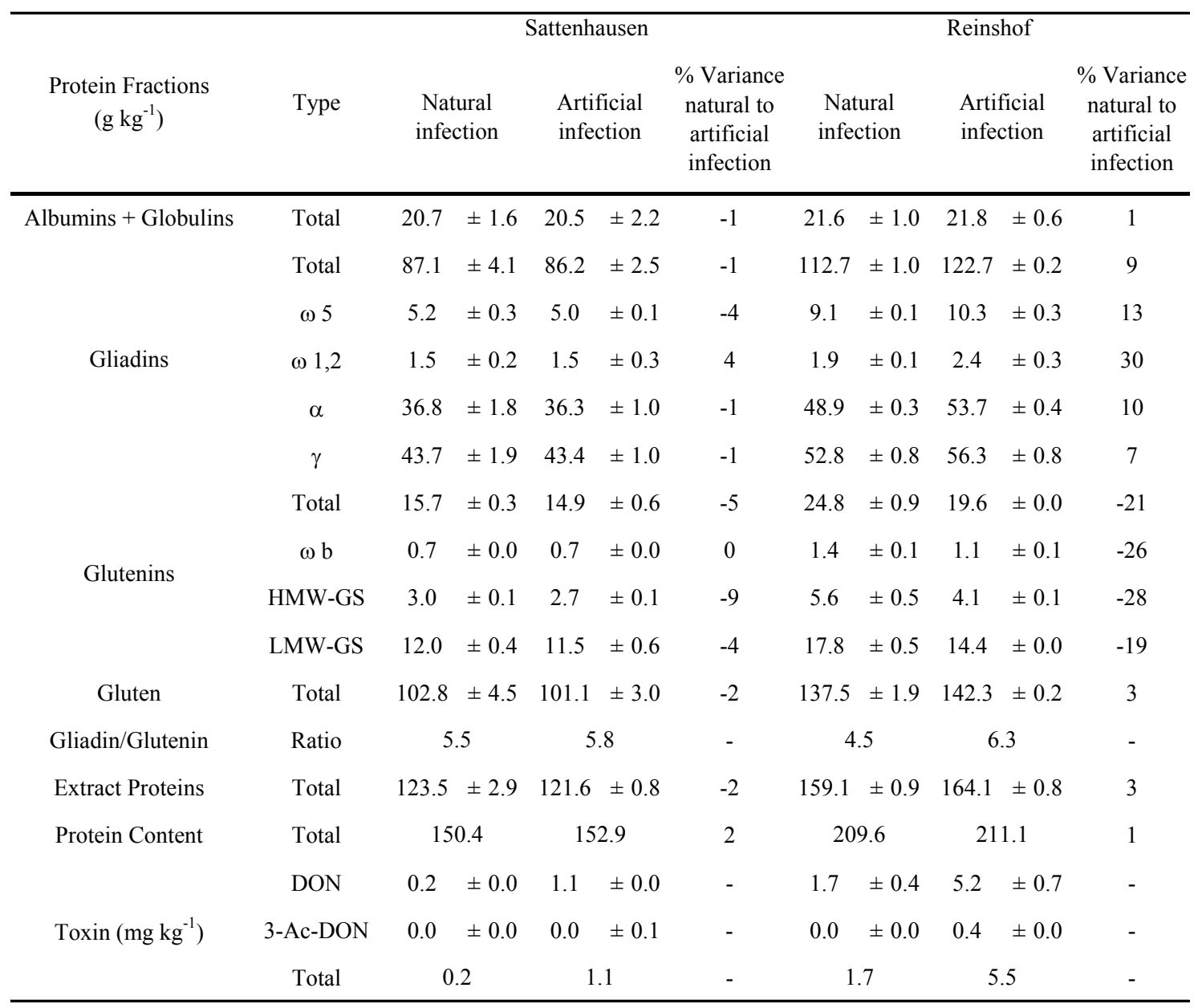


Table 1c Protein concentration $\left(\mathrm{g} \mathrm{kg}^{-1}\right)$ in naturally and artificially Fusarium infected grain from the emmer cultivar Klein and the relative variance between natural and artificial infection (\%) at the locations Sattenhausen and Reinshof as well as the DON and 3-Ac-DON concentration of the naturally and artificially infected grain

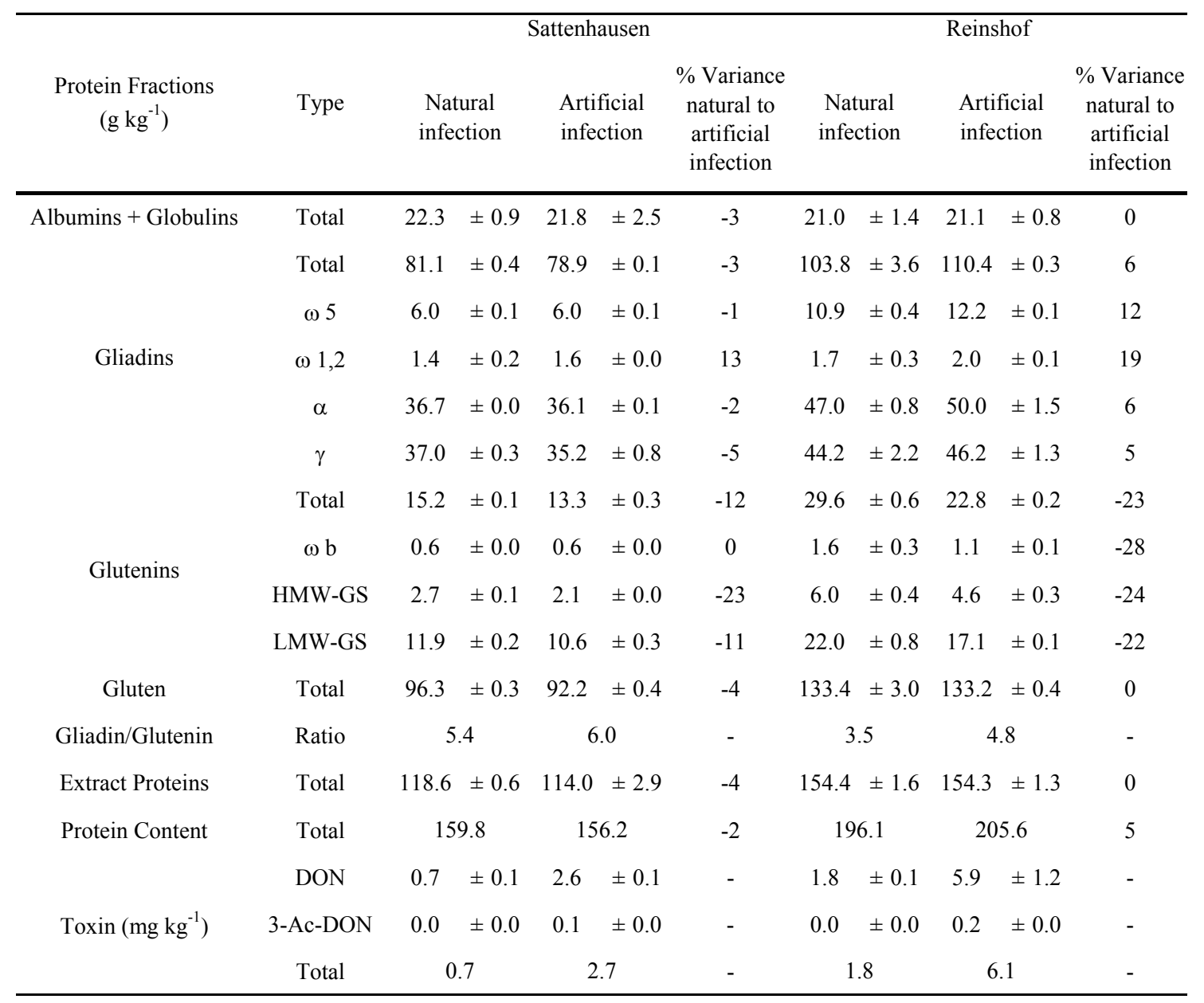


Table 1d Protein concentration $\left(\mathrm{g} \mathrm{kg}^{-1}\right)$ in naturally and artificially Fusarium infected grain from all three emmer cultivars (Far-108 + Hein-101, Klein, Linie 9-102) used in the study and the relative variance between natural and artificial infection (\%) at the locations Sattenhausen and Reinshof as well as the DON and 3-Ac-DON concentration of the naturally and artificially infected grain

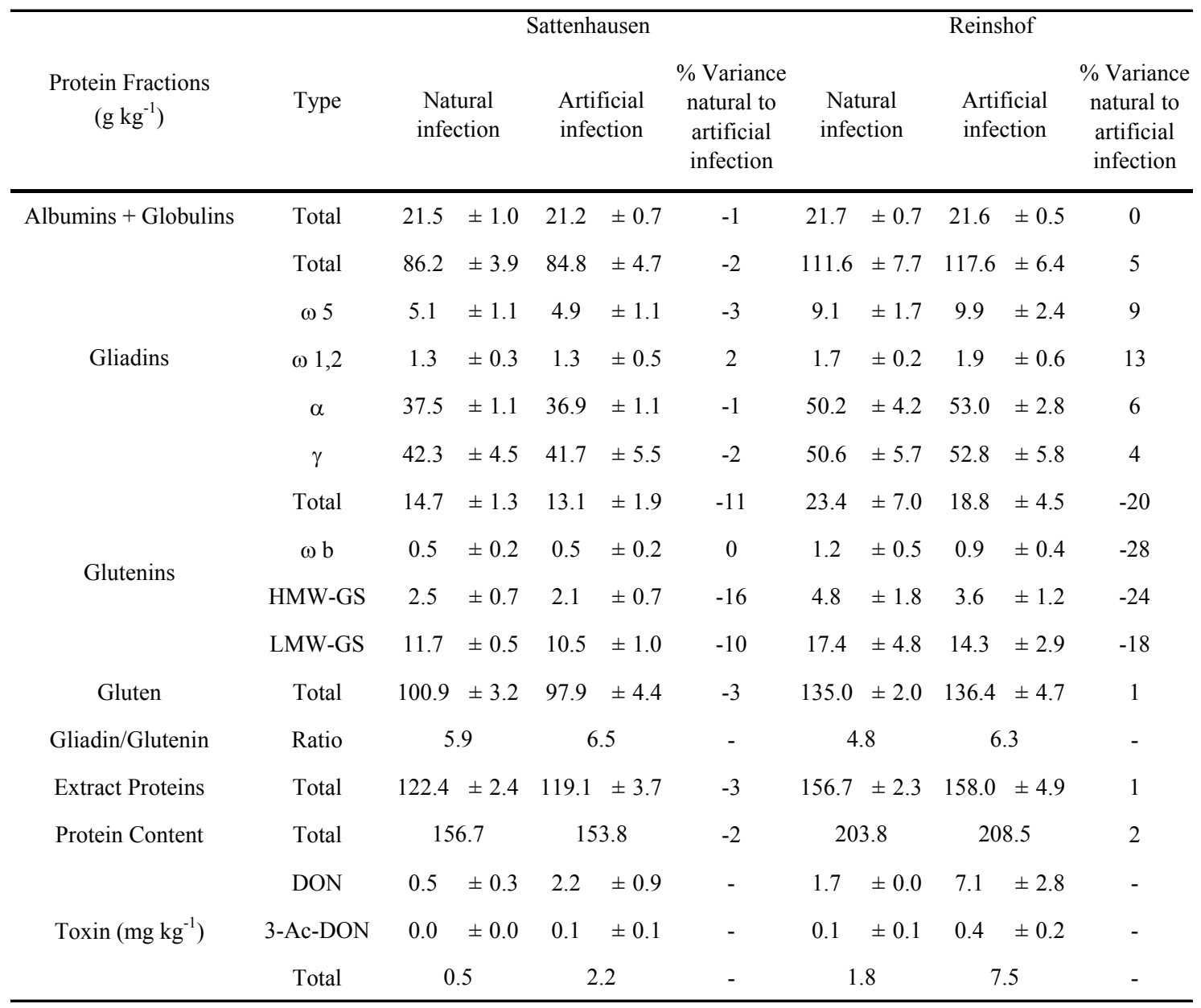

A comparison between emmer and wheat showed a $28 \%$ higher total protein and extractable protein content in emmer (Table 1f). A comparison of the total protein content and the amount of extractable protein showed that about $77 \%$ of the total protein content can be extracted by the method used in this study (Tables 1a-f). Nonextractable proteins are membrane associated or integrated basic proteins with a high sugar content [22] and nonextractable storage proteins. For a more complete extraction of the plant proteome special procedures must be used [23].

To quantify the contribution of Fusarium protein to the grain's proteins, the amount of soluble F. graminearum protein in the grain was determined as this is the most important fungus in Europe. We found 15\% soluble and 85\% insoluble F. graminearum 
protein and a total protein content of $18 \%$ for the fungus. With this information and the amount of soluble FPU detected by ELISA, we could conclude that the proportion of soluble Fusarium protein of the total protein even in strongly infected grains is relatively small: for emmer, a maximum of $0.13 \%$, and for wheat, $0.3 \%$ of the protein was of Fusarium origin (Table 2). A masking of the absolute grain protein content by Fusarium infection and reduced grain protein content due to the Fusarium infection can, therefore, be excluded.

Table 1e Protein concentration $\left(\mathrm{g} \mathrm{kg}^{-1}\right)$ in naturally and artificially Fusarium infected grain from the wheat cultivar Amaretto and the relative variance between natural and artificial infection (\%) at the locations Sattenhausen and Reinshof as well as the DON and 3-Ac-DON concentration of the naturally and artificially infected grain

\begin{tabular}{|c|c|c|c|c|c|c|c|c|c|c|c|}
\hline \multirow{3}{*}{$\begin{array}{c}\text { Protein Fractions } \\
\qquad\left(\mathrm{g} \mathrm{kg}^{-1}\right)\end{array}$} & \multirow{3}{*}{$\begin{array}{l}\text { Type } \\
\text { Total }\end{array}$} & \multicolumn{5}{|c|}{ Sattenhausen } & \multicolumn{5}{|c|}{ Reinshof } \\
\hline & & \multicolumn{2}{|c|}{$\begin{array}{l}\text { Natural } \\
\text { infection }\end{array}$} & \multicolumn{2}{|c|}{$\begin{array}{l}\text { Artificial } \\
\text { infection }\end{array}$} & \multirow{2}{*}{$\begin{array}{c}\% \text { Variance } \\
\text { natural to } \\
\text { artificial } \\
\text { infection }\end{array}$} & \multicolumn{2}{|c|}{$\begin{array}{l}\text { Natural } \\
\text { infection }\end{array}$} & \multicolumn{2}{|c|}{$\begin{array}{l}\text { Artificial } \\
\text { infection }\end{array}$} & \multirow{2}{*}{$\begin{array}{c}\% \text { Variance } \\
\text { natural to } \\
\text { artificial } \\
\text { infection }\end{array}$} \\
\hline & & 23.4 & \pm 0.4 & 22.1 & \pm 0.6 & & 23.4 & \pm 0.3 & 23.4 & \pm 0.1 & \\
\hline \multirow{5}{*}{ Gliadins } & Total & 61.9 & \pm 1.5 & 65.9 & \pm 0.6 & 6 & 62.6 & \pm 0.8 & 73.2 & \pm 0.5 & 17 \\
\hline & $\omega 5$ & 2.7 & \pm 0.1 & 2.9 & \pm 0.1 & 7 & 3.1 & \pm 0.1 & 3.5 & \pm 0.1 & 12 \\
\hline & $\omega 1,2$ & 5.7 & \pm 0.5 & 6.0 & \pm 0.3 & 6 & 6.8 & \pm 0.2 & 10.6 & \pm 0.1 & 57 \\
\hline & $\alpha$ & 22.5 & \pm 0.8 & 25.1 & \pm 0.2 & 11 & 23.7 & \pm 0.7 & 26.9 & \pm 0.1 & 14 \\
\hline & $\gamma$ & 31.0 & \pm 0.1 & 31.9 & \pm 0.6 & 3 & 29.0 & \pm 0.2 & 32.2 & \pm 0.8 & 11 \\
\hline \multirow{4}{*}{ Glutenins } & Total & 20.2 & \pm 0.8 & 11.6 & \pm 0.5 & -43 & 30.6 & \pm 0.2 & 17.0 & \pm 0.2 & -44 \\
\hline & $\omega b$ & 0.7 & \pm 0.1 & 0.5 & \pm 0.1 & -36 & 0.8 & \pm 0.1 & 0.6 & \pm 0.1 & -31 \\
\hline & HMW-GS & 5.0 & \pm 0.1 & 2.4 & \pm 0.2 & -53 & 9.3 & \pm 0.4 & 4.4 & \pm 0.5 & -52 \\
\hline & LMW-GS & 14.5 & \pm 0.8 & 8.7 & \pm 0.3 & -40 & 20.5 & \pm 0.5 & 12.0 & \pm 0.3 & -41 \\
\hline Gluten & Total & 82.1 & \pm 0.8 & 77.5 & \pm 0.1 & -6 & 94.2 & \pm 0.8 & 90.2 & \pm 0.4 & -4 \\
\hline Gliadin/Glutenin & Ratio & \multicolumn{2}{|c|}{3.1} & \multicolumn{2}{|c|}{5.7} & - & \multicolumn{2}{|c|}{2.0} & \multicolumn{2}{|c|}{4.1} & - \\
\hline Extract Proteins & Total & 105.5 & \pm 0.4 & 99.6 & \pm 0.6 & -6 & 116.6 & \pm 0.5 & 113.6 & \pm 0.3 & -3 \\
\hline \multirow[t]{2}{*}{ Protein Content } & Total & \multicolumn{2}{|c|}{135.0} & \multicolumn{2}{|c|}{136.6} & 1 & \multicolumn{2}{|c|}{147.2} & \multicolumn{2}{|c|}{145.8} & -1 \\
\hline & DON & 0.3 & \pm 0.0 & 2.1 & \pm 0.7 & - & 0.0 & \pm 0.0 & 3.6 & \pm 0.2 & - \\
\hline \multirow[t]{2}{*}{ Toxin $\left(\mathrm{mg} \mathrm{kg}^{-1}\right)$} & 3-Ac-DON & 0.0 & \pm 0.0 & 0.1 & \pm 0.0 & - & 0.0 & \pm 0.0 & 0.1 & \pm 0.0 & - \\
\hline & Total & \multicolumn{2}{|c|}{0.3} & \multicolumn{2}{|c|}{2.2} & - & \multicolumn{2}{|c|}{0.0} & \multicolumn{2}{|c|}{3.7} & - \\
\hline
\end{tabular}


Table 1f Summary of the protein concentration $\left(\mathrm{g} \mathrm{kg}^{-1}\right)$ in naturally and artificially Fusarium infected grain from all three emmer cultivars (Far-108 + Hein-101, Klein, Linie 9-102) and the wheat cultivar Amaretto with the relative variance between natural and artificial infection (\%) at both the Sattenhausen and Reinshof locations as well as the DON and 3-Ac-DON concentration of the naturally and artificially infected grain

\begin{tabular}{|c|c|c|c|c|c|c|c|c|c|}
\hline \multirow{3}{*}{$\begin{array}{l}\text { Protein Fractions } \\
\qquad\left(\mathrm{g} \mathrm{kg}^{-1}\right)\end{array}$} & \multirow{3}{*}{ Type } & \multicolumn{4}{|c|}{ Emmer $(n=3)$} & \multicolumn{4}{|c|}{ Wheat (Amaretto) } \\
\hline & & & ttenhausen $+\mathrm{Re}$ & inshof & & & Satten & hausen + Reinsl & lof \\
\hline & & $\begin{array}{l}\text { Natural } \\
\text { infection }\end{array}$ & $\begin{array}{l}\text { Artificial } \\
\text { infection }\end{array}$ & $\begin{array}{c}\% \text { Variance } \\
\text { natural to } \\
\text { artificial } \\
\text { infection }\end{array}$ & $\mathrm{p}^{\#}$ & $\begin{array}{l}\mathrm{Na} \\
\text { infe }\end{array}$ & $\begin{array}{l}\text { ural } \\
\text { ction }\end{array}$ & $\begin{array}{l}\text { Artificial } \\
\text { infection }\end{array}$ & $\begin{array}{c}\% \text { Variance } \\
\text { natural to } \\
\text { artificial } \\
\text { infection }\end{array}$ \\
\hline \multirow[t]{3}{*}{ Albumins + Globulins } & Total & $21.6 \pm 0.6$ & $21.4 \pm 0.5$ & -0.8 & 0.18 & 23.4 & \pm 0 & $22.7 \pm 0.8$ & -2.6 \\
\hline & Total & $98.9 \pm 14.3$ & $101.3 \pm 17.9$ & 2.4 & 0.25 & 62.2 & \pm 0.41 & $69.6 \pm 2.3$ & 11.8 \\
\hline & $\omega 5$ & $7.1 \pm 2.5$ & $7.4 \pm 3.1$ & 4.5 & 0.31 & 2.9 & \pm 0.25 & $3.2 \pm 0.4$ & 9.9 \\
\hline \multirow[t]{4}{*}{ Gliadins } & $\omega 1,2$ & $1.5 \pm 0.3$ & $1.6 \pm 0.6$ & 7.8 & 0.39 & 6.2 & \pm 0.64 & $8.3 \pm 2.7$ & 33.4 \\
\hline & $\alpha$ & $43.8 \pm 7.1$ & $45.0 \pm 8.6$ & 2.6 & 0.24 & 23.1 & \pm 0.67 & $26.0 \pm 1.0$ & 12.5 \\
\hline & $\gamma$ & $46.5 \pm 6.2$ & $47.3 \pm 7.6$ & 1.7 & 0.29 & 30.0 & \pm 1.15 & $32.1 \pm 0.1$ & 7.0 \\
\hline & Total & $19.1 \pm 6.3$ & $15.9 \pm 4.2$ & -16.3 & 0.02 & 25.5 & \pm 6 & $14.3 \pm 3.2$ & -43.9 \\
\hline \multirow{3}{*}{ Glutenins } & $\omega b$ & $0.9 \pm 0.5$ & $0.7 \pm 0.3$ & -19.4 & 0.10 & 0.8 & \pm 0.07 & $0.5 \pm 0.1$ & -33.3 \\
\hline & HMW-GS & $3.6 \pm 1.7$ & $2.9 \pm 1.2$ & -21.6 & 0.02 & 7.2 & \pm 2.45 & $3.4 \pm 1.2$ & -52.5 \\
\hline & LMW-GS & $14.6 \pm 4.2$ & $12.4 \pm 2.7$ & -14.8 & 0.03 & 17.5 & \pm 3.48 & $10.4 \pm 1.9$ & -40.8 \\
\hline Gluten & Total & $118.0 \pm 18.0$ & $117.2 \pm 20.5$ & -0.7 & 0.59 & 87.7 & \pm 7.07 & $83.9 \pm 5.5$ & -4.3 \\
\hline Gliadin/Glutenin & Ratio & 5.2 & 6.4 & - & - & \multicolumn{2}{|c|}{2.4} & 4.9 & - \\
\hline Extract Proteins & Total & $139.6 \pm 18.0$ & $138.6 \pm 20.7$ & -0.7 & 0.73 & \multicolumn{2}{|c|}{$111.1 \pm 6.4$} & $106.6 \pm 6.3$ & -4.0 \\
\hline Protein & Total & 180.2 & 178.8 & -0.8 & 0.54 & \multicolumn{2}{|c|}{141.1} & 141.2 & 0.1 \\
\hline \multirow[b]{2}{*}{ Toxin $\left(\mathrm{mg} \mathrm{kg}^{-1}\right)$} & DON & $1.1 \pm 0.7$ & $4.6 \pm 3.3$ & - & - & 0.2 & \pm 0.0 & $2.9 \pm 1.1$ & - \\
\hline & $\begin{array}{c}\text { 3-Ac-DON } \\
\text { Total }\end{array}$ & $\begin{array}{ll}0.0 \quad \pm 0.0 \\
1.1\end{array}$ & $\begin{array}{l}0.2 \pm 0.2 \\
4.9\end{array}$ & $\begin{array}{l}- \\
-\end{array}$ & $\begin{array}{l}- \\
-\end{array}$ & $\begin{array}{r}0.0 \\
0\end{array}$ & $\begin{array}{l} \pm 0.0 \\
.2\end{array}$ & $\begin{array}{cc}0.1 & \pm 0.0 \\
& 2.9\end{array}$ & - \\
\hline
\end{tabular}

\# $\mathrm{p}=$ significance of difference between natural and artificial infected emmer cultivars on both locations

The influence of Fusarium infection on the Osborne fractions in emmer and wheat showed that the albumin and globulin fraction was not significantly changed by the presence of Fusarium infection (Table 1a-f). Based on the total extractable protein, the albumin and globulin fraction in emmer formed, with $15 \%$, a six percent lower proportion of the total extractable protein than this fraction in wheat. This may be due to either the higher content of this fraction in wheat in comparison to emmer or to there being a better extractability of gliadin and glutenin in emmer. 
The gliadin and glutenin fractions and types were influenced by Fusarium infection (Tables 1a-f). For gliadins, the content of all types increased after artificial infection in comparison to the naturally infected wheat samples (Table 1e). In comparison, this effect was less clear in emmer after artificial infection as only the samples from the location RH with the stronger infection degree (based on the amount of Fusarium toxin) showed this effect (Tables 1a-d; Figure 2). In contrast to gliadin, the glutenin content in the artificially infected samples showed a significant reduction of its main subunits HMW-GS and LMW-GS in both the emmer (Table 1f) and the summer wheat cultivar (Figure 2). The glutenin-bound $\omega b$-gliadins were also reduced, but not significantly. Therefore, we can conclude that a destruction of the glutenin fraction arises related to the infection (Table 1d). A comparison between the results for emmer and wheat (Tables 1d-e; Figure 2) indicates that the glutenin fractions and types are more strongly affected by Fusarium infection in wheat than in emmer in spite of the lower degree of infection found in the wheat.

Table 2 Fusarium Protein Units (FPU) in naturally and artificially Fusarium infected grain flour (summarized data from both locations)

\begin{tabular}{cccccc}
\hline \multirow{2}{*}{ Species } & \multirow{2}{*}{ Cultivar } & \multicolumn{5}{c}{ FPU $\left(\mathrm{g} \mathrm{kg}^{-1}\right)$} \\
& & Natural & \\
& Linfection $9-102$ & 0.01 & \pm 0.01 & 0.13 & \pm 0.16 \\
& far-108+Hein-101 & 0.01 & \pm 0.01 & 0.19 & \pm 0.27 \\
Emmer & Klein & 0.00 & \pm 0.00 & 0.22 & \pm 0.25 \\
& $(\mathrm{n}=3)$ & 0.01 & \pm 0.01 & 0.18 & \pm 0.18 \\
& Amaretto & 0.00 & \pm 0.00 & 0.43 & \pm 0.02 \\
\hline \multirow{2}{*}{ Wheat } & & & & & \\
\hline
\end{tabular}


Table 3 Variance of the relative protein concentration between the two locations, Sattenhausen and Reinshof, from the three emmer cultivars (Far-108 + Hein-101, Klein, Linie 9-102) and the wheat cultivar Amaretto dependent on N supply

\begin{tabular}{|c|c|c|c|}
\hline Protein Fractions & Type & $\begin{array}{c}\text { Emmer } \\
(n=3)\end{array}$ & $\begin{array}{l}\text { Wheat } \\
(n=1)\end{array}$ \\
\hline \multirow[t]{3}{*}{ Albumin/Globulin } & Total & 1.1 & 3.0 \\
\hline & Total & 34.1 & 3.7 \\
\hline & $\omega 5$ & 91.6 & 18.6 \\
\hline \multirow[t]{4}{*}{ Gliadins } & $\omega 1,2$ & 38.4 & 49.0 \\
\hline & $\alpha$ & 38.7 & 6.2 \\
\hline & $\gamma$ & 23.1 & -2.8 \\
\hline & Total & 51.1 & 49.9 \\
\hline \multirow{3}{*}{ Glutenins } & $\omega b$ & 93.1 & 21.2 \\
\hline & HMW-GS & 85.1 & 84.5 \\
\hline & LMW-GS & 42.1 & 40.2 \\
\hline Gluten & Total & 36.5 & 13.6 \\
\hline Extract Proteins & Total & 30.2 & 10.7 \\
\hline Protein & Total & 32.8 & 7.9 \\
\hline
\end{tabular}

Although the total gluten content did not change significantly, the ratio between gliadin and glutenin content changed according to the extent of the infection in favour of gliadin. The relationship between the ratios of emmer and wheat showed a twice as high ratio for emmer compared to wheat (Table 1f). This result is confirmed by an earlier study on wheat which also described an increase in the gliadins and a decrease in glutenin content in this cereal [11]. The explanations given for this include that the changes in glutenin synthesis during the later stages of kernel maturation occur largely due to a reduced protein synthesis invoked by Fusarium infection and the inhibition of 
protein synthesis by the accumulation of DON $[5,8,11]$. In contrast, another study found no gliadin and glutenin monomer synthesis at different maturation stages; just polymeric glutenin formation was detected in the later stages [12].

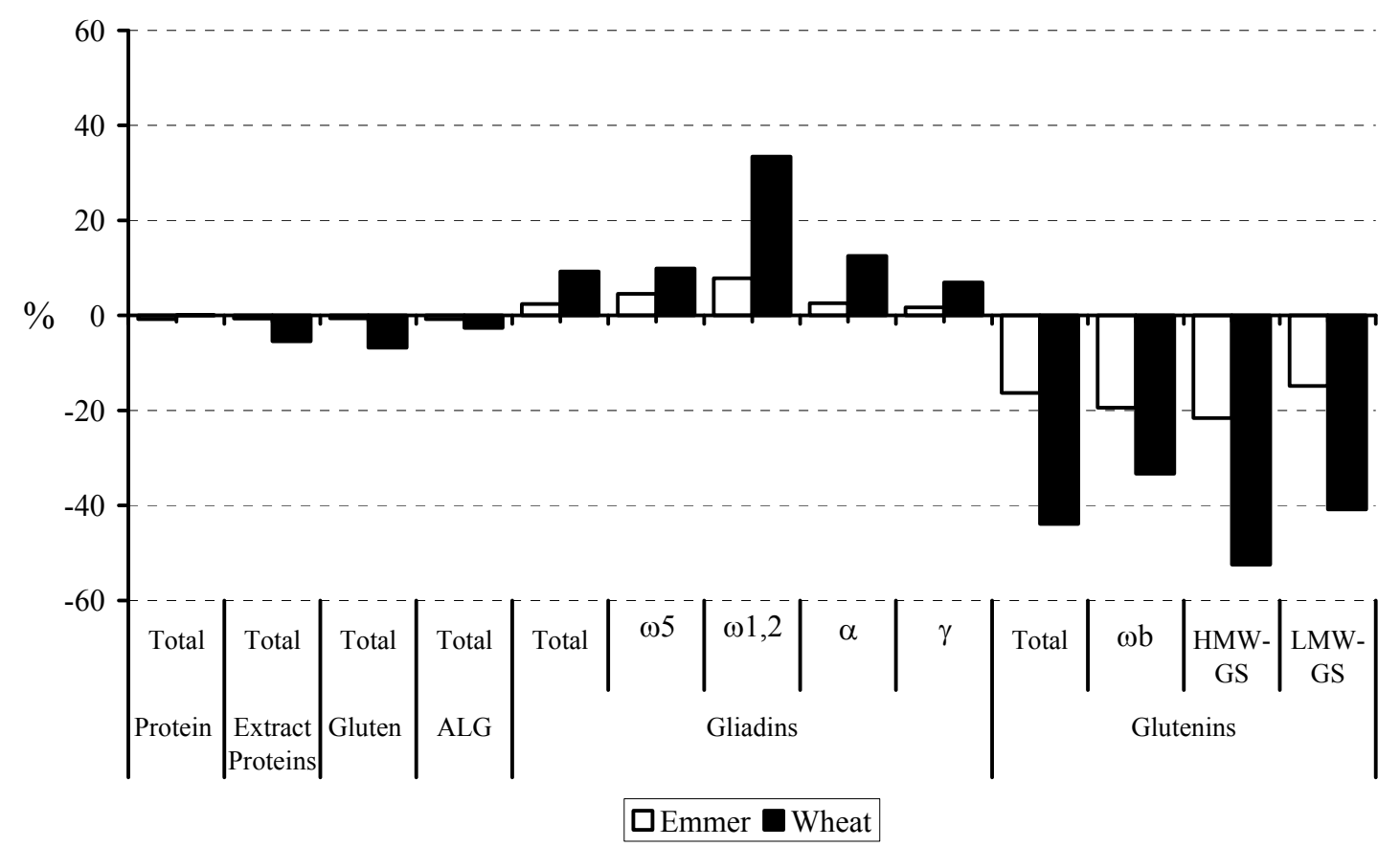

Figure 2 Variations in percent of protein fractions and types in the whole flour from the three emmer cultivars and the wheat cultivar from two growing locations after artificial Fusarium infection in comparison to natural infection

For the present results, we have assumed an enzymatic degradation of the glutenin subunits by the fungal proteases. Such proteases of the Fusarium spp. exoproteome include trypsin-like protease or serine protease, which are known to be proteindegrading enzymes [24-26]. The fragments released by this degradation are most likely to be more soluble in $60 \%$ ethanol, so that we could identify the glutenin fragments during the extraction step for the gliadin fraction. This would have led finally to the higher gliadin and lower glutenin contents found in the artificially infected samples in comparison to the naturally infected samples (Tables 1a-f; Figure 2) [26].

A comparison of the emmer and wheat also indicated that in spite of the stronger infection present in the emmer, the glutenin degradation was not as high as in wheat. The reasons for this effect may be the existence or higher expression of protease inhibitors (serine proteinase inhibitors) in emmer than in wheat [27].

All in all, the comparison of the emmer and wheat gluten fractions showed that the gliadin fraction is the main fraction in both species (emmer: $71 \%$; wheat: $56 \%$ ), but that 
emmer had a 50\% higher content than wheat. The glutenin fractions in emmer are present in the same quantities as in wheat (Tables 1a-f). The higher gliadin content in emmer found in this study maybe a result of enhanced gene expression based on upstream factors of the gene, which result in a higher gliadin/glutenin ratio in comparison to wheat $[28,29]$.

Effect of $N$ supply at two different locations on the protein content

The emmer cultivars showed at both locations ( $\mathrm{SH}$ and $\mathrm{RH}$ ) a 30\% higher protein content than in the wheat (Tables 1a-f). The protein contents found in the emmer in this study were $2-7 \%$ higher than those found in the literature [9]. The total protein content in emmer seems to be significantly connected to the conditions present at the growing location (Figures 3-5), which is supported by the results of the investigated wheat cultivar. The results for the wheat in this investigation confirm the results from a previous study [19].

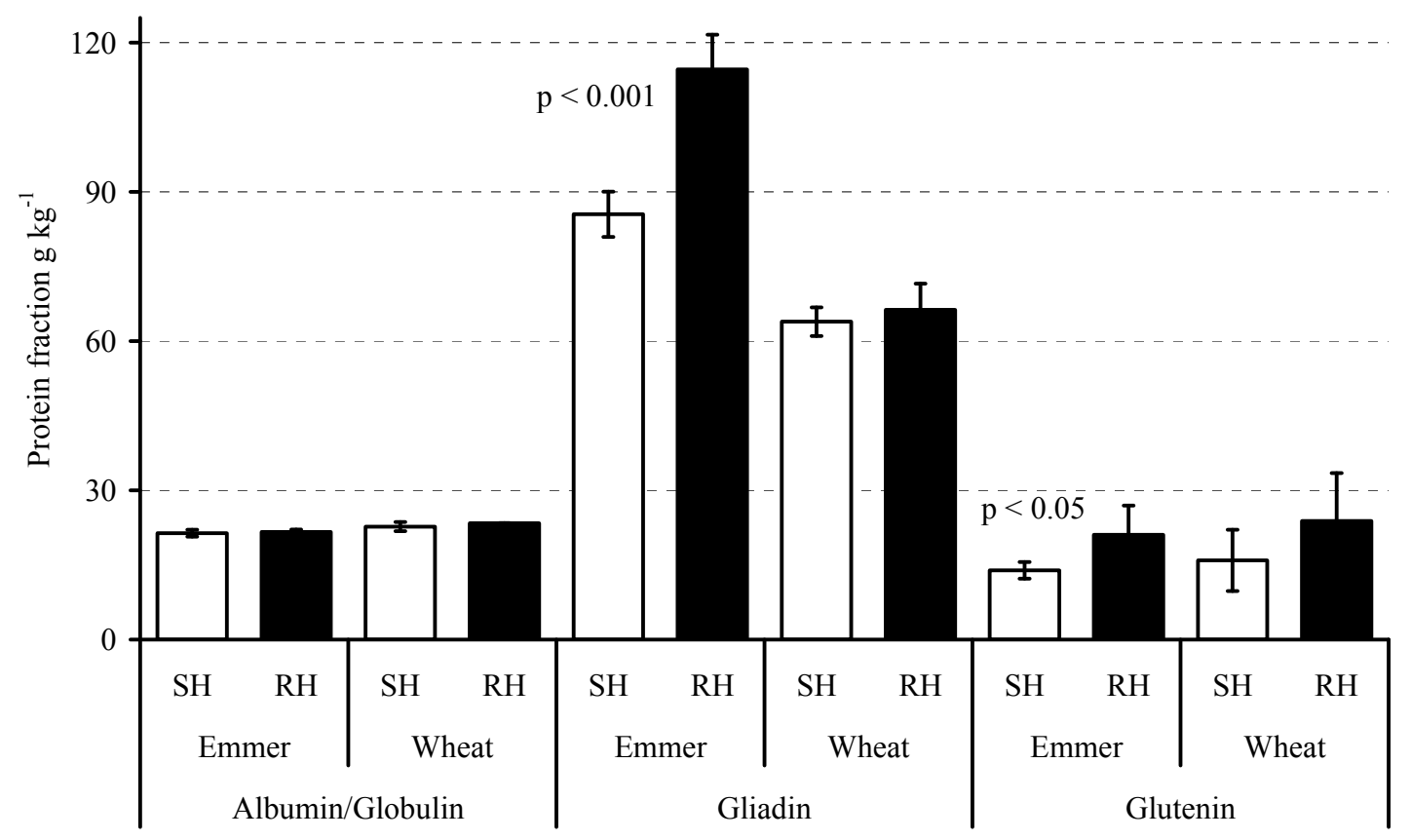

Figure 3 Quantities of protein fractions in emmer $(n=3)$ and wheat cultivar at two locations (SH: Sattenhausen; RH: Reinshof) according to the N supply (RH $>\mathrm{SH})$; the significant changes for emmer are denoted as p-values

For the impact of the location on the extracted protein fractions in emmer and wheat, we considered both the naturally and artificially fungal infected samples together. The emmer showed a $30 \%$ and wheat an $8 \%$ higher total protein content at $\mathrm{RH}$ than at $\mathrm{SH}$ (Table 3). The percentage distribution of the different proteins showed that the gluten 
content rose but the amount of albumins and globulins was just marginally affected by the location - the total content in $\mathrm{g} \mathrm{x} \mathrm{kg}^{-1}$ was only changed by about $1-3 \%$ (Table 3 , Figure 3). This effect has also been described for wheat in the literature $[15,28]$. Albumins and globulins are mainly metabolic and structural proteins [30] and have functions in cell metabolism. There is a minimum amount of these compounds needed for these functions, but no increase in content occurs with respect to the $\mathrm{N}$ supply.

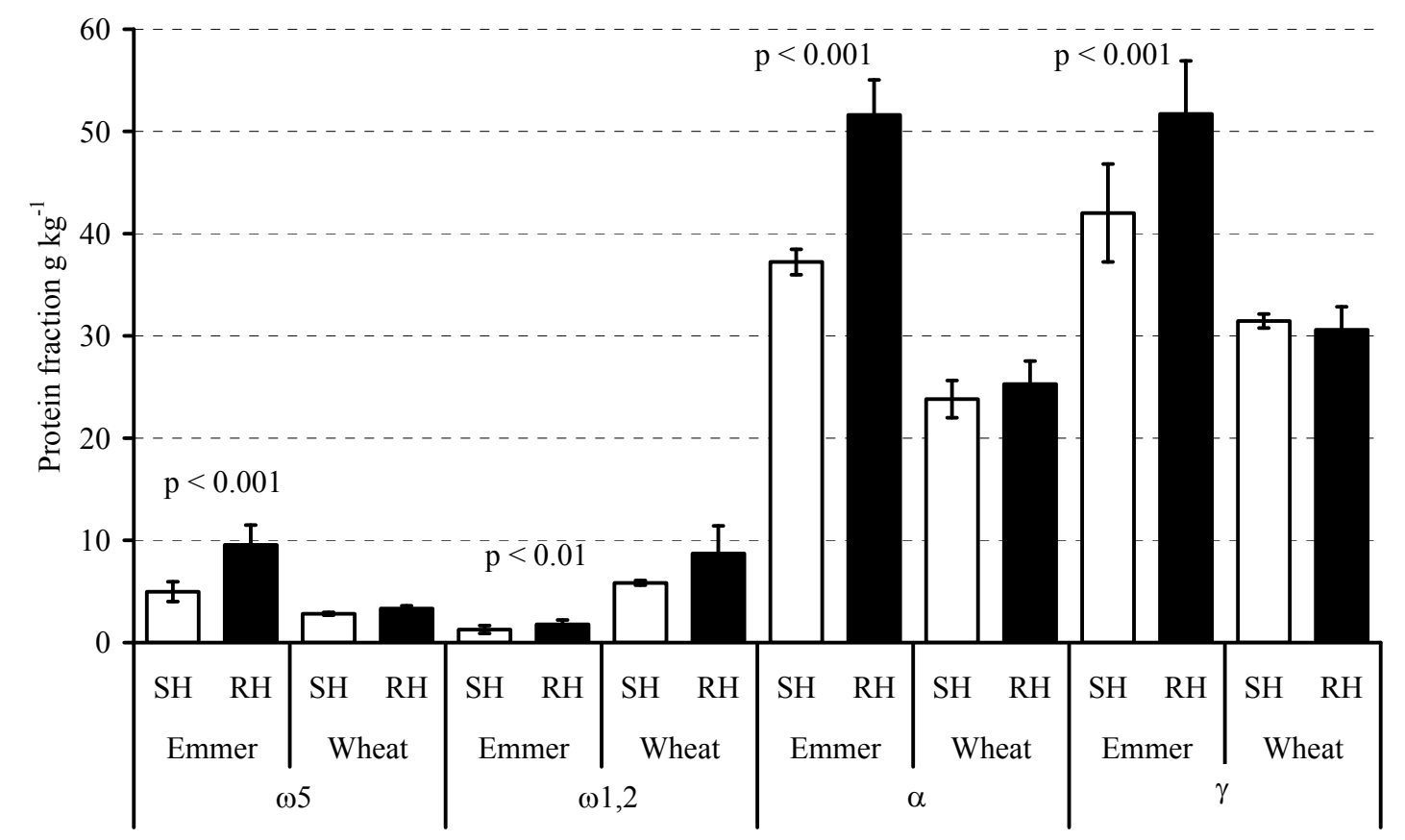

Figure 4 Quantities of gliadin types in three emmer cultivars and a wheat cultivar at two locations (SH: Sattenhausen; RH: Reinshof) dependent on the N supply (RH $>\mathrm{SH})$; significant changes for emmer are denoted as p-values 


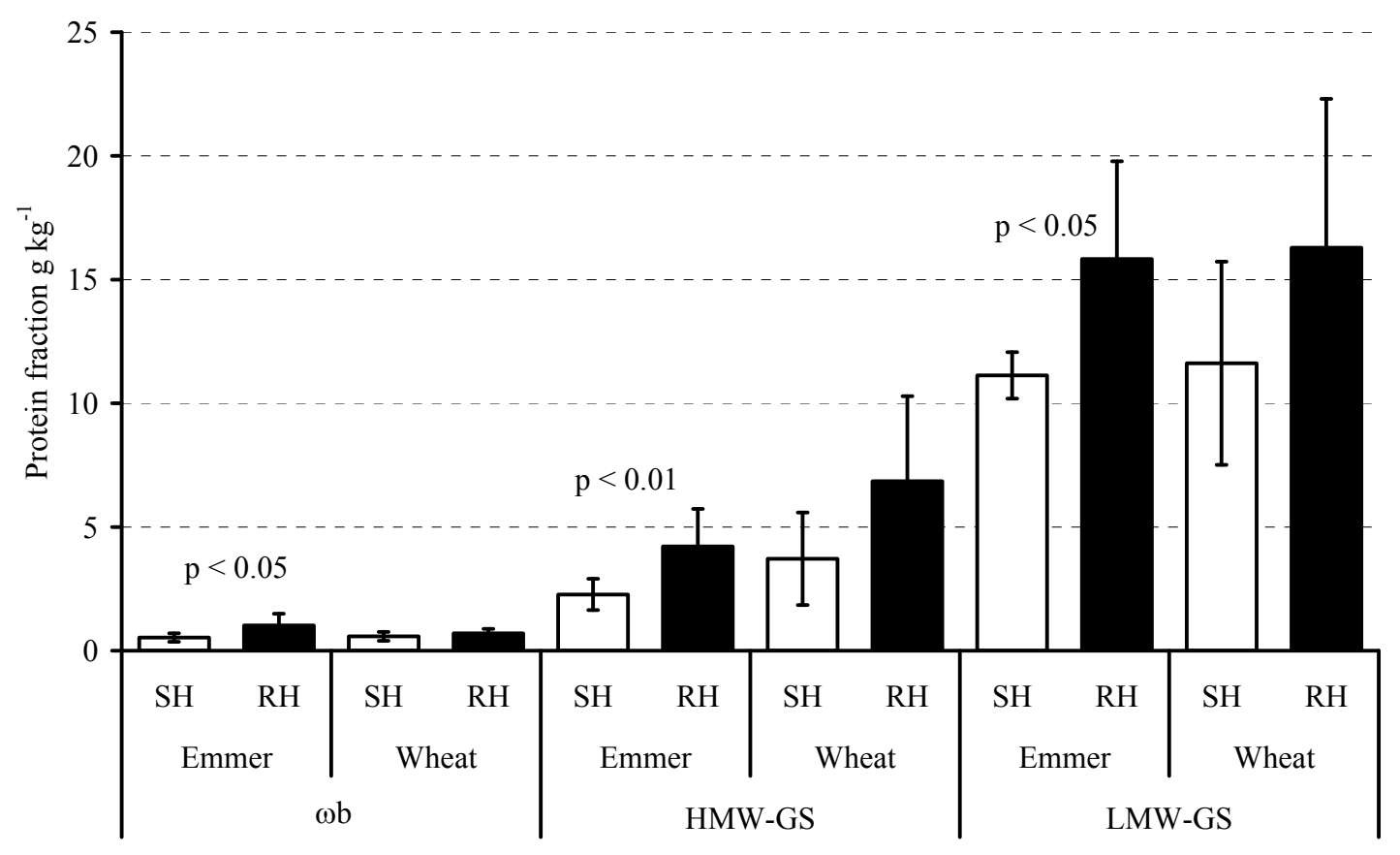

Figure 5 Quantities of glutenin types in emmer $(n=3)$ and wheat cultivar at two locations (SH: Sattenhausen; RH: Reinshof) dependent on N supply (RH $>\mathrm{SH}$ ); significant changes for emmer are denoted as p-values

The gliadin content $\left(\mathrm{g} \mathrm{x} \mathrm{kg}^{-1}\right)$ in emmer changed significantly (Figure 3): at $\mathrm{RH} 36 \%$ more gliadin was found in the grain than at $\mathrm{SH}$ and the glutenin content was also about $50 \%$ higher at RH (Table 3). Comparing the emmer to wheat, it can be said that the emmer storage proteins were more affected by the $\mathrm{N}$ supply at the location than wheat as the gliadin fraction in wheat was not or just minimally affected (Figure 4, Table 3). In contrast, the wheat's glutenin fraction was affected in the same range as in the emmer (Figure 5, Table 3). A consequence of these species-specific changes on the gluten fractions according to $\mathrm{N}$ supply is that the gliadin/glutenin ratio in wheat is more affected than in emmer (Tables 1d-e), which could result in positive effects on its breadmaking quality $[28,31]$. The reason for this difference in sensibility to $\mathrm{N}$ supply is possibly due to a regulation of synthesis. $\mathrm{N}$ availability and the resulting higher total protein content has been documented as a factor that can promote gene expression in other cereals like wheat or maize [29]. Hypothetically, raised $\mathrm{N}$ levels in emmer cultivars leads to a more enhanced gene expression of the storage proteins than in wheat. 


\section{Conclusions}

Emmer, normally grown under organic farming conditions, showed similar characteristics to wheat cultivars in their response to Fusarium spp. infection. In addition to the basic findings, new cognitions on the degradation and changes of protein subunits were found. Therefore, further investigations with a greater focus on protein degradation can be recommended. The influence of the growing location on cereal protein content has been well documented in previous studies on wheat. The present results showed that this is also true in emmer, although there were differences between emmer and wheat. Further studies in this context may clarify the mechanisms that lead to the irregular synthesis of emmer protein subunits in comparison to wheat as a result of a mixed Fusarium infection and differing nitrogen availability.

\section{Abbreviations used}

ALG, albumins and globulins; FPU, Fusarium protein units; HMW-GS, high molecular weight glutenin subunits; LMW-GS, low molecular weight glutenin subunits; PRproteins, pathogenesis-related proteins; $\mathrm{p}$, significance factor; RT, room temperature; TFA, trifluoroacetic acid

\section{Acknowledgements}

This work is part of the FAEN Joint Project 3 "Quality-related plant production under modified basic conditions: mycotoxins in the context of production, quality and processing", financed by the Ministry of Science and Culture of Lower Saxony, Germany. Special thanks are given to the grower Eckard Irion, Verein für Pflanzenzucht, Hof Grub e.V., who provided the seeds for this research trial as well as to the group of Prof. Petr Karlovsky, and especially to Sasithorn Limsuwan, Molecular Phytopathology and Mycotoxin Research, Department of Crop Science, Georg-August University Goettingen for the toxin analysis as well as to Dr. Joachim Weinert, Department of Crop Science, Georg-August University Goettingen for the Biotin/Avidin ELISA and Alexandra Axthelm for HPLC protein analysis. 


\section{References}

1. Bottalico A.; Perrone G., (2002), Toxigenic Fusarium species and mycotoxins associated with head blight in small-grain cereals in Europe. European Journal of Plant Pathology 108: 611-624.

2. Buerstmayr H.; Stierschneider M.; Steiner B.; Lemmens M.; Griesser M.; Nevo E.; Fahima T., (2003),Variation for resistance to head blight caused by Fusarium graminearum in wild emmer (Triticum dicoccoides) originating from Israel. Euphytica 130: 17-23.

3. Ramirez M. L.; Reynoso M. M.; Farnochi M. C.; Chulze S., (2006), Vegetative compatibility and mycotoxin chemotypes among Fusarium graminearum (Gibberella zeae) isolates from wheat in Argentina. European Journal of Plant Pathology 115: 139-148.

4. $\quad$ Yang L.; van der Lee T.; Yang X.; Yu D.; Waalwijk C., (2008),Fusarium populations on chinese barley show a dramatic gradient in mycotoxin profiles. Phytopathology 98: 719-727.

5. Eriksen G. S.; Pettersson H., (2004),Toxicological evaluation of trichothecenes in animal feed. Animal Feed Science and Technology 114: 205-239.

6. Thuvander A.; Wikman C.; Gadhasson I., (1999),In vitro exposure of human lymphocytes to trichothecenes: Individual variation in sensitivity and effects of combined exposure on lymphocyte function. Food and Chemical Toxicology 37: 639-648.

7. Tsuda S.; Kosaka Y.; Murakami M.; Matsuo H.; Matsusaka N.; Taniguchi K.; Sasaki Y. F., (1998),Detection of nivalenol genotoxicity in cultured cells and multiple mouse organs by the alkaline single-cell gel electrophoresis assay. Mutat. Res. Genet. Toxicol. Environ. Mutagen. 415: 191-200.

8. Yabe T.; Hashimoto H.; Sekijima M.; Degawa M.; Hashimoto Y.; Tashiro F.; Ueno Y., (1993),Effects of Nivalenol on Hepatic Drug-Metabolizing Activity in Rats. Food and Chemical Toxicology 31: 573-581.

9. Wieser H., (2000), Comparative investigations of gluten proteins from different wheat species I. Qualitative and quantitative composition of gluten protein types. Eur. Food Res. Technol. 211: 262-268.

10. Boyacioglu D.; Hettiarachchy N. S., (1995), Changes in Some Biochemical-Components of Wheat-Grain That Was Infected with Fusarium-Graminearum. Journal of Cereal Science 21: $57-62$.

11. Wang J. H.; Wieser H.; Pawelzik E.; Weinert J.; Keutgen A. J.; Wolf G. A., (2005),Impact of the fungal protease produced by Fusarium culmorum on the protein quality and breadmaking properties of winter wheat. Eur. Food Res. Technol. 220: 552-559.

12. Abonyi T.; Kiraly I.; Tomoskozi S.; Baticz O.; Guoth A.; Gergely S.; Scholz E.; Lasztity D.; Lasztity R., (2007),Synthesis of gluten-forming polypeptides. 1. Biosynthesis of gliadins and glutenin subunits. Journal of Agricultural and Food Chemistry 55: 3655-3660.

13. Prange A.; Modrow H.; Hormes J.; Kramer J.; Kohler P., (2005),Influence of mycotoxin producing fungi (Fusarium, Aspergillus, Penicillium) on gluten proteins during suboptimal storage of wheat after harvest and competitive interactions between field and storage fungi. Journal of Agricultural and Food Chemistry 53: 6930-6938.

14. Benetrix F.; Sarrafi A.; Autran J. C., (1994),Effects of Genotype and Nitrogen Nutrition on Protein Aggregates in Barley. Cereal Chemistry 71: 75-82.

15. Pechanek U.; Karger A.; Groger S.; Charvat B.; Schoggl G.; Lelley T., (1997),Effect of nitrogen fertilization on quantity of flour protein components, dough properties, and breadmaking quality of wheat. Cereal Chemistry 74: 800-805.

16. Ndong C.; Danyluk J.; Wilson K. E.; Pocock T.; Huner N. P. A.; Sarhan F., (2002),Cold-regulated cereal chloroplast late embryogenesis abundant-like proteins. Molecular characterization and functional analyses. Plant Physiol 129: 1368-81.

17. Adejumo T. O.; Hettwer U.; Karlovsky P., (2007), Occurrence of Fusarium species and trichothecenes in Nigerian maize. Int. J. Food Microbiol. 116: 350-357. 
18. Tian S. M.; Wolf G. A.; Weinert J., (2005),Accurate assessment of wheat and triticale cultivar resistance to Septoria tritici and Stagonospora nodorum infection by biotin/avidin ELISA. Plant Disease 89: 1229-1234.

19. Wieser H.; Antes S.; Seilmeier W., (1998), Quantitative determination of gluten protein types in wheat flour by reversed-phase high-performance liquid chromatography. Cereal Chemistry 75: 644-650.

20. van Eckert R.; Berghofer E.; Ciclitira P. J.; Chirdo F.; Denery-Papini S.; Ellis H. J.; Ferranti P.; Goodwin P.; Immer U.; Mamone G.; Mendez E.; Mothes T.; Novalin S.; Osman A.; Rumbo M.; Stern M.; Thorell L.; Whim A.; Wieser H., (2006), Towards a new gliadin reference material-isolation and characterisation. Journal of Cereal Science 43: 331-341.

21. Oliver R. E.; Stack R. W.; Miller J. D.; Cai X., (2007), Reaction of wild emmer wheat accessions to Fusarium head blight. Crop Science 47: 893-899.

22. Gottlieb D. M.; Schultz J.; Bruun S. W.; Jacobsen S.; Sondergaard I., (2004),Multivariate approaches in plant science. Phytochemistry 65: 1531-1548.

23. Canovas F. M.; Dumas-Gaudot E.; Recorbet G.; Jorrin J.; Mock H. P.; Rossignol M. In Plant proteome analysis, 2004; Wiley-V C H Verlag Gmbh: 2004; pp 285-298.

24. Phalip V.; Delalande F.; Carapito C.; Goubet F.; Hatsch D.; Leize-Wagner E.; Dupree P.; Van Dorsselaer A.; Jeltsch J. M., (2005),Diversity of the exoproteome of Fusarium graminearum grown on plant cell wall. Current Genetics 48: 366-379.

25. Pekkarinen A.; Mannonen L.; Jones B. L.; Niku-Paavola M. L., (2000),Production of proteases by Fusarium species grown on barley grains and in media containing cereal proteins. Journal of Cereal Science 31: 253-261.

26. Pekkarinen A. I.; Jones B. L., (2002), Trypsin-like proteinase produced by Fusarium culmorum grown on grain proteins. Journal of Agricultural and Food Chemistry 50: 3849-3855.

27. Pekkarinen A. I.; Longstaff C.; Jones B. L., (2007),Kinetics of the inhibition of Fusarium serine proteinases by barley (Hordeum vulgare L.) inhibitors. Journal of Agricultural and Food Chemistry 55: 2736-2742.

28. Johansson E.; Prieto-Linde M. L.; Jonsson J. O., (2001),Effects of wheat cultivar and nitrogen application on storage protein composition and breadmaking quality. Cereal Chemistry 78: $19-25$.

29. Shewry P. R.; Halford N. G., (2002), Cereal seed storage proteins: structures, properties and role in grain utilization. Journal of Experimental Botany 53: 947-958.

30. Merlino M.; Leroy P.; Chambon C.; Branlard G., (2009),Mapping and proteomic analysis of albumin and globulin proteins in hexaploid wheat kernels (Triticum aestivum L.). Theor. Appl. Genet. 118: 1321-1337.

31. Uthayakumaran S.; Gras P. W.; Stoddard F. L.; Bekes F., (1999),Effect of varying protein content and glutenin-to-gliadin ratio on the functional properties of wheat dough. Cereal Chemistry 76: 389-394. 


\title{
5.4 The influence of Fusarium infection and growing location on the quantitative protein composition of (Part II) naked barley (Hordeum vulgare nudum)
}

Kai Eggert, Herbert Wieser, Elke Pawelzik, European Food Research and Technology (2010), 230: 893-902

\begin{abstract}
The effect of the fungal infection Fusarium graminearum and Fusarium culmorum on naked barley cultivars $(n=7)$ with respect to the barley's total protein content and the content of the protein fractions albumins + globulins, prolamins (hordeins) and glutelins (hordenins) was investigated. A summer barley cultivar $(n=1)$ was used for comparison. The total protein content of the whole grain flours was very variable, ranging from 125 to $225 \mathrm{~g} \mathrm{~kg}^{-1}$. The influence of Fusarium infection showed that the content of hordeins and hordenins was slightly reduced, while the albumins and globulins were not affected. In addition, the effect of the two different growing locations on the protein content of the naked barley was also evaluated. It could be shown that the C-hordeins, $\gamma$-hordeins and D-hordenins were significantly positively affected by increasing nitrogen supply, whereas the B-hordenin content was significantly negatively influenced. Nitrogen availability seems to be a factor which promotes gene expression for hordeins, but reduces the synthesis of the main Bhordenins.
\end{abstract}

Keywords: Barley, Fusarium, Protein composition, Deoxynivalenol (DON)

\section{Introduction}

Fusarium graminearum and Fusarium culmorum infection of cereal grains, like wheat and barley, leads to pathogenic effects on the plant and spike. These can result in dramatic yield and quality losses (Bottalico \& Perrone, 2002, Buerstmayr et al., 2003). Fusarium head blight (FHB) is the visible effect of this fungal infection and a problem known throughout the world (Bottalico \& Perrone, 2002, Ramirez et al., 2006, Yang et al., 2008). The two aforementioned Fusarium species are producers of trichothecene mycotoxins such as deoxynivalenol (DON), 3- and 15-acetyldeoxynivalenol (3-AcDON and 15-Ac-DON), and others (Bottalico \& Perrone, 2002). The trichothecene mycotoxins are potential inhibitors of protein biosynthesis. In mammals, they lead to unspecific effects in the intestines causing diarrhoea, vomiting, a reduced food intake and a raised bleeding tendency of the intestines. Their specific effects include a reduced 
leukocyte count connected with a loss of immune function and an increase in free radicals in the liver (Yabe et al., 1993, Tsuda et al., 1998, Thuvander et al., 1999, Eriksen \& Pettersson, 2004).

So far, little is known about naked barley [hull-less barley] (Hordeum vulgare nudum) cultivars, which are normally grown in organic farming systems, and the influence of Fusarium infection on the protein fractions in this cereal. The total protein content has been documented for naked barley as being between 12 and 16\% of dry mass (Bhatty, 1999). The influence of Fusarium infection on grain protein composition has been mainly investigated on wheat cultivars. The results of these studies have suggested that the infection degree had either no impact on the total protein content or it just caused a moderate increase in the total protein concentration (Boyacioglu \& Hettiarachchy, 1995, Wang et al., 2005). However, an influence on protein fractions, such as a rise in the prolamin (gliadins) and a reduction in the glutelin (glutenins) content, has been recorded. A change in the synthesis behaviour at different maturation stages has been postulated as an explanation for this observation (Wang et al., 2005). However, a study focusing on the synthesis of cereal seed storage proteins did not show any alterations in the synthesis stages during grain maturation; only a belated polymerization of glutenins was noted (Abonyi et al., 2007).

As stated above, barley storage proteins have been much less investigated in the context of Fusarium infection and the focus of this work was directed at determining the proteins that are expressed as a response to Fusarium infection (Geddes et al., 2008). Such proteins include pathogenesis-related proteins and defence-response proteins corresponding to the albumin and globulin fractions (Campo et al., 2004, Boddu et al., 2006, Piergiovanni, 2007, Geddes et al., 2008).

Increasing the nitrogen supply to wheat cultivars leads to an increase in their total protein content. The content of both prolamins and glutelin fractions are also increased. In contrast, no influence has been documented for the albumin and globulin fractions (Benetrix et al., 1994, Pechanek et al., 1997). Barley shows partly the same response to nitrogen with respect to its protein components as wheat (Shewry \& Halford, 2002, Wang et al., 2007). However, in contrast, the glutelins are not affected by nitrogen availability, while the albumin and globulin fraction increases (Wang et al., 2007). No studies have been done on naked barley so far.

The present study focuses on the influence of artificial Fusarium infection on the Osborne protein fractions in naked barley (Eggert et al., in press). Here the aim was to 
study the impact of Fusarium on the fractions of prolamins (hordeins) and glutelins (hordenins) and their different protein types in naturally and artificially infected samples. Our investigations were concentrated on harvested grains to determine the conditions in fully developed grains. Additionally, the effect of two different growing locations with respect to their nitrogen supply on the total protein content and quantitative protein composition was also monitored. Finally, the question as to which modifications in protein composition and protein synthesis occur in connection to nitrogen availability and exposition to Fusarium infection was addressed.

\section{Material and Methods}

Experimental design and sample preparation

Seven naked barley cultivars (Lawina, Linz, Frealishe, Yonas, ZFS, Taiga, 00/900/5N) and for comparison, one summer barley cultivar (Barke) were grown in two field trials at Reinshof (Ndong et al.) and Sattenhausen [SH] near Göttingen in the centre of Germany. The trials were randomized with eight replications. In each block, the second row was artificially inoculated during flowering three times with a mixed F. culmorum and F. graminearum spore suspension $\left(50 \mathrm{ml} / \mathrm{m}^{2} ; 1 \times 10^{5}\right.$ spores $\left./ \mathrm{ml}\right)$. Three DONproducing strains of F. culmorum (FC34, FC35, FC36) and F. graminearum (FG142; FG143; FG144) were used for conidiospore production. After harvest, the grain without inoculation (natural infection) and with inoculation (artificial infection) of the plots (each four replications) from each field trial were pooled. Whole grain flour was obtained by milling (Retsch ZM 100, Haan, Germany) at a particle size of $0.5 \mathrm{~mm}$.

The location conditions at RH are $152 \mathrm{~m}$ above sea level, wind sheltered and dale area near a river border. The $\mathrm{N}_{\min }$ content was $145 \mathrm{~kg} /$ ha recorded in $90 \mathrm{~cm}$ depth dry soil. At $\mathrm{SH}$, the conditions are $260 \mathrm{~m}$ above sea level, hilly and windy area. The $\mathrm{N}_{\text {min }}$ content was $95 \mathrm{~kg} / \mathrm{ha}$ in $90 \mathrm{~cm}$ depth dry soil and an additional fertilization with $40 \mathrm{~kg} \mathrm{~N} / \mathrm{ha}$ was conducted two months after sowing.

Quantitative LC-MS/MS of Fusarium mycotoxin DON and 3-Ac-DON

Whole grain flour $(5 \mathrm{~g})$ was extracted with $40 \mathrm{ml}$ of acetonitrile-water mixture (80:20) over night on a reciprocal shaker. The extracts were centrifuged for $12 \mathrm{~min}$ at 5,000 $\mathrm{g}$ and $4 \mathrm{ml}$ of the supernatant were used for solid-phase extraction (Bond-Elut Mycotoxin, Varian GmbH, Darmstadt, Germany) according to the manufacturer's instructions. Two millilitres of the cleaned extract were evaporated to dryness under vacuum, redissolved in $200 \mu \mathrm{l}$ of methanol-water (50:50) containing $0.2 \mathrm{mmol}$ ammonium acetate and ten 
microlitres of the solution were injected onto a C18 column (100 x $2 \mathrm{~mm}, 3 \mu \mathrm{m}$ particle size) filled with polar modified material (Polaris Ether, Varian GmbH, Darmstadt, Germany). The analytes were eluted with a methanol-water gradient (15\% to $70 \%$ methanol during $20 \mathrm{~min}$ ) containing $0.2 \mathrm{mmol}$ ammonium acetate at a flow rate of 0.2 $\mathrm{ml} / \mathrm{min}$. DON and 3-Ac-DON were detected by tandem mass spectrometry as described by Adejumo et al. (Adejumo et al., 2007).

\section{Quantitative nitrogen analysis}

The nitrogen content was quantitatively measured with a $\mathrm{C} / \mathrm{N}$-analyser (Vario MAX CN, Elementar Analysesysteme GmbH, Hanau, Germany). Each 100-mg dry sample was analysed for its $\mathrm{N}$ content and converted into protein with the factor 6.25 for barley. Quantitative protein analysis with RP-HPLC

Protein extraction from $100 \mathrm{mg}$ flour samples was realized stepwise. In the first step, 1 $\mathrm{ml}$ extraction with solution A (phosphate buffer containing 97 parts of $0.067 \mathrm{~mol} / \mathrm{l}$ Na2HPO4; $0.4 \mathrm{~mol} / 1 \mathrm{NaCl}$ and 3 parts $0.067 \mathrm{~mol} / 1 \mathrm{KH} 2 \mathrm{HPO} 4 ; 0.4 \mathrm{~mol} / 1 \mathrm{NaCl}$; $\mathrm{pH}$ 7.6) by vortexing for $2 \mathrm{~min}$ and shaking at room temperature (RT) for $10 \mathrm{~min}$ for albumins/globulins fractions, the extraction being repeated twice. The samples were centrifuged for $20 \mathrm{~min}$ at $6,000 \mathrm{x} \mathrm{g}$ and the supernatants were combined and filled up to $2 \mathrm{ml}$. The pellet was than extracted three times with $0.5 \mathrm{ml}$ extraction solution B [60\% ethanol (v/v)], vortexed for 2 min and exposed to 10 min shaking at RT. The samples were centrifuged for $20 \mathrm{~min}$ at $6,000 \mathrm{x} \mathrm{g}$ and the prolamin-containing supernatants were combined and filled up to $2 \mathrm{ml}$. In the third step, the remaining pellet was extracted two times with $1 \mathrm{ml}$ extraction solution C (50\% 1-Propanol (v/v) and 0.05 mol/1 Tris/HCl (pH 7.5) containing $2 \mathrm{~mol} / \mathrm{l}$ urea as well as $1 \%$ dithioerythritol) under $\mathrm{N}_{2}$, with $2 \mathrm{~min}$ vortexing and $30 \mathrm{~min}$ shaking at $60^{\circ} \mathrm{C}$. The samples were centrifuged for $20 \mathrm{~min}$ at $6,000 \mathrm{x} g$ and these glutelin-containing supernatants were combined and filled up to 2 ml. All extracts were filtered with $0.45 \mu \mathrm{m}$ Filter: FP 30/0.45 CA Whatman (schleicher + schnell) before HPLC injection.

For the RP-HPLC, a Nucleosil 300-5 C8 250 x 4.6 silica column (Macherey-Nagel, Dueren, Germany) was used. As mobile phases $\mathrm{A}=0.1 \%$ in $\mathrm{H}_{2} \mathrm{O}(\mathrm{v} / \mathrm{v})$ and $\mathrm{B}=0.1 \%$ TFA in acetonitrile $(\mathrm{v} / \mathrm{v})$ were applied. The flow rate was $1 \mathrm{ml} / \mathrm{min}$ with the column temperature maintained at $50^{\circ} \mathrm{C}$. For the albumins/globulins detection (Figure 1), $150 \mu \mathrm{l}$ of sample solution were injected and separated by using the following gradient: $0 \mathrm{~min}$, $20 \% \mathrm{~B} ; 20 \mathrm{~min}, 60 \% \mathrm{~B} ; 21 \mathrm{~min}, 90 \% \mathrm{~B}, 26 \mathrm{~min}, 90 \% \mathrm{~B} ; 37 \mathrm{~min} 20 \% \mathrm{~B}$; whereas for 
prolamins and glutelins (Figure 1), $50 \mu 1$ and $100 \mu 1$ were injected respectively and the separation was performed by applying the following gradient: $0 \mathrm{~min}, 24 \% \mathrm{~B} ; 50 \mathrm{~min}$, $56 \%$ B; $51 \min , 90 \%$ B, $56 \min , 90 \%$ B; $67 \min$ 24\% B (Wieser et al., 1998). The external PWG (Prolamin Working Group) gliadin standard was used for the quantification of the protein fractions (van Eckert et al., 2006).

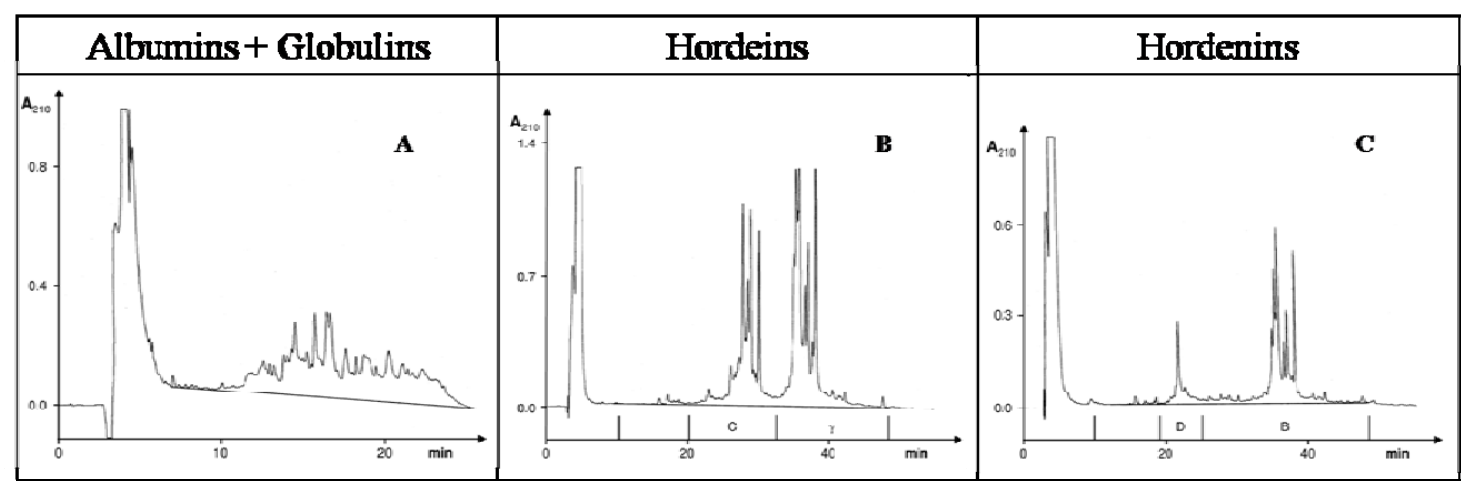

Figure 1 Protein fractions in naked barley [Lawina]: A: albumins + globulins total; B: C-hordeins; $\gamma$-hordeins; total hordeins (prolamins) from first to last bar; C: D-hordenins; B-hordenins, total hordenins (glutenins) from first to last line

Statistical analyses were performed using Microsoft Excel 2003 for mean value, standard deviation and significance $(p)$. For a more clear illustration of the results just the two of the naked barley cultivars with the strongest differences are presented separately in a table.

\section{Results and Discussion}

The influence of Fusarium infection on the toxin concentration and the quantitative protein composition of naked barley

Table 1 summarizes the results for the most different naked barley cultivars Frealishe (1a) and $00 / 900 / 5 \mathrm{~N}(1 \mathrm{~b})$, all seven naked barley cultivars on an average (1c), the summer barley cultivar Barke (1d), and a comparison of seven naked barley cultivars with summer barley cultivar Barke (1e). The detected fungal content expressed as Fusarium toxin (DON and 3-Ac-DON) in the naked barley and summer barley cultivars showed a significant increase in all the investigated parameters after artificial infection in comparison to the naturally infected cultivars (Tables 1a-e) except the cultivar $00 / 900 / 5 \mathrm{~N}$ in the location Sattenhausen. This confirms that the tested species and cultivars showed a certain susceptibility to Fusarium spp. depending on the degree of infection (Yang et al., 2008). Naked barley showed, in general, a higher content of Fusarium toxin than the investigated summer barley (Table 1e). In the seven naked 
barley cultivars, we found two with a higher degree of susceptibility (Lawina and Linz) and two with nearly the same susceptibility (Frealishe, Taiga) as summer barley cultivar.

Table 1a Protein concentration $\left(\mathrm{g} \mathrm{kg}^{-1}\right)$ in naturally and artificially Fusarium infected grain from the naked barley cultivar Frealishe and relative variance between the natural and artificial infections (\%) at the locations Sattenhausen and Reinshof, as well as the DON and 3-Ac-DON concentration of the natural and artificial infections

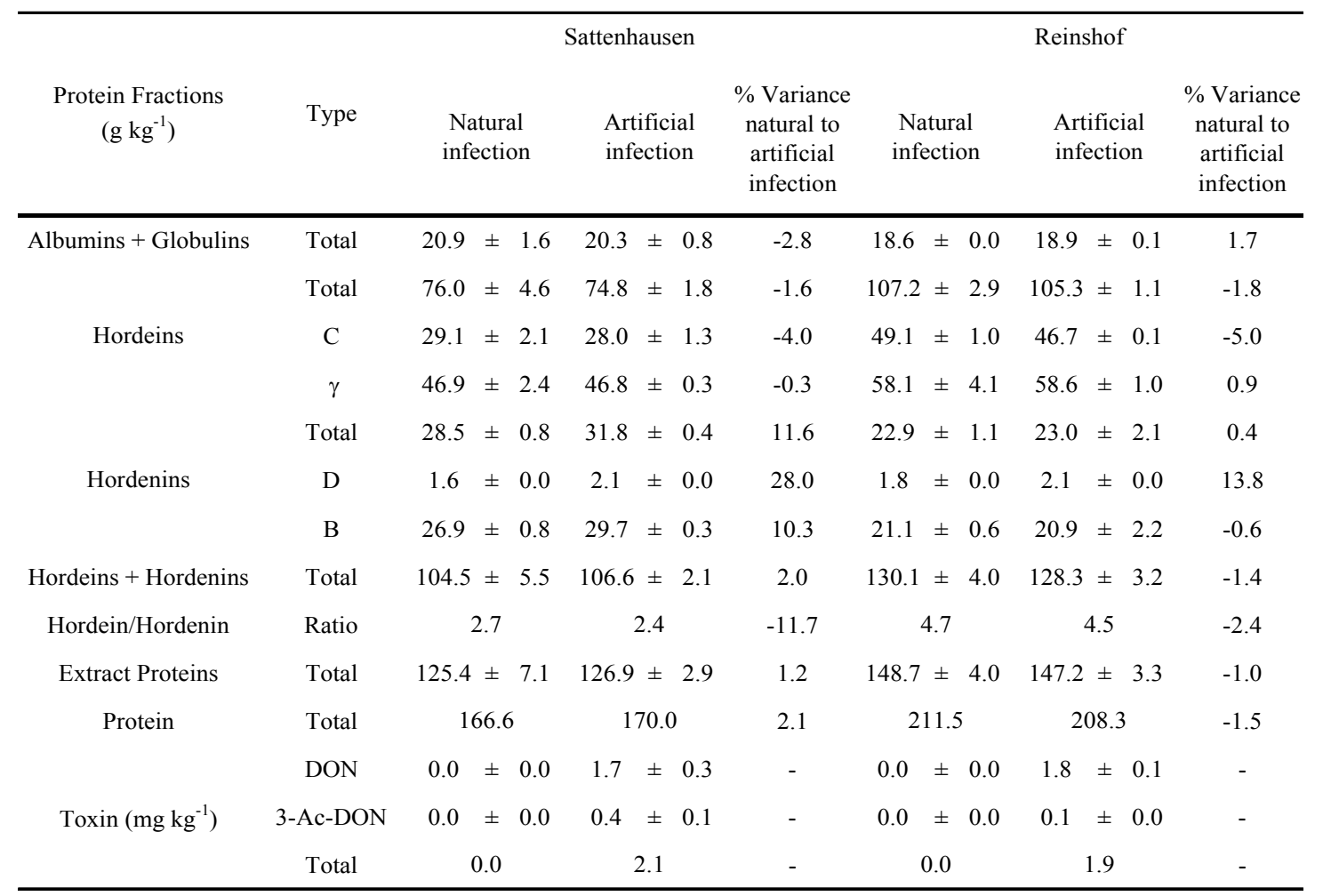


Table 1b Protein concentration $\left(\mathrm{g} \mathrm{kg}^{-1}\right)$ in naturally and artificially Fusarium infected grain from the naked barley cultivar $00 / 900 / 5 \mathrm{~N}$ and relative variance between the natural and artificial infections (\%) at the locations Sattenhausen and Reinshof, as well as the DON and 3-Ac-DON concentrations of the natural and artificial infections

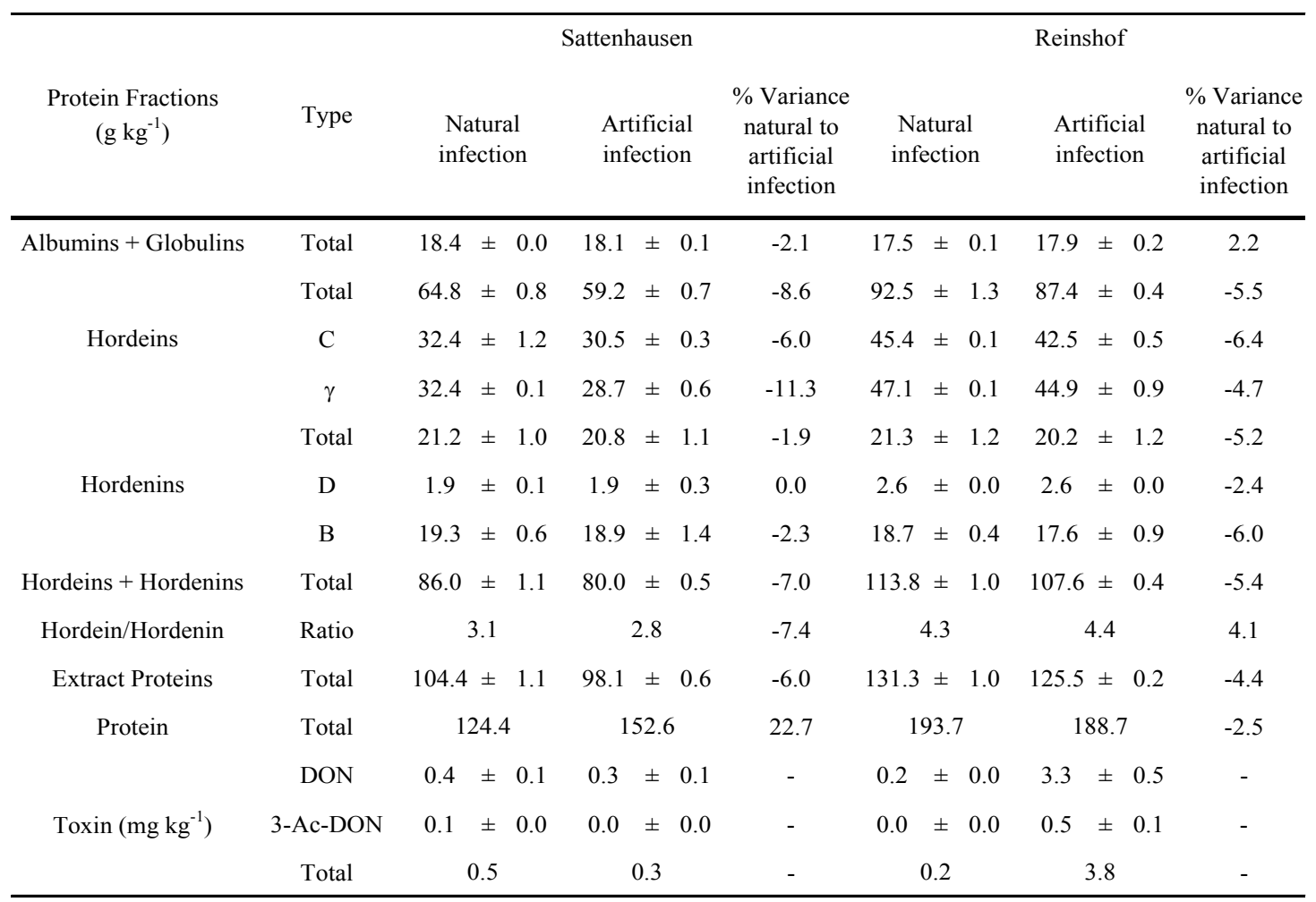


Table 1c Protein concentration $\left(\mathrm{g} \mathrm{kg}^{-1}\right)$ in naturally and artificially Fusarium infected grain from the seven naked barley cultivars $(n=7)$ and relative variance between the natural and artificial infections (\%) at the locations Sattenhausen and Reinshof, as well as the DON and 3-Ac-DON concentration of the natural and artificial infections

\begin{tabular}{|c|c|c|c|c|c|c|c|}
\hline & & & Sattenhausen & & & Reinshof & \\
\hline $\begin{array}{l}\text { Protein Fractions } \\
\qquad\left(\mathrm{g} \mathrm{kg}^{-1}\right)\end{array}$ & Type & $\begin{array}{c}\text { Natural } \\
\text { infection }\end{array}$ & $\begin{array}{l}\text { Artificial } \\
\text { infection }\end{array}$ & $\begin{array}{c}\% \text { Variance } \\
\text { natural to } \\
\text { artificial } \\
\text { infection }\end{array}$ & $\begin{array}{l}\text { Natural } \\
\text { infection }\end{array}$ & $\begin{array}{l}\text { Artificial } \\
\text { infection }\end{array}$ & $\begin{array}{c}\% \text { Variance } \\
\text { natural to } \\
\text { artificial } \\
\text { infection }\end{array}$ \\
\hline \multirow[t]{2}{*}{ Albumins + Globulins } & Total & $21.0 \pm 1.7$ & $21.2 \pm 2.1$ & 0.7 & $19.0 \pm 1.5$ & $19.3 \pm 1.4$ & 1.4 \\
\hline & Total & $66.9 \pm 13.6$ & $66.2 \pm 14.0$ & -1.0 & $90.8 \pm 12.3$ & $89.9 \pm 13.8$ & -1.0 \\
\hline \multirow[t]{3}{*}{ Hordeins } & $\mathrm{C}$ & $29.6 \pm 8.7$ & $29.5 \pm 8.9$ & -0.5 & $41.3 \pm 6.1$ & $41.1 \pm 6.9$ & -0.5 \\
\hline & $\gamma$ & $37.3 \pm 7.3$ & $36.7 \pm 7.8$ & -1.5 & $49.5 \pm 7.1$ & $48.8 \pm 8.0$ & -1.6 \\
\hline & Total & $22.9 \pm 4.7$ & $23.1 \pm 5.0$ & 0.9 & $22.2 \pm 4.6$ & $21.4 \pm 4.7$ & -3.6 \\
\hline \multirow[t]{2}{*}{ Hordenins } & $\mathrm{D}$ & $2.1 \pm 0.6$ & $2.2 \pm 0.7$ & 4.7 & $3.1 \pm 1.0$ & $2.9 \pm 0.7$ & -5.5 \\
\hline & B & $20.8 \pm 5.1$ & $20.9 \pm 5.4$ & 0.9 & $19.1 \pm 4.4$ & $18.5 \pm 4.6$ & -2.8 \\
\hline Hordeins + Hordenins & Total & $89.8 \pm 18.0$ & $89.3 \pm 18.2$ & -0.6 & $113.0 \pm 15.7$ & $111.3 \pm 17.9$ & -1.5 \\
\hline Hordein/Hordenin & Ratio & 2.9 & 2.9 & -2.0 & 4.0 & 4.2 & 4.2 \\
\hline Extract Proteins & Total & $110.8 \pm 18.5$ & $110.5 \pm 18.5$ & -0.3 & $132.0 \pm 15.1$ & $130.6 \pm 17.6$ & -1.1 \\
\hline \multirow[t]{2}{*}{ Protein } & Total & 155.8 & 163.9 & 5.2 & 195.9 & 196.3 & 0.2 \\
\hline & DON & $0.1 \pm 0.2$ & $2.0 \pm 2.0$ & - & $0.2 \pm 0.2$ & $2.7 \pm 1.1$ & - \\
\hline \multirow[t]{2}{*}{ Toxin $\left(\mathrm{mg} \mathrm{kg}^{-1}\right)$} & 3-Ac-DON & $0.0 \pm 0.0$ & $0.5 \pm 0.4$ & - & $0.0 \pm 0.1$ & $0.4 \pm 0.3$ & - \\
\hline & Total & 0.1 & 2.5 & - & 0.2 & 3.1 & - \\
\hline
\end{tabular}

The total and extractable protein content of the investigated naked barley cultivars did not changed significantly with respect to the Fusarium infection (Table 1e, Figure 2). These results are in agreement with another study in which no impact on total protein content in F. culmorum-infected wheat samples was also found (Wang et al., 2005). In contrast, older results from studies using F. graminearum showed a moderate increase in the total protein content related to the degree of infection (Boyacioglu \& Hettiarachchy, 1995).

Analyzing the difference between the total protein content and the extractable protein content showed that about $62-85 \%$ of the total protein content could be extracted by the method used in this investigation (Tables 1a-e). Non-extractable proteins are membrane-associated or those basic proteins with a high sugar content [26] and also include the non-extractable storage proteins. For a more complete and efficient extraction of the plant proteins, more specialised procedures must be used [27].

Comparing the naked barley cultivars with summer barley, we found $21 \%$ higher total and a $15 \%$ higher extractable protein content in the naked barley. However, the naked barley showed a high degree of variation of total protein for the seven investigated 
cultivars and the two growing regions of between 125 and $225 \mathrm{~g} \mathrm{~kg}^{-1}$ (Tables 1a-c). These values and high variation in the protein content of naked barley are supported by the literature (Bhatty, 1999), but the cause for the variations between the different cultivars is still unclear.

The influence of Fusarium infection on the Osborne fractions in naked barley and summer barley showed that the albumin and globulin fraction was not significantly changed. The naked barley contained $16 \%$ albumins/globulins, while there was a slightly higher content in summer barley of $19 \%$ (Table 1e).

Table 1d Protein concentration $\left(\mathrm{g} \mathrm{kg}^{-1}\right)$ in naturally and artificially Fusarium infected grain from the summer barley cultivar Barke and relative variance between the natural and artificial infections (\%) at the locations Sattenhausen and Reinshof, as well as the DON and 3-Ac-DON concentration of the natural and artificial infections

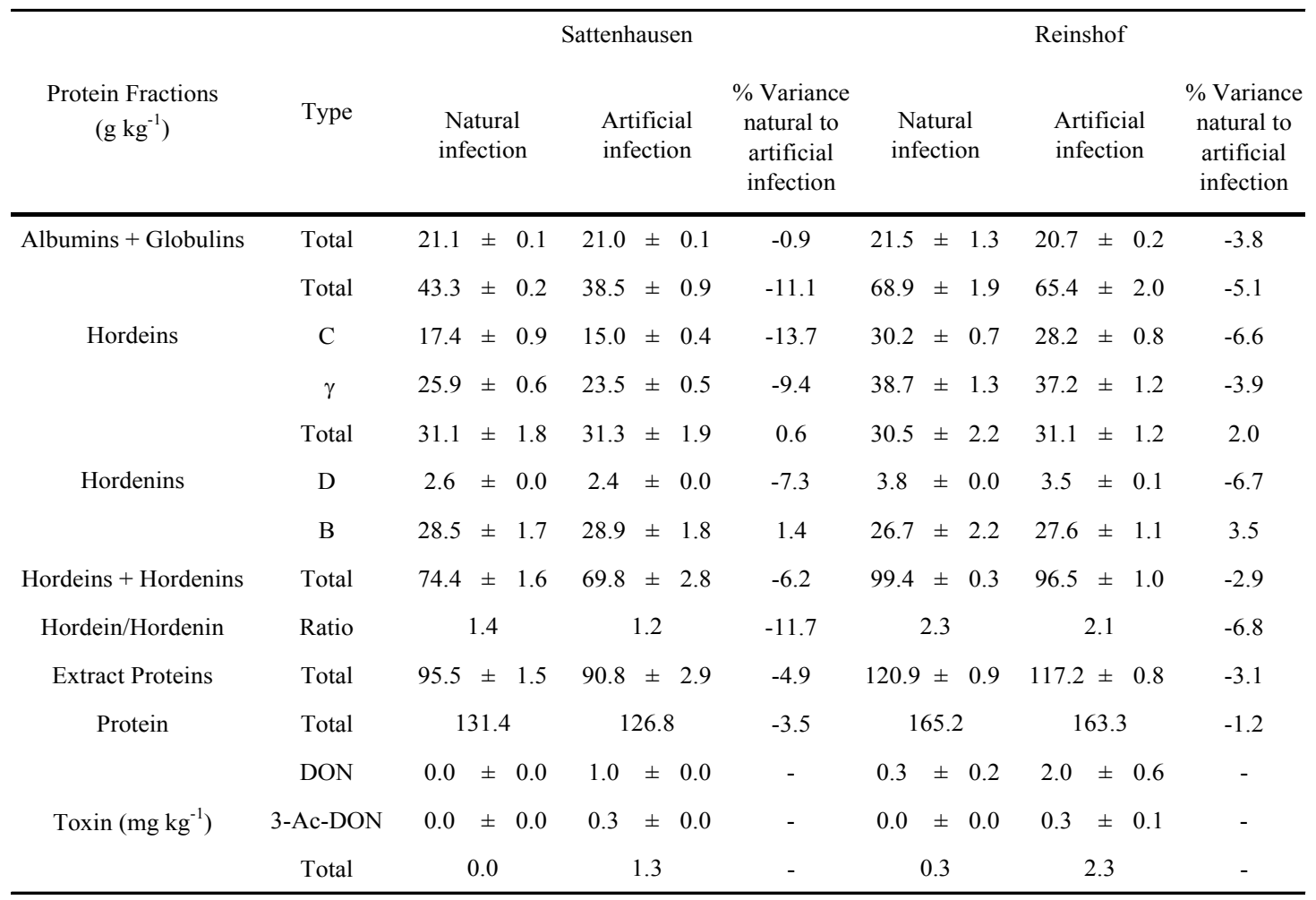


Table 1e Summary of protein concentration $\left(\mathrm{g} \mathrm{kg}^{-1}\right)$ in naturally and artificially Fusarium infected grain from the seven naked barley cultivars and the summer barley cultivar Barke with relative variance between the natural and artificial infections (\%) at both locations Sattenhausen and Reinshof, as well as the DON and 3-Ac-DON concentration of the natural and artificial infections

\begin{tabular}{|c|c|c|c|c|c|c|c|c|c|c|c|c|}
\hline \multirow[b]{3}{*}{$\begin{array}{l}\text { Protein Fractions } \\
\qquad(\mathrm{g} \mathrm{kg}-1)\end{array}$} & \multirow[b]{3}{*}{ Type } & \multicolumn{6}{|c|}{ Naked barley $(\mathrm{n}=7)$} & \multicolumn{5}{|c|}{ Barley $(\mathrm{n}=1)$} \\
\hline & & \multicolumn{6}{|c|}{ Sattenhausen + Reinshof } & \multicolumn{5}{|c|}{ Sattenhausen + Reinshof } \\
\hline & & \multicolumn{2}{|c|}{$\begin{array}{l}\text { Natural } \\
\text { infection }\end{array}$} & \multicolumn{2}{|c|}{$\begin{array}{l}\text { Artificial } \\
\text { infection }\end{array}$} & $\begin{array}{c}\% \text { Variance } \\
\text { natural to } \\
\text { artificial } \\
\text { infection }\end{array}$ & $\mathrm{p}^{\#}$ & \multicolumn{2}{|c|}{$\begin{array}{l}\text { Natural } \\
\text { infection }\end{array}$} & \multicolumn{2}{|c|}{$\begin{array}{l}\text { Artificial } \\
\text { infection }\end{array}$} & $\begin{array}{c}\% \text { Variance } \\
\text { natural to } \\
\text { artificial } \\
\text { infection }\end{array}$ \\
\hline Albumins + Globulins & Total & 20.0 & \pm 1.9 & 20.2 & \pm 2.0 & 1.0 & 0.3 & 21.3 & \pm 0.3 & 20.8 & \pm 0.2 & -2.4 \\
\hline & Total & 78.8 & \pm 17.5 & 78.0 & \pm 18.1 & -1.0 & 0.3 & 56.1 & \pm 18.2 & 51.9 & \pm 19.0 & -7.5 \\
\hline \multirow[t]{3}{*}{ Hordeins } & $\mathrm{C}$ & 35.4 & \pm 9.4 & 35.3 & \pm 9.7 & -0.5 & 0.6 & 23.8 & \pm 9.1 & 21.6 & \pm 9.4 & -9.2 \\
\hline & $\gamma$ & 43.4 & \pm 9.4 & 42.7 & \pm 9.8 & -1.5 & 0.1 & 32.3 & \pm 9.1 & 30.3 & \pm 9.7 & -6.1 \\
\hline & Total & 22.5 & \pm 4.5 & 22.3 & \pm 4.8 & -0.9 & 0.2 & 30.8 & \pm 0.5 & 31.3 & \pm 0.3 & 1.6 \\
\hline \multirow[t]{2}{*}{ Hordenins } & $\mathrm{D}$ & 2.6 & \pm 0.9 & 2.6 & \pm 0.8 & -1.3 & 0.5 & 3.2 & \pm 0.8 & 3.0 & \pm 0.8 & -6.9 \\
\hline & B & 19.9 & \pm 4.7 & 19.7 & \pm 5.0 & -0.9 & 0.5 & 27.6 & \pm 1.2 & 28.3 & \pm 0.9 & 2.4 \\
\hline Hordeins + Hordenins & Total & 101.3 & \pm 20.1 & 100.3 & \pm 20.7 & -1.0 & 0.1 & 86.9 & \pm 17.7 & 83.2 & \pm 18.7 & -4.3 \\
\hline Hordein/Hordenin & Ratio & & .5 & & .5 & 1.1 & - & 1.8 & & 1.7 & & -8.6 \\
\hline Extract Proteins & Total & 121.3 & 19.6 & 120.5 & 20.2 & -0.7 & 0.2 & 108.2 & \pm 18.0 & 104.0 & \pm 18.6 & -3.9 \\
\hline \multirow[t]{2}{*}{ Protein } & Total & & 5.8 & & 0.1 & 2.4 & 0.1 & 148.3 & & 145.0 & & -2.2 \\
\hline & DON & 0.2 & 0.2 & 2.4 & 1.3 & - & - & 0.3 & 0.2 & 1.5 & 0.7 & - \\
\hline \multirow[t]{2}{*}{ Toxin $\left(\mathrm{mg} \mathrm{kg}^{-1}\right)$} & 3-Ac-DON & 0.0 & 0.1 & 0.5 & 0.3 & - & - & 0.0 & 0.0 & 0.3 & 0.1 & - \\
\hline & Total & & .2 & & .9 & - & - & 0.3 & & 1.8 & & - \\
\hline
\end{tabular}

The prolamin (hordeins) and glutelin (hordenins) fractions and types were also not significant influenced by Fusarium infection (Table 1e). For hordeins, the artificially infected samples showed a slightly reduced concentration for all types in naked barley and summer barley in comparison to the naturally infected samples (Figure 2). The hordenins showed also a slight reduction in naked barley, but there was a slightly raised B-hordenin concentration in the summer barley (Figure 2). However, the ratio hordein/hordenin content either did not change or only to a minor degree.

For the present results, we assumed that these changes were due to a slight degradation of the barley proteins by the fungus as fungal proteases like trypsin protease or serine protease are part of the exoproteome of Fusarium spp. and they are known to be protein-degrading enzymes (Pekkarinen et al., 2000, Pekkarinen \& Jones, 2002, Phalip et al., 2005). The reasons for this lower degree of degradation of barley storage proteins in comparison to that found with wheat (Wang et al., 2005) may be (i) the localized 
infection which occurred only on selected single grains in barley (Jansen et al., 2005), or perhaps (ii) the occurrence of proteinase inhibition by microbial proteinase inhibitors such as barley Bowman-Birk inhibitor (BBI) or serine protease inhibitor (Pekkarinen \& Jones, 2003, Pekkarinen et al., 2007), or (iii) the synthesis of pathogenesis-related proteins (chitinase), defence-response proteins (oxidative burst response), proteinsynthesis-related proteins and proteins involved in the phenylpropanoid biosynthesis (phenole and indole derivates) pathway as a reaction to the Fusarium infection (Campo et al., 2004, Boddu et al., 2006, Piergiovanni, 2007, Geddes et al., 2008).

The hordein and hordenin fractions varied in content among the investigated naked barley cultivars both with respect to the location and cultivar: for hordeins between 54 and $109 \mathrm{~g} \mathrm{~kg}^{-1}$ and for hordenins between 17 and $32 \mathrm{~g} \mathrm{~kg}^{-1}$ (Tables 1a-c not all data shown). The investigated summer barley cultivar, Barke, also varied according to location (Table 1c): hordein between 39 and $70 \mathrm{~g} \mathrm{~kg}^{-1}$ and hordenins between 31 and 32 $\mathrm{g} \mathrm{kg}^{-1}$. The comparison between the naked barley and summer barley showed that the hordeins formed a bigger proportion of the extractable protein in naked barley $(65 \%)$ than in the summer barley (52\%) (Table 1e). In contrast, the proportion of the hordenin fraction was $9 \%$ higher in the summer barley than in the naked barley cultivars (Table 1e) apart from cvs. Linz and Frealishe which had proportions equivalent to those in the summer barley. These results led to a lower hordein/hordenin ratio for summer barley (1.2-2.3) in comparison to naked barley (2.4-5.2) (Tables 1a-1e). The reasons for these differences in the storage protein proportions between naked barley and summer barley may include a variation in the rate of synthesis in the developing kernels (Shewry \& Halford, 2002) although it is still unclear which factors cause these differences. 


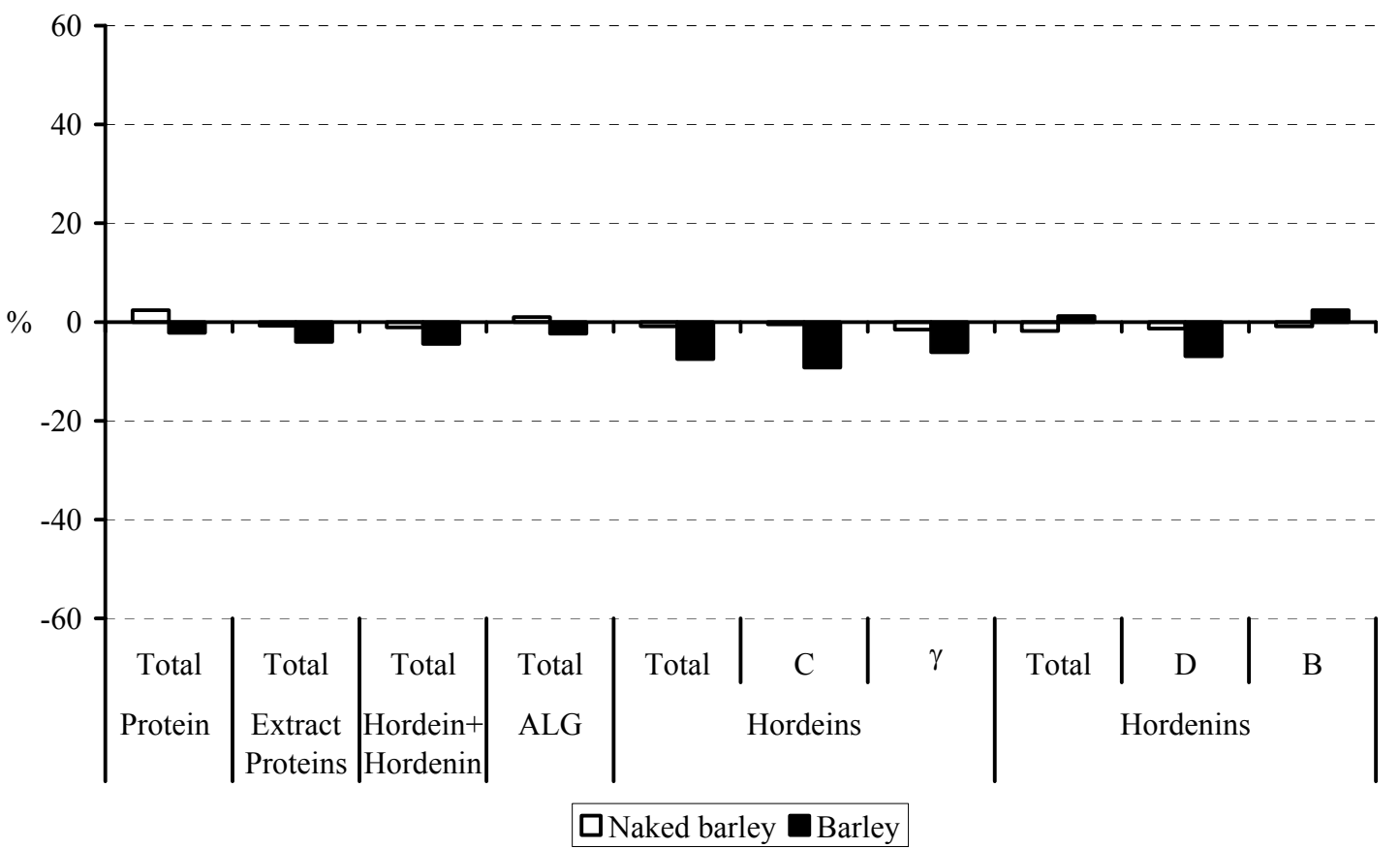

Figure 2 Variations in \% of protein fractions in naked barley $(n=7)$ and summer barley $(n=1)$ in whole grain flour from two growing locations after artificial Fusarium infection in comparison to natural infection, $\mathrm{ALG}=$ albumins + globulins

Effect of $N$ supply at two different growing locations on the quantitative protein composition

For both naked barley and summer barley, the total protein content seemed to be significantly connected to the conditions present at the growing location (Tables 1a-e; Figure 3). For the impact of the location on the extracted protein fractions in naked barley and summer barley, we considered both the naturally and artificially fungal infected samples together. The naked barley showed a significant $23 \%$ higher total protein content and a significant $18 \%$ higher extractable protein content at $\mathrm{RH}$ (higher $\mathrm{N}$ supply) in comparison to SH (Table 2; Figure 3). The summer barley data support this change based on the $\mathrm{N}$ supply of the location (Table 2; Figure 3). 
Table 2 Variance of relative protein concentration between the two locations, Sattenhausen and Reinshof, of seven naked barley cultivars and the summer barley cultivar Barke with respect to the $\mathrm{N}$ supply

\begin{tabular}{cccc}
\hline Protein Fractions & Type & $\begin{array}{c}\text { Naked Barley } \\
(\mathrm{n}=7)\end{array}$ & $\begin{array}{c}\text { Barley } \\
(\mathrm{n}=1)\end{array}$ \\
\hline Albumins + Globulins & Total & -9.2 & 0.2 \\
& Total & 34.7 & 62.9 \\
Hordeins & C & 39.4 & 80.7 \\
& $\gamma$ & 32.8 & 53.9 \\
Hordenins & Total & -5.2 & -1.7 \\
& D & 35.8 & 43.2 \\
Hordeins + Hordenins & B & -9.8 & -5.2 \\
Extract Proteins & Total & 24.4 & 35.1 \\
Protein & Total & 18.1 & 27.4 \\
\hline
\end{tabular}

A significant $9 \%$ reduction in the albumins and globulins was observed in naked barley at $\mathrm{RH}$ in comparison to $\mathrm{SH}$ (Fig. 4). This reduction in the albumin and globulin fraction could not be confirmed in the summer barley results as a minor increase in this fraction occurred (Table 2). These results are not supported by $\mathrm{N}$ supply studies on wheat as no changes in the albumin and globulin fraction were detected in this cereal (Pechanek et al., 1997, Johansson et al., 2001). The reasons for this reduction in association with $\mathrm{N}$ supply in naked barley are unclear but there may be a suppression of albumin and globulin synthesis at locations with a high $\mathrm{N}$ supply in contrast to the induced storage protein synthesis found in naked barley under these conditions (Table 2) (Benetrix et al., 1994, Pechanek et al., 1997, Wang et al., 2007).

The hordein content was significantly increased by $35 \%$ in naked barley and by $63 \%$ in summer barley at RH compared to SH (Figure 4, 5). The C-hordeins were the most affected proteins in both types of barley (Figure 5; Table 2). It can be, therefore, be postulated that summer barley is more susceptible to a raised $\mathrm{N}$ supply with respect to hordeins than naked barley. In contrast, the total amount of hordenins was negatively influenced (Table 2; Figure. 4, 5). At RH, the naked barley showed a reduction of 5\% (significant for B- and D-hordenins) and the summer barley a minus of $1 \%$ in 
comparison to $\mathrm{SH}$ (Figure 5). Looking at the hordenin fractions individually, only the D-hordenins showed a higher content (Table 2). The B-hordenins were found in significantly lower concentrations in comparison to the other fractions (Figure 4, 5). This reduction of B-hordenins was observed in all the investigated naked barley and summer barley cultivars (Tables 1a-e) and is supported by literature results where it is suggested that $\mathrm{N}$ has an influence on hordeins (Wang et al., 2007). In conclusion, in this study, the C-hordeins, $\gamma$-hordeins and D-hordenins increased in content, while the Bhordenins decreased.

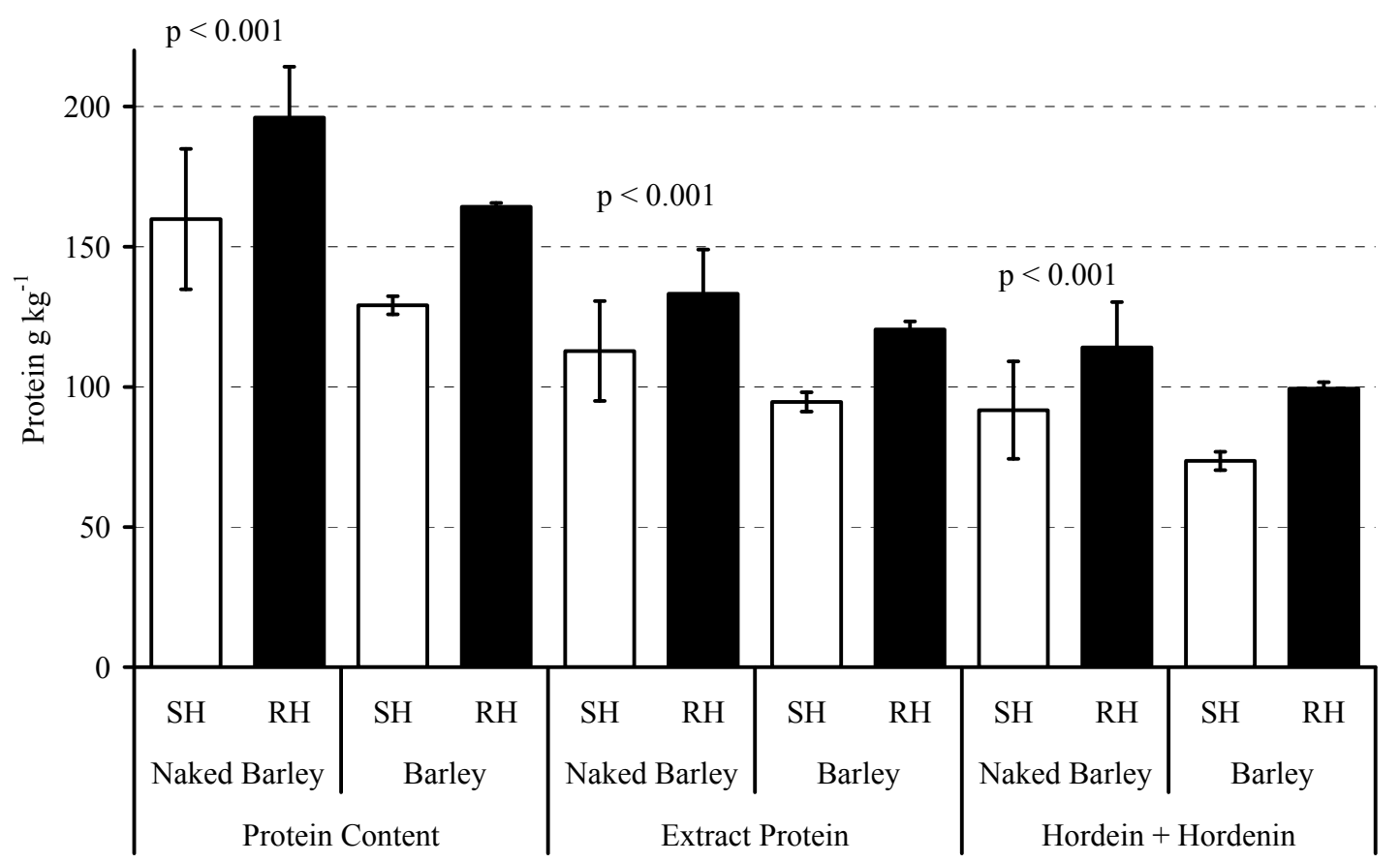

Figure 3 Protein content in grains of naked barley $(n=7)$ and summer barley $(n=1)$ at two locations (SH: Sattenhausen; RH: Reinshof) with different N supplies; significant changes for naked barley are denoted as p-values 


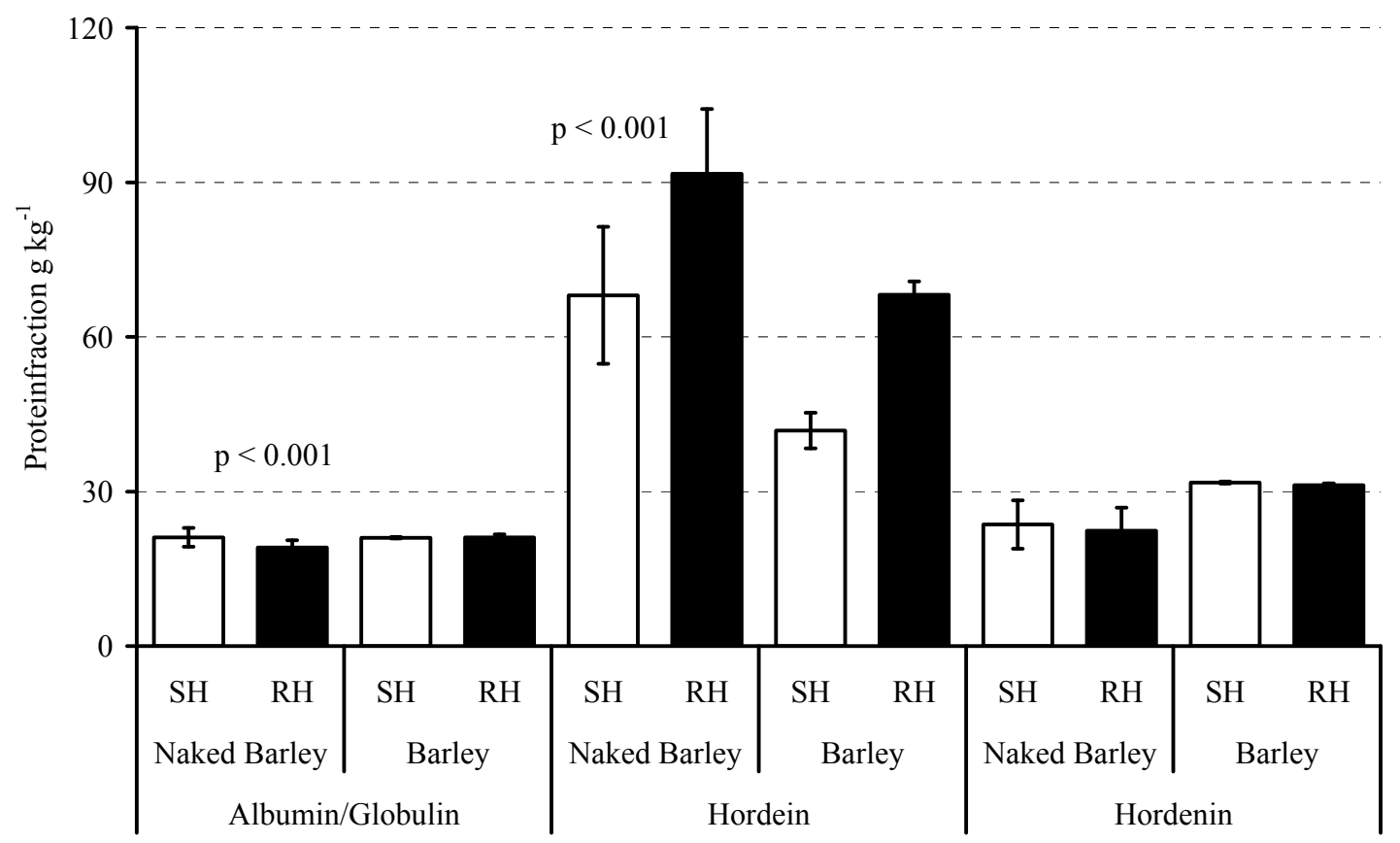

Figure 4 Quantities of albumins/globulins, hordein (prolamins) and hordenin (glutelins) protein fractions in naked barley $(n=7)$ and summer barley $(n=1)$ at two locations (SH: Sattenhausen; RH: Reinshof) in grain with different N supplies; significant changes for naked barley are denoted as p-values

So far little is known about barley protein types. The present results show that Bhordenins synthesis is not connected to the total protein content and the synthesis of the other protein types (Figure 4, 5). The reason for this irregular synthesis of barley storage protein types is possibly due to the regulation of synthesis. Nitrogen availability and the resulting higher total protein content has been documented as being a factor that can promote gene expression (Shewry \& Halford, 2002). These upstream factors have been identified as separate motifs $\mathrm{E}$ and $\mathrm{N}$ in $\mathrm{C}$-hordeins and at adequate nitrogen levels these motifs enhanced gene expression and decrease it at low nitrogen levels (Shewry \& Halford, 2002). Such gene promoters are known also from other cereals, like wheat or maize, where the base sequence changed in length and in its base sequence, or a motif was found to be missing. This could explain why B-hordenins were not enhanced in comparison to the other three barley protein fractions as it is likely that the promoter motifs are missing, so that the protein synthesis cannot be enhanced. An influence of the amino acid composition or synthesis can be excluded because no characteristic features in amino acid composition were found to be apparent for B-hordenins in comparison to the other types (Lange et al., 2007). 


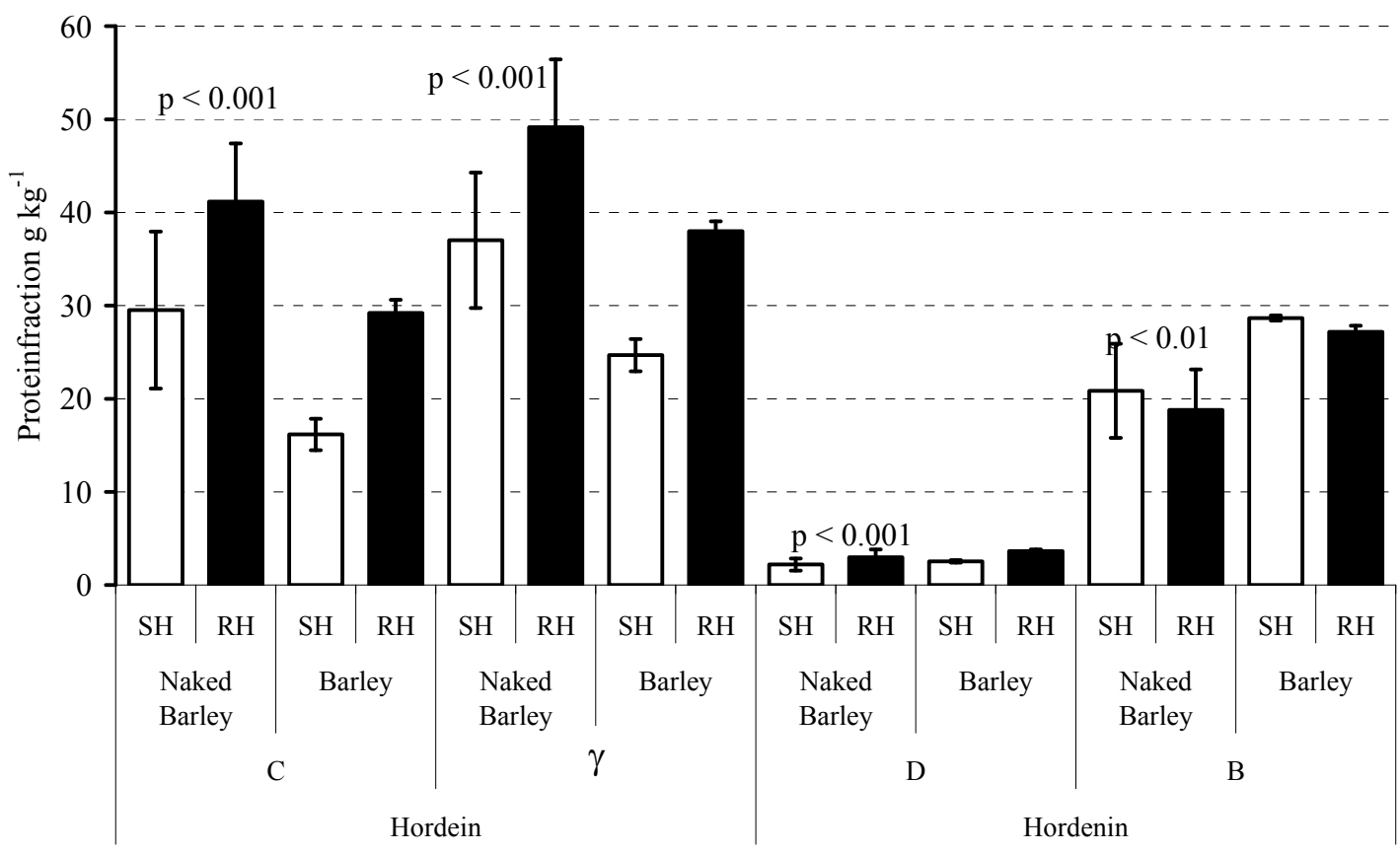

Figure 5 Quantities of hordein and hordenin fractions in naked barley $(n=7)$ and summer barley $(\mathrm{n}=1)$ at two locations (SH: Sattenhausen; RH: Reinshof) in grain with different $\mathrm{N}$ supplies; significant changes for naked barley are denoted as $\mathrm{p}$-values

\section{Conclusions}

Naked barley, normally grown under organic farming conditions, and summer barley showed no characteristic changes in protein composition as a reaction to Fusarium spp. infection. This is in contrast to wheat, where such changes are known to occur. In addition to these basic findings, new information about the degradation and changes in different protein types was attained. As a consequence, further investigations focussed in general on protein degradation are recommended. The influence of the growing location and nitrogen availability on the protein content has been documented in previous studies on wheat and barley. The present results support and enlarge these findings for naked barley as the naked barley showed characteristic changes in the synthesis of its protein types in response to increased nitrogen. Further studies in this context may help to clarify the mechanisms that lead to the irregular synthesis of barley protein subunits depending on nitrogen availability.

\section{Abbreviations used}

ALG, albumins/globulins; DM, dry matter; LC-MS/MS, liquid chromatography with coupled mass spectrometry; $p$, significance factor; RP-HPLC, reversed-phase highperformance liquid chromatography; RT, room temperature; TFA, trifluoroacetic acid. 


\section{Acknowledgements}

This work is part of the FAEN Joint Project 3 "Quality-related plant production under modified basic conditions: mycotoxins in the context of production, quality and processing", financed by the Ministry of Science and Culture of Lower Saxony, Germany. Special thanks are given to the grower Eckard Irion, Verein für Pflanzenzucht, Hof Grub e.V., who provided the seeds for this research trial as well as to the group of Prof. Petr Karlovsky, and especially to Sasithorn Limsuwan, Molecular Phytopathology and Mycotoxin Research, Department of Crop Science, Georg-August University Goettingen for the toxin analysis.

\section{References}

Abonyi, T., Kiraly, I., Tomoskozi, S., Baticz, O., Guoth, A., Gergely, S., Scholz, E., Lasztity, D.Lasztity, R. 2007. Synthesis of gluten-forming polypeptides. 1. Biosynthesis of gliadins and glutenin subunits. Journal of Agricultural and Food Chemistry 55: 3655-3660

Adejumo, T. O., Hettwer, U.Karlovsky, P. 2007. Occurrence of fusarium species and trichothecenes in nigerian maize. International Journal of Food Microbiology 116: 350-357

Benetrix, F., Sarrafi, A.Autran, J. C. 1994. Effects of genotype and nitrogen nutrition on protein aggregates in barley. Cereal Chemistry 71: 75-82

Bhatty, R. S. 1999. The potential of hull-less barley. Cereal Chemistry 76: 589-599

Boddu, J., Cho, S., Kruger, W. M.Muehlbauer, G. J. 2006. Transcriptome analysis of the barleyfusarium graminearum interaction. Molecular Plant-Microbe Interactions 19: 407-417

Bottalico, A.Perrone, G. 2002. Toxigenic fusarium species and mycotoxins associated with head blight in small-grain cereals in europe. European Journal of Plant Pathology 108: 611-624

Boyacioglu, D.Hettiarachchy, N. S. 1995. Changes in some biochemical-components of wheatgrain that was infected with fusarium-graminearum. Journal of Cereal Science 21: 57-62

Buerstmayr, H., Stierschneider, M., Steiner, B., Lemmens, M., Griesser, M., Nevo, E.Fahima, T. 2003. Variation for resistance to head blight caused by fusarium graminearum in wild emmer (triticum dicoccoides) originating from israel. Euphytica 130: 17-23

Campo, S., Carrascal, M., Coca, M., Abian, J.San Segundo, B. 2004. The defense response of germinating maize embryos against fungal infection: A proteomics approach. Proteomics 4: 383-396

Eggert, K., Wieser, H.Pawelzik, E. in press. The influence of fusarium infection and growing location on protein fractions in emmer (triticum dicoccum). Journal of Agricultural and Food Chemistry

Eriksen, G. S.Pettersson, H. 2004. Toxicological evaluation of trichothecenes in animal feed. Animal Feed Science and Technology 114: 205-239

Geddes, J., Eudes, F., Laroche, A.Selinger, L. B. 2008. Differential expression of proteins in response to the interaction between the pathogen fusarium graminearum and its host, hordeum vulgare. Proteomics 8: 545-554

Jansen, C., von Wettstein, D., Schafer, W., Kogel, K. H., Felk, A.Maier, F. J. 2005. Infection patterns in barley and wheat spikes inoculated with wild-type and trichodiene synthase gene disrupted fusarium graminearum. Proceedings of the National Academy of Sciences of the United States of America 102: 16892-16897

Johansson, E., Prieto-Linde, M. L.Jonsson, J. O. 2001. Effects of wheat cultivar and nitrogen application on storage protein composition and breadmaking quality. Cereal Chemistry 78: 19- 
Lange, M., Vincze, E., Wieser, H., Schjoerring, J. K.Holm, P. B. 2007. Suppression of chordein synthesis in barley by antisense constructs results in a more balanced amino acid composition. Journal of Agricultural and Food Chemistry 55: 6074-6081

Ndong, C., Danyluk, Jean, Wilson, Kenneth E., Pocock, Tessa, Huner, Norman P. A.Sarhan, F. 2002. Cold-regulated cereal chloroplast late embryogenesis abundant-like proteins. Molecular characterization and functional analyses. Plant Physiol 129: 1368-81

Pechanek, U., Karger, A., Groger, S., Charvat, B., Schoggl, G.Lelley, T. 1997. Effect of nitrogen fertilization on quantity of flour protein components, dough properties, and breadmaking quality of wheat. Cereal Chemistry 74: 800-805

Pekkarinen, A. I.Jones, B. L. 2003. Purification and identification of barley (hordeum vulgare 1.) proteins that inhibit the alkaline serine proteinases of fusarium culmorum. Journal of Agricultural and Food Chemistry 51: 1710-1717

Pekkarinen, A. I.Jones, B. L. 2002. Trypsin-like proteinase produced by fusarium culmorum grown on grain proteins. Journal of Agricultural and Food Chemistry 50: 3849-3855

Pekkarinen, A. I., Longstaff, C.Jones, B. L. 2007. Kinetics of the inhibition of fusarium serine proteinases by barley (hordeum vulgare 1.) inhibitors. Journal of Agricultural and Food Chemistry 55: 2736-2742

Pekkarinen, A., Mannonen, L., Jones, B. L.Niku-Paavola, M. L. 2000. Production of proteases by fusarium species grown on barley grains and in media containing cereal proteins. Journal of Cereal Science 31: 253-261

Phalip, V., Delalande, F., Carapito, C., Goubet, F., Hatsch, D., Leize-Wagner, E., Dupree, P., Van Dorsselaer, A.Jeltsch, J. M. 2005. Diversity of the exoproteome of fusarium graminearum grown on plant cell wall. Current Genetics 48: 366-379

Piergiovanni, A. R. 2007. Extraction and separation of water-soluble proteins from different wheat species by acidic capillary electrophoresis. Journal of Agricultural and Food Chemistry 55: 3850-3856

Ramirez, M. L., Reynoso, M. M., Farnochi, M. C.Chulze, S. 2006. Vegetative compatibility and mycotoxin chemotypes among fusarium graminearum (gibberella zeae) isolates from wheat in argentina. European Journal of Plant Pathology 115: 139-148

Shewry, P. R.Halford, N. G. 2002. Cereal seed storage proteins: Structures, properties and role in grain utilization. Journal of Experimental Botany 53: 947-958

Thuvander, A., Wikman, C.Gadhasson, I. 1999. In vitro exposure of human lymphocytes to trichothecenes: Individual variation in sensitivity and effects of combined exposure on lymphocyte function. Food and Chemical Toxicology 37: 639-648

Tsuda, S., Kosaka, Y., Murakami, M., Matsuo, H., Matsusaka, N., Taniguchi, K.Sasaki, Y. F. 1998. Detection of nivalenol genotoxicity in cultured cells and multiple mouse organs by the alkaline single-cell gel electrophoresis assay. Mutation Research-Genetic Toxicology and Environmental Mutagenesis 415: 191-200

van Eckert, R., Berghofer, E., Ciclitira, P. J., Chirdo, F., Denery-Papini, S., Ellis, H. J., Ferranti, P., Goodwin, P., Immer, U., Mamone, G., et al. 2006. Towards a new gliadin reference material-isolation and characterisation. Journal of Cereal Science 43: 331-341

Wang, J. H., Wieser, H., Pawelzik, E., Weinert, J., Keutgen, A. J.Wolf, G. A. 2005. Impact of the fungal protease produced by fusarium culmorum on the protein quality and breadmaking properties of winter wheat. European Food Research and Technology 220: 552-559

Wang, J. M., Chen, J. X., Dai, F., Wu, F. B., Yang, J. M.Zhang, G. P. 2007. Protein fractions in barley grains as affected by some agronomic factors and their relationships to malt quality. CEREAL RESEARCH COMMUNICATIONS 35: 129-140

Wieser, H., Antes, S.Seilmeier, W. 1998. Quantitative determination of gluten protein types in wheat flour by reversed-phase high-performance liquid chromatography. Cereal Chemistry 75: 644-650 
Yabe, T., Hashimoto, H., Sekijima, M., Degawa, M., Hashimoto, Y., Tashiro, F.Ueno, Y. 1993. Effects of nivalenol on hepatic drug-metabolizing activity in rats. Food and Chemical Toxicology 31: 573-581

Yang, L., van der Lee, T., Yang, X., Yu, D.Waalwijk, C. 2008. Fusarium populations on chinese barley show a dramatic gradient in mycotoxin profiles. Phytopathology 98: 719-72 



\title{
5.5 In vitro-degradation of wheat gluten fractions by Fusarium graminearum proteases
}

\begin{abstract}
Fusarium spp. infection of grain cereals is a common problem, which leads to a dramatic loss of grain quality. The presented study focused on the effect of Fusarium infection on the wheat storage protein gluten and its fractions, the gliadins and glutenins, in a model system. The fractions were separated by different extraction procedures and characterized by chromatographic (RP-HPLC) and electrophoresis analysis (SDS-Page). The effect of Fusarium graminearum proteases on wheat storage proteins was studied in vitro. Gluten digestion by these proteases showed a preference for the glutenin fraction in comparison to the gliadin fraction. The HMW-GS were the most affected glutenin fractions. These are known to contain a higher lysine content than the LMW-GS. Separate digestion of the isolated gliadin and glutenin fractions underlined the preference for HMW-GS. The digestion additionally affected the yield and composition of the proteins extracted according to the traditional solvent procedure. Glutenin fragments were found in the gliadin extraction solution after digestion. This observation explains the frequently reported reduced glutenin quantities with an increase in gliadin quantity after Fusarium infection in grains.
\end{abstract}

Keywords: peptides, serine and trypsin protease; $\mathrm{C} / \mathrm{N}-$ ratio; celiac disease; toxins Introduction

Fusarium graminearum (teleomorph: Gibberella zeae) is the most relevant species in Europe for Fusarium head blight, infecting grains like wheat, maize and barley (Foroud and Eudes, 2009; Parry et al., 1995). Besides this species, F. culmorum, and a number of other Fusarium spp. are known to also induce Fusarium head blight (Parry et al., 1995; Yazar and Omurtag, 2008). Fusarium graminearum produces trichothecene mycotoxins such as nivalenol (NIV) and deoxynivalenol (DON) (Bottalico Antonio, 2002). High concentrations of Fusarium toxins in the diet lead to adverse effects on human and animal health. Typical symptoms are vomiting, diarrhoea, internal bleeding of the intestines at high doses with an impairment of the immune function and the inhibition of protein synthesis (Eriksen and Pettersson, 2004; Nielsen et al., 2009; Thuvander et al., 1999). These toxic effects make the reduction of trichothecene content in food and feed essential; therefore, the European Union has limited the maximum amounts of DON allowed in products destined for human food [Commission Regulation 
(EC) No. 856/2005. 2006] and for animal nutrition [Commission Regulation (EC) No. 576/2006. 2006].

In moderately temperate countries, wheat is used as a predominant crop for food products based on the viscoelastic properties of its main protein fractions, summarized as gluten (Shewry, 2009). These fractions play an important role for the characteristics of the baking quality of dough (Anjum et al., 2007; Nightingale et al., 1999). For testing wheat baking quality, characterisation of the gluten proteins must be differentiated into typical fractions by applying solvent extraction. The most popular process here is a modified procedure based on the method of Osborne (Wieser, 2000). The separation of the proteins results in an albumin/globulin fraction and the gluten storage proteins the gliadins ( $\omega$-, $\alpha$ - and $\gamma$-gliadins) and the glutenins [ $\omega$-glutenin, high-molecularweight glutenin (HMW-GS) and low-molecular-weight glutenin (LMW-GS) subunits].

Fusarium infection and protease production can lead by causing gluten destruction to decreased dough consistence and resistance to extension, which results in loss of dough functionality and loaf volume (Nightingale et al., 1999). Recent studies about the influence of Fusarium infection on grain protein composition have documented either no or just a moderate impact on total protein content and suggested that this depended on the infection degree (Boyacioglu and Hettiarachchy, 1995; Wang et al., 2005). However, an influence on the distribution and composition of the protein fractions, such as an increase in gliadin and a reduction in glutenin content has also been recorded (Eggert et al., in press; Wang et al., 2005). Fungal proteases include trypsin- or serinelike proteases. These are also part of the exoproteome of Fusarium spp. and are known to degrade proteins in both wheat and barley grains (Pekkarinen et al., 2000; Pekkarinen and Jones, 2002; Phalip et al., 2005). The earlier reported reduction of the glutenin fractions and an increase in the quantity of the gliadin fraction due to such proteases cannot be explained by any change in the synthesis behaviour at the different maturation stages as has been postulated as an explanation for this observation (Wang et al., 2005) because studies focusing on the synthesis of cereal seed storage proteins did not show any alterations in the synthesis behaviour during grain maturation and only a belated polymerization of glutenins was noted (Abonyi et al., 2007). Therefore, other effects resulting in the degradation of the gluten fractions as detected and quantified by RPHPLC could occur.

The present study should contribute to the clarification of the storage protein degradation by F. graminearum proteases in a model system. This experiment could 
possibly explain the reduced baking quality of Fusarium-infected grains. Furthermore, Fusarium protease preference for individual gluten fractions may be shown. Additionally, the experiment design focused on the characterisation of the separated fractions originating after protease action by RP-HPLC for quantification and by SDSPage for specification of the molecular weights of the liberated products.

\section{Materials and Methods}

\section{Protein extraction procedure}

For extraction of the gluten as well as the gluten fractions, gliadin and glutenin, commercially available gluten from wheat (Sigma-Aldrich Chemie GmbH, Steinheim, Germany) was used. In the first cleaning step, gluten was washed twice with a fivefold quantity of an albumin and globulin extracting solution $\mathrm{A}\left[\mathrm{HKNaPO}_{4}: 97\right.$ parts $\mathrm{Na}_{2} \mathrm{HPO}_{4}(0.067 \mathrm{~mol} / \mathrm{l})+(0.4 \mathrm{~mol} / \mathrm{l}) \mathrm{NaCl}$ and 3 parts $\mathrm{KH}_{2} \mathrm{HPO}_{4}(0.067 \mathrm{~mol} / \mathrm{l})+(0.4$ $\mathrm{mol} / \mathrm{l}) \mathrm{NaCl}$; $\mathrm{pH} 7.6$ ] for $30 \mathrm{~min}$ by shaking at room temperature to remove any leftover contamination of these fractions. In each extraction cycle, the sample was centrifuged for $20 \mathrm{~min}$ at $4000 \mathrm{rpm}$ (x $1702 \mathrm{~g}$ ) and the supernatant was discarded. The pellet was than washed for 30 min with dest. $\mathrm{H}_{2} \mathrm{O}$ to remove salt residues and centrifuged for 20 min at $4000 \mathrm{rpm}$ (x $1702 \mathrm{~g})$; the supernatant was again discarded.

Gliadin extraction was realised by extracting three times with a fivefold quantity of the extraction solution B containing $60 \%$ ethanol (v/v) by homogenisation of the pellet for 1 $\min$ at $24000 \mathrm{rpm}$ with an ultra turrax $\left(\mathrm{IKA}^{\circledR}\right.$ Werke $\mathrm{GmbH}$ \&Co.KG, Staufen, Germany) and shaking for $30 \mathrm{~min}$. Each cycle was concluded by a centrifugation step at $7000 \mathrm{rpm}(\mathrm{x} 1702 \mathrm{~g}$ ) for $20 \mathrm{~min}$ at room temperature. The gliadin-containing supernatants were combined and filtered (MN 616 1⁄4 $\varnothing 150$ mm; MACHERY-NAGEL GmbH \& Co. KG, Düren, Germany). The main part of the ethanol was evaporated at $40^{\circ} \mathrm{C}$ for $24 \mathrm{~h}$ and the residue was freeze-dried (CHRIST Gefriertrocknungsanlagen, EPSILON 2-40, Osterode, Germany), homogenised by pestle under liquid nitrogen $\left(\mathrm{N}_{2}\right)$ and stored at $-20^{\circ} \mathrm{C}$.

Glutenin extraction was realised by extracting twice with a fivefold quantity of the extraction solution C [containing 50\% 1-propanol (v/v) mixed with $50 \%$ of $2 \mathrm{~mol} / 1$ urea, $0.05 \mathrm{~mol} / \mathrm{l}$ Tris/ $\mathrm{HCl}(\mathrm{pH} 7.5)$ and 1\% dithioerythritol - (DTE)] by homogenisation of the pellet under $\mathrm{N}_{2}$ for $1 \mathrm{~min}$ at $24000 \mathrm{rpm}$ with an ultra turrax in each cycle, followed by $30 \mathrm{~min}$ shaking at $60^{\circ} \mathrm{C}$ and centrifugation for $20 \mathrm{~min}$ at $7000 \mathrm{rpm}$ (x $5214 \mathrm{~g}$ ) at room temperature. The glutenin-containing supernatants were combined, filtered and dialysed for $24 \mathrm{~h}$ in a cellulose acetate tube against distilled water. The residue was 
freeze-dried, homogenised by pestle under liquid $\mathrm{N}_{2}$ and washed again three times with extraction solution B to remove any gliadin residue. The pellet was finally washed with ice-cold $\left(-20^{\circ} \mathrm{C}\right)$ acetone, dried under $\mathrm{N}_{2}$ and stored at $-20^{\circ} \mathrm{C}$. This extraction procedure was adapted with modifications from the method of Wieser et al. (Wieser et al., 1998).

\section{Preparation of Fusarium graminearum protease solution}

The isolation of F. graminearum protease extract and the further experimental design is illustrated in Figure 1. Wheat seeds (cultivar: mix of Ritmo and Centrum) were milled (Retsch ZM 100, Haan, Germany) to a crude particle size lower than $0.5 \mathrm{~mm} .5 \mathrm{~g}$ of the milled seeds were filled in a 250-ml Erlenmeyer flask and mixed with $30 \mathrm{ml}$ dest. $\mathrm{H}_{2} \mathrm{O}$. The flask was closed by a cellulose stopper, covered by a piece of aluminium foil. Subsequently, a sterilisation step was conducted twice for $15 \mathrm{~min}$ at $121^{\circ} \mathrm{C}$ in an autoclave. The sterile medium was than infected with DON-producing strains of $F$. graminearum conidiospores (isolates: 142, 143, 144) under a clean bench and incubated for 21 days at $20^{\circ} \mathrm{C}$. The contents of a second sterile Erlenmeyer flask were not infected and were used for the production of a negative control.

Each Erlenmeyer flask was than extracted over night (16h) at $4^{\circ} \mathrm{C}$ with $40 \mathrm{ml}$ of sterile Tris-HCl buffer (25 mmol, pH 8) by gentle shaking (Pekkarinen and Jones, 2002). The Tris-HCl buffer extract was filtered over a hair sieve and the extract was centrifuged [15 min $6000 \mathrm{rpm}$ (x $3830 \mathrm{~g}$ )]. The cleaned Fusarium-infected extracts (+) and controls (-) were stored at $-20{ }^{\circ} \mathrm{C}$ for further experiments (Figure 1).

\section{Protein incubation and extraction}

Two sets of experiments were performed: 1. Digestion of gluten and consequent extraction of the individual gliadins and glutenins. 2. Digestion of the individually isolated and purified gliadins and glutenins followed by extraction schemes adapted to the new distribution/allocation patterns.

For proteolysis, $20 \mathrm{mg}$ gluten, gliadin and glutenin were weighed in $2 \mathrm{ml}$ reaction tubes (Figure 1). $1 \mathrm{ml}$ of protease extract was added for protein digestion at $37^{\circ} \mathrm{C}$ with gentle shaking for different incubation times (gluten $4 \mathrm{~h}, 24 \mathrm{~h}$; gliadin and glutenin $2 \mathrm{~h}, 4 \mathrm{~h}, 8 \mathrm{~h}$ ). To stop the proteolysis, $1 \mathrm{ml}$ of ice-cold $\left(-20^{\circ} \mathrm{C}\right)$ acetone with $20 \%$ trichloroacetic acid (TCA) was added to the reaction mixture, vortexed for $30 \mathrm{sec}$ and the samples were stored for $12 \mathrm{~h}$ at $-20^{\circ} \mathrm{C}$. The samples were then centrifuged for $20 \mathrm{~min}$ at $-9^{\circ} \mathrm{C}$ and $14000 \mathrm{rpm}$ ( $\mathrm{x} 20854 \mathrm{~g}$ ). For the individual gliadin and glutenin fractions, the supernatants were collected and stored at $-20 \mathrm{C}^{\circ}$ for RP-HPLC determination of the 
peptides (the gluten supernatant was discarded). Each pellet was then washed with icecold acetone at $-20^{\circ} \mathrm{C}$ for $30 \mathrm{~min}$, again centrifuged at the same conditions as given above and the pellet was finally dried under $\mathrm{N}_{2}$. In the following step, the pellet was than extracted twice by homogenisation with a hand mixer at $7000 \mathrm{rpm}$ (Xenox S.A. Xenox - Motorised Hand Tool, Wecker, Luxemburg), shaken for 20 min at $20^{\circ} \mathrm{C}$ with 1 $\mathrm{ml}$ of the extraction solution $\mathrm{B}$ and centrifuged for $20 \mathrm{~min}$ at $20^{\circ} \mathrm{C}$ and $14000 \mathrm{rpm}(\mathrm{x}$ $20854 \mathrm{~g})$. The resulting supernatant was divided into two aliquots - one for RP-HPLC and the other for SDS-Page.

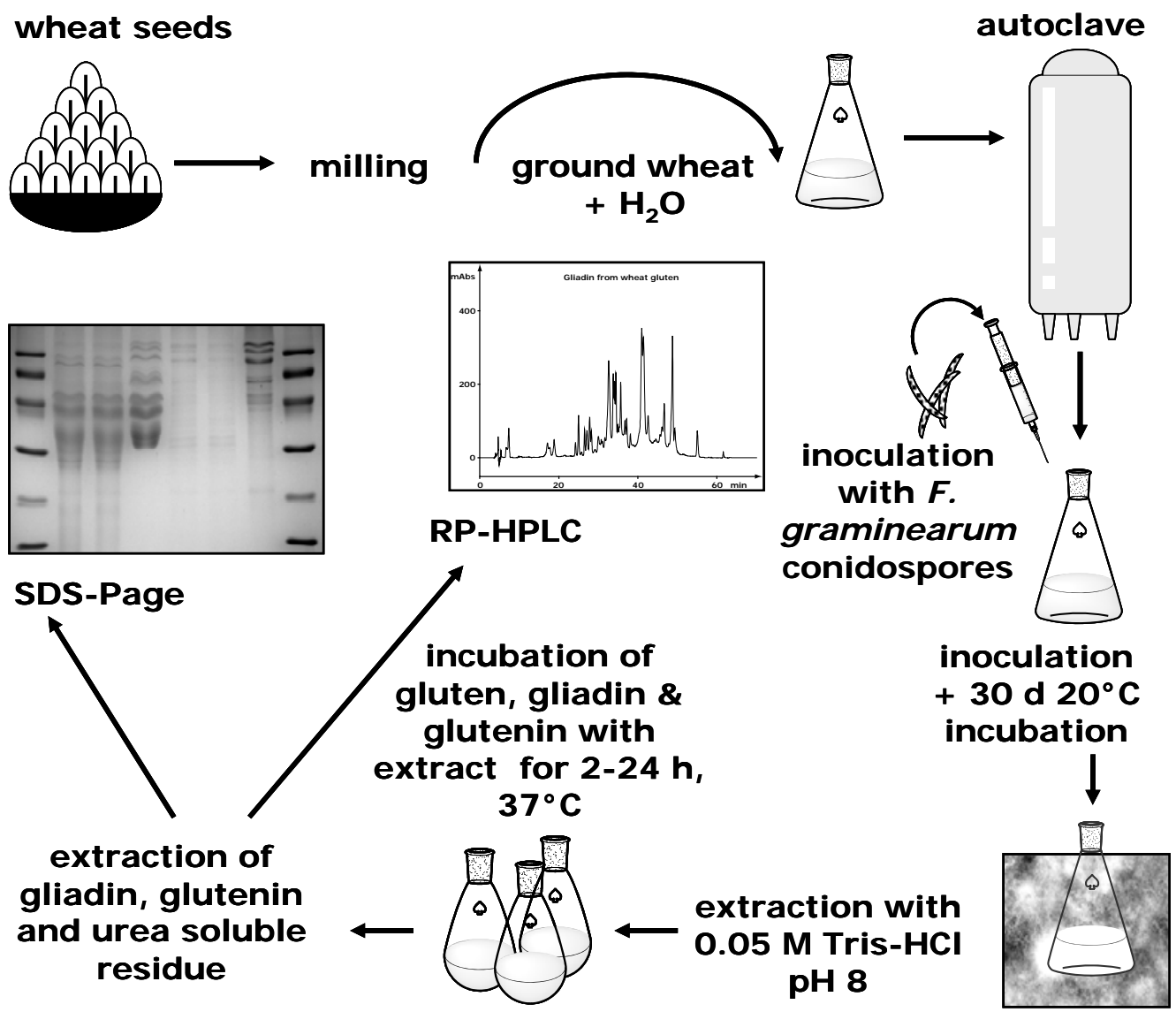

Figure 1 Model system for the isolation of Fusarium graminearum protease extract and degradation of wheat gluten and gluten fractions.

Wheat seeds were milled, mixed with water and autoclaved. The sterile medium was than infected with F. graminearum conidiospores (isolate: 142, 143, 144) and incubated for 30 days at $20^{\circ} \mathrm{C}$. Soluble fractions were than isolated with Tris- $\mathrm{HCl}$ and the extract used for incubation and degradation of the gluten and gluten fractions for different periods. After stopping the reaction, the proteins and peptides were isolated and detected by RP-HPLC and SDS-Page. 
The pellets resulting from the gluten and glutenin experiments were washed with icecold acetone at $-20^{\circ} \mathrm{C}$ for $30 \mathrm{~min}$, centrifuged again at the same conditions as given above and the pellets finally dried under $\mathrm{N}_{2}$. In the next step, these pellets were then extracted twice by homogenisation with a hand mixer at $7000 \mathrm{rpm}$ (Xenox S.A. Xenox - Motorised Hand Tool, Wecker, Luxemburg), shaken for $30 \mathrm{~min}$ at $60^{\circ} \mathrm{C}$ under $\mathrm{N}_{2}$ with $1 \mathrm{ml}$ of the extraction solution $\mathrm{C}$, and centrifuged for $20 \mathrm{~min}$ at $20^{\circ} \mathrm{C}$ and $14000 \mathrm{rpm}$. The supernatants were divided into two aliquots - one for RP-HPLC and the other for SDS-Page. The residue gluten pellet was further solubilised with $2 \mathrm{ml} 8 \mathrm{M}$ urea (solution D) for $10 \mathrm{~min}$ in an ultrasonic bath and shaken for $30 \mathrm{~min}$ at room temperature before being divided into two aliquots - one for RP-HPLC and the other for SDS-Page.

For the sample preparation for the SDS-page, $1 \mathrm{ml}$ ice-cold $\left(-20^{\circ} \mathrm{C}\right)$ acetone with $20 \%$ TCA was added to a $1 \mathrm{ml}$ sample resulting from the extraction steps with the solutions $\mathrm{B}, \mathrm{C}$ or D. The samples were stored for $12 \mathrm{~h}$ at $-20^{\circ} \mathrm{C}$. The samples were then centrifuged for $20 \mathrm{~min}$ at $-9^{\circ} \mathrm{C}$ and $14000 \mathrm{rpm}$ (x $20854 \mathrm{~g}$ ). The pellets were washed with ice-cold acetone and dried under $\mathrm{N}_{2}$.

$R P-H P L C$

A dual pump mode Shimadzu 10A system (Duisburg, Germany) with a PerfectSil 300 C8 column 300 x 4.5 mm, $300 \AA \AA, 5 \mu \mathrm{m}$ (MZ-Analysentechnik GmbH, Mainz, Germany) was used for the HPLC. The flow rate was $1 \mathrm{ml} / \mathrm{min}$ and detection was performed at $220 \mathrm{~nm}$ with a column temperature of $50^{\circ} \mathrm{C}$. The two eluents were $\mathrm{A}=$ $0.1 \%$ TFA in dest. $\mathrm{H}_{2} \mathrm{O}$ and $\mathrm{B}=$ acetonitrile. The gradient was applied under the following conditions: $100 \%$ eluent A, 0 min; $76 \%$ eluent A, 5 min; $50 \%$ eluent A, 50 min; $10 \%$ eluent A, $51 \mathrm{~min} ; 10 \%$ eluent A, $56 \mathrm{~min} ; 100 \%$ eluent A, 57-70 min (regeneration/equilibration). The injection volume of the samples was $100 \mu 1$ for the peptide fraction, $50 \mu \mathrm{l}$ for the gliadins and glutenins and for the solution-B-soluble glutenins $200 \mu$ l. The quantification was performed by a stable sample quantity of 20 mg using the AUC (area under the curve) for quantification.

\section{SDS-Page}

A mini SDS-Page (Bio-Rad Laboratories GmbH, Munich, Germany) according to the method of Laemmli (1970) was used. The separation conditions of the gel were for the separating gel 14\% $\mathrm{T}$ and the connecting gel 10\% $\mathrm{T}$. The samples were dissolved in a sample buffer with the following composition: 4\% SDS (sodium dodecyl sulphate), 12\% glycerol, $0.61 \%$ Tris- $\mathrm{HCl}, 5 \%$ mercaptoethanol, 1\% DTE (dithioerithrol) and 
0.01\% Comassie Brilliant Blue R 250 with $\mathrm{pH}$ 6.8. The protein pellets were dissolved in $1 \mathrm{ml}$ sample buffer for gliadin, glutenin and urea-soluble fraction and in $200 \mu 1$ sample buffer for solution-B-soluble glutenins. The protein solution was treated for $5 \mathrm{~min}$ in an ultrasonic bath, heated at $90^{\circ} \mathrm{C}$ for $3 \mathrm{~min} .10 \mu \mathrm{l}$ of the sample solution were applied to each slot. A standard of $10 \mu \mathrm{l}$ of LMW calibration proteins (Amersham Bioscience Europe $\mathrm{GmbH}$, Freiburg, Germany) dissolved in $300 \mu \mathrm{l}$ sample buffer were added to each gel as molecular weight markers.

\section{Quantitative nitrogen analysis}

The nitrogen content was quantitatively measured with a $\mathrm{C} / \mathrm{N}$-analyser (Vario MAX CN Elementar Analyse system GmbH, Hanau, Germany). The N content of a 100-mg dried whole grain flour sample from each proband was analysed and converted into protein by using the factor 5.7 for wheat (ICC No. 105/2).

\section{Statistical treatment}

Generally, the analyses were repeated at least three times and evaluated by their means and standard deviations using Excel 2003.

\section{Results}

\section{Characterisation of isolated gliadin and glutenin fractions}

Separated gliadin and glutenin from commercial wheat gluten showed purity for gliadin of around $93 \%$ and for glutenin of $100 \%$ (Table 1 ). The $\mathrm{C} / \mathrm{N}$ ratio in the glutenin fraction was lower than in the gliadin fraction, resulting in ratios of $1: 2$ and 1:3, respectively.

Table $1 \mathrm{C} / \mathrm{N}$ ratio and protein content of the purified gluten fractions - gliadin and glutenin after isolation using the factor 5.7 for calculation as for the wheat gluten (ICC No. $105 / 2)$

\begin{tabular}{ccccc}
\hline $\begin{array}{c}\text { Protein } \\
\text { fraction }\end{array}$ & C/N Ratio & Protein (\% DM) \\
\hline Gliadin & $3.13 \pm 0.010$ & $93.41 \pm 0.19$ \\
Glutenin & 2.15 & \pm 0.004 & $100.00 \pm 0.88$ \\
\hline
\end{tabular}

The detected molecular weight, expressed in $\mathrm{kDa}$, of the fractionated RP-HPLC spectrum for gliadin showed for the $\omega-, \alpha$-, and $\gamma$-gliadins different bands in the SDS- 
page profile as documented in Figure 2a. Only one small band at $70 \mathrm{kDa}$ was found for the 65 -gliadins, whereas two major bands at 80 and $62 \mathrm{kDa}$ could be detected for the $\omega 1,2$-gliadins. In connection to the SDS-page of gliadin (Figure 2c), we found bands between $111 \mathrm{kDa}$ and $61 \mathrm{kDa}$ which can be classified as $\omega$-gliadins. The $\alpha$-gliadin fraction (Figure 2a) was separated in five fractions. The main part of the protein found here had molecular weights in the range of 37-50 kDa with a few low (LMW) as well as high molecular weight (HMW) components. Gliadins of the $\gamma$-type (Figure 2a) were found in general between 30 and $50 \mathrm{kDa}$, overlapping in their molecular weights with those of the $\alpha$-gliadin fraction (Figure 2c). The fractionation of the glutenin components shows for the $\omega b$-glutenin fraction a main molecular weight around 80 and $60 \mathrm{kDa}$ (Figure $2 \mathrm{~b}$ ). Some of these protein bands were also found in the SDS-page of total glutenin (Figure 2c). HMW-GS could be detected mainly around 80 and $108 \mathrm{kDa}$ in the glutenin fraction (Figures 2b, 2c), while the LMW-GS were fractionated in four parts and showed a molecular weight distribution between 35-50 kDa (Figures 2b, 2c). 


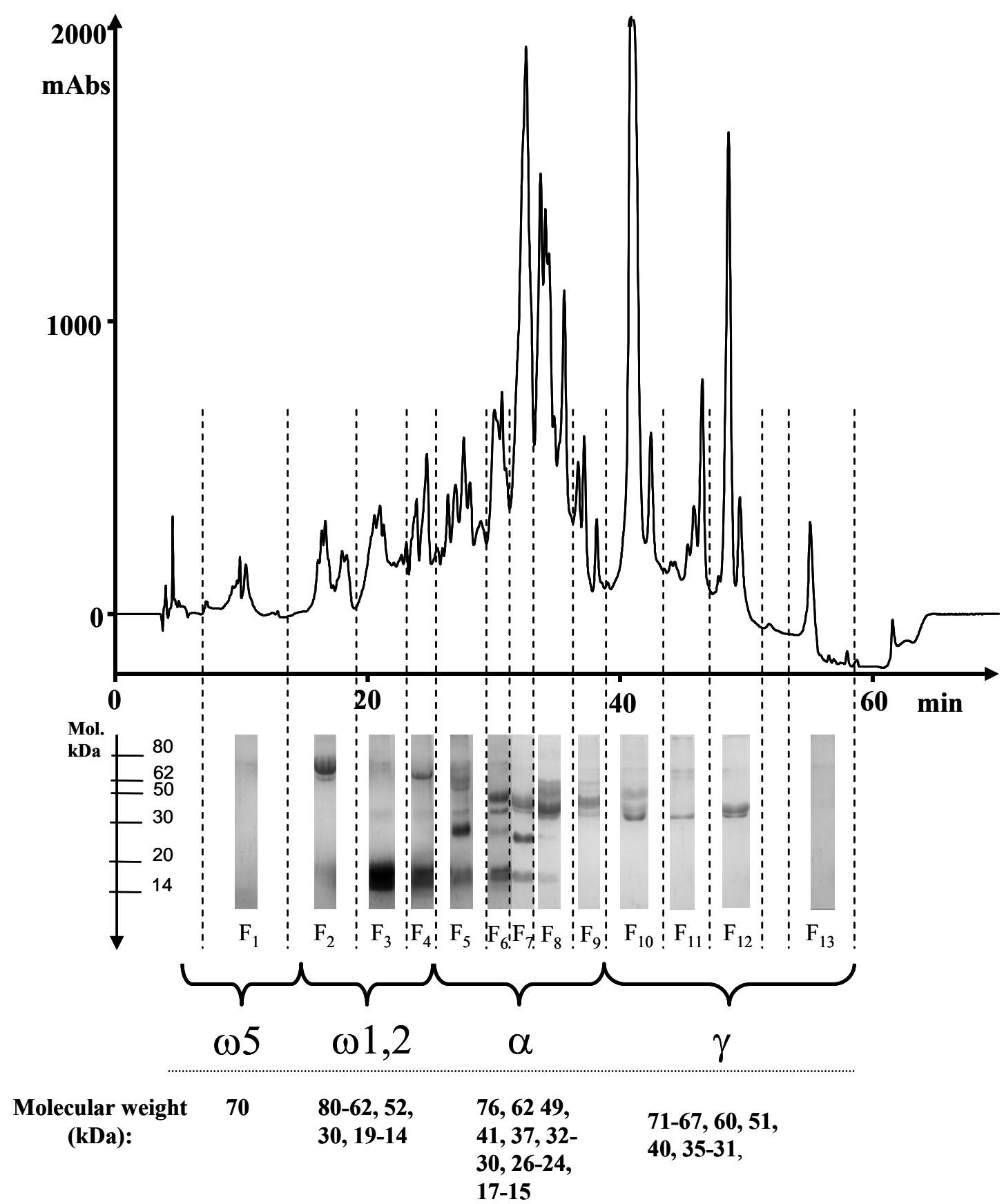

Figure 2a Results of the fractionated and freeze-dried samples showing the allocation of the RP-HPLC peaks of wheat gliadin to the corresponding identified molecular weights by SDS-Page in $\mathrm{kDa}$ (molecular weight); mAbs, micro absorption units

These results document the easier assignment of glutenin components in SDS-page in comparison to the different gliadin types (Figure $2 \mathrm{c}$ ). The changes in quantity between RP-HPLC and SDS-page are based, according to our observations, in the individual colouration of the diverse fractions with Comassie and the stability retention of this colouration. 


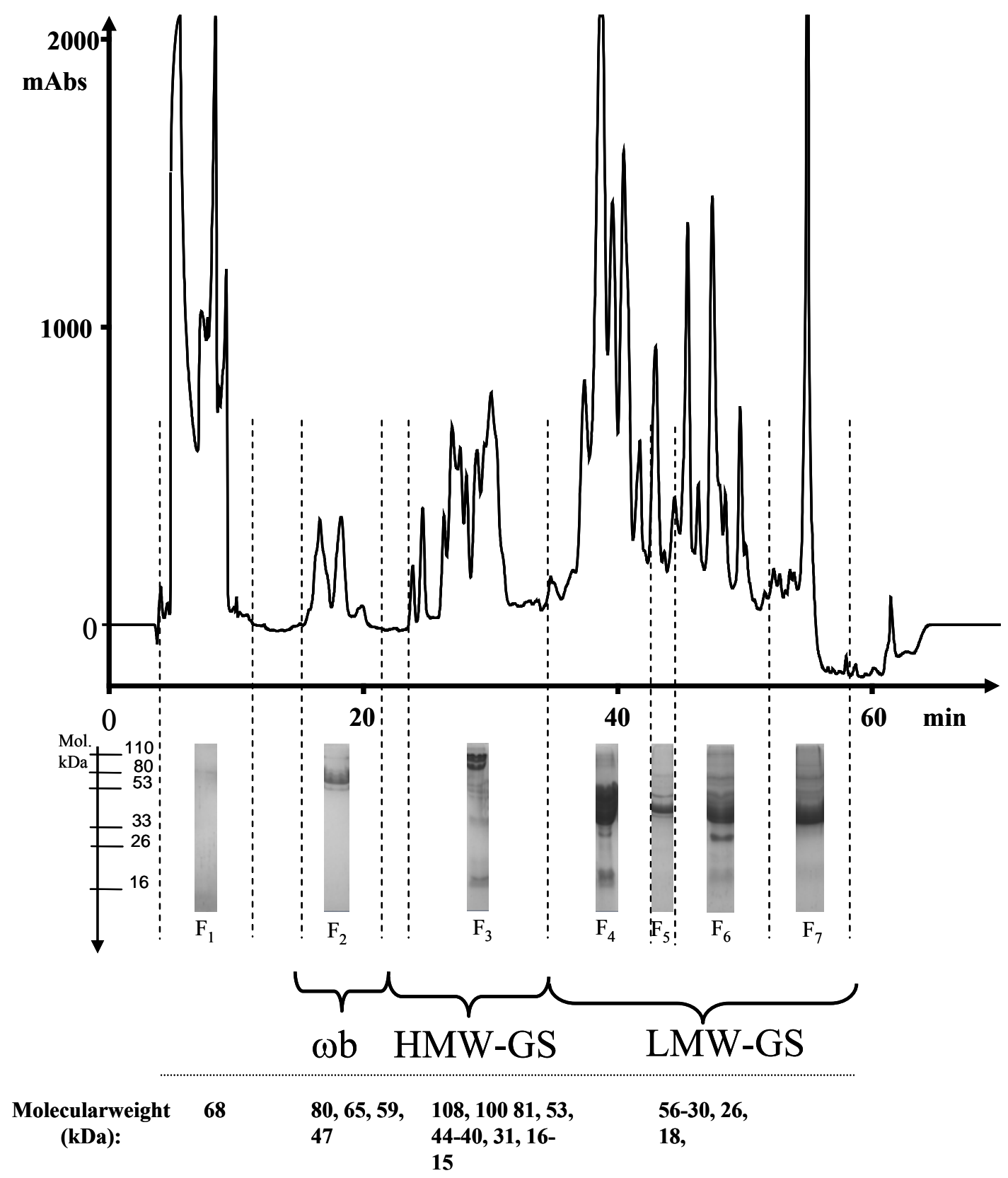

Figure 2b Results of the fractionated and freeze-dried samples showing the allocation of the RP-HPLC peaks of wheat glutenin to the corresponding identified molecular weights by SDS-Page in $\mathrm{kDa}$ (molecular weight); mAbs, micro absorption units 


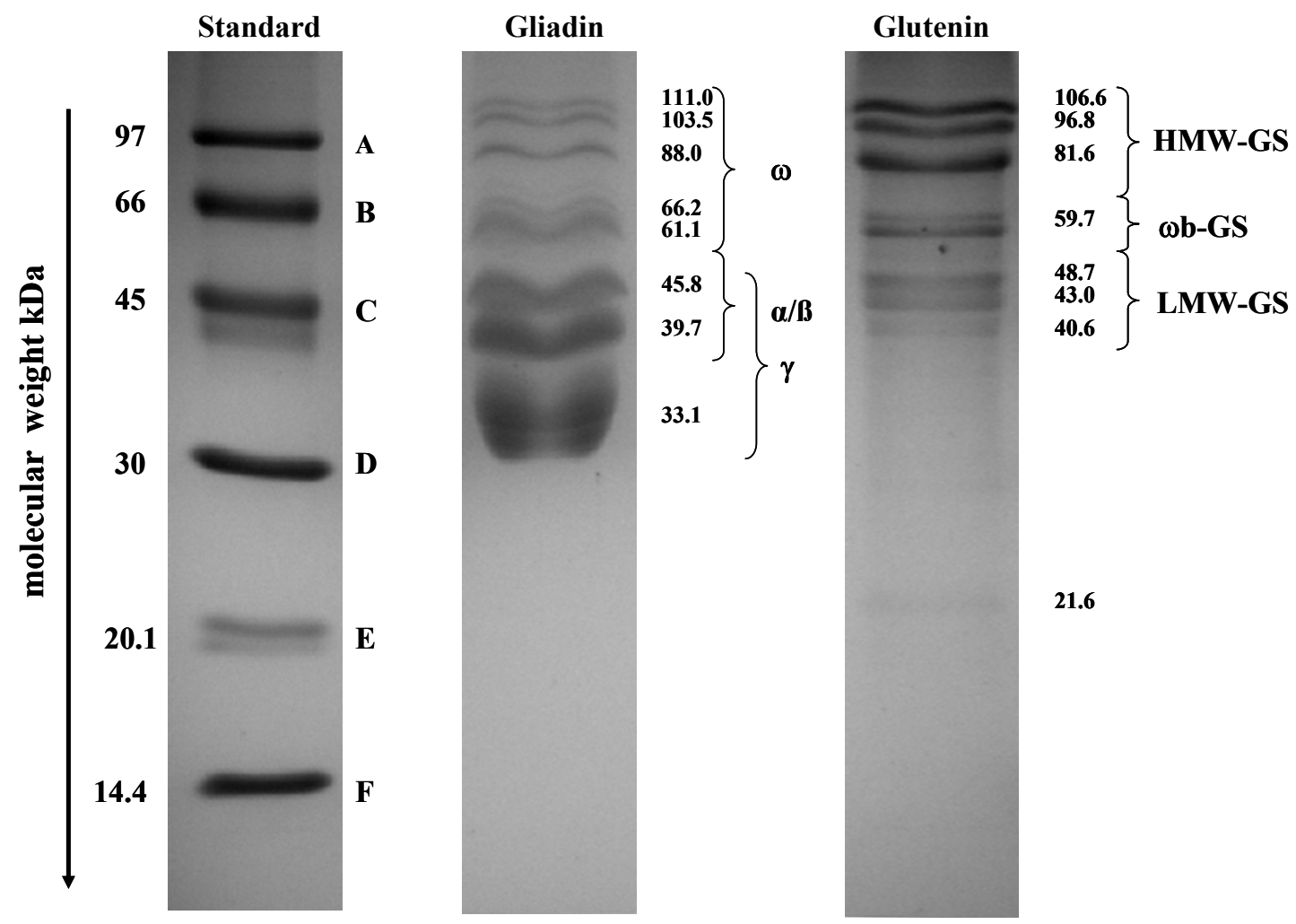

Figure 2c Allocation of the wheat gliadin and glutenin subfractions to the corresponding isolated and purified control. Standard (A: phosphorylase; B: bovine serum albumin; C: ovalbumin; D: carbonic anhydrase; E: trypsin inhibitor; F: lysozyme; Amersham Pharmacia Biotech, GE Healthcare Europe GmbH, Munich, Germany)

Digestion of wheat gluten by Fusarium graminearum protease

In this set of experiments, the gluten was first digested with Fusarium proteases and the characterisation by the extraction performed thereafter.

Incubation of gluten for $4 \mathrm{~h}$ with Fusarium proteases showed a relatively higher degradation of the glutenin fractions compared to that of the gliadins (Figures $3 a-b$ ). The glutenins were almost completely degraded, whereas the extent of gliadin breakdown reached approximately 20\% (Figures 3c-d). The individual gliadin types were affected to different extents. The order was the 11,2 -gliadins were the most strongly affected, followed by $\gamma$-gliadins and $\omega 5$-gliadins with a slight increase in the quantity of $\alpha$-gliadins (Figure 3c). No consistent degradation pattern could be discerned for the glutenin types. The HMW-GS were almost completely degraded, followed by the LMW-GS. The $\omega \mathrm{b}$-glutenins were affected to a similar extent as that observed for the 1 1,2-gliadins (Figures 3c-d). The SDS-page of the digested samples compared to 
the control supports the RP-HPLC data and demonstrates the degradation of the gliadins and glutenins to lower molecular weight fragments (Figure 3d). After 24 hours of incubation, the gliadin fraction was completely degraded and the glutenin fraction showed some new peaks around $20 \mathrm{~min}$ and $50 \mathrm{~min}$ (Figures $3 \mathrm{a}-\mathrm{b}$ ).

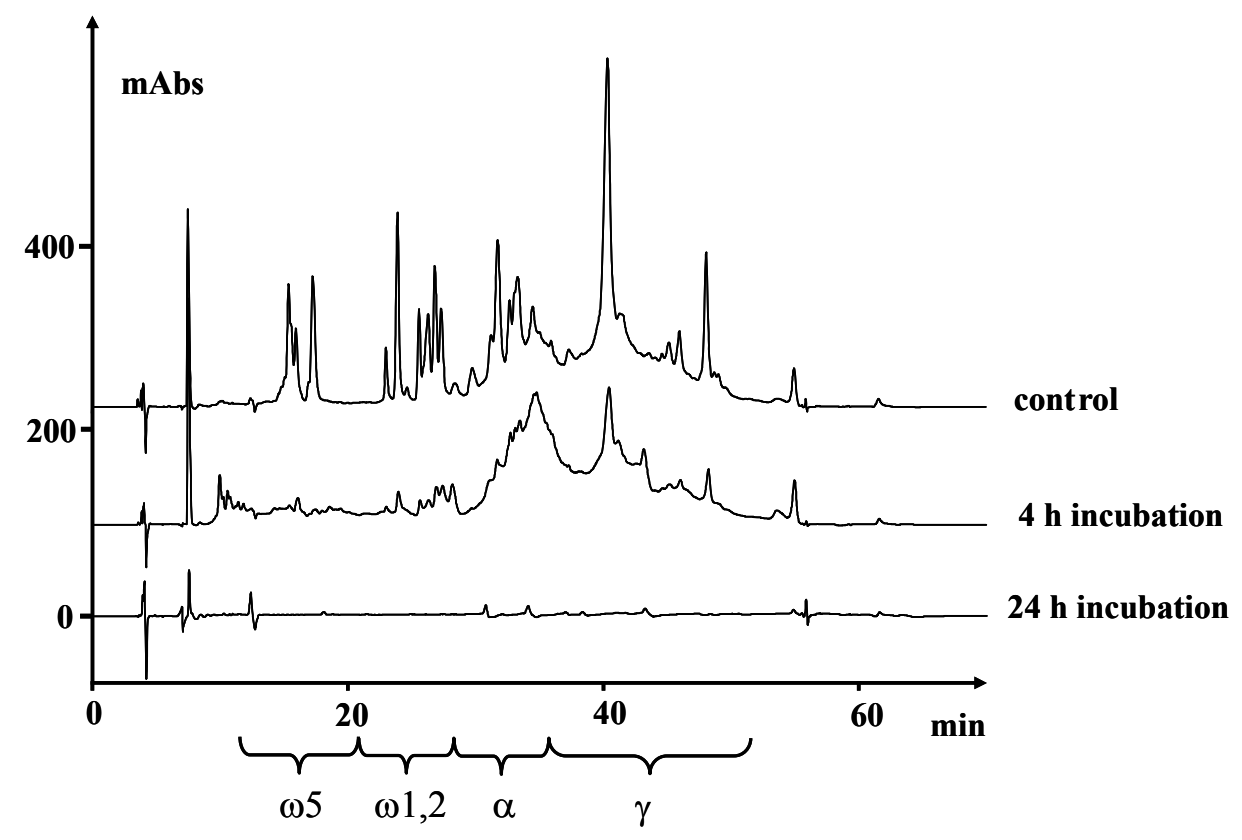

Figure 3a RP-HPLC of degraded wheat gliadin subfractions extracted from gluten (Sigma-Aldrich, Munich, Germany) after time-dependant treatment with Fusarium graminearum protease

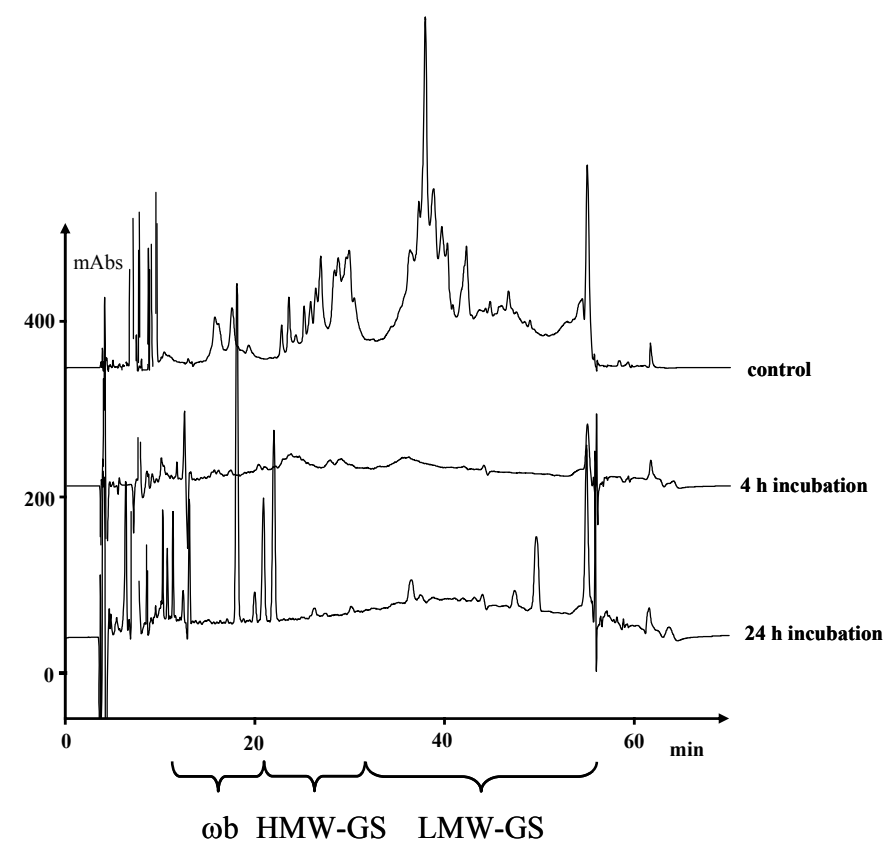

Figure 3b RP-HPLC of degraded wheat glutenin subfractions extracted from gluten (Sigma-Aldrich, Munich, Germany) after time-dependant treatment with Fusarium graminearum protease 


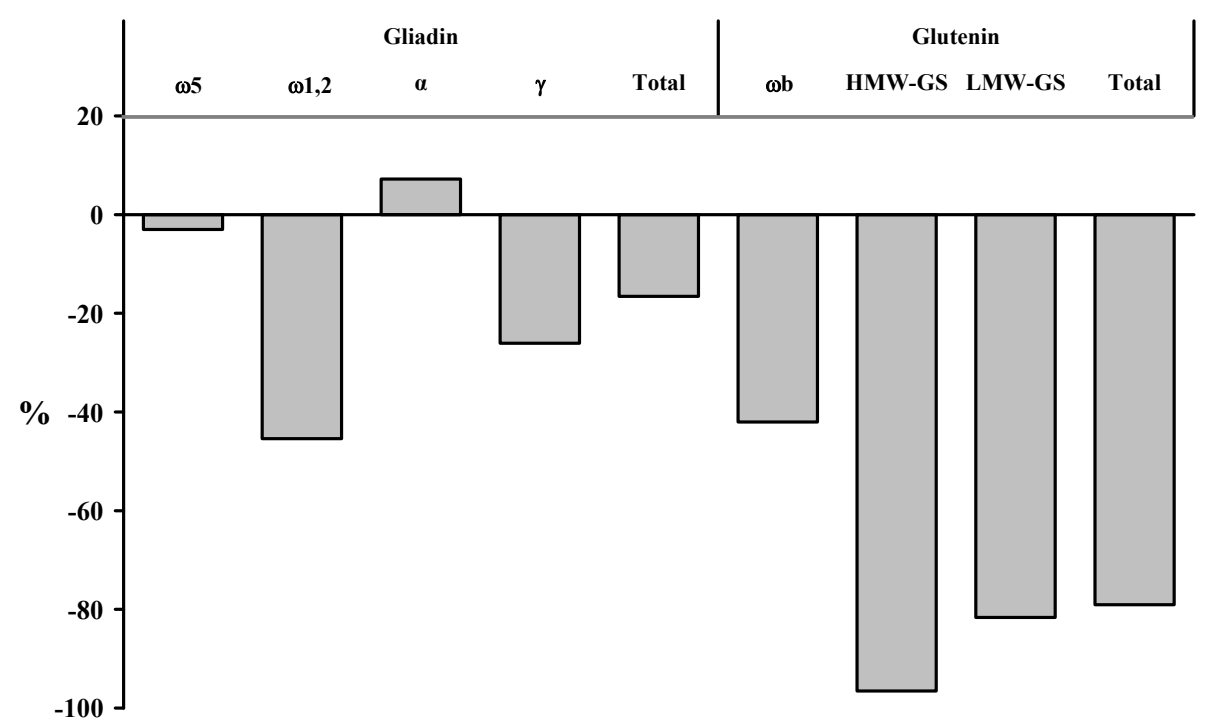

Figure 3c Results of RP-HPLC showing the degradation (\% AUC) of wheat gliadin and glutenin subfractions extracted from gluten (Sigma-Aldrich, Munich, Germany) after a 4-h treatment with Fusarium graminearum protease

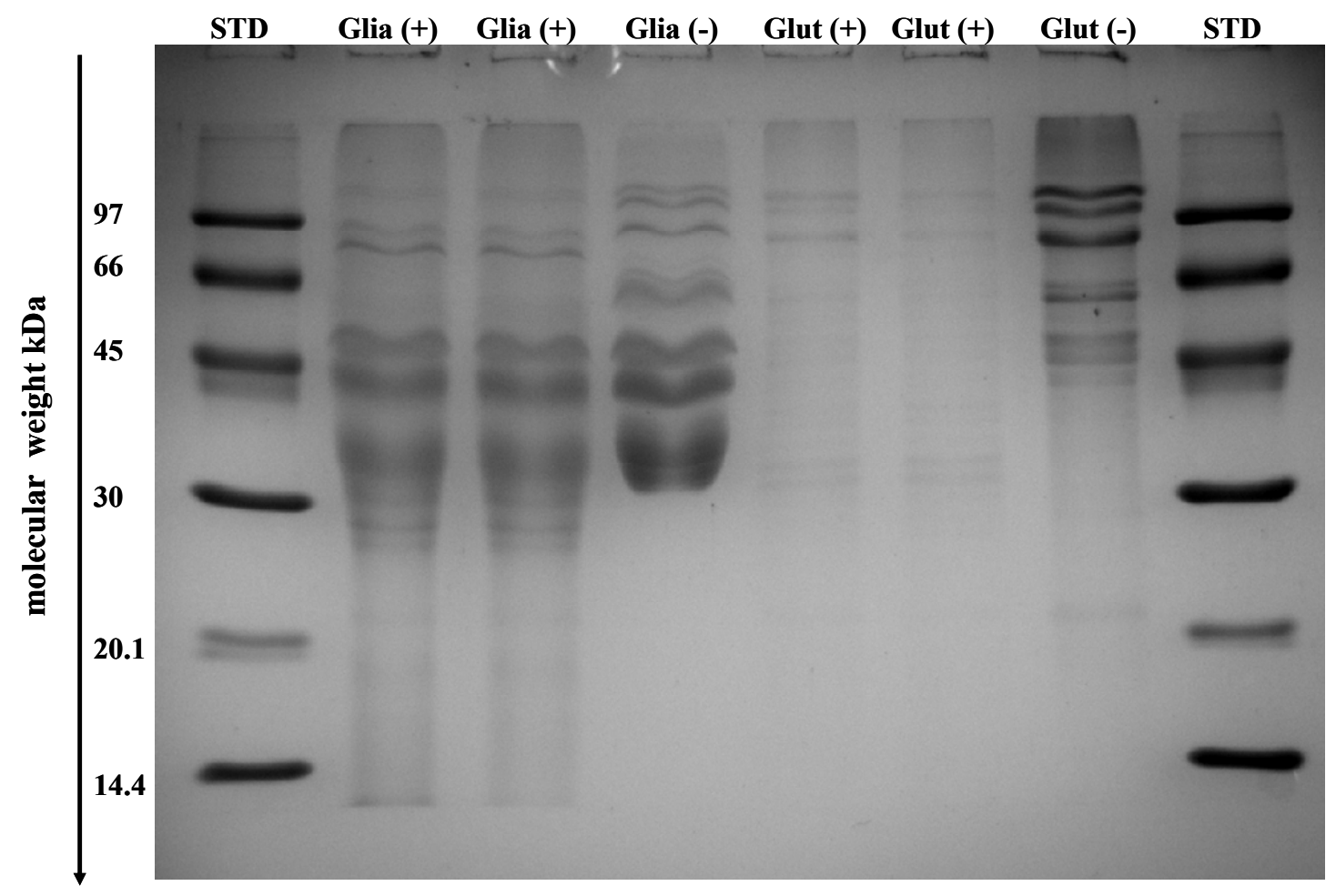

Figure 3d Results of SDS-Page showing the degradation of wheat gliadin and glutenin subfractions extracted from gluten (Sigma-Aldrich, Munich, Germany) after a 4-h treatment with Fusarium graminearum protease. Key: STD $=$ Standard; Glia $(+)=$ protease-degraded gliadin; Glia $(-)=$ control gliadin; Glut $(+)=$ protease-degraded glutenin; Glut (-) = control glutenin .

Digestion of purified gliadin and glutenin by Fusarium graminearum protease 
In this set of experiments, the individual gliadins and glutenins were first extracted and purified, then digested by the Fusarium proteases and finally, a new characterisation by the extraction scheme was performed thereafter.

Table 2 Peptide formation from isolated gliadin (Fig. 4a), glutenin (Fig. 5a) and the amounts of degraded glutenins soluble in the gliadin extraction solution B (Fig. 5d) after time-dependent Fusarium graminearum protease treatment

\begin{tabular}{|c|c|c|c|c|c|c|c|c|}
\hline \multirow{3}{*}{$\begin{array}{c}\text { Protein fraction } \\
\text { Gliadin }\end{array}$} & \multirow{2}{*}{\multicolumn{2}{|c|}{ control }} & \multicolumn{2}{|c|}{$2 \mathrm{~h}$ incubation } & \multicolumn{2}{|c|}{$4 \mathrm{~h}$ incubation } & \multicolumn{2}{|c|}{$8 \mathrm{~h}$ incubation } \\
\hline & & & \multicolumn{4}{|c|}{ peak area $* 10^{-6}$} & & \\
\hline & 2.9 & \pm 1.8 & 28.4 & \pm 1.7 & 54.9 & \pm 1.3 & 84.0 & \pm 3.9 \\
\hline Glutenin & 0.7 & \pm 0.4 & 44.4 & \pm 0.2 & 67.4 & \pm 10.9 & 89.2 & \pm 2.7 \\
\hline $\begin{array}{l}\text { Glutenins soluble } \\
\text { in gliadin } \\
\text { fraction }\end{array}$ & 45.5 & \pm 3.2 & 66.6 & \pm 29.2 & 71.6 & \pm 0.5 & 74.4 & \pm 7.7 \\
\hline
\end{tabular}

The destruction of gliadin by Fusarium proteases led, depending on the incubation time, to a rise in the peptide fraction (Table 2, Figure 4a), accompanied by a strong depletion of the individual gliadin subfractions (Table 3, Figure 4b). The $\omega 5$-gliadin fraction was more strongly affected, whereas the other fractions ( $\omega 1,2-, \alpha$ - and $\gamma$-gliadins) could be allocated with a similar time-dependent degradation pattern (Table 3). After 2 hours of incubation with the protease, most of the gliadin was degraded and therefore, the main fractions were not detected in the corresponding SDS-page gel (Figure 4c). 


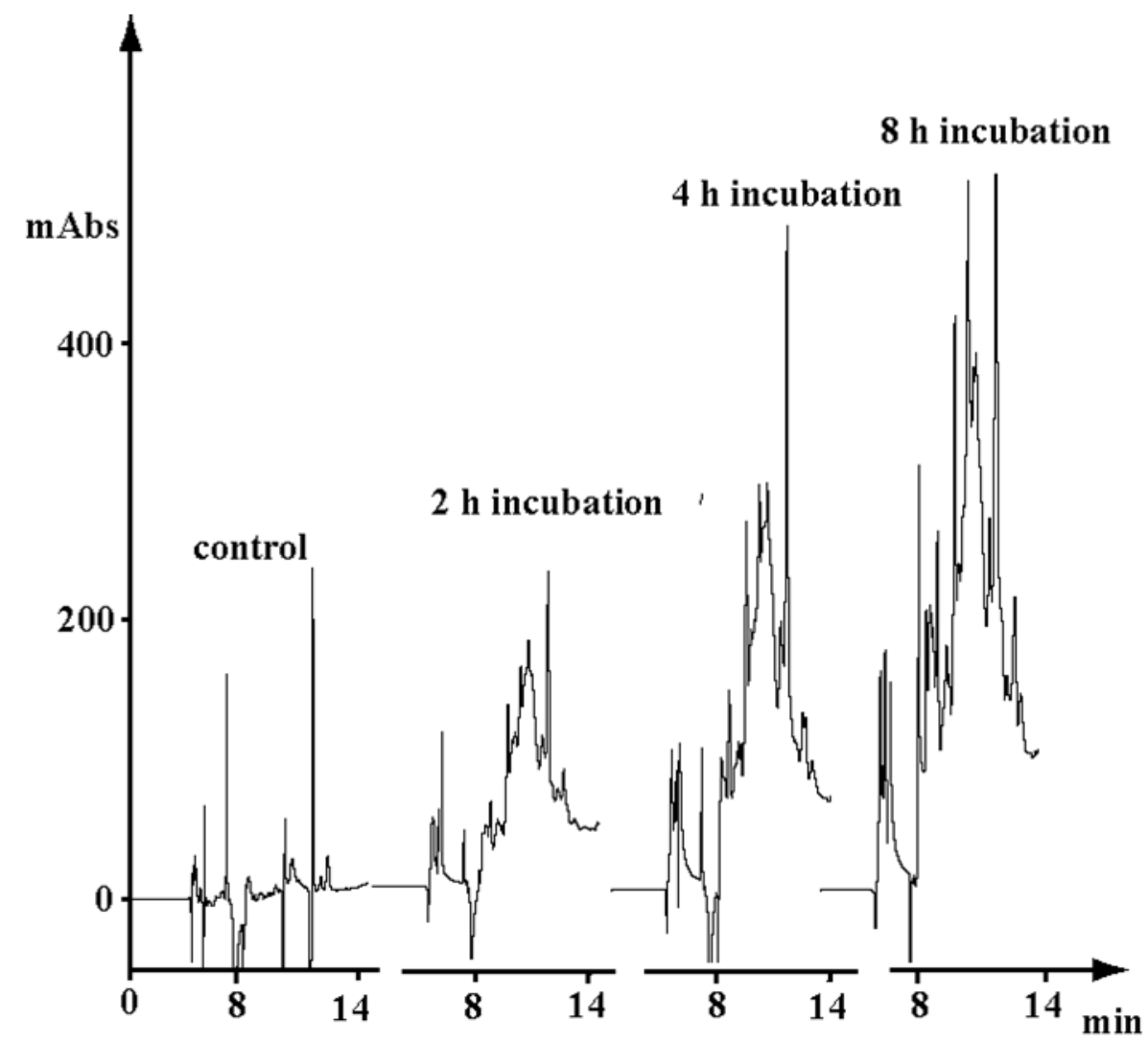

Figure 4a RP-HPLC of isolated and purified gliadin - peptide formation by Fusarium graminearum protease treatment after different incubation periods; mAbs, microabsorption units

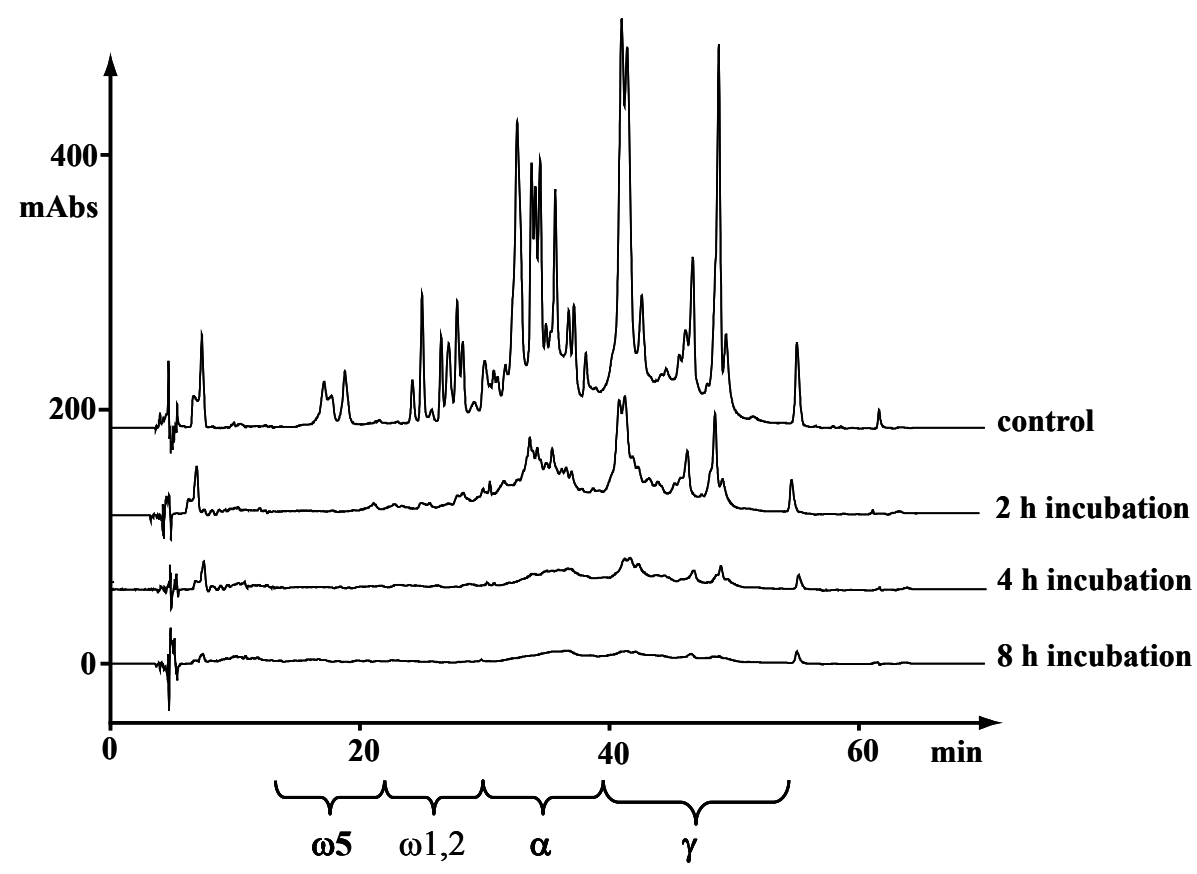

Figure 4b RP-HPLC of isolated and purified gliadin - degradation after time-dependant treatment with Fusarium graminearum protease (Gliadin subfractions: $\omega 5$-Gliadins, $\omega 1,2$-Gliadins, $\alpha$-Gliadins, $\gamma$-Gliadins) 


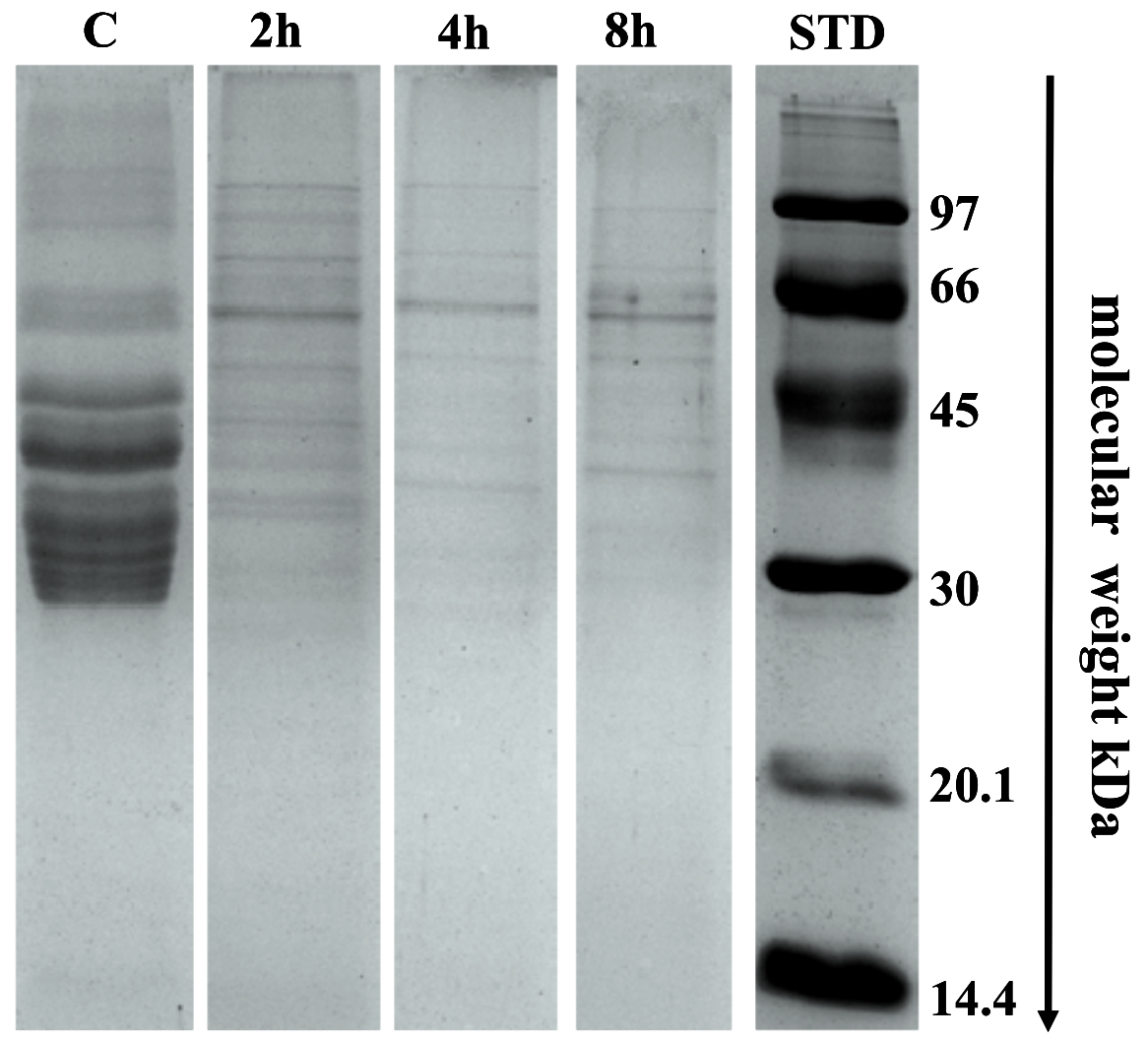

Figure 4c SDS-Page of isolated and purified gliadin - degradation after time-dependant (2-8h) treatment with Fusarium graminearum protease (STD: standard; C: control)

Table 3 The amount of gliadin (Fig.4b) and glutenin (Fig. 5b) sub-types remaining (peak area in \%) after Fusarium graminearum protease treatment after different incubation times in comparison to the undigested protein control

\begin{tabular}{|c|c|c|c|c|}
\hline $\begin{array}{l}\text { Protein } \\
\text { fraction }\end{array}$ & Sub-type & $2 \mathrm{~h}$ incubation & $4 \mathrm{~h}$ incubation & $8 \mathrm{~h}$ incubation \\
\hline \multirow{5}{*}{ Gliadin } & $\omega 5$ & 12 & 11 & 14 \\
\hline & $\omega 1,2$ & 22 & 9 & 6 \\
\hline & $\alpha$ & 24 & 12 & 6 \\
\hline & $\gamma$ & 25 & 12 & 6 \\
\hline & Total & 23 & 12 & 6 \\
\hline \multirow{4}{*}{ Glutenin } & $\omega b$ & 100 & 100 & 90 \\
\hline & HMW-GS & 61 & 53 & 42 \\
\hline & LMW-GS & 87 & 72 & 57 \\
\hline & Total & 84 & 70 & 55 \\
\hline
\end{tabular}


Similarly, the breakdown of glutenin proceeded with a rise in peptide formation (Table 2, Figure 5a). The peptide formation was after $2 \mathrm{~h}$ of incubation higher than with gliadin, though in the later stages it was in the same range as gliadin. This was documented also in the corresponding depletion of the subfractions (Table 3, and Figures 5b,c). The degradation appeared to occur at a lower extent than that of the gliadin subfractions. This is in contrast to the observations made for gluten digestion documented before (Figures 3a-d). A comparison of the glutenin subfractions showed that HMW-GS was again most strongly affected by the protease treatment, followed by LMW-GS, with the $\omega b$-fraction being hardly affected at all; which in turn conforms with the results obtained from the gluten digestion. The formation of a fraction that was more soluble in the gliadin extraction solution B after protease treatment was also observed (Table 2, Figure 5d). These results show that fragments from the purified glutenin were now allocated to the gliadin subfractions and their amount increased with the incubation time. After 8 hours of incubation, two bands were visible in SDS-page gel as compared to the control (Figure 5e).

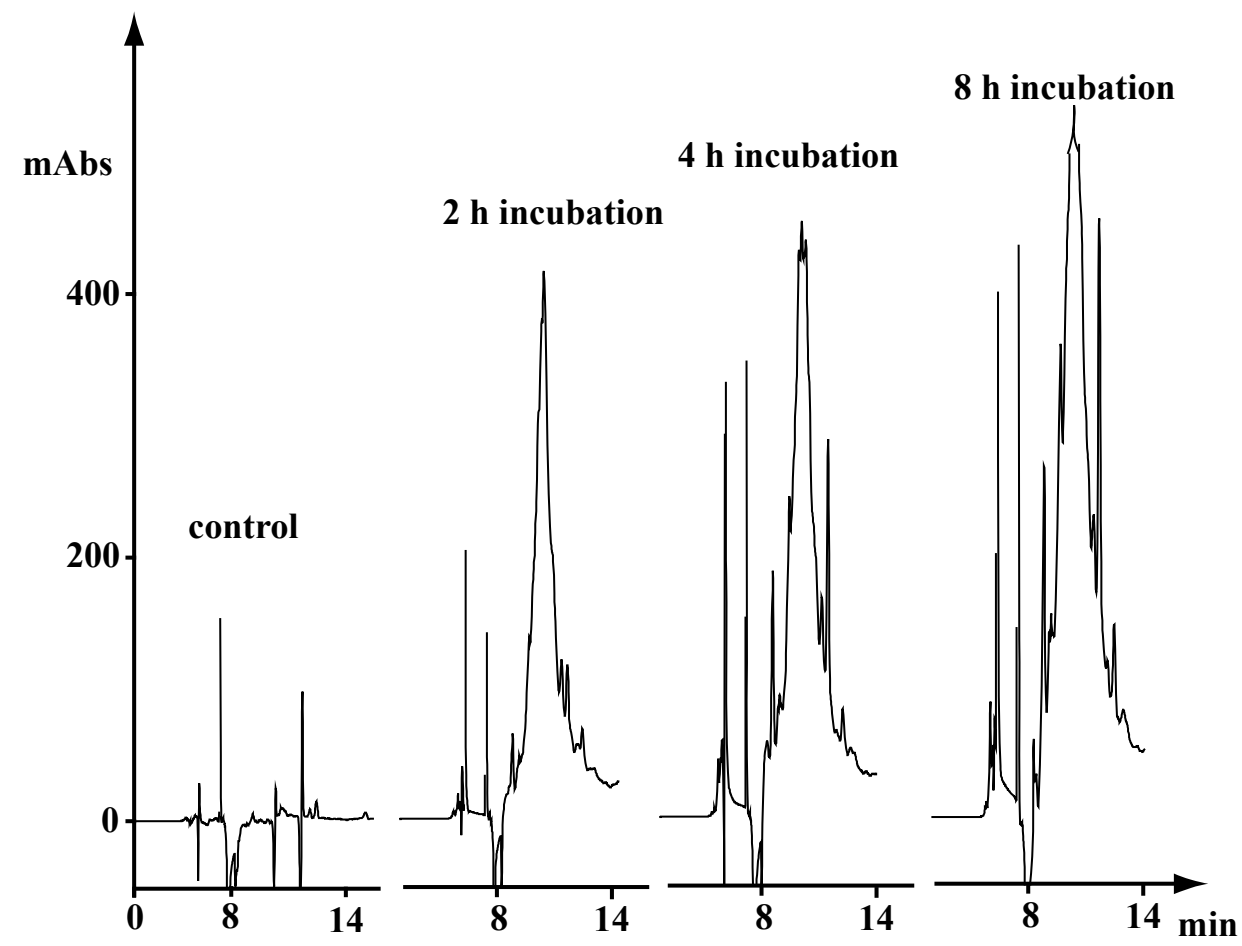

Figure 5a RP-HPLC of isolated and purified glutenin - peptide formation by Fusarium graminearum protease treatment after different incubation periods; mAbs, microabsorption units 


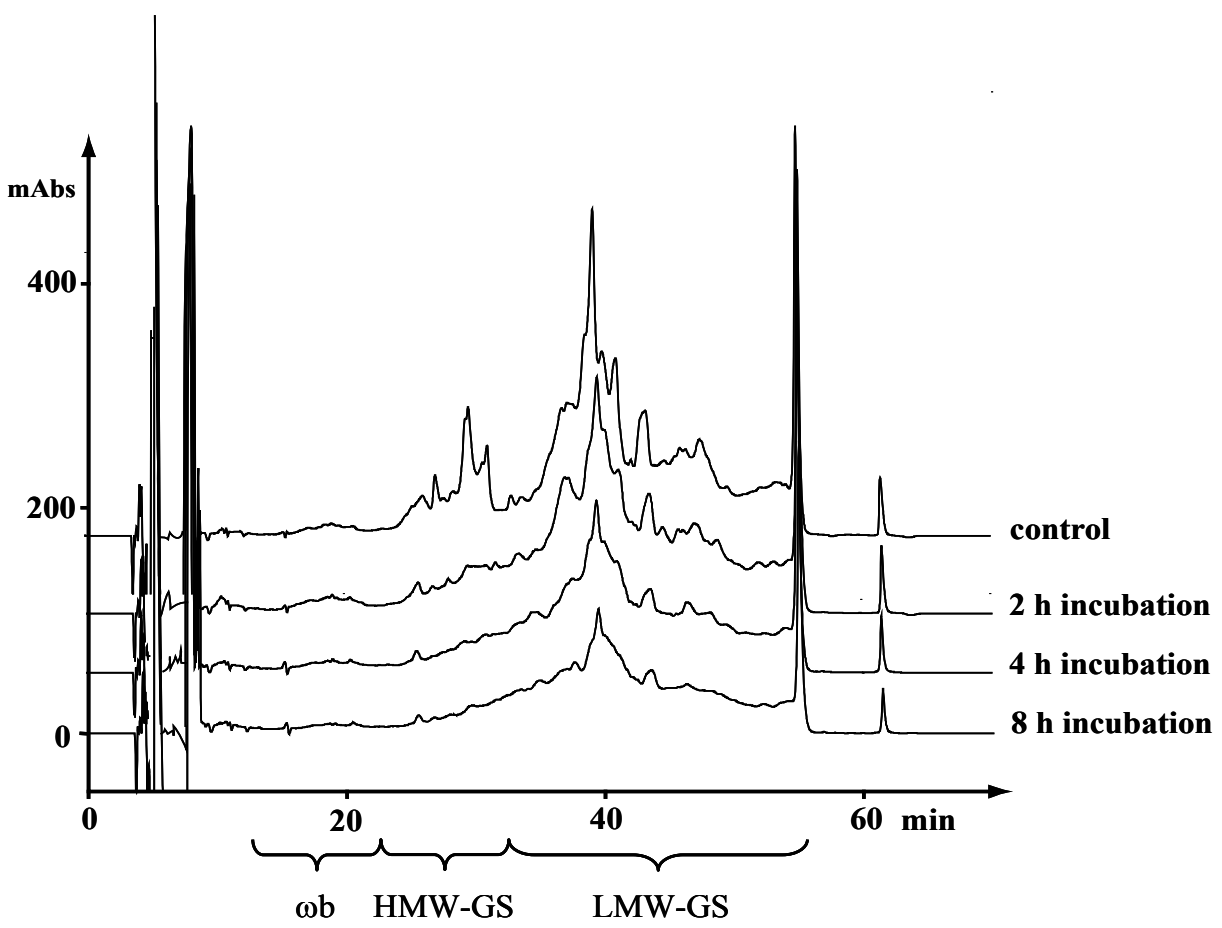

Figure 5b RP-HPLC of isolated and purified glutenin - degradation after timedependant treatment with Fusarium graminearum protease (glutenin subfractions: $\omega b-$ Glutenins, HMW-GS, LMW-GS)

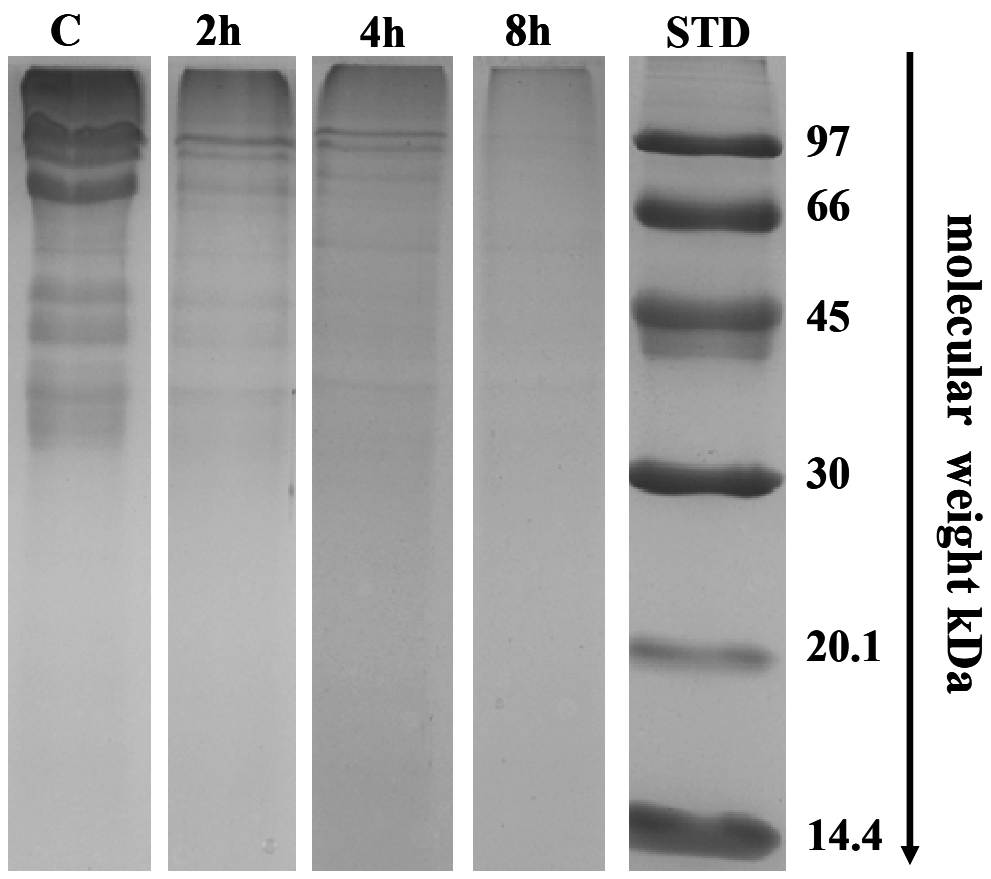

Figure 5c SDS-Page of isolated and purified glutenin - degradation after timedependant (2-8h) treatment with Fusarium graminearum protease (STD: standard; C: control) 


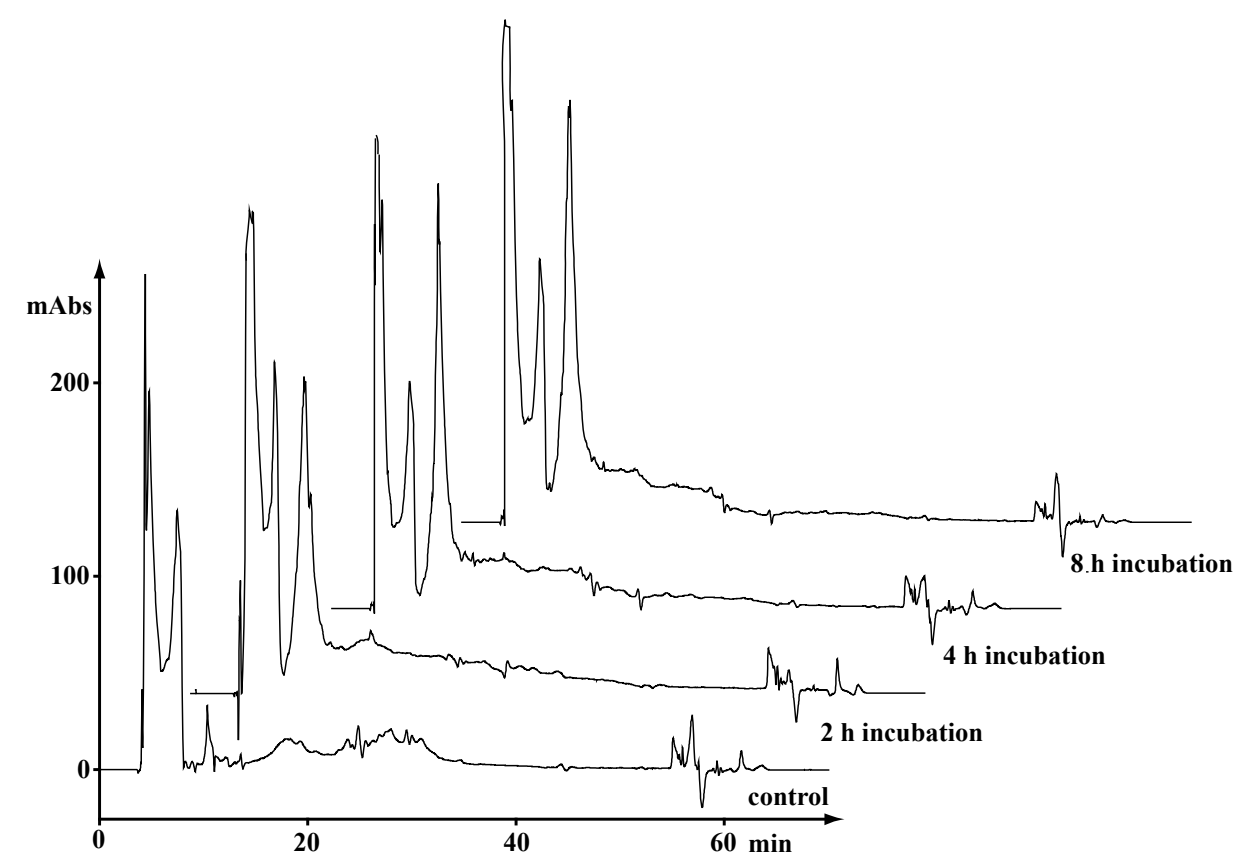

Figure 5d RP-HPLC of degraded purified glutenins soluble in the gliadin extraction solution B after time-dependant Fusarium graminearum protease treatment; mAbs, micro-absorption units

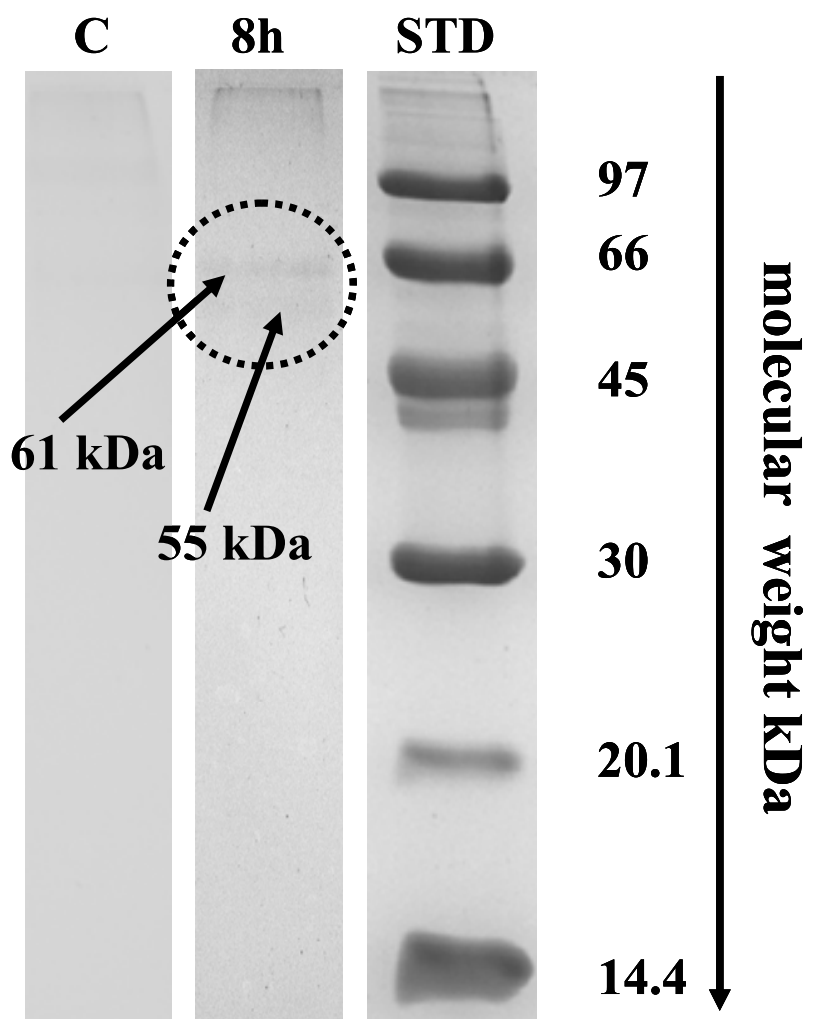

Figure 5e SDS-Page of degraded purified glutenins soluble in the gliadin extraction solution B after an 8-h incubation period with Fusarium graminearum protease in comparison to the non-treated control (STD: standard; C: control) 


\section{Discussion}

\section{Characterisation of isolated gliadin and glutenin fractions}

The separated gliadin and glutenin fraction showed differences in the $\mathrm{C} / \mathrm{N}$ ratio (Table 1). The higher $\mathrm{N}$ quantity of glutenin in comparison to gliadin can be derived from their specific amino acid composition (Shewry and Halford, 2002). Both the gliadin and glutenin fractions are characterised by different concentrations of amino acids with more than one nitrogen atom in the molecule (asparagine, glutamine, histidine, lysine, arginine). The 65 -gliadin fraction is known to be rich in these amino acids (55-60\%) (Wieser, 2001). Considering the literature data and our own results, it can be further noted that there is no clear difference in the total contents of these amino acids present in gliadin and glutenin; i.e. $45-55 \%$ and $44-51 \%$ amino acids with more than one nitrogen atom in the molecule, respectively (Shewry and Halford, 2002; Wieser, 2001). So it still remains unclear why the discrepancy in the $\mathrm{C} / \mathrm{N}$ ratio occurs. One possible explanation lies in the origin, distribution and composition of the protein subfractions present in gluten. For example, the D-type LMW-GS with $40-50 \%$ glutamine contain about $10 \%$ more of this amino acid than the other fractions from gliadin and glutenin with the exception of the $\omega$-gliadin fraction (Shewry and Halford, 2002).

In comparison to the literature data [30-75 kDa (Shewry and Halford, 2002), $55 \mathrm{kDa}$ (van Eckert et al., 2006), 70-40 kDa (Matsuo et al., 2005)] the molecular weight of $\omega 5$ gliadin showed with a mass around $70 \mathrm{kDa}$ (Figure 2a) just one band in the SDS-page gel. In this context, it should be noted that the molecular weights determined by SDSPage are generally liable to be influenced by many factors such as dye binding, migration time, calibration, nature of micelles formed with SDS, extent of glycosylation, etc., and thereby may result in an over-interpretation of the masses calculated (Wieser, 2001). The 61 ,2- fraction found with two major peaks (Figure 2a) between 60 and $80 \mathrm{kDa}$ is also larger than those described in the literature with $45-47$ $\mathrm{kDa}$ (van Eckert et al., 2006). In the $\alpha$-gliadin fraction, the molecular weight of the main fraction lies between 30 and $40 \mathrm{kDa}$ and is conform with the literature (Ferranti et al., 2007; van Eckert et al., 2006). However, other bands with higher molecular weights around 60 and $76 \mathrm{kDa}$ were also observed. Gliadins from the $\gamma$-group showed in contrast to the $\alpha$-gliadins low molecular weight fractions (Figure 2a), but some overlapping was also noted. The reported values are around 30-40 kDa (Ferranti et al., 2007; van Eckert et al., 2006) and so are lower than those observed here. The overlapping of the $\alpha$ - and $\gamma$ - 
gliadins documents the incomplete separation and drawing out of the individual subfractions in this method (van Eckert et al., 2006).

With respect to the separation of the glutenin fractions, the $\omega b$-glutenin (Figure $2 b$ ) showed molecular weights similar to those of the $\omega 1,2$-gliadin fraction, with both having a similar pattern in the SDS-Page. This similarity may have resulted from the evolutionary increase of the genome by the insertion of transposable elements, the formation of duplicate protein genes in the genome, the combination of the genome from different sources or genome rearrangement (Du et al., 2006; Kellogg, 2000). This led in part to the formation of some genes for $\omega$-gliadin in the genome which are tightly linked to those for LMW-GS on the short arm of chromosome one (Gao et al., 2007). These facts and some changes in the amino acid sequence leads to a $\omega$-gliadin-like subunit from the $\omega$-gliadins being present in the glutenin fraction from the D-genome of wheat (Akagawa et al., 2007). The three bands of HMW-GS seem to be also related to the $\omega$-gliadins, because they showed bands that appeared very similar to them (Figure $2 b, c)$. The quantitative biggest fraction of the glutenins detected with RP-HPLC is the LMW-GS. These were also found in the gel with a less intensive signal (Figure 2c). The determined molecular weight corresponds to the literature data, lying between 30 and 45 $\mathrm{kDa}$ (Masci et al., 1998). No bands related to the gliadin fractions were found in the present study, (Figure 2a, b).

\section{Digestion of wheat gluten by Fusarium graminearum protease}

Gliadin degradation after a 4-h incubation with Fusarium proteases was much less affected compared to the glutenin fraction (Figure 3a-d), indicating a preference of the proteases for the latter substrate. This preference for glutenin has also been documented for field trials with naturally and artificially infected samples and could now be verified in the present model system (Eggert et al., in press; Wang et al., 2005). Since the observed differences in the breakdown of the gliadin subfractions as documented in Figure $3 \mathrm{c}$ may be affected by the presence of digested glutenins in this fraction, they will be discussed in the next section of the investigation.

Among the glutenin subfractions, the strongest impact was observed for HMW-GS, underlining the high susceptibility of this fraction to the proteases from $F$. graminearum. These proteases have been reported to be trypsin-like serine proteases that preferentially cut the protein at the lysine or arginine amino-acid side chains. A resemblance to amino peptidase has also been discerned (Pekkarinen et al., 2000; 
Pekkarinen and Jones, 2002; Phalip et al., 2005). Accordingly, the HMW-GS must contain a relatively high quantity of these amino acids. Literature reports have shown a lysine content of between $0.7-1.4 \%$ for HMW-GS and between $0-<1 \%$ for LMW-GS, while equal quantities of arginine (between 1.5 and 2.1\%) are present in both (Masci et al., 1998; Shewry and Halford, 2002; Wieser, 2001). Lysine seems here to be the structural amino acid element responsible for the higher breakdown of HMW-GS in comparison to LMW-GS. This preference for the breakdown of HMW-GS by Fusarium proteases explains also the decreased dough consistence, i.e. the reduced resistance to extension and the loss of dough functionality and loaf volume (Nightingale et al., 1999), because this sub-fraction is responsible for the elastic properties and is positively associated with good bread-making quality (Anjum et al., 2007).

The digestion profile after $24 \mathrm{~h}$ showed a complete absence of the original subfractions in both gliadin and glutenin in comparison to the control (Figure 3a,b).

\section{Digestion of purified gliadin and glutenin by Fusarium graminearum protease}

The degradation of the isolated gliadin fraction showed a stronger destruction of this protein in comparison to the gliadin fraction from gluten (Table 3; Figures 3a,c; 4b,c). These results confirm the hypothesis that besides glutenin digestion, gliadin damage also takes place in infected wheat grains (Eggert et al., in press). This can be corroborated by the increasing formation of gliadin peptides detected after 2, 4 and $8 \mathrm{~h}$ in comparison to the control (Table 2). The breakdown of the gliadins by Fusarium proteases to peptides showed the potential of these proteases to cause a complete degradation of all fractions (Figures 3a; 4b).

Studies on the mechanisms of celiac disease as an inflammatory disorder of the small intestine induced by an immune response after wheat gluten digestion have shown that specific gluten peptides are responsible for the inflammation (Dewar et al., 2004; Koning et al., 2005). If the protease from Fusarium can degrade the gliadin fraction into fragments containing less than ten amino acids, the T-cell stimulation is suppressed and inflammation of the small intestine mucosa can be avoided (Dewar et al., 2004). The problem of toxin formation by the fungus could be avoided by using knockout Fusarium strains with disrupted trichodiene synthase, which would in turn inhibit toxin formation in the medium (Jansen et al., 2005). The direct degradation success of the Fusarium proteases on the gliadin subfractions in comparison to the gliadin fraction from the degraded gluten further documents the eligibility of these enzymes as potential degrading tools (Figure 3c, Table 3). The results further showed that the $\omega 1,2-, \alpha-$ and 
$\gamma$-gliadin fractions were degraded in equal quantities over the different incubation times. This indicates that there seems to be no structural preference for the individual subfractions as substrates.

The degradation of the purified glutenin occurred to a lower extent than the gliadin (Figure 5b, c, Table 3). The fraction which was more soluble in gliadin extraction solution B after the treatment with Fusarium protease, showed an increased extraction yield depending on the incubation time (Table 2, Figure 5d). To our knowledge, this is the first time that such an observation has been recorded. This result gives a new light to the observations made in an earlier study (Wang et al., 2005). The observed effect in the RP-HPLC results could also be confirmed by the detection of two fragments with a molecular weight of 61 and $55 \mathrm{kDa}$ after an 8-h incubation time (Figure 5e). Nevertheless, further experiments (2D-Page, MALDI-TOF-MS) will need to be conducted to analyse this fraction. The intention is to identify low abundant subfractions not yet identified with the methods applied so far. This identification will also provide a better basis for the consequent allocation of the subfractions to the gliadins and/or glutenins.

\section{Conclusions}

Gliadin and glutenin differed in their nitrogen content apparently due to their respective amino acid composition. A clear separation of all gliadin and glutenin fractions was not possible with the application of RP-HPLC and SDS-page. An overlapping effect between the fractions of the specific gluten subfractions took place, thus justifying the need of new multi-dimensional analytical procedures.

In the present study, there was a preference for the digestion of glutenins rather than gliadins during gluten digestion by F. graminearum proteases. Within the glutenin fraction, the HMW-GS sub-fraction was most affected; the effect probably resulting from the preferred specificity of the Fusarium proteases for lysine side chains. Thus, these results partly confirm the trypsin-like serine protease nature of the involved enzymes. The study further documents the eligibility of these enzymes as potential degrading tools.

The isolated digestion of gliadin and glutenin by F. graminearum proteases confirmed the former results; i.e., showed clearly a strong effect on gliadin degradation and appeared to be less effective on glutenin. The formation of a fraction that is more soluble in the gliadin extraction solution after protease treatment was also observed. This finding documents that fragments from the purified glutenin can be falsely 
allocated to the gliadin subfractions and that their amount increases over time during incubation with F. graminearum proteases. Therefore, the allocation of wheat gluten subfractions according to their solubility in different solvents and their conventional analysis per RP-HPLC may lead to false interpretation of results, especially when the wheat grains have been exposed to F. graminearum infection. This also underlines the need for new methods for identification, which will provide a better basis for the consequent allocation of the subfractions to gliadins and/or glutenins. 


\section{References}

Abonyi T., Kiraly I., Tomoskozi S., Baticz O., Guoth A., Gergely S., Scholz E., Lasztity D., Lasztity R. (2007) Synthesis of gluten-forming polypeptides. 1. Biosynthesis of gliadins and glutenin subunits. Journal of Agricultural and Food Chemistry 55:3655-3660.

Akagawa M., Handoyo T., Ishii T., Kumazawa S., Morita N., Suyama K. (2007) Proteomic analysis of wheat flour allergens. Journal of Agricultural and Food Chemistry 55:6863-6870. DOI: $10.1021 /$ jf070843a.

Anjum F.M., Khan M.R., Din A., Saeed M., Pasha I., Arshad M.U. (2007) Wheat gluten: High molecular weight glutenin subunits - Structure, genetics, and relation to dough elasticity. Journal of Food Science 72:R56-R63. DOI: 10.1111/j.1750-3841.2007.00292.x.

Bottalico Antonio P.G. (2002) Toxigenic Fusarium species and mycotoxins associated with head blight in small-grain cereals in Europe. European Journal of Plant Pathology 108:611-624.

Boyacioglu D., Hettiarachchy N.S. (1995) Changes in some biochemical components of wheat grain that was infected with Fusarium graminearum. Journal of Cereal Science 21:57-62.

Dewar D., Pereira S.P., Ciclitira P.J. (2004) The pathogenesis of coeliac disease. International Journal of Biochemistry and Cell Biology 36:17-24. DOI: 10.1016/s1357-2725(03)00239-5.

Du C.G., Swigonova Z., Messing J. (2006) Retrotranspositions in orthologous regions of closely related grass species. Bmc Evolutionary Biology 6:12. DOI: 62 10.1186/1471-2148-6-62.

Eggert K., Wieser H., Pawelzik E. (in press) The influence of Fusarium infection and growing location on protein fractions in emmer (Triticum dicoccum). Journal of Agricultural and Food Chemistry.

Eriksen G.S., Pettersson H. (2004) Toxicological evaluation of trichothecenes in animal feed. Animal Feed Science and Technology 114:205-239.

Ferranti P., Marnone G.R., Picariello G., Addeo F. (2007) Mass spectrometry analysis of gliadins in celiac disease, John Wiley \& Sons Ltd. pp. 1531-1548.

Foroud N.A., Eudes F. (2009) Trichothecenes in cereal grains. International Journal of Molecular Sciences 10:147-173. DOI: 10.3390/ijms10010147.

Gao S.C., Gu Y.Q., Wu J.J., Coleman-Derr D., Huo N.X., Crossman C., Jia J.Z., Zuo Q., Ren Z.L., Anderson O.D., Kong X.Y. (2007) Rapid evolution and complex structural organization in genomic regions harboring multiple prolamin genes in the polyploid wheat genome. Plant Molecular Biology 65:189-203. DOI: 10.1007/s11103-007-9208-1.

Jansen C., von Wettstein D., Schafer W., Kogel K.H., Felk A., Maier F.J. (2005) Infection patterns in barley and wheat spikes inoculated with wild-type and trichodiene synthase gene disrupted Fusarium graminearum. Proceedings of the National Academy of Sciences of the United States of America 102:16892-16897. DOI: 10.1073/pnas.0508467102.

Kellogg E.A. (2000) The grasses: A case study in macroevolution. Annual Review of Ecology and Systematics 31:217-238.

Koning F., Schuppan D., Cerf-Bensussan N., Sollid L.M. (2005) Pathomechanisms in celiac disease. Best Practice \& Research in Clinical Gastroenterology 19:373-387. DOI: 10.1016/j.bpg.2005.02.003.

Laemmli U.K. (1970) Clevage of structural proteins during assembly of head of bacteriophageT4. Nature 227:680-685.

Masci S., D'Ovidio R., Lafiandra D., Kasarda D.D. (1998) Characterization of a low-molecularweight glutenin subunit gene from bread wheat and the corresponding protein that represents a major subunit of the glutenin polymer. Plant Physiology 118:1147-1158.

Matsuo H., Kohno K., Morita E. (2005) Molecular cloning, recombinant expression and IgEbinding epitope of omega-5 gliadin, a major allergen in wheat-dependent exercise-induced anaphylaxis. Febs Journal 272:4431-4438. DOI: 10.1111/j.1742-4658.2005.04858.x.

Nielsen C.C., M. Didier, A. Dietrich, R. Märtlbauer, E. (2009) Trichothecene-induced cytotoxicity on human cell lines. Mycotoxin Research 25:77-84. 
Nightingale M.J., Marchylo B.A., Clear R.M., Dexter J.E., Preston K.R. (1999) Fusarium head blight: Effect of fungal proteases on wheat storage proteins. Cereal Chemistry 76:150-158.

Parry D.W., Jenkinson P., McLeod L. (1995) Fusarium ear blight (SCAB) in small-grain cereals - a Review. Plant Pathology 44:207-238.

Pekkarinen A., Mannonen L., Jones B.L., Niku-Paavola M.L. (2000) Production of proteases by Fusarium species grown on barley grains and in media containing cereal proteins. Journal of Cereal Science 31:253-261.

Pekkarinen A.I., Jones B.L. (2002) Trypsin-like proteinase produced by Fusarium culmorum grown on grain proteins. Journal of Agricultural and Food Chemistry 50:3849-3855.

Phalip V., Delalande F., Carapito C., Goubet F., Hatsch D., Leize-Wagner E., Dupree P., Van Dorsselaer A., Jeltsch J.M. (2005) Diversity of the exoproteome of Fusarium graminearum grown on plant cell wall. Current Genetics 48:366-379.

Shewry P.R. (2009) Wheat. Journal of Experimental Botany 60:1537-1553. DOI: 10.1093/jxb/erp058.

Shewry P.R., Halford N.G. (2002) Cereal seed storage proteins: structures, properties and role in grain utilization. Journal of Experimental Botany 53:947-958.

Thuvander A., Wikman C., Gadhasson I. (1999) In vitro exposure of human lymphocytes to trichothecenes: Individual variation in sensitivity and effects of combined exposure on lymphocyte function. Food and Chemical Toxicology 37:639-648.

van Eckert R., Berghofer E., Ciclitira P.J., Chirdo F., Denery-Papini S., Ellis H.J., Ferranti P., Goodwin P., Immer U., Mamone G., Mendez E., Mothes T., Novalin S., Osman A., Rumbo M., Stern M., Thorell L., Whim A., Wieser H. (2006) Towards a new gliadin reference material isolation and characterisation. Journal of Cereal Science 43:331-341. DOI: 10.1016/j.jcs.2005.12.009.

Wang J.H., Wieser H., Pawelzik E., Weinert J., Keutgen A.J., Wolf G.A. (2005) Impact of the fungal protease produced by Fusarium culmorum on the protein quality and breadmaking properties of winter wheat. European Food Research and Technology 220:552-559.

Wieser H. (2000) Comparative investigations of gluten proteins from different wheat species I. Qualitative and quantitative composition of gluten protein types. European Food Research and Technology 211:262-268.

Wieser H. (2001) 25 Jahre Getreideforschung an der DFA 1975-1999 Deutsche Forschungsanstalt für Lebensmittelchemie, Munich.

Wieser H., Antes S., Seilmeier W. (1998) Quantitative determination of gluten protein types in wheat flour by reversed-phase high-performance liquid chromatography. Cereal Chemistry 75:644-650.

Yazar S., Omurtag G.Z. (2008) Fumonisins, trichothecenes and zearalenone in cereals. International Journal of Molecular Sciences 9:2062-2090. DOI: 10.3390/ijms9112062. 


\title{
5.6 Proteome analysis of Fusarium infection in emmer grains (Triticum dicoccum)
}

\begin{abstract}
Fusarium head blight is a worldwide devastating disease. Pathogen attack on plants results in host-specific biochemical responses which show strategies for the ability of the plant to withstand disease. The fungal infection of emmer grain (Triticum dicoccum) with Fusarium graminearum and Fusarium culmorum was investigated at the level of the proteome. High-resolution two-dimensional gel electrophoresis and mass spectrometry was used to identify proteins that were differentially expressed in response to fungal infection of emmer. Moreover, the influence of natural field conditions of two locations on the carbon and nitrogen content and the mycotoxin concentration of emmer grains were evaluated. Inoculation of emmer with Fusarium leads to infection of the ears with deoxynivalenol concentrations up to $10 \mathrm{mg} \mathrm{kg}^{-1}$ in the grains. Carbon concentrations and crude protein content were not significantly changed, but ten distinct proteins changed in abundance. Stress-related proteins such as peroxidase, peroxiredoxin, and glycosyltransferase increased upon infection, whereas thaumatin and a chitinase decreased. Furthermore, three storage proteins in emmer grains such as $\alpha$ gliadin and two globulins were affected by Fusarium infection. The proteins detected give useful hints for further Fusarium-based resistance breeding and helped elucidate the mechanisms of defence against fungal infection of cereal grains.
\end{abstract}

Keywords: Fusarium head blight, fungal infection, proteome, protease inhibitor, defence proteins, storage proteins

\section{Abbreviations}

2-DE, two-dimensional gel electrophoresis; 3-Ac-DON, 3-acetyl-deoxynivalenol; C, carbon; N, nitrogen; DON, deoxynivalenol; DTT, dithiothreitol; EST, expressed sequence tag; ICC, International Community for Cereal Sciences and Technology;IEF, isoelectric focusing; $\mathrm{kDa}$, kiloDalton, LC, liquid chromatography; MALDI, matrix enhanced laser desorption ionisation; MS, mass spectromtery; NCBI, National Center for Biotechnology; QTLs, quantitative trait loci; SDS, sodium dodecyl sulphate; TOF, time of flight; UDP, uridine diphosphate; 


\section{Introduction}

Fusarium head blight induced by Fusarium spp. is a common disease of food grains such as wheat, maize and barley (Parry et al. 1995; Yazar and Omurtag 2008). The most relevant species in Europe are F. graminearum (teleomorph: Gibberella zeae) and F. culmorum, though the association of a number of other Fusarium species with Fusarium head blight has been documented in the literature (Parry et al. 1995; Foroud and Eudes 2009). The different Fusarium spp. are producers of several mycotoxins such as deoxynivalenol (DON), its precursors 3- and 15-acetyldeoxynivalenol (3-Ac-DON and 15-Ac-DON), and nivalenol, which are all common examples of the B-trichothecenes (Ndong et al. 2002; Yazar and Omurtag 2008; Foroud and Eudes 2009; Radchuk et al. 2009). These mycotoxins cause inappetence, vomiting, diarrhoea and bleeding of the intestines at high doses and can lead to further effects like impairment of immune function in both animals and humans (Yabe et al. 1993; Thuvander et al. 1999; Eriksen and Pettersson 2004). The mycotoxin problem has been addressed in the European Union by establishing the maximum amounts of some Fusarium toxins allowed in products destined for human food [(EG) Nr. 856/2005. 2006] and for animal nutrition [(EG) Nr. 576/2006. 2006]. Moreover, mycotoxins are protein synthesis inhibitors and therefore responsible for proteomic changes (Eriksen and Pettersson 2004).

Emmer (Triticum dicoccum), an ancient tetraploid wheat cultivar, is primarily grown in organic farming systems (Islam et al. 2003; Shewry 2009). At the moment, there is little specific knowledge about the influence of a Fusarium infection on the protein pattern of emmer grains (Bhadauria et al. 2010). However, there are some data available for soft wheat (Triticum aestivum) which suggest that no or just a marginal impact on the crude protein content could be observed depending on the degree of infection (Boyacioglu and Hettiarachchy 1995; Wang et al. 2005a). Nevertheless, by means of HPLC, it has been shown that storage proteins (mainly gliadins and glutenins) are influenced by Fusarium infection. The infection was associated with an increase in the gliadin fraction together with reduced glutenin quantities (Wang J.H. et al. 2005). Such changes were recently also found to occur in emmer (Wang et al. 2005a; Eggert et al. 2010,). An explanation for this reduction of gluten proteins is still absent. It is not known if the storage protein synthesis during grain maturation is different for gliadin and glutenin formation because only a belated polymerization of glutenin has been reported in the literature (Abonyi et al. 2007). A decrease in glutenins might be based on the degradation of a specific 
glutenin fraction caused by Fusarium proteases or its mycotoxins which accumulate in the plant tissue and inhibit protein biosynthesis (Eriksen and Pettersson 2004).

Different expressions of proteins in response to fungal interaction might be correlated to the defence strategies of a plant. The results of such defence responses include, for example, changes in secondary metabolism (Dixon 2001) or induction of proteins such as enzymes and enzyme inhibitors (Pekkarinen et al. 2007). So far, with the exception of storage protein fractions, only a few data concerning the interaction between Fusarium spp. and emmer at the level of distinct proteins are available. A former study focusing on germinating maize and Fusarium verticillioides showed an induction of antioxidative enzymes (such as superoxide dismutase, gluthatione S-transferase, and catalase) which protect plants from antioxidative stress. Moreover, proteins involved in protein synthesis control, such as heat shock proteins, were found to be up-regulated. Additionally, some enzymes involved in carbon metabolism were down-regulated in response to the fungal infection (Campo et al. 2004). Another study based on wheat spikes infected by F. graminearum analysed after a period of 6 to 24 hours reported a decrease in proteins involved in carbon metabolism and photosynthesis. Only some proteins which were directly related to stress response and defence were found to be upregulated, such as methyl transferase, a heat shock protein, a jacaline-like protein, and a beta-glucosidase (Wang et al., 2007). Similar effects after a direct infection of wheat spikelets with F. graminearum conidospores at mid-anthesis were obtained by Zhou and his colleagues (Zhou et al. 2005; Zhou et al. 2006). Two major groups of proteins which responded to Fusarium graminearum infection were identified, one group with a potential function related to oxidative burst, signalling and pathogenesis-related proteins (PR proteins) and a another group which is involved in $\mathrm{C}$ and $\mathrm{N}$ metabolism. It could be concluded, therefore, that the amino acid synthesis and $\mathrm{N}$ metabolism of the host were triggered by the influence of F. graminearum (Zhou et al. 2005; Zhou et al. 2006). Similar effects like induced oxidative burst, oxidative stress response and pathogenesisrelated response were reported in a study with barley cultivars, in which the infected heads were harvested after three days (Geddes et al. 2008). Additionally, there was a strong increase in PR proteins in the low-susceptible barley genotypes, as well as a strong response of an oxidative burst and a de novo expression of a chitinase. This showed that there were differences in pathogenesis response between cultivars with different degrees of sensitivity (Geddes et al. 2008). 
Despite all this work, the resistance potential of the ancient species emmer to fungal infection is still unclear. The impact of a fungal infection on emmer accompanied by mycotoxin production especially at the level of grain proteome is largely unknown (Shewry 2009). Previous studies have only described the investigation of short-term treatment after infection or did not include an evaluation of the infection degree; nor did they consider the effects on emmer's proteome (Zhou et al. 2005; Zhou et al. 2006; Wang et al. 2007; Geddes et al. 2008). The present study evaluated the proteome in ripe emmer grains after natural and artificial plant infection with Fusarium spp. under field conditions. The infection success was, therefore, for the first time in an investigation like this, defined by the mycotoxin content. In addition, the F. graminearum proteome was used to evaluate the impact of the fungal influence in strongly infected emmer grains.

\section{Material and Methods}

\section{Experimental design and sample preparation}

The emmer cultivar Linie 9-102 was grown in two field trials at the locations Reinshof and Sattenhausen near Göttingen (Germany). The conditions at the location Reinshof were: $152 \mathrm{~m}$ above sea level, wind-sheltered and dale area near a river. The $\mathrm{N}_{\min }$ content was $145 \mathrm{~kg} \mathrm{ha}^{-1}$ recorded in $90 \mathrm{~cm}$ dry soil. The conditions at Sattenhausen were $260 \mathrm{~m}$ above sea level, hilly and windy area. The $\mathrm{N}_{\min }$ content was $95 \mathrm{~kg} \mathrm{ha}^{-1}$ in $90 \mathrm{~cm}$ dry soil; an additional fertilization with $40 \mathrm{~kg} \mathrm{~N} \mathrm{ha}^{-1}$ was conducted two months after sowing.

The plots were randomized with eight replications each. The second row of each block was artificially inoculated with a mixed F. culmorum plus F. graminearum spore suspension $\left(50 \mathrm{ml} \mathrm{m}^{-2} ; 1 \times 10^{5}\right.$ spores $\left.\mathrm{ml}^{-1}\right)$ three times during flowering. For production of the predominant fusaric fungal on grains, F. graminearum, fungal conidiospores (FG142; FG143; FG144) were grown for nine days at $23^{\circ} \mathrm{C}$ in an autoclaved $(15 \mathrm{~min}$, $121^{\circ} \mathrm{C}$ ) cultural medium (Czapek-Dox, Merck Chemicals, Germany). After this time, the fungus was separated from the media, freeze dried and homogenized under liquid nitrogen. Three DON-producing strains of F. culmorum (FC34, FC35, FC36) and F. graminearum (FG142; FG143; FG144) were used for conidiospore production. After harvest, the grain without inoculation (natural infection) and grain with inoculation (artificial infection) of the plots (four replicates each) from every field trial were pooled together. Whole-grain flour was obtained by milling (Retsch ZM 100, Haan, Germany) to a particle size of $0.5 \mathrm{~mm}$. 
LC-MS/MS of deoxynivalenol (DON) and 3-acetyl-deoxynivalenol (3-Ac-DON)

Whole-grain flour $(5 \mathrm{~g})$ was extracted with a $40 \mathrm{ml}$ acetonitril-water mixture (80:20) and shaken over night on a reciprocal shaker. The extracts were then centrifuged for 12 min at 5,000 $\times \mathrm{g}$ and $4 \mathrm{ml}$ of the supernatant were used for solid-phase extraction (Bond-Elut Mycotoxin, Varian GmbH, Darmstadt, Germany) according to the instructions of the manufacturer. Two $\mathrm{ml}$ of the clean extract were evaporated to dryness in a vacuum, redissolved in $200 \mu$ of methanol-water (50:50) with $0.2 \mathrm{mmol}$ ammonium acetate and $10 \mu \mathrm{l}$ were injected into a C18 column $(100 \times 2 \mathrm{~mm}, 3 \mu \mathrm{m}$ particle size) filled with polar-modified material (Polaris Ether, Varian $\mathrm{GmbH}$, Darmstadt, Germany). The analytes were eluted with a methanol-water gradient ( $15 \%$ to $70 \%$ for $20 \mathrm{~min}$ ) containing $0.2 \mathrm{mmol}$ ammonium acetate at a flow rate of $0.2 \mathrm{ml} / \mathrm{min}$. DON and 3-Ac-DON were detected by tandem mass spectrometry as described previously (Adejumo et al. 2007).

\section{Quantitative nitrogen analysis}

The nitrogen content was quantitatively measured with a $\mathrm{C} / \mathrm{N}$-analyser (Vario MAX CN Elementar Analyse system GmbH, Hanau, Germany). The N content of a 100-mg dried whole grain flour sample from each proband was analysed and converted into protein by using the factor 5.7 for emmer and 6.25 for Fusarium (ICC No. 105/2).

\section{Protein extraction for $2 \mathrm{D}$ proteomics}

Emmer grain proteins for isoelectric focusing were prepared from dried whole-grain flour using a DTT-TCA-acetone precipitation method (Zorb et al. 2004). A volume of $1.6 \mathrm{ml} \mathrm{10 \%} \mathrm{TCA} \mathrm{in} \mathrm{acetone} \mathrm{plus} 50 \mathrm{mmol}$ DTT was added to $50 \mathrm{mg}$ dried whole-grain flour. After vigorous shaking, the samples were incubated for $10 \mathrm{~min}$ in an ice-cold ultrasonic bath, and subsequently incubated for a minimum of $1 \mathrm{~h}$ or overnight at $-20^{\circ} \mathrm{C}$ before centrifugation $\left(20,000 \times \mathrm{g}, 15 \mathrm{~min}, 4^{\circ} \mathrm{C}\right)$. After discarding the supernatant, the precipitant was resuspended in $1.5 \mathrm{ml}$ ice-cold solution (50 mmol DTT; 2 mmol EDTA in acetone). The samples were then incubated for $15 \mathrm{~min}$ in an ice-cold ultrasonic bath and subsequently incubated for $1 \mathrm{~h}$ (minimum) or overnight at $-20^{\circ} \mathrm{C}$ before centrifugation $\left(20,000 \times \mathrm{g}, 15 \mathrm{~min}, 4^{\circ} \mathrm{C}\right)$ and discarding the supernatant. The procedure was repeated and the precipitated proteins were lyophilised under $\mathrm{N}_{2}$. Then the pellets were resuspended in $800 \mu$ protein sample buffer [8 $\mathrm{M}$ urea; $2 \mathrm{M}$ thiourea; $0.5 \%$ pharmalyte buffer (v/v, pH 3-10); 4\% (w/v) CHAPS; 30 mmol DTT; 20 mmol Tris, $\mathrm{pH}$ $8.8 ; 5 \mathrm{mmol}$ Pefablock]. For protein solubilisation, the samples were vortexed and 
incubated for $2 \mathrm{~h}$ at $33^{\circ} \mathrm{C}$ followed by a 10-min incubation in an ultrasonic bath. The samples were then centrifuged $(18,000 \times \mathrm{g}, 30 \mathrm{~min})$ and the resulting supernatant was subjected to isoelectric focusing. The protein concentrations were determined using a 2D QUANT protein determination kit (GE Healthcare, Munich, Germany).

Isoelectric focusing (IEF) and 2-DE

Two-dimensional gel electrophoresis (2-DE) with some modifications was performed using protocols from Görg \& Weiss (Gorg et al., 2000). Commercially purchased IPG strips (18 cm, pH 3-10, linear; GE Healthcare, Munich, Germany) were used. The trays were loaded with $400 \mu \mathrm{g}$ protein diluted in $345 \mu$ protein sample buffer plus $5 \mu \mathrm{l}$ bromphenol blue $(10 \mathrm{mg} / \mathrm{ml})$ in $0.25 \mathrm{~mol}$ Tris-buffer $\mathrm{pH}$ 7. The strips were rehydrated for $11 \mathrm{~h}$. Filter papers (Whatman) soaked with 0.5 mol DTT were placed at the acidic and basic sides of the strip to prevent renaturation of the proteins. Finally, the strips were covered with paraffin oil to prevent evaporation. IEF was carried out in a Multiphor apparatus (GE Healthcare, Munich, Germany) according to the following conditions: 1 h 20-200 V; 1 h 200-500 V; 1 h 500-1000 V; 2 h 1000-4000 V and 3 h 4000-8000 V. The system temperature was $20^{\circ} \mathrm{C}$ and the current was set to $45 \mu \mathrm{A}$ per strip.

To run the second dimension, the strips were placed in equilibration buffer [50 $\mathrm{mM}$ Tris-HCl, $\mathrm{pH} 8.8 ; 6 \mathrm{mM}$ urea; 30\% (v/v) glycerol, 2\% (w/v) SDS; 0.001\% (w/v) bromophenol blue] containing 1\% (w/v) DTT and gently agitated for $10 \mathrm{~min}$. The strips were incubated again for $10 \mathrm{~min}$ in equilibration buffer containing $4 \%(\mathrm{w} / \mathrm{v})$ iodoacetamide instead of DTT under gentle agitation and rinsed three times with SDSPAGE running buffer [25mM Tris; $192 \mathrm{mM}$ glycine; 0.1\% (w/v) SDS]. SDS-PAGE was performed by using $12.5 \%$ (w/v) acrylamide $20 \mathrm{~cm}$ x $20 \mathrm{~cm}$ gels. Molecular weight standards from 10 to $150 \mathrm{kDa}$ were used (Sigma, Germany). The gels were fixed with $50 \%(\mathrm{v} / \mathrm{v})$ ethanol and 12\% (v/v) acetic acid and stained with Coomassie R 250.

Data analyses

All the gels were scanned with an image scanner (HP Scan-Jet 4890, USA; 300 dpi and 16 bits per pixel). A computer-assisted 2-DE analysis was performed using Delta 2D 3.4 software (Decodon GmbH, Greifswald, Germany). The statistical calculations were based on the naturally and artificially infected samples from the two locations. The flour samples per location were replicated three times. Average gels were created for each biological replication. A spot filter with an intensity limit of 0.02 for each spot was 
applied. By doing this, weak spots as well as any artificial speckles were eliminated in all 2-DE gels. For the detection of protein spots that proved to be different between the treatments, a final filter was introduced; the resulting proteins differed by at least $50 \%$ between both treatments.

\section{Protein identification}

Mass spectrometry and protein identification of selected emmer protein spots with nanoLC-MS/MS for peptide mass fingerprint and de novo sequencing were performed at the OMX GmbH, D-82234 Wessling, Germany (http://www.omx-online.com) (Granvogl et al., 2007). MALDI-TOF-based identification of the total emmer gel and the F. graminearum gel were performed at the Center for Molecular Medicine, University of Cologne, Germany. The isolation, digestion and preparation of the MALDI targets were carried out on the Proteineer dp and sp robot (Bruker Daltonics, Bremen, Germany). An automatic acquisition of MALDI-TOF MS spectra was performed on a Bruker Reflex IV MALDI-TOF mass spectrometer controlled by FlexControl 1.3 software (Bruker Daltonics, Bremen, Germany).

Briefly, all spectra were acquired in the positive ion mode in 20 acquisition cycles using an external calibration. In each cycle, five shots were stored in the temporal acquisition buffer for software-driven evaluation. Spectra with a minimum signal-to-noise ratio of ten and a minimum resolution of 4500 for the most intense peak in the mass range from $\mathrm{m} / \mathrm{z} 1200$ to $\mathrm{m} / \mathrm{z} 3000$ were added to the sum. Raw spectra were processed by Flexanalysis 2022.4 and the generated peak lists were transferred to Proteinscape 1.3, which triggered database searches in NCBI release 20081017 using MASCOT 1.9. The database search was restricted to green plants and trypsin specificity with no missing cleavage site allowed. Maximum mass error was $30 \mathrm{ppm}$ for externally calibrated spectra. The state of cysteine was set to carbamidomethyl; optional oxidation of methionine was allowed.

For the sake of easy reading, the term "protein" was used when referring to a spot on 2DE gels. The molecular weight of the protein spots was calculated using the standard 10 $\mathrm{kDa}$ ladder applied to the gels. The $\mathrm{pI}$ of the protein spots was calculated from their position on the IEF strips as mentioned in the manufacturer's specifications (GE Healthcare, Munich, Germany). Therefore, the availability of only ESTs and partial genome sequence data hampered a comprehensive identification of all affected proteins. Subsequent protein identification was achieved by using UniProtKB (http://www.uniprot.org/uniprot/). 


\section{Results}

DON and 3-Ac-DON formation in naturally and artificially infected emmer grains

The toxin concentrations were in the range of 0.4-10.9 $\mathrm{mg} \mathrm{kg}^{-1}$ (Table 1). The artificial infection generally led to higher toxin concentrations compared to the natural infection. In comparison of the artificially and the naturally infected emmer grains, the Fusarium toxins DON and 3-Ac-DON showed a sevenfold increase at the location Sattenhausen and a sixfold increase at Reinshof. The total toxin concentrations in the grains from Reinshof were four times higher than those from Sattenhausen. As indicated by the toxin concentrations, the grains grown at Reinshof had a higher degree of Fusarium infection.

Carbon (C), nitrogen $(N)$ and total protein content in naturally and artificially infected emmer samples and in F. graminearum

The concentrations of $\mathrm{C}$ and $\mathrm{N}$ in emmer grain changed only slightly when infected with Fusarium (Table 1). Comparing both locations, a difference of only $0.4 \%$ for the $\mathrm{C}$ concentration with a slightly changed $\mathrm{N}$ concentration $(0.8 \%)$ was detected. This resulted in a higher $\mathrm{C} / \mathrm{N}$ ratio at Sattenhausen. The higher $\mathrm{N}$ concentration in the grains at Reinshof might have been caused by the higher soil $\mathrm{N}$ availability as indicated by the $35 \%$ higher $\mathrm{N}_{\min }$ values for this location (see Materials and Methods). As a result, the grains from Reinshof contained a higher amount of $\mathrm{N}$ and therefore higher crude protein content than those from Sattenhausen. No significant impact of the infection of $F$. culmorum and F. graminearum on the total protein content in any of the samples was detected. 
Table 1 DON plus 3-Ac-DON concentrations as toxin ( $\mathrm{mg} \mathrm{kg}^{-1}$ whole-grain flour) of naturally and artificially infected emmer grains from the locations Sattenhausen and Reinshof. Carbon $(\mathrm{C})$, nitrogen $(\mathrm{N})$ and crude protein content of naturally and artificially infected emmer grains (protein, factor, 5.7; ICC No. 105/2) and Fusarium graminearum (protein, factor 6.25; ICC No. 105/2)

\begin{tabular}{|c|c|c|c|c|c|c|}
\hline Location & Parameter $^{\#}$ & \multicolumn{2}{|c|}{ Natural infection } & \multicolumn{3}{|c|}{ Artificial infection } \\
\hline \multirow[t]{5}{*}{ Sattenhausen } & Toxin $\left(\mathrm{mg} \mathrm{kg}^{-1}\right)$ & 0.4 & \pm 0.0 & 2.8 & \pm & 0.7 \\
\hline & $\mathrm{C}(\%)$ & \multicolumn{2}{|c|}{47.9} & \multicolumn{3}{|c|}{47.7} \\
\hline & $\mathrm{N}(\%)$ & \multicolumn{2}{|c|}{2.8} & \multicolumn{3}{|c|}{2.7} \\
\hline & $\mathrm{C} / \mathrm{N}$ ratio & \multicolumn{2}{|c|}{17.1} & \multicolumn{3}{|c|}{17.7} \\
\hline & Protein $(\%)$ & \multicolumn{2}{|c|}{16.0} & \multicolumn{3}{|c|}{15.4} \\
\hline \multirow[t]{5}{*}{ Reinshof } & Toxin $\left(\mathrm{mg} \mathrm{kg}^{-1}\right)$ & 1.8 & \pm 0.2 & 10.9 & \pm & 0.5 \\
\hline & $\mathrm{C}(\%)$ & & & \multicolumn{3}{|c|}{48.2} \\
\hline & $\mathrm{N}(\%)$ & & & \multicolumn{3}{|c|}{3.7} \\
\hline & $\mathrm{C} / \mathrm{N}$ ratio & & & \multicolumn{3}{|c|}{13.0} \\
\hline & Protein $(\%)$ & & & \multicolumn{3}{|c|}{21.1} \\
\hline \multirow{4}{*}{$\begin{array}{c}\text { Fusarium } \\
\text { graminearum }\end{array}$} & $\mathrm{C}(\%)$ & \multicolumn{5}{|c|}{56.8} \\
\hline & $\mathrm{N}(\%)$ & \multicolumn{5}{|c|}{3.1} \\
\hline & $\mathrm{C} / \mathrm{N}$ ratio & \multicolumn{5}{|c|}{18.3} \\
\hline & Protein $(\%)$ & \multicolumn{5}{|c|}{19.4} \\
\hline
\end{tabular}

\# Parameters based on dry matter content of whole-grain flour

The crude protein content of the Fusarium fungus itself was $19.4 \%$ based on dry matter. The fungal total $\mathrm{N}$ and $\mathrm{C}$ concentrations were about 10 to $11 \%$ higher than in emmer.

\section{Proteome}

We detected 890 protein spots on 2D gels of F. graminearum which was in the range of other reports (Taylor et al. 2008). A comparison of the F. graminearum proteome with the emmer proteome was not possible because no strict congruity of the $2 \mathrm{D}$ protein pattern could be found. Unfortunately, the pattern of both proteomes differed too much for creating an overlay of the 2D gels. 


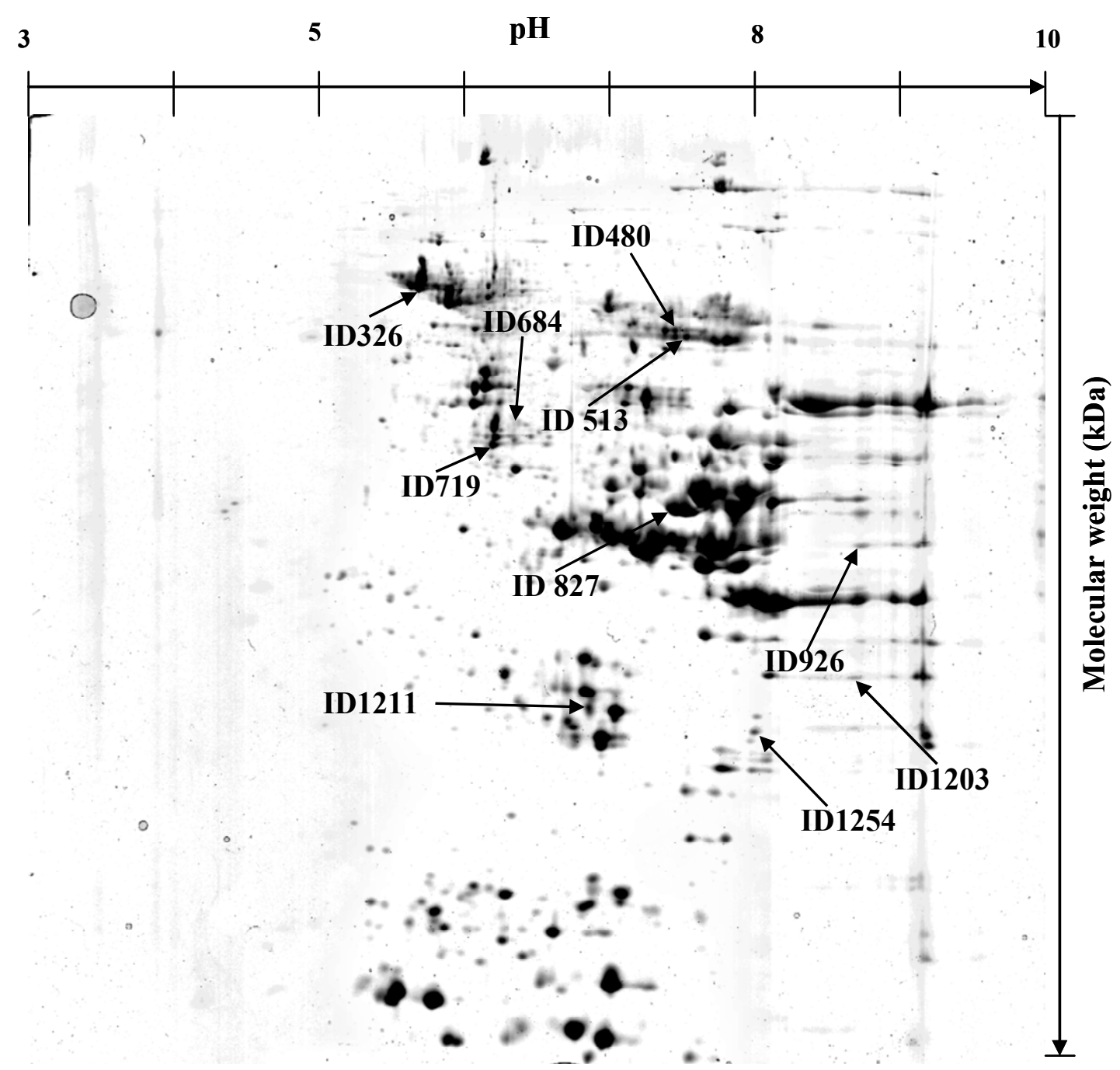

Figure 1 Two-dimensional protein gel of emmer grains infected with Fusarium ssp. (12\% SDS-PAGE, IEP range, $\mathrm{pH}$ 3-10, $18 \mathrm{~cm}$, linear strip; Coomassie R250 staining). Changed protein spots are marked with arrows and ID numbered according to Table 2 (ID362 ß-amylase, ID480 globulin-3, ID513 globulin-2, ID 684 glycosyltransferase, ID719 serpin, ID827 $\alpha$-gliadin, ID926 peroxidase I, ID1203 class II chitinase, ID1211 thioredoxin peroxidase, ID1254 thaumatin like protein).

Protein extraction from the dry emmer whole-grain flour was successful. A subsequent analysis of the proteins on 2D gels led to a detection of 314 protein spots in the artificially infected and 412 proteins in the naturally infected grains. After conservative statistical evaluation of all the spots and calculation of the ratio of the artificial infection and natural infection only ten protein spots were reliably detected as being changed by a factor greater than two. These ten protein spots were than identified using MALDITOF-MS or nanoLC-MS/MS (Figure 1; Table 2). The nanoLC-MS/MS data led to a $100 \%$ sequence coverage of two to six peptides and all Mascot Scores of the MALDI- 
TOF-MS identification were higher than 74.1. The five with MALDI-TOF-MS identified protein spots had either higher or lower concentrations under artificial infection conditions (Table 2). 
Table 2 Compilation of information about ten proteins changed in abundance upon infection with Fusarium spp. in emmer grains. Ratio (relative units) based on differences in proteins from naturally and artificially infected grains as detected by two-dimensional gel electrophoresis (see Materials and Methods). Identification of proteins by (a) sequence coverage was 100\%; Mascot score: identification using nanoLC-MS/MS denovo-synthesis and with MALDI-TOF-MS (see Materials and Methods). Spot ID see Figure 1

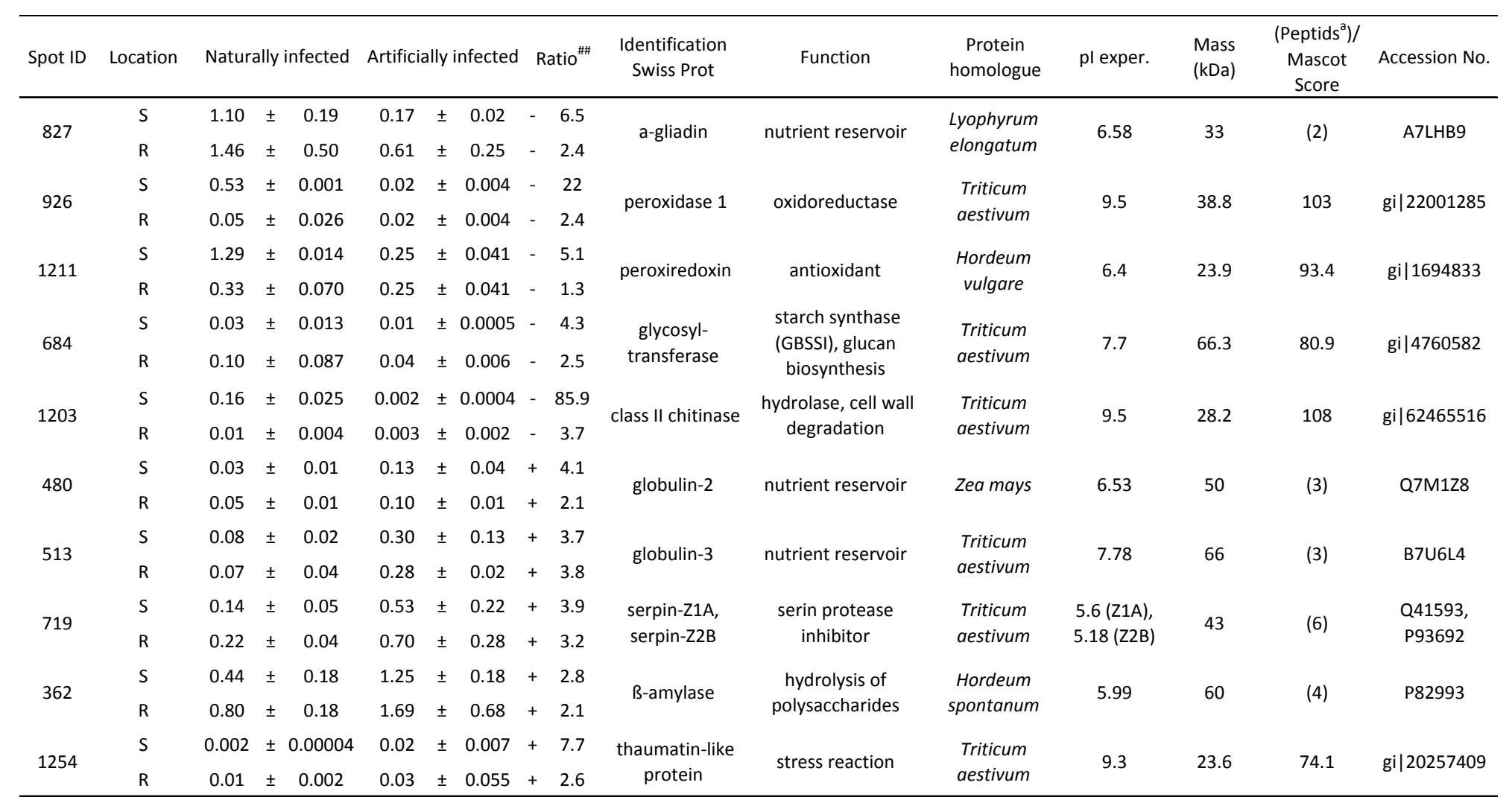

\footnotetext{
\#\# Ratios based on: (-) down-regulated; (+) up-regulated; pI: isoelectric point, S: Sattenhausen, R: Reinshof
} 
Proteins down-regulated under infection: A sulphur-rich storage protein namely $\alpha$ gliadin was down-regulated after artificial infection of emmer (Table 2, Figure 1; ID 827) (Shewry and Halford 2002; Shewry 2009). In the grains from Sattenhausen, the $\alpha$ gliadin was reduced by a factor of 6.5 . A positive influence by the higher $\mathrm{N}$ availability at Reinshof might have been responsible for a lower reduction of the $\alpha$-gliadin concentration.

After infection, a peroxidase I was down-regulated in the grains from both locations by a factor of 22 at Sattenhausen and a factor of 2.4 at Reinshof (Table 2, Figure 1; ID 926). A peroxiredoxin was also found to be reduced by a factor of maximal 6.5 in grains at Sattenhausen under artificial infection (Table 2, Figure 1; ID 1211). Peroxiredoxins are a family of small peroxidases with individual roles in cellular redox regulation and antioxidant protection (Tripathi et al., 2009).

In addition, a glycosyltransferase was down-regulated by a factor of 4.3 in the grains from Sattenhausen (Table 2, Figure 1; ID 684). These enzymes catalyse the glycosylation of radicals to an acceptor molecule usually to an alcohol (Lemmens et al. 2005; Lulin et al. 2010). This glycosylation reaction is important for the biosynthesis of diverse glycoproteins.

Next, a class II chitinase was identified (Table 2b; Figure 1; ID1203). Chitinases are digestive enzymes that break down glycosidic bonds in chitin from fungal cell walls (Caruso et al. 1999). Our results show a reduction in chitinase protein quantity after infection by a factor of 3.7 in the grains from Reinshof and there were negligible amounts of this protein spot in the grains from Sattenhausen.

Proteins up-regulated under infection: At both locations, the artificial infection of emmer by Fusarium resulted in the up-regulation of a globulin-2 and globulin-3 by a factor of 2.1 and 4.1, respectively (Table 2; Figure 1; ID480, ID513). Both globulins were members of the storage protein pool of emmer (Shewry and Halford 2002; Altenbach et al. 2009). Two serine protease inhibitors were identified originating from one 2D spot, namely serpin-Z1A and serpin-Z2B, which together were induced threeand fourfold after artificial infection at both locations (Table 1, 2a; Figure 1; ID719). Both serpins had a similar molecular weight (MW) and shared $94.7 \%$ sequence homology (Roberts and Hejgaard 2008).

Next, an endosperm $ß$-amylase was identified as being up-regulated after infection by the factor of 2.1 and 2.8 at both locations (Table 2a, Figure 1 ID362). B-amylase is an enzyme with high abundance in grain that breaks starch from the endosperm down into 
sugar (Campo et al. 2004). Lastly, a cold-stress-induced protein, namely a thaumatinlike protein (Table 2b; Figure 1; ID 1254), was induced by a factor of 2.6 to 7.7 at both locations after infection. Several members of the thaumatin protein family display significant inhibition of hyphal growth and sporulation in various fungi. Thaumatins are considered to be PR proteins (Kuwabara et al. 2002).

\begin{tabular}{|c|c|c|c|}
\hline Spot ID & Protein & $\begin{array}{l}\text { Naturally } \\
\text { infected }\end{array}$ & $\begin{array}{l}\text { Artificially } \\
\text { infected }\end{array}$ \\
\hline 827 & $\alpha$-gliadin & & \\
\hline 926 & peroxidase 1 & & $\theta$ \\
\hline 1211 & peroxiredoxin & & \\
\hline 684 & glycosyltransferase & & \\
\hline 1203 & class II chitinase & & \\
\hline 480 & globulin-2 & & \\
\hline 513 & globulin-3 & & \\
\hline 719 & $\begin{array}{c}\text { serpin-Z1A, } \\
\text { serpin-Z2B }\end{array}$ & & \\
\hline 362 & B-amylase & & \\
\hline 1254 & thaumatin-like protein & & \\
\hline
\end{tabular}

Figure 2 In zoomed Coomassie-stained protein spots from 2D gels of naturally and artificially infected emmer which were changed by a factor greater than two. Spot numbers according to Table 2 (ID362 ß-amylase, ID480 globulin-3, ID513 globulin-2, ID 684 glycosyltransferase, ID719 serpin, ID827 $\alpha$-gliadin, ID926 peroxidase I, ID1203 class II chitinase, ID1211 thioredoxin peroxidase, ID1254 thaumatin like protein). 


\section{Discussion}

DON and 3-Ac-DON formation in naturally and artificially infected emmer grains

Fusarium head blight is a serious disease of small grain cereals. This grain disease does not only cause yield loss, but more seriously has the ability to deteriorate seed quality by contamination of the infected grains with trichothecene toxins, which in turn may alter the protein biosynthesis. DON is one of the most important of these toxins. It was proposed that DON acts first as a virulence factor during fungal pathogenesis and then accumulates to high levels in wheat grain (Lulin et al., 2010). Toxin concentrations (DON and 3-Ac-DON) in emmer were found in concentrations comparable to those found in soft wheat (Beyer et al. 2006), showing that the emmer investigated here was also highly susceptible to the two Fusarium spp. used. The artificial infection led to a sevenfold higher mycotoxin concentration than in the naturally infected grains.

Additionally, a clear influence of the location was detected. The more sheltered conditions with less wind and higher humidity at Reinshof led to a higher toxin concentration and subsequently to a higher degree of infection in both the naturally and artificially infected samples (Table 1). These findings are in good accordance with former reports which confirmed the susceptibility of emmer to Fusarium (Buerstmayr et al. 2003; Oliver et al. 2007).

Carbon $(C)$ and nitrogen $(N)$ concentrations and crude protein content in naturally and artificially infected emmer grains and in F. graminearum

Nitrogen availability of plants, especially at the grain-filling phase, leads to higher $\mathrm{N}$ and crude protein concentrations in cereal grains (Jahn-Deesbach et al. 1970). The higher $\mathrm{N}$ and protein concentrations in grains obtained from Reinshof might be a consequence of the higher $\mathrm{N}$ availability in the soil as indicated by the higher $\mathrm{N}_{\min }$ values found there. The higher concentrations of $\mathrm{N}$ with nearly unchanged $\mathrm{C}$ concentrations, therefore, led to a lower $\mathrm{C} / \mathrm{N}$ ratio in the grains from Reinshof. In addition to mycotoxin concentrations, a high $\mathrm{N}$ availability is another promoting factor for gene expression and might also be responsible for a higher storage protein generation in cereals (Shewry \& Halford 2002). An effect of the higher $\mathrm{N}$ concentrations on the $\mathrm{C}$ fractions was not detectable because the $\mathrm{C}$ concentrations did not change (Table 1). 


\section{Proteomics}

Comparing the artificially infected emmer grains with the naturally infected grains, a set of 10 proteins were changed in abundance as detected by the use of the 2D gels (Figure 1). The down-regulation of five proteins might be due, on the one hand, to the plant proteins being possibly degraded by the fungal proteases or on the other hand, to a reduced vitality of the plant after infection with Fusarium (Table 1). Additionally, increasing mycotoxin concentrations in the plant tissue may lead to negative effects causing decreased protein synthesis or protein decay (Eriksen and Pettersson 2004).

After infection, five proteins were found in higher concentrations. It has been shown that proteins with a function related to oxidative burst, signalling, and PR proteins increase under stress conditions (Zhou et al. 2006; Wang et al. 2007), therefore it might be argued that these five proteins may have such a function.

Only few storage proteins in the emmer grains were visibly affected by the fungal infection in this investigation. A reduction of $\alpha$-gliadin (ID 827) after infection with Fusarium at both locations indicates a reduced pool of sulphur-rich storage proteins in emmer. The fungal activity may lead to a reduction of these nutritionally valuable Nand S-rich proteinaceous storage components of the grain. In contrast, the expression of the storage protein components globulin 2 and 3 (ID 480; 513) were induced three- to fourfold after infection. Globulins are expressed at a late phase of grain development (Altenbach et al. 2009) and their amount depends on the $\mathrm{N}$ availability of the plant (Shewry and Halford 2002). The induction of the globulins was not explainable by the different $\mathrm{N}$ levels at both sites because the globulins in the grains from Reinshof were not higher. The fungal infection, therefore, was directly responsible for the enhanced expression of the globulins in a late phase of grain development. The increase in globulins might serve as compensation for reduced $\alpha$-gliadin content in the grain after Fusarium infection. A recent report on barley grains also did not find any considerable change in the total storage protein fraction in response to Fusarium infection (Yang et al. 2010).

Our data show that in ancient emmer an infection of Fusarium leads to the induction of endogenous serine-protease inhibitors serpin-Z1A and serpin-Z2B (Table 2, Figure 1, Figure 2). Serpins (ID 719) not only function as serine proteinase inhibitors, they are also part of the storage protein component of the grain (Roberts et al. 2003). In wheat, a short-term infection by Fusarium $(6 \mathrm{~h}-3 \mathrm{~d})$ did not lead to an induction of wheat serpins (Roberts and Hejgaard, 2008), which implies that only a long-term infection 
leads to enhanced serpin expression during the kernel development, as seen in this study. The inhibition of fungal proteinases by the endogenous emmer protease inhibitor serpin may prevent to a certain degree the digestion of seed storage proteins after fungal infection (Phalip et al. 2005; Pekkarinen et al. 2007). Further studies are needed to evaluate the role of serpins in fungal resistance.

Another stress-inducible protein, namely thaumatin-like protein (Table 2, Figure 2; ID 1254), was induced by a factor of up to 7.7 after fungal infection. Thaumatin-like proteins are PR proteins whose antifungal activity leads to reduced hyphal growth (Kuwabara et al. 2002). At field level, the artificial infection of emmer led to a physiological reaction which increased the expression of PR proteins up to eightfold. The up-regulation of pathogen-related genes in the ears might be an important part of the protection mechanism of emmer against fungal infection.

We also detected a down-regulation of a class II chitinase (ID 1203) by a factor of 3.7 in grains from Reinshof and an almost total reduction of this enzyme in grains from Sattenhausen after infection (Table 2, Figure 2). This decrease in class II chitinase may have been induced by a fungal signal which leads to lower chitinase concentrations in emmer. In contrast to emmer, former investigations in modern soft wheat and barley detected the induction of a chitinase after infection with Fusarium (Caruso et al. 1999; Geddes et al. 2008). Furthermore, transgenic wheat expressing a barley class II chitinase exhibited enhanced resistance against F. graminearum (Shin et al. 2008).

In the present study, the down-regulation of a UDP-glucosyltransferase was detected in the grains after Fusarium infection. UDP-glucosyltransferase is known to be related to DON resistance in wheat. The major QTLs contributing to DON resistance have been identified and it is probably achieved by encoding or regulating UDPglucosyltransferases (Lemmens et al. 2005; Lulin et al. 2010).

Enzymes that play a role in protecting the cell from oxidative damage are also important for fungal-induced stress phenomena in plant tissues. Peroxiredoxins and peroxidases are known to play important roles in combating the reactive oxygen species generated at the level of electron transport activities in the plant exposed to biotic stress (Neumann et al. 2009; Tripathi et al. 2009). In addition, peroxiredoxins also modulate redox signalling during development and adaptation (Tripathi et al. 2009). We found two such enzymes down-regulated after artificial Fusarium infection, namely peroxidase I (ID 926) and peroxiredoxin (ID 1203) by factors of two- to fivefold in ripe grains (Table 1). These results are in contrast to earlier studies which found the induction of enzymes that 
play an antioxidative role in the cell (Caruso et al. 1999; Campo et al. 2004; Geddes et al. 2008). However, these studies were performed with a short-term infection of a maximum of four days. This down-regulation of peroxidase I and peroxiredoxin in the present study maybe based on changes in the importance of the defence proteins; for example, in early kernel development, peroxidases are important for defence while in later stages other proteins such as serpins are more effective in plant defence

The induction of an endosperm B-amylase after infection was detected (ID 362). An effect of the fungal infection in combination with the induction of proteins involved in carbon metabolism has been discussed in the literature (Campo et al. 2004; Wang et al. 2005b). The beta-amylase induction is not only responsible for starch degradation, it is also related to programmed cell death (apoptosis) of grain cells. Therefore, the $\beta$ amylase of emmer grain might be triggered as a response to a massive fungal infection.

\section{Conclusions}

Inoculation of emmer with Fusarium leads to the infection of ears resulting in DON concentrations up to $10 \mathrm{mg} \mathrm{kg}^{-1}$ in the grain. Carbon concentrations and crude protein content were not significantly changed by infection, but ten distinct proteins changed in abundance. Stress-related proteins such as peroxidase, peroxiredoxin and glycosyltransferase increased upon infection, whereas thaumatin and a chitinase decreased. Furthermore, three storage proteins found in emmer grains (an $\alpha$-gliadin and two globulins) were affected by Fusarium infection. The proteins detected gave useful hints for further Fusarium-based resistance breeding and helped to elucidate the mechanisms of defence against fungal infection to be found in cereal grains.

\section{Acknowledgements}

This work is part of the FAEN Joint Project 3 "Quality-related plant production under modified basic conditions: mycotoxins in the context of production, quality and processing", financed by the Ministry of Science and Culture of Lower Saxony, Germany. Special thanks are given to the grower Eckard Irion, Verein für Pflanzenzucht, Hof Grub e.V., who provided the seeds for this research trial as well as to the group of Prof. Petr Karlovsky, and especially to Sasithorn Limsuwan, Molecular Phytopathology and Mycotoxin Research, Department of Crop Science, Georg-August University Goettingen for the toxin analysis. 


\section{References}

Abonyi, T., Kiraly, I., Tomoskozi, S., Baticz, O., Guoth, A., Gergely, S., Scholz, E., Lasztity, D., and Lasztity, R. 2007. Synthesis of gluten-forming polypeptides. 1. Biosynthesis of gliadins and glutenin subunits. Journal of Agricultural and Food Chemistry 55:3655-3660.

Adejumo, T.O., Hettwer, U., and Karlovsky, P. 2007. Occurrence of Fusarium species and trichothecenes in Nigerian maize. Int. J. Food Microbiol. 116:350-357.

Altenbach, S.B., Tanaka, C.K., Hurkman, W.J., and Vensel, W.H. 2009. Expression of globulin2 , a member of the cupin superfamily of proteins with similarity to known food allergens, is increased under high temperature regimens during wheat grain development. J. Cereal Sci. 49:47-54.

Beyer, M., Klix, M.B., Klink, H., and Verreet, J.A. 2006. Quantifying the effects of previous crop, tillage, cultivar and triazole fungicides on the deoxynivalenol content of wheat grain - a review. J. Plant Dis. Prot. 113:241-246.

Bhadauria, V., Banniza, S., Wang, L.X., Wei, Y.D., and Peng, Y.L. 2010. Proteomic studies of phytopathogenic fungi, oomycetes and their interactions with hosts. Eur. J. Plant Pathol. 126:8195.

Boyacioglu, D., and Hettiarachchy, N.S. 1995. Changes in Some Biochemical-Components of Wheat-Grain That Was Infected with Fusarium-Graminearum. J. Cereal Sci. 21:57-62.

Buerstmayr, H., Stierschneider, M., Steiner, B., Lemmens, M., Griesser, M., Nevo, E., and Fahima, T. 2003. Variation for resistance to head blight caused by Fusarium graminearum in wild emmer (Triticum dicoccoides) originating from Israel. Euphytica 130:17-23.

Campo, S., Carrascal, M., Coca, M., Abian, J., and San Segundo, B. 2004. The defense response of germinating maize embryos against fungal infection: A proteomics approach. Proteomics 4:383-396.

Caruso, C., Chilosi, G., Caporale, C., Leonardi, L., Bertini, L., Magro, P., and Buonocore, V. 1999. Induction of pathogenesis-related proteins in germinating wheat seeds infected with Fusarium culmorum. Plant Sci. 140:87-97.

Dixon, R.A. 2001. Natural products and plant disease resistance. Nature 411:843-847.

Eggert, K., Wieser, H., and Pawelzik, E. 2010. The influence of Fusarium infection and growing location on the quantitative protein composition of (part I) emmer (Triticum dicoccum). Eur. Food Res. Technol. 230:837-847.

Eriksen, G.S., and Pettersson, H. 2004. Toxicological evaluation of trichothecenes in animal feed. Anim. Feed Sci. Technol. 114:205-239.

Foroud, N.A., and Eudes, F. 2009. Trichothecenes in Cereal Grains. Int. J. Mol. Sci. 10:147173.

Geddes, J., Eudes, F., Laroche, A., and Selinger, L.B. 2008. Differential expression of proteins in response to the interaction between the pathogen Fusarium graminearum and its host, Hordeum vulgare. Proteomics 8:545-554.

Gorg, A., Obermaier, C., Boguth, G., Harder, A., Scheibe, B., Wildgruber, R., and Weiss, W. 2000. The current state of two-dimensional electrophoresis with immobilized $\mathrm{pH}$ gradients. Electrophoresis 21:1037-1053.

Granvogl, B., Gruber, P., and Eichacker, L.A. 2007. Standardisation of rapid in-gel digestion by mass spectrometry. Proteomics 7:642-654.

Islam, N., Tsujimoto, H., and Hirano, H. 2003. Proteome analysis of diploid tetraploid and hexaploid wheat: Towards understanding genome interaction in protein expression. Proteomics 3:549-557. 
Jahn-Deesbach, W., Marquard, R., and Schipper, A. 1970. Untersuchungenüber den Einfluß von Sorte und Stickstoffdüngung auf die Eiweißfraktionen von Weizen und Gerste. Zeitschrift für Acker- und Pflanzenbau 132:151-162.

Kuwabara, C., Takezawa, D., Shimada, T., Hamada, T., Fujikawa, S., and Arakawa, K. 2002. Abscisic acid- and cold-induced thaumatin-like protein in winter wheat has an antifungal activity against snow mould, Microdochium nivale. Physiol. Plant. 115:101-110.

Lemmens, M., Scholz, U., Berthiller, F., Dall'Asta, C., Koutnik, A., Schuhmacher, R., Adam, G., Buerstmayr, H., Mesterhazy, A., Krska, R., and Ruckenbauer, P. 2005. The ability to detoxify the mycotoxin deoxynivalenol colocalizes with a major quantitative trait locus for fusarium head blight resistance in wheat. Mol. Plant-Microbe Interact. 18:1318-1324.

Lulin, M., Yi, S., Aizhong, C., Zenjun, Q., Liping, X., Peidu, C., Dajun, L., and Xiu-E, W. 2010. Molecular cloning and characterization of an up-regulated UDP-glucosyltransferase gene induced by DON from Triticum aestivum L. cv. Wangshuibai. Molecular biology reports 37:785-795.

Ndong, C., Danyluk, J., Wilson, K.E., Pocock, T., Huner, N.P.A., and Sarhan, F. 2002. Coldregulated cereal chloroplast late embryogenesis abundant-like proteins. Molecular characterization and functional analyses. Plant Physiol 129:1368-1381.

Neumann, C.A., Cao, J., and Manevich, Y. 2009. Peroxiredoxin 1 and its role in cell signaling. Cell Cycle 8:4072-4078.

Oliver, R.E., Stack, R.W., Miller, J.D., and Cai, X. 2007. Reaction of wild emmer wheat accessions to Fusarium head blight. Crop Sci. 47:893-899.

Parry, D.W., Jenkinson, P., and McLeod, L. 1995. Fusarium ear blight (SCAB) in small-grain cereals - a review. Plant Pathol. 44:207-238.

Pekkarinen, A.I., Longstaff, C., and Jones, B.L. 2007. Kinetics of the inhibition of Fusarium serine proteinases by barley (Hordeum vulgare L.) inhibitors. Journal of Agricultural and Food Chemistry 55:2736-2742.

Phalip, V., Delalande, F., Carapito, C., Goubet, F., Hatsch, D., Leize-Wagner, E., Dupree, P., Van Dorsselaer, A., and Jeltsch, J.M. 2005. Diversity of the exoproteome of Fusarium graminearum grown on plant cell wall. Curr. Genet. 48:366-379.

Radchuk, V.V., Borisjuk, L., Sreenivasulu, N., Merx, K., Mock, H.P., Rolletschek, H., Wobus, U., and Weschke, W. 2009. Spatiotemporal Profiling of Starch Biosynthesis and Degradation in the Developing Barley Grain. Plant Physiol. 150:190-204.

Roberts, T.H., and Hejgaard, J. 2008. Serpins in plants and green algae. Funct. Integr. Genomics $8: 1-27$.

Roberts, T.H., Marttila, S., Rasmussen, S.K., and Hejgaard, J. 2003. Differential gene expression for suicide-substrate serine proteinase inhibitors (serpins) in vegetative and grain tissues of barley. J. Exp. Bot. 54:2251-2263.

Shewry, P.R. 2009. Wheat. J. Exp. Bot. 60:1537-1553.

Shewry, P.R., and Halford, N.G. 2002. Cereal seed storage proteins: structures, properties and role in grain utilization. J. Exp. Bot. 53:947-958.

Shin, S.Y., Mackintosh, C.A., Lewis, J., Heinen, S.J., Radmer, L., Dill-Macky, R., Baldridge, G.D., Zeyen, R.J., and Muehlbauer, G.J. 2008. Transgenic wheat expressing a barley class II chitinase gene has enhanced resistance against Fusarium graminearum. J. Exp. Bot. 59:23712378.

Taylor, R.D., Saparno, A., Blackwell, B., Anoop, V., Gleddie, S., Tinker, N.A., and Harris, L.J. 2008. Proteomic analyses of Fusarium graminearum grown under mycotoxin-inducing conditions. Proteomics 8:2256-2265.

Thuvander, A., Wikman, C., and Gadhasson, I. 1999. In vitro exposure of human lymphocytes to trichothecenes: Individual variation in sensitivity and effects of combined exposure on lymphocyte function. Food Chem. Toxicol. 37:639-648. 
Tripathi, B.N., Bhatt, I., and Dietz, K.J. 2009. Peroxiredoxins: a less studied component of hydrogen peroxide detoxification in photosynthetic organisms. Protoplasma 235:3-15.

Wang, J.H., Wieser, H., Pawelzik, E., Weinert, J., Keutgen, A.J., and Wolf, G.A. 2005a. Impact of the fungal protease produced by Fusarium culmorum on the protein quality and breadmaking properties of winter wheat. Eur. Food Res. Technol. 220:552-559.

Wang, J.M., Chen, J.X., Dai, F., Wu, F.B., Yang, J.M., and Zhang, G.P. 2007. Protein fractions in barley grains as affected by some agronomic factors and their relationships to malt quality. Cereal Res. Commun. 35:129-140.

Wang, Y., Yang, L.M., Xu, H.B., Li, Q.F., Ma, Z.Q., and Chu, C.G. 2005b. Differential proteomic analysis of proteins in wheat spikes induced by Fusarium graminearum. Proteomics 5:4496-4503.

Yabe, T., Hashimoto, H., Sekijima, M., Degawa, M., Hashimoto, Y., Tashiro, F., and Ueno, Y. 1993. Effects of Nivalenol on Hepatic Drug-Metabolizing Activity in Rats. Food Chem. Toxicol. 31:573-581.

Yang, F., Jensen, J.D., H., S.N., Syensson, B., Jacobsen, B., Joergensen, L.N., Joergensen, H.J., Collinge, D.B., and Finnie, C. 2010. Investigation of the effect of nitrogen on severity of Fusarium

Yazar, S., and Omurtag, G.Z. 2008. Fumonisins, Trichothecenes and Zearalenone in Cereals. Int. J. Mol. Sci. 9:2062-2090.

Zhou, W.C., Kolb, F.L., and Riechers, D.E. 2005. Identification of proteins induced or upregulated by Fusarium head blight infection in the spikes of hexaploid wheat (Triticum aestivum). Genome 48:770-780.

Zhou, W.C., Eudes, F., and Laroche, A. 2006. Identification of differentially regulated proteins in response to a compatible interaction between the pathogen Fusarium graminearum and its host, Triticum aestivum. Proteomics 6:4599-4609.

Zorb, C., Schmitt, S., Neeb, A., Karl, S., Linder, M., and Schubert, S. 2004. The biochemical reaction of maize (Zea mays L.) to salt stress is characterized by a mitigation of symptoms and not by a specific adaptation. Plant Sci. 167:91-100. 



\title{
5.7 Proteome analysis of Fusarium head blight in grains of naked barley
}

\begin{abstract}
The effect of artificial Fusarium graminearum and Fusarium culmorum infection at the level of the proteome on grains from naked barley (Hodeum vulgare subsp. nudum) was investigated in comparison to controls. Fusarium infection leads in barley to numerous host-specific biochemical responses. NEPHGE 2D PAGE and mass spectrometry were used to identify proteins that were differentially expressed in response to fungal infection and growing location of the plants. Moreover, the field conditions of the location, carbon as well as nitrogen content, and the mycotoxin concentration of the grains were evaluated to characterize the infection success. Inoculation of naked barley with Fusarium led to grain deoxynivalenol concentrations of up to $1.2 \mathrm{mg} \mathrm{kg}^{-1}$. The carbon concentration and crude protein content were not significantly changed after fungal infection, but it differed between growing locations.

Eleven proteins related to fungal infection were detected as were three proteins with effects based on growing location. These proteins belong to different protein groups involved in various cell functions: transcription regulation, defence response, nutrient reservoirs and starch biosynthesis. The results showed plant defence strategies and changes as being an answer to Fusarium infection after a long infection period in the harvested grains as well as being influenced by the growing location.
\end{abstract}

Keywords: hull-less barley, serpins, pathogenesis-related proteins, nutrient reservoir proteins

\section{Introduction}

Naked barley (Hordeum vulgare subsp. nudum), also called hull-less barley, has in comparison to hulled barley a removable fibrous hull [1]. Two-rowed cultivars are predominant in production. The main producers of naked barley are Canada $(800,000 \mathrm{t})$ and the United States (5,000 t), but also Australia and some countries in Europe, Africa and Asia have a low production [1].

Fusarium head blight (FHB) induced by Fusarium spp. is a common disease of food grains like wheat, maize and barley and can lead to dramatic yield and quality losses [24]. The most relevant species in Europe associated with FHB are Fusarium graminearum (teleomorph: Gibberella zeae) and Fusarium culmorum [2, 5, 6]. However several pathogenic Fusarium species (F. graminearum, F. culmorum, F. poae, 
F. sporotrichoides and F. avenaceum) can infect barley grains and lead to the formation of mycotoxins such as deoxynivalenol (DON), nivalenol and T-2 toxin, among others $[7,8]$.

These mycotoxins when present in animal and human diets cause inappetence, vomiting, diarrhoea and bleeding of the intestines at high doses and lead to further effects like reduced impairment of immune function [9-11]. In the European Union, the mycotoxin problem has been addressed by establishing the maximum amounts of some Fusarium toxins allowed in products destined for food products [Commission Regulation (EC) No. 856/2005. 2006] and for animal nutrition [Commission Regulation (EC) No. 576/2006. 2006]. Moreover, mycotoxins are inhibitors of protein synthesis, with fungal enzymes leading to protein destruction and fungal infection to plant defence strategies; therefore, Fusarium infection is responsible for proteomic changes [9, 1214].

Fungal extra-cellular enzymes are produced to digest almost the complete plant cell wall. Functional class analysis of the enzymes involved showed that besides cell wall and starch decomposition enzymes there are several protein degradation enzymes involved such as serine protease, trypsin, carboxypeptidase, aminopeptidase and others [13]. Severe Fusarium infection has been shown to lead to the destruction of grain storage proteins in emmer cultivars due to the formation of proteinase $[15,16]$; however, this effect has not been found in Fusarium-infected naked barley and barley cultivars [17]. Therefore some defence mechanisms of the plant must exist that protect naked barley grains from destruction of their nutrient reservoir proteins and reduce infection success $[12,14,18]$. For this reason, pathogen exposure leads to changes in host proteins at different functional levels, such as cell signalling pathway, protein degradation, hormone production, apoptosis and rearrangement of the cytoskeleton [18]. Differential expression of proteins after fungal infection might be correlated to a plant's defence strategies. Results of this defence response have been reported as being changes in secondary metabolism or induction of proteins such as enzymes and enzyme inhibitors $[12,14,15]$. So far only a few data for the interaction between Fusarium spp. and wheat or maize at the level of distinct proteins are available and just one report exists for barley [19]. F. verticillioides infection of germinating maize led to the induction of antioxidative-acting enzymes which protect plants from antioxidative stress (e.g. superoxide dismutase, gluthatione-S-transferase, and catalase) [20]. Proteins involved in protein synthesis also control heat shock proteins which have also been 
found to be up-regulated in response to fungal infection, while some enzymes involved in carbon metabolism were down regulated [20]. A decrease in proteins involved in carbon metabolism and photosynthesis was observed in wheat spikes infected by $F$. graminearum, after a 6- to 24-h infection period. However, proteins related to stress response and defence were found to be up regulated (e.g. methyl-transferase, a heat shock protein, a jacaline-like-protein, and a ß-glucosidase) [21]. Two major groups of proteins were reported to respond to $F$. graminearum infection: one group with a potential function related to oxidative burst, signalling and pathogenesis-related proteins (PR proteins) and a second group involved in $\mathrm{C}$ and $\mathrm{N}$ metabolism. Therefore, the amino acid synthesis and $\mathrm{N}$ metabolism of the host were triggered by the influence of $F$. graminearum [22, 23]. A study with infected barley heads harvested after three days of infection obtained similar effects like those discussed before [24]. Moreover, a strong increase in PR proteins was detected for low susceptible barley genotypes, as well as a strong response of an oxidative burst and a de novo expression of a chitinase, all of which show differences in the pathogenesis response between cultivars with different sensitivities [24].

Despite these previous studies, the resistance potential of naked barley cultivars to fungal infection is still unclear and as a consequence, what happens at the level of the grain proteome in response to a fungal infection of naked barley accompanied by mycotoxin production is largely unknown. Only a few limited studies are available, though each with shortcomings such as short-term infection or without any evaluation of the infection degree, nor was there any consideration of the barley's proteome. The present study evaluates the proteome of mature grains of a naked barley cultivar after long-term artificial infection with Fusarium spp. under field conditions in comparison to a control.

\section{Materials and Methods}

\section{Experimental design and sample preparation}

The two-row naked barley cultivar ZFS was grown in 2008 in two field trials at the locations Reinshof and Sattenhausen near Göttingen (Germany). The plots were randomized with eight replications each. The second row of each block was artificially inoculated with a mixed F. culmorum plus F. graminearum spore suspension $\left(50 \mathrm{ml} \mathrm{m}^{-}\right.$ ${ }^{2} ; 1 \times 10^{5}$ spores $\mathrm{ml}^{-1}$ ) seven times during flowering and ripening. Three DON-producing strains of F. culmorum (FC34, FC35, FC36) and F. graminearum (FG142; FG143; FG144) were used for conidiospore production. Whole grain flour was obtained by 
milling (Retsch ZM 100, Haan, Germany) to a particle size of $0.5 \mathrm{~mm}$. For the comparison of natural and artificial infection as well as for location comparison, eight replications were available.

The conditions at Reinshof were: $152 \mathrm{~m}$ above sea level, wind sheltered and dale area near a river. The $\mathrm{N}_{\min }$ content was $19 \mathrm{~kg} \mathrm{ha}^{-1}$ recorded in $90-\mathrm{cm}$ soil depth; an additional fertilization with $50 \mathrm{~kg} \mathrm{~N} \mathrm{ha}^{-1}$ was conducted 18 and 37 days after sowing. The conditions at Sattenhausen were: $260 \mathrm{~m}$ above sea level, hilly and windy area. The $\mathrm{N}_{\min }$ content was $29 \mathrm{~kg} \mathrm{ha}^{-1}$ in $90 \mathrm{~cm}$ dry soil; an additional fertilization with $90 \mathrm{~kg} \mathrm{~N} \mathrm{ha}^{-1}$ was conducted 12 days before sowing.

\section{LC-MS-MS of deoxynivalenol (DON)}

The ground grains were extracted with acetonitrile-water $(84: 16)$ and the extracts were cleared, defatted, concentrated and filtered as described previously by Adejumo et al. 2007 [25]. The analytes were separated by HPLC on polar modified C18 phase (Polaris Ether, Varian GmbH, Darmstadt, Germany) using a methanol-water gradient (15\% to $70 \%$ during $20 \mathrm{~min}$ ) containing $0.2 \mathrm{mM}$ ammonium acetate. DON was detected by tandem mass spectrometry as described by Klötzel et al. 2006 [26]. Calibration curves were prepared from the mixture of acetonitrile-water with non-infected wheat flour spiked with certified analytical standards purchased from Biopure Co. Ltd (Austria) and processed in the same way as the samples.

\section{Quantitative nitrogen and carbon analysis}

The nitrogen and carbon content of 100-mg dry samples were quantitatively measured with a $\mathrm{C} / \mathrm{N}$-analyser (Vario MAX CN Elementar Analyse System GmbH, Hanau, Germany). The $\mathrm{N}$ content was then converted to protein using the factor 6.25 for barley (ICC No. 105/2) [27].

\section{Protein extraction}

The milled whole grain barley flour samples were extracted and prepared for 2DE by the following procedure. The flour samples were weighed and then homogenized by grinding in a mortar under liquid nitrogen. The homogenates were subsequently delipidated by extraction with diethyl ether. Following the removal of any residual ether under vacuum, approx. $30 \mathrm{mg}$ of each sample was extracted by the addition of $1.5 \mathrm{ml}$ extraction buffer (50 mM Tris-Cl, pH 7.4, $50 \mathrm{mM} \mathrm{NaCl,} \mathrm{1 \%} \mathrm{TWEEN-80,} \mathrm{and} 200 \mathrm{mM}$ ß-mercapto-ethanol). The extraction was performed under rapid agitation at $37^{\circ} \mathrm{C}$ for 30 min. The extracts were clarified by centrifugation at $14,000 \mathrm{rpm}$ for $10 \mathrm{~min}$ at RT. The 
supernatants were transferred to new containers and the proteins precipitated by the addition of 4 volumes of ice-cold ethanol. The resulting pellets were redissolved in 200 $\mu 1$ of AP buffer, containing 9M urea, 2\% ampholytes, 2\% Chaps, 1\% Tween-20, $70 \mathrm{mM}$ DTT, $12.5 \mathrm{mM}$ Tris-Cl, $\mathrm{pH}$ 7.1, $25 \mathrm{mM} \mathrm{KCl,} 1.5 \mathrm{mM}$ EDTA and a protease inhibitor cocktail. The solubilisation of the proteins was promoted by treatment of the extraction samples in an ultrasonic bath for $10 \mathrm{~min}$, with a chilling period of $5 \mathrm{~min}$ and repeated ultrasound treatment for $10 \mathrm{~min}$. Following a final clarification of the samples by centrifugation at $14 \mathrm{krpm}, 10 \mathrm{~min}$, RT, the samples were subjected to NEPHGE. Routinely, $88 \mu \mathrm{l}$ (1.2 $\mathrm{mg}$ protein) of each sample were applied to a $2 \mathrm{~mm}$ ID NEPHGEIEF gel in the $1^{\text {st }}$ dimension of $2 \mathrm{D}$.

\section{NEPHGE 2D PAGE}

The protocols employed for preparation of the $1^{\text {st }}$ and $2^{\text {nd }}$ dimension gels and solutions as well as for the electrophoresis conditions were essentially those described by Klose \& Kobalz [28], with proprietary modifications as defined in the WITA 2D PAGE standard operating procedure manual (WITA GmbH, Teltow, Germany). All the 2DE gels were run according to WITA's standard 2DE electrical protocols. After completion of the $2^{\text {nd }}$ dimension, the proteins were visualized by staining with Coomassie Brilliant Blue G-250 (colloidal CBB staining) according to standard laboratory protocols. Digitalization of the 2DE gels was done on a Mikrotec Scanmaker 9800 XL visible light scanner (Evestar GmbH, Willich, Germany) equipped with a trans-illumination unit at 300 dpi resolution and 16 bit data format. The scan data were stored as tif-format files compatible with most 2D data evaluation software packages.

Software based evaluation of $2 \mathrm{D}$

The evaluation of the data sets obtained from all 2D gels was performed with Melanie ${ }^{\circledR}$ (GeneBio SA, Geneva, Switzerland) 2D data processing package. Spot detection was done automatically with subsequent manual correction, as well as spot matching as a second step. The statistical comparison and spot candidate definition are presented in the results section. Candidate spots from CBB-G250-stained 2DE gels were subjected to protein identification according to WITA's standard operation protocols for tryptic fingerprint MALDI TOF MS and nanoLC-MS-MS. 
The chemicals and water used were of MALDI-MS, LC-MS or protein-sequenceanalysis grade, respectively. All chemicals and solvents were freshly prepared. Laboratory glassware (Reacti-vials Small, Pierce, Thermo Fischer Scientific, Germany) for MALDI preparation was cleaned using methanol and water. Reaction containers (glass vials, etc.) were exclusively used for MS.

For digestion, the spots were excised and reduced with 100mM DTT (alternatively alkylated with $25 \mathrm{mM}$ iodoacetamide), dehydrated at $50 \%$ and $80 \%$ acetonitrile $(\mathrm{v} / \mathrm{v})$, treated with $50 \mathrm{ng}$ sequencing grade trypsin (Roche Diagnostics, Germany) in a buffer containing $25 \mathrm{mM}$ ammonium bicarbonate, $\mathrm{pH} 8.0 \mathrm{O} / \mathrm{N}$ at $37^{\circ} \mathrm{C}$. For $\mathrm{V} 8$ digestion, 50 ng enzyme (Roche Diagnostics, Germany) was used at room temperature. Peptide extraction was performed with $20 \mu 10.2 \%$ trifluoroacetic acid, $20 \%$ acetonitrile and $50 \%$ acetonitrile (all v/v). The peptide mixture was lyophilized and re-dissolved in $0.2 \%$ trifluoroacetic acid.

For nanoLC- MS-MS, the total volume of the samples was injected into the nLC-ESI system. Data collection was performed automatically on a Bruker esquire HCT mass spectrometer using the HyStar 2.3 (method: ch-091001c) and esquireControl (method: ch_autoMSMS_090612) software (Bruker Daltonics, Bremen, Germany). The analysis and post-processing of chromatograms / spectra were performed employing HyStar PP 2.3 and DataAnalysis 5.4 (Bruker Daltonics). The identification of proteins was performed via Bio-Tools 2.2 (Bruker Daltonics) and Mascot Server 2.0 (Matrix Science Ltd., London, UK) using the NCBInr database.

For statistical analysis, the mean value, standard deviation and significance were calculated using Microsoft Excel 2003.

\section{Results}

\section{LC-MS-MS of DON}

The artificial infection led to fungal growth and formation of DON in the grains. The toxin concentrations were in the range of up to $1.2 \mathrm{mg} \mathrm{kg}^{-1}$ (Table 1). Comparing the locations, the grains from Sattenhausen contained a fourfold higher DON content than the grains from Reinshof.

Quantitative nitrogen and carbon analysis

The concentrations of $\mathrm{C}, \mathrm{N}$ and crude protein as well as the $\mathrm{C} / \mathrm{N}$-ratio in the naked barley grains changed only slightly and were not significant (data not shown) with respect to the Fusarium infection at either location (Table 1). Comparing the two 
locations, no significance difference in $\mathrm{C}$ concentration was detectable (Table 1). A significant $(\mathrm{p}<0.001)$ difference in $\mathrm{N}$ concentration was detected which resulted in a significantly $(\mathrm{p}<0.001)$ higher $\mathrm{C} / \mathrm{N}$ ratio in the grains from Sattenhausen and a significantly $(p<0.001)$ higher protein content in the grains from Reinshof. The results of the higher $\mathrm{N}$ concentration in the grains from Reinshof may have been caused by the site's higher soil $\mathrm{N}$ availability and the different times of fertilization used at the two locations (see Material and Methods).

Table 1 DON concentrations ( $\mathrm{mg} \mathrm{kg}^{-1}$ whole grain flour), carbon $(\mathrm{C})$, nitrogen $(\mathrm{N})$ and crude protein content of naturally and artificially infected naked barley grains (cultivar ZFS) from the locations Sattenhausen and Reinshof. (protein, factor, 6.25; ICC No. $105 / 2)$

\begin{tabular}{|c|c|c|c|c|c|c|c|}
\hline \multirow[t]{2}{*}{ Location } & \multirow[t]{2}{*}{ Parameter } & \multicolumn{3}{|c|}{ Control } & \multicolumn{3}{|c|}{ Artificial infection } \\
\hline & & MV & & SD & MV & & SD \\
\hline \multirow[t]{5}{*}{ Sattenhausen } & $\mathrm{DON}\left(\mathrm{mg} \mathrm{kg}^{-1}\right)$ & - & \pm & - & 1.2 & \pm & 0.3 \\
\hline & $\mathrm{C} \%$ & 44.9 & \pm & 0.3 & 45.0 & \pm & 0.3 \\
\hline & $\mathrm{N} \%$ & 2.2 & \pm & 0.0 & $2.2=$ & \pm & 0.04 \\
\hline & $\mathrm{C} / \mathrm{N}$-ratio & 20.1 & \pm & 0.2 & 20.2 & \pm & 0.3 \\
\hline & Protein \% & 14.0 & \pm & 0.2 & 13.9 & \pm & 0.3 \\
\hline \multirow[t]{5}{*}{ Reinshof } & $\mathrm{DON}\left(\mathrm{mg} \mathrm{kg}^{-1}\right)$ & - & \pm & - & 0.3 & \pm & 0.1 \\
\hline & C \% & 44.6 & \pm & 1.1 & 45.0 & \pm & 0.2 \\
\hline & $\mathrm{N} \%$ & 2.3 & \pm & 0.1 & 2.3 & \pm & 0.02 \\
\hline & $\mathrm{C} / \mathrm{N}$-ratio & 19.4 & \pm & 0.3 & 19.3 & \pm & 0.1 \\
\hline & Protein \% & 14.4 & \pm & 0.5 & $14.6=$ & \pm & 0.1 \\
\hline
\end{tabular}

$\mathrm{MV}=$ mean value; $\mathrm{SD}=$ standard deviation

\section{Proteome analysis}

We detected approximately 730 protein spots on 2D gels resolved in the $\mathrm{pH}$ range 4-8.5 from the naked barley cultivar ZFS. This is a rise of around $20 \%$ in separated spot quantity in comparison to another report [24]. After statistical evaluation of all the spots and the calculation of the ratio of the artificially infected samples and the controls, only 11 spots (proteins) were found to be changed based on infection and an additional three 
spots were altered due to the growing location. These 14 proteins were subsequently identified using MALDI TOF MS or nanoLC-MS/MS (Table 2; Fig. 1). The changed protein spots were found to belong to different protein groups: transcription regulation (five spots), defence response (six spots, three of them also nutrient reservoirs), nutrient reservoirs (four spots, three also defence response), one involved in starch biosynthesis and one with an unknown function (Table 2; Fig. 1).

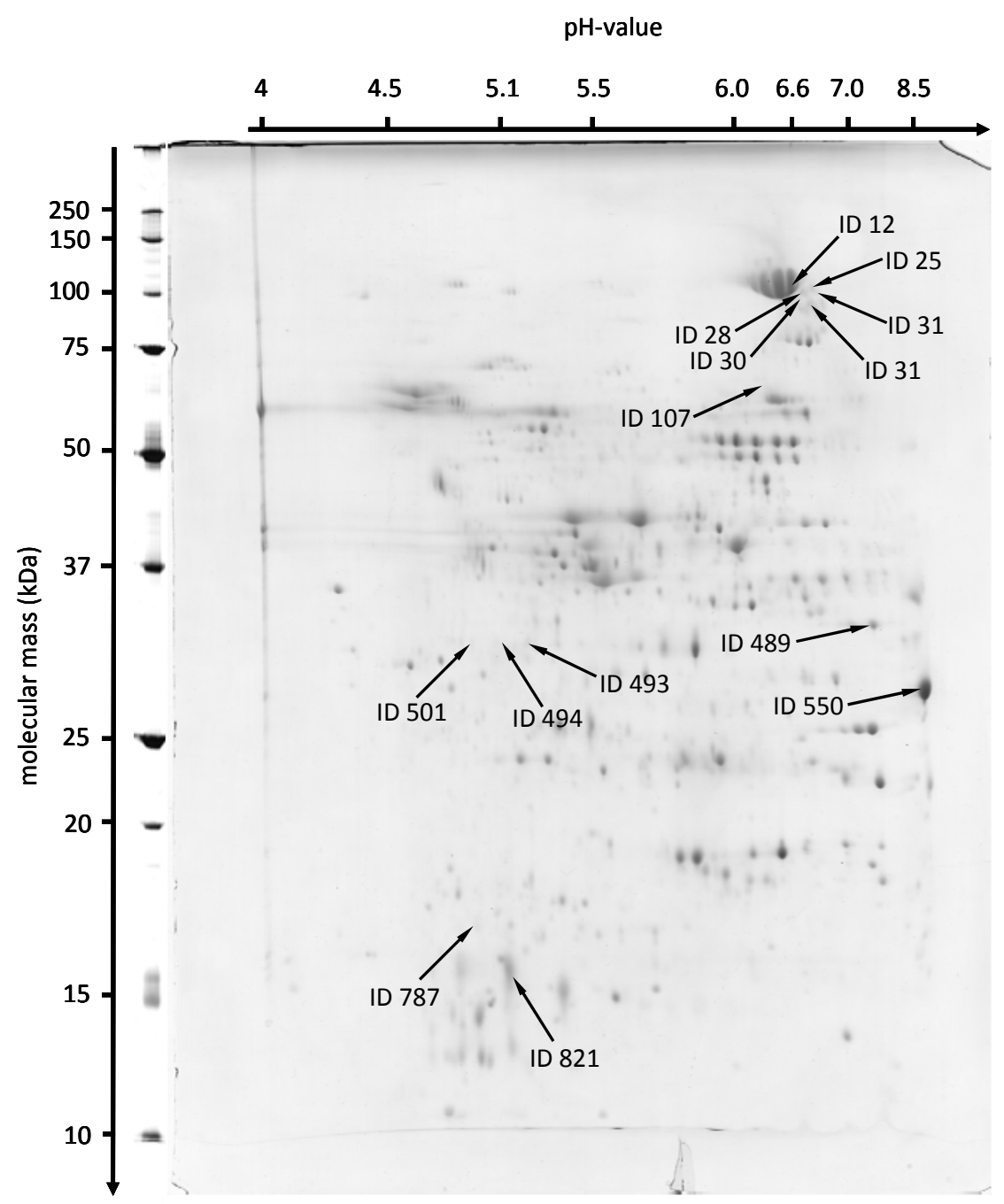

Figure 1 Two-dimensional protein gel of naked barley grains of 12\% NEPHGE SDS PAGE, IEP range, $\mathrm{pH}$ 4-8.5, $18 \mathrm{~cm}$, linear strip; colloidal CBB staining; changed protein spots are marked with arrows and ID numbered according to Tables 2 and 3 (ID12 D-hordein, ID25 RNA polymerase, ID28 Zinc finger protein, ID 30 Disease resistance protein, ID31 Zinc finger protein, ID35 Zinc finger protein, ID107 Transcription factor, ID 489 Endochitinase, ID493 Serpin-Z4, ID494 Serpin-Z type, ID 501 Serpin-Z type, ID 550 Protein synthesis inhibitor, ID 787 Glucose phosphorylase, ID 821 Hypothetical protein). 
The proteins up-regulated in the artificially infected samples in comparison to the controls are part of the protein group that is involved in the regulation of transcription. We found a DNA-direct RNA polymerase (Table 2, Figs. 1 \& 2; ID 25), three Dof zinc finger proteins (Table 2, Figs. 1, \& 2; ID 28, 31, 35) and one AT5G10030-like protein (Table 2, Figs. 1; ID 107). One NBS-LRR disease-resistance protein (Table 2, Figs. $1 \&$ 2; ID 30) and three serpins with protease-inhibitor and nutritional-reservoir functions were also up-regulated (Table 2, Figs. $1 \& 2$; ID 493, 494, 501).

Proteins down-regulated in the artificially infected samples in comparison to the control grains are part of the protein group that is involved in starch synthesis (Table 2, Figs. 1; ID 787) and an hypothetical protein with an unknown function (Table 2, Figs. 1; ID 821). Additionally, we found depending on the growing location one reduced D-hordein quantity which acts as nutrient reservoir protein (Table 2, Figs. 1 \& 3; ID 12), one endochitinase that hydrolyses fungal chitin (Table 2, Figs. 1 \& 3; ID 489), and one protein synthesis inhibitor that acts as antifungal agent (Table 2, Figs. $1 \& 3$; ID 550). 
Table 2 Compilation of information about eleven proteins changed in abundance upon infection with Fusarium spp. in naked barley grains at the locations Sattenhausen and Reinshof. Ratio (relative units) between naturally and artificially infected proteins detected by two-dimensional gel electrophoresis (see Materials and methods). Identification of proteins by Mascot score with MALDI TOF MS (see Material and methods). Spot ID see Figure $1(\mathrm{p}=$ significance at $\mathrm{p}<0.05 ; \mathrm{MV}=$ mean value; $\mathrm{SD}=$ standard deviation $)$

\begin{tabular}{|c|c|c|c|c|c|c|c|c|c|c|c|c|c|c|c|c|}
\hline \multirow{2}{*}{ Spot ID } & \multicolumn{3}{|c|}{ Control } & \multicolumn{3}{|c|}{$\begin{array}{l}\text { Artificially } \\
\text { infected }\end{array}$} & \multirow{2}{*}{\multicolumn{2}{|c|}{ Ratio }} & \multirow{2}{*}{$\mathrm{p}$} & \multirow{2}{*}{ Identification } & \multirow{2}{*}{ Function } & \multirow{2}{*}{$\begin{array}{l}\text { Protein } \\
\text { homologue }\end{array}$} & \multirow{2}{*}{ pl exper. } & \multirow{2}{*}{$\begin{array}{c}\text { Peptids/M } \\
\text { ascot } \\
\text { Score }\end{array}$} & \multirow{2}{*}{ Accession No. } & \multirow{2}{*}{$\begin{array}{l}\text { Mass } \\
(\mathrm{kDa})\end{array}$} \\
\hline & MV & & SD & $\mathrm{MV}$ & & SD & & & & & & & & & & \\
\hline 25 & 0.13 & \pm & 0.04 & 0.18 & \pm & 0.03 & +1.37 & $<$ & 0.02 & $\begin{array}{l}\text { DNA-directed RNA } \\
\text { polymerase }\end{array}$ & transcription of DNA into RNA & $\begin{array}{l}\text { Hordeum } \\
\text { vulgare }\end{array}$ & 7.9 & $14 / 52$ & gi|34481849 & 107 \\
\hline 28 & 0.14 & \pm & 0.06 & 0.20 & \pm & 0.06 & +1.43 & $<$ & 0.05 & Dof zinc finger protein & $\begin{array}{l}\text { DNA binding, regulation of } \\
\text { transcription }\end{array}$ & $\begin{array}{l}\text { Hordeum } \\
\text { vulgare }\end{array}$ & 7.8 & $7 / 54$ & gi|148472746 & 22 \\
\hline 30 & 0.08 & \pm & 0.05 & 0.16 & \pm & 0.05 & +1.92 & $<$ & 0.01 & $\begin{array}{l}\text { NBS-LRR disease } \\
\text { resistance protein }\end{array}$ & $\begin{array}{l}\text { Apoptosis as defence response } \\
\text { (ATP binding) }\end{array}$ & $\begin{array}{l}\text { Hordeum } \\
\text { vulgare }\end{array}$ & 7.8 & $10 / 48$ & gi|28555904 & 99 \\
\hline 31 & 0.06 & \pm & 0.02 & 0.11 & \pm & 0.02 & +1.76 & $<$ & 0.0005 & Dof zinc finger protein & $\begin{array}{l}\text { DNA binding, regulation of } \\
\text { transcription }\end{array}$ & $\begin{array}{l}\text { Hordeum } \\
\text { vulgare }\end{array}$ & 7.9 & $18 / 58$ & gi|148472746 & 22 \\
\hline 35 & 0.12 & \pm & 0.04 & 0.18 & \pm & 0.03 & +1.44 & $<$ & 0.004 & Dof zinc finger protein & $\begin{array}{l}\text { DNA binding, regulation of } \\
\text { transcription }\end{array}$ & $\begin{array}{l}\text { Hordeum } \\
\text { vulgare }\end{array}$ & 7.9 & 7/71 & gi|148472747 & 22 \\
\hline 107 & 0.03 & \pm & 0.02 & 0.07 & \pm & 0.01 & +2.25 & $<$ & 0.0003 & AT5G10030-like protein & Transcription factor & $\begin{array}{l}\text { Arabidopsis } \\
\text { arenosa }\end{array}$ & 7.3 & $7 / 70$ & gi|217426814 & 45 \\
\hline 493 & 0.15 & \pm & 0.07 & 0.28 & \pm & 0.10 & +2.04 & $<$ & 0.01 & Serpin-Z4 & $\begin{array}{l}\text { Serine protease inhibitor, storage } \\
\text { protein }\end{array}$ & $\begin{array}{l}\text { Hordeum } \\
\text { vulgare }\end{array}$ & 6.0 & $12 / 159$ & gi|131091 & 43 \\
\hline 494 & 0.07 & \pm & 0.04 & 0.24 & \pm & 0.09 & +1.87 & $<$ & 0.0005 & Serpin-z-type & $\begin{array}{l}\text { Serine protease inhibitor, storage } \\
\text { protein }\end{array}$ & $\begin{array}{l}\text { Hordeum } \\
\text { vulgare }\end{array}$ & 5.7 & $14 / 217$ & gi|1310676 & 43 \\
\hline 501 & 0.04 & \pm & 0.04 & 0.16 & \pm & 0.10 & +3.25 & $<$ & 0.01 & Serpin-z-type & $\begin{array}{l}\text { Serine protease inhibitor, storage } \\
\text { protein }\end{array}$ & $\begin{array}{l}\text { Hordeum } \\
\text { vulgare }\end{array}$ & 5.6 & $14 / 199$ & gi|1310677 & 43 \\
\hline 787 & 0.10 & \pm & 0.02 & 0.05 & \pm & 0.02 & -2.15 & $<$ & 0.0001 & $\begin{array}{c}\text { ADP-glucose } \\
\text { pyrophosphorylase }\end{array}$ & $\begin{array}{l}\text { Glycan and starch biosynthesis in } \\
\text { chloroplast and amyloplast }\end{array}$ & $\begin{array}{l}\text { Hordeum } \\
\text { vulgare }\end{array}$ & 5.6 & $4 / 68$ & gi|1143498 & 56 \\
\hline 821 & 0.97 & \pm & 0.06 & 0.80 & \pm & 0.17 & -1.21 & $<$ & 0.02 & $\begin{array}{l}\text { Hypothetical protein: } \\
\text { OsJ_09625 }\end{array}$ & $? ? ?$ & Oryza sativa & 5.9 & $6 / 86$ & gi|222624292 & 21 \\
\hline
\end{tabular}


Table 3 Compilation of information about three proteins changed in abundance according to growing location in naked barley grains. Ratio (relative Units) between changed proteins depending on the location detected by two-dimensional gel electrophoresis (see Materials and methods). Identification of proteins by Mascot score: identification using nanoLC-MS/MS de-novo-synthesis and MALDI TOF MS, (see Material and methods). Spot ID see Figure $1(\mathrm{p}=$ significance at $\mathrm{p}<0.05 ; \varnothing=$ mean of both naturally and artificially infected samples at one location; $\mathrm{MV}=$ mean value; $\mathrm{SD}=$ standard deviation)

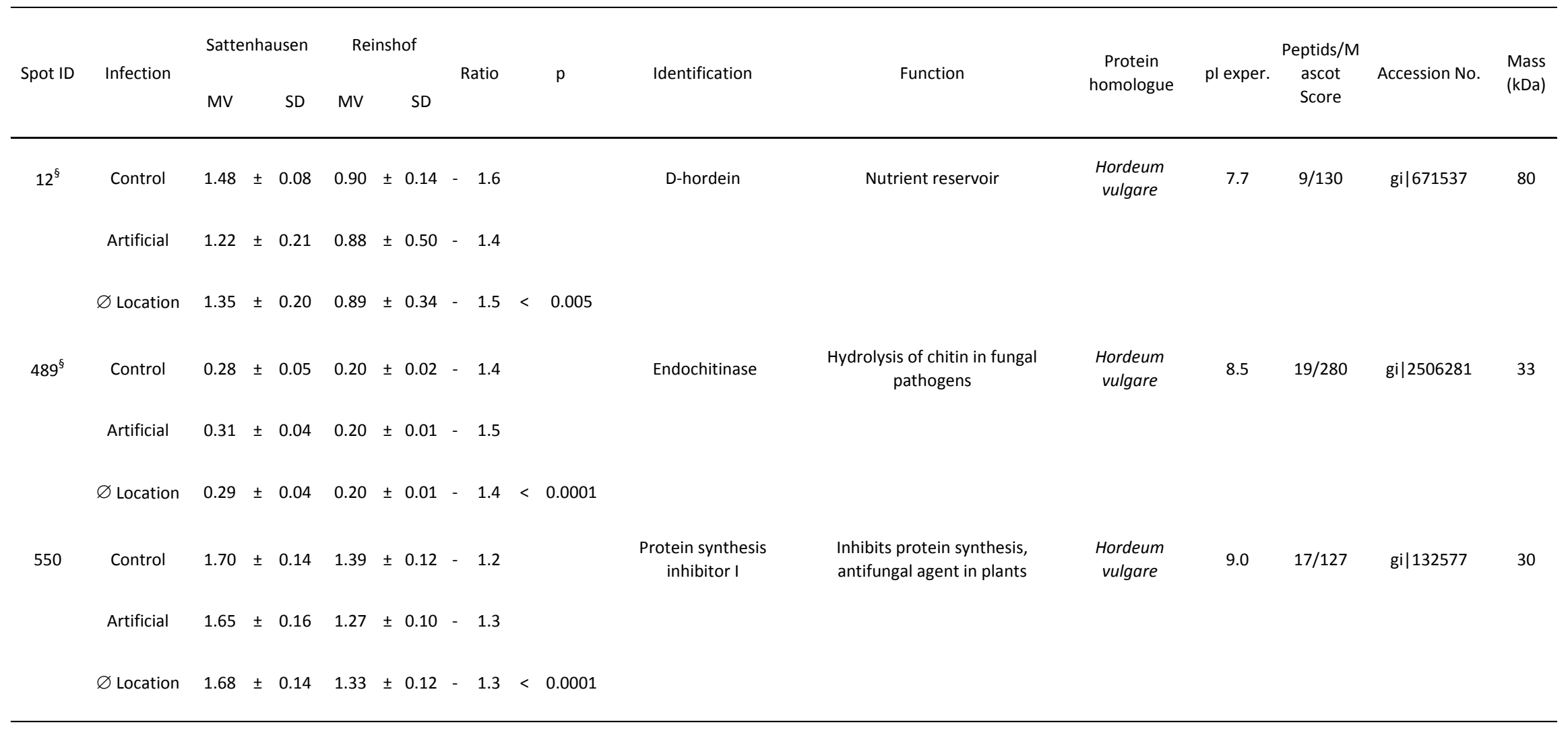




\section{Discussion}

\section{LC-MS-MS of DON}

The occurrence of FHB and subsequent DON accumulation in barley is known to be a world-wide problem [29]. This disease not only causes yield loss, but it can lead to reduced seed quality by contaminating the infected grains with trichothecenes toxins and alter the protein biosynthesis in infected grains [24, 30, 31]. In the present study, DON formation was detected in the artificially infected samples, while no toxin contamination of the samples was found in the controls (Table 1). The present results are in accordance with other studies showing a low susceptibility to Fusarium infection in two-row cultivars $[29,32]$. In our study, the artificial infection was successful and a clear influence of the location was detected. The conditions at the two different locations led to a fourfold (Table 1) higher toxin accumulation in the grains at Sattenhausen compared to those at Reinshof. Local weather conditions together with local cropping methods (crop rotation, soil preparation) are important influences and can explain the variations found between the two locations [33].

\section{Quantitative nitrogen and carbon analysis}

The results showed that the artificial Fusarium infection had no effect on $\mathrm{C}, \mathrm{N}$ or the calculated protein contents. Nevertheless, differences due to the growing location were apparent (Table 1). $\mathrm{N}$ availability of plants especially in the grain-filling phase leads to higher $\mathrm{N}$ and crude protein concentrations in the grains [34]. $\mathrm{N}$ availability in the early stages of plant growth based on the time of fertilization may be one of the promoting factors for gene expression and might be responsible for the higher storage protein generation in the grains from Sattenhausen compared to those from Reinshof (Table 3) [35]. The higher $\mathrm{N}$ and protein concentrations in the grains from Reinshof might be a consequence of the higher $\mathrm{N}$ availability in the soil at later development stages due to the different time of fertilization. The higher $\mathrm{N}$ concentrations with nearly unchanged $\mathrm{C}$ concentrations, therefore, led to a lower $\mathrm{C} / \mathrm{N}$ ratio in the grains grown at Reinshof. An effect of the higher $\mathrm{N}$ concentrations on the $\mathrm{C}$ fractions was not detectable because the C concentrations did not change (Table 1). 


\section{Proteome analysis}

Comparing the artificially infected naked barley grains with the control grains, we found nine proteins to be up-regulated. The chloroplast DNA-direct RNA polymerase (Table 2, Figs. 1 \& 2; ID 25) was up-regulated by around 40\%. Plastid RNA polymerase uses four ribonucleoside triphosphates as substrates to catalyze the transcription of DNA into RNA [36, 37]. The functions of the up-regulated plastid RNA polymerase are involved in the translation of house-keeping genes and photosynthesis genes [38]. The up-regulation here can possibly be explained by the loss of function in barley chloroplasts of Fusarium-infected tissue, because chloroplasts are known to be the organelles most affected by Fusarium infection [22].

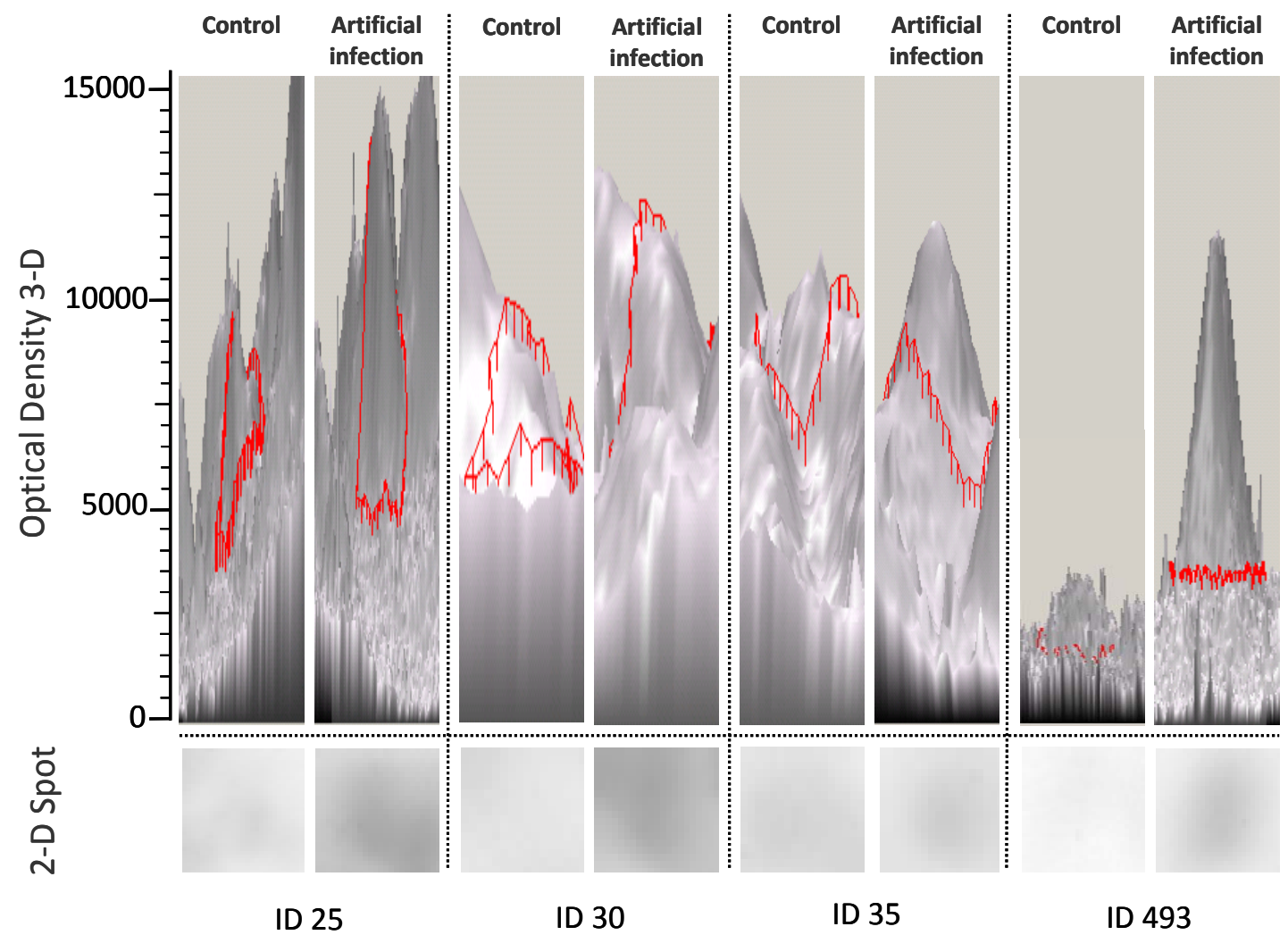

Figure 2 Comparison of selected artificially Fusarium infected 3D and 2D visualised protein spots of naked barley grains in comparison to the control, (regulation of transcription: ID25 RNA polymerase, ID35 Zinc finger protein; defence response: ID 30 Disease resistance protein, ID493 Serpin-Z4) 12\% NEPHGE SDS PAGE, IEP range, pH 4-8.5, $18 \mathrm{~cm}$, linear strip; colloidal CBB staining; ID numbered according to Table 
Three Dof zinc finger proteins were found up-regulated by between 40 and 75\% (Table 2, Figs. 1, \& 2; ID 28, 31, 35). Dof zink finger proteins are transcription factors with functions which regulate plant-specific genes and mediate a variety of plant-specific signals. They may, therefore, be involved in defence response and phytohormone response [39, 40]. The induction of Dof zink finger proteins could be the consequence of Fusarium infection in connection with the defence response. Additionally, an influence on the endosperm-specific expression of storage proteins has already been discussed for maize, wheat and barley [40]. This can be explained as an induction of storage protein production to ensure the pool of nutrient reservoir proteins for germination because Fusarium infection and later toxin production lead to an inhibition of protein biosynthesis [9].

AT5G10030-like protein (Table 2, Figs. 1; ID 107), another transcription factor, belongs to the basic domain-leucine zipper (bZIP) family and plays probably the same role as the family of Dof zink finger proteins, i.e. as a defence or stress response against pathogens [41]. This aspect can explain its induction of 125\% after Fusarium infection in comparison to control samples. The higher induction of this transcription factor in comparison to the Dof zink finger proteins is presumably due to its having a stronger involvement in the defence response against fungal pathogens (Table 2; ID 28, 31, 35, 107).

The NBS-LRR (nucleotide binding site-leucine rich repeat) disease resistance protein (Table 2, Figs. $1 \& 2$; ID 30) was up-regulated by around 90\% after artificial Fusarium infection. This protein interacts directly or indirectly with pathogen molecules and is involved in host-protein and host-pathogen recognition [42]. As result of these functions, its interactions with pathogen proteins could result in protein inactivation (e.g. enzymes) and a reduction in fungal growth. 


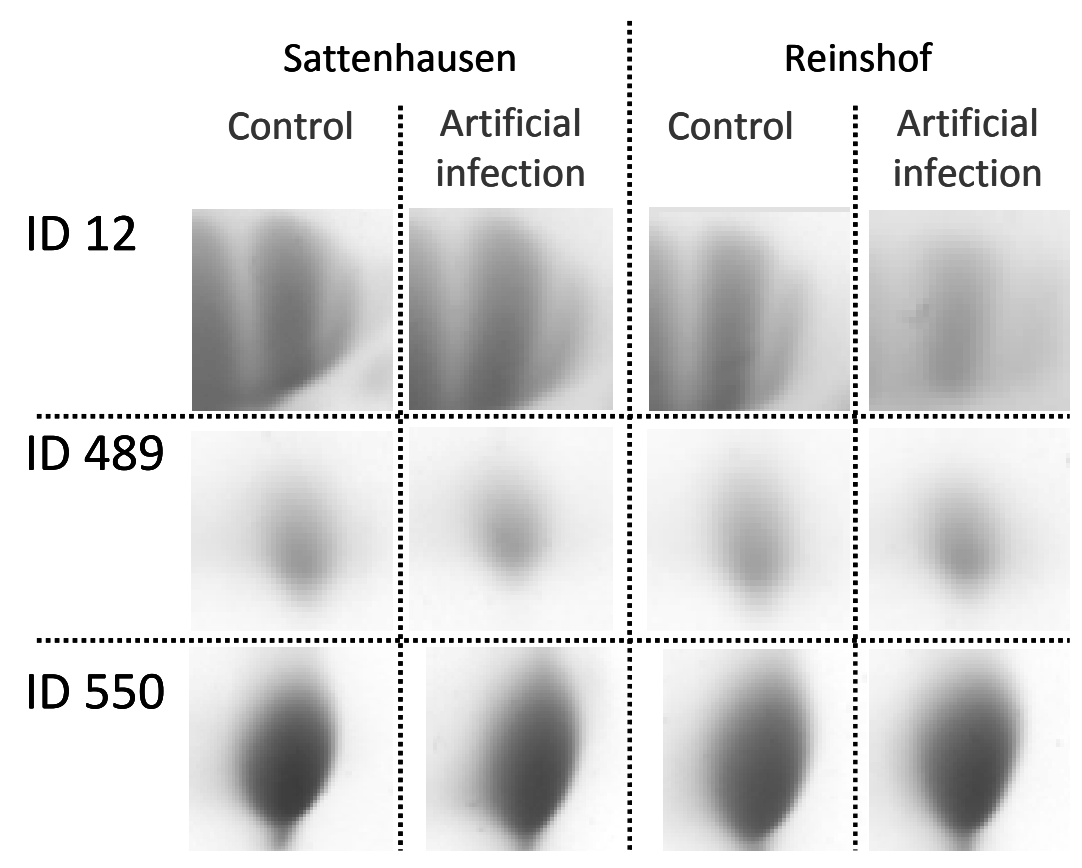

Figure 3 Comparison of selected artificially Fusarium-infected 2D visualised protein spots of naked barley grains in comparison to controls and in dependence of growing location, (nutrient reservoir: ID12 Zinc finger protein, ID12 D-hordein; defence response: ID 489 Endochitinase; ID 550 Protein synthesis inhibitor) 12\% NEPHGE SDS PAGE, IEP range, $\mathrm{pH}$ 4-8.5, $18 \mathrm{~cm}$, linear strip; colloidal CBB staining, ID numbered according to Table 2

The three up-regulated serpins (Table 2, Fig. 1 \& 2; ID 493, 494, 501) were induced after artificial infection by between 90 and $225 \%$ compared to the proteins in the control grains. Serpins are inhibitors of serin proteinases in barley and several such proteinases are known to occur in Fusarium $[12,13]$. The inhibition of fungal proteinases by the endogenous naked barley protease inhibitor, serpin, may prevent the digestion of seed storage proteins after fungal infection to a certain degree. Our data shows that in naked barley grains an infection with Fusarium leads to the induction of endogenous serine protease inhibitors. However, the infection of barley and wheat by Fusarium of about maximal three days did not lead to an induction of serpins [22, 24]. This implies that infection enhances serpin expression at the kernel development in the later stages of grain development, which has been supported by our recent study on the emmer proteome and Fusarium infection [15]. Serpins only function as storage proteins when they have lost their inhibitory activity [43]. The defence response of these proteins is certainly the main factor in this study. Additional results of the defence response 
probably lead to alternative functions in signalling by inhibition of signal peptide formation. Management by serpins may lead here to a change in signal peptide composition and results in a changed cell response as consequence of fungal infection [43].

ADP-glucose pyrophosphorylase was down-regulated in the artificially infected samples with $50 \%$ of the spot quantity found in the natural infection (Table 2, Figs. 1; ID 787). This protein is involved in starch biosynthesis in chloroplasts and amyloplasts [44]. An influence on enzymes involved in starch synthesis has been discussed already in earlier studies [22, 24, 45]; however, the reduction of ADP-glucose pyrophosphorylase in connection to Fusarium infection has been shown in the present investigation for the first time. This enzyme catalyses an important regulated step of starch synthesis in higher plants [44]. Nevertheless, we speculate that after fungal infection a regulation based on translation or transcription must take place to explain the reduced quantity of this enzyme. Transcription factors or phytohormones may be responsible for the lower quantity of enzyme present [39, 40].

The ca. $20 \%$ down-regulated protein was considered to be a hypothetical protein with an unknown function (Table 2, Figs. 1; ID 821). The function and basis of the down regulation of this protein are also unknown. It is thought that a characterization of the naked barley proteome in comparison to hulled barley could possibly clarify the function of this unknown protein.

Depending on the growing location, three proteins were down regulated. D-hordein was down regulated by an average of $40 \%$ in the grains from Reinshof compared to those from Sattenhausen (Table 3, Figs. $1 \& 3$; ID 12). This reduced quantity of nutrient reservoir protein may be due to the $\mathrm{N}$ availability in the early stages of plant growth being dependent on the time of fertilization, which varied between the two locations. Promoting factors for gene expression might be responsible for a higher storage protein generation in the grains from Sattenhausen than in those from Reinshof (Table 3) [35] (see also Section 4.2 ). Additionally, an effect of the degree of artificial Fusarium infection is visible at both locations (Tables 1,3). The higher infection degree at Sattenhausen led here to a reduction in protein quantity of $18 \%$ compared to natural infection at the same location. In comparison, the fungal-infection-associated reduction was only about $2 \%$ in the grains from Reinshof. Fungal protease can destroy storage 
proteins, which is maybe the reason for reduced quantity of D-hordein found in this investigation $[16,46]$.

Considering the effect of location, we found a $30 \%$ lower quantity of endochitinase in the grains from Reinshof compared to those from Sattenhausen (Table 3, Figs. 1 \& 3; ID 489). Barley chitinase is an enzyme with a function against chitin-containing fungal pathogens [47]. The fourfold higher infection degree at Sattenhausen in the infected cultivars than at Reinshof (Table 1) led to a $10 \%$ induction of endochitinase at the former location but to no change in the grains at Reinshof (Table 3). This induction is based on its function as a plant defence molecule in barley and can lead to reduced infection and fungal growth of the pathogen [48, 49]. However, a total inhibition of fungal growth does not take place. As a consequence, it is possible to regard endochitinase content as factor for susceptibility management of the plant but not for total resistance.

In addition to endochitinase, a protein synthesis inhibitor that acts as an antifungal agent (Table 3, Figs. $1 \&$ 3; ID 550) was also more induced in the grains from Sattenhausen than those from Reinshof. The variation in the quantity of this enzyme according to location was around $20 \%$. The factor Fusarium infection led here to a slightly reduced quantity which showed that this protein is just affected by growing location but not by fungal infection. This protein synthesis inhibitor acts as a ribosome-inactivating protein of fungi [50]. These results show that this protein synthesis inhibitor can be positively affected by the location conditions as a plant defence molecule in barley. However, in our study, positive effects induced by the location did not lead to reduced infection and fungal growth of the pathogen.

In conclusion, we found that several proteins were changed in harvested naked barley grains after artificial Fusarium infection in comparison to naturally infected grains. These results have showed, for the first time, the plant defence strategies involved in Fusarium infection after a long infection period from flowering to harvest. In addition, these results as far as we know, show for the first time the characterization of infection success by fungal toxin (DON) quantification for naked barley [30, 31, 45]. Nevertheless, more studies on the influence of fungal infection on barley and naked barley cultivars are necessary to enhance the knowledge about plant defence against Fusarium and other fungal pathogens. 


\section{References}

[1] Bhatty, R. S., The potential of hull-less barley. Cereal Chem. 1999, 76, 589-599.

[2] Parry, D. W., Jenkinson, P., McLeod, L., Fusarium ear blight (scab) in small-grain cereals a review. Plant Pathol. 1995, 44, 207-238.

[3] Yazar, S., Omurtag, G. Z., Fumonisins, trichothecenes and zearalenone in cereals. Int. J. Mol. Sci. 2008, 9, 2062-2090.

[4] Bottalico, A., Perrone, G., Toxigenic Fusarium species and mycotoxins associated with head blight in small-grain cereals in Europe. Eur. J. Plant Pathol. 2002, 108, 611-624.

[5] Foroud, N. A., Eudes, F., Trichothecenes in cereal grains. Int. J. Mol. Sci. 2009, 10, $147-$ 173.

[6] Walter, S., Nicholson, P., Doohan, F. M., Action and reaction of host and pathogen during Fusarium head blight disease. New Phytol 2009, 185, 54-66.

[7] Perkowski, J., Kiecana, I., Kaczmarek, Z., Natural occurrence and distribution of Fusarium toxins in contaminated barley cultivars. Eur. J. Plant Pathol. 2003, 109, 331-339.

[8] Salas, B., Steffenson, B. J., Casper, H. H., Tacke, B., et al., Fusarium species pathogenic to barley and their associated mycotoxins. Plant Dis. 1999, 83, 667-674.

[9] Eriksen, G. S., Pettersson, H., Toxicological evaluation of trichothecenes in animal feed. Anim. Feed Sci. Technol. 2004, 114, 205-239.

[10] Thuvander, A., Wikman, C., Gadhasson, I., In vitro exposure of human lymphocytes to trichothecenes: Individual variation in sensitivity and effects of combined exposure on lymphocyte function. Food Chem. Toxicol. 1999, 37, 639-648.

[11] Yabe, T., Hashimoto, H., Sekijima, M., Degawa, M., et al., Effects of nivalenol on hepatic drug-metabolizing activity in rats. Food Chem. Toxicol. 1993, 31, 573-581.

[12] Pekkarinen, A. I., Longstaff, C., Jones, B. L., Kinetics of the inhibition of Fusarium serine proteinases by barley (Hordeum vulgare L.) inhibitors. J. Agric. Food Chem. 2007, 55, 27362742.

[13] Phalip, V., Delalande, F., Carapito, C., Goubet, F., et al., Diversity of the exoproteome of Fusarium graminearum grown on plant cell wall. Curr. Genet. 2005, 48, 366-379.

[14] Dixon, R. A., Natural products and plant disease resistance. Nature 2001, 411, 843-847.

[15] Eggert, K., Zörb, C., Mühling, K. H., Pawelzik, E., Proteome analysis of Fusarium head blight of emmer (Triticum dicoccum). 2010, under revision.

[16] Eggert, K., Wieser, H., Pawelzik, E., The influence of Fusarium infection and growing location on the quantitative protein composition of (Part I) emmer (Triticum dicoccum) Eur. $J$. Food Res. Technol. 2010, in press.

[17] Eggert, K., Wieser, H., Pawelzik, E., The influence of Fusarium infection and growing location on the quantitative protein composition of (Part II) naked barley (Hordeum vulgare nudum). Eur. J. Food Res. Technol. 2010, in press.

[18] Coiras, M., Camafeita, E., Lopez-Huertas, M. R., Calvo, E., et al., Application of proteomics technology for analyzing the interactions between host cells and intracellular infectious agents. Proteomics 2008, 8, 852-873.

[19] Bhadauria, V., Banniza, S., Wang, L. X., Wei, Y. D., Peng, Y. L., Proteomic studies of phytopathogenic fungi, oomycetes and their interactions with hosts. Eur. J. Plant Pathol., 126, 81-95.

[20] Campo, S., Carrascal, M., Coca, M., Abian, J., San Segundo, B., The defense response of germinating maize embryos against fungal infection: A proteomics approach. Proteomics 2004, 4, 383-396. 
[21] Wang, J. M., Chen, J. X., Dai, F., Wu, F. B., et al., Protein fractions in barley grains as affected by some agronomic factors and their relationships to malt quality. Cereal Res. Commun. 2007, 35, 129-140.

[22] Zhou, W. C., Eudes, F., Laroche, A., Identification of differentially regulated proteins in response to a compatible interaction between the pathogen Fusarium graminearum and its host, Triticum aestivum. Proteomics 2006, 6, 4599-4609.

[23] Zhou, W. C., Kolb, F. L., Riechers, D. E., Identification of proteins induced or upregulated by Fusarium head blight infection in the spikes of hexaploid wheat (Triticum aestivum). Genome 2005, 48, 770-780.

[24] Geddes, J., Eudes, F., Laroche, A., Selinger, L. B., Differential expression of proteins in response to the interaction between the pathogen Fusarium graminearum and its host, Hordeum vulgare. Proteomics 2008, 8, 545-554.

[25] Adejumo, T. O., Hettwer, U., Karlovsky, P., Occurrence of Fusarium species and trichothecenes in Nigerian maize. Int. J. Food Microbiol. 2007, 116, 350-357.

[26] Klotzel, M., Lauber, U., Humpf, H. U., A new solid phase extraction clean-up method for the determination of 12 type A and B trichothecenes in cereals and cereal-based food by LCMS/MS. Mol. Nutr. Food Res. 2006, 50, 261-269.

[27] ICC, ICC Standard Methods International association for cereal science and technology 1999.

[28] Klose, J., Kobalz, U., 2-Dimensional electrophoresis of proteins - an updated protocol and implications for a functional-analysis of the genome. Electrophoresis 1995, 16, 1034-1059.

[29] Choo, T. M., Martin, R. A., Ho, K. M., Shen, Q., et al., Fusarium head blight and deoxynivalenol accumulation of barley in Eastern Canada: Cultivar response and correlation analysis. Plant Dis. 2004, 88, 837-844.

[30] Boddu, J., Cho, S., Kruger, W. M., Muehlbauer, G. J., Transcriptome analysis of the barley-Fusarium graminearum interaction. Mol. Plant-Microbe Interact. 2006, 19, 407-417.

[31] Boddu, J., Cho, S. H., Muehlbauer, G. J., Transcriptome analysis of trichothecene-induced gene expression in barley. Mol. Plant-Microbe Interact. 2007, 20, 1364-1375.

[32] Choo, T. M., Vigier, B., Shen, Q. Q., Martin, R. A., et al., Barley traits associated with resistance to Fusarium head blight and deoxynivalenol accumulation. Phytopathology 2004, 94, 1145-1150.

[33] Isebaert, S., De Saeger, S., Devreese, R., Verhoeven, R., et al., Mycotoxin-producing Fusarium species occurring in winter wheat in Belgium (Flanders) during 2002-2005. J. Phytopathol. 2009, 157, 108-116.

[34] Jahn-Deesbach, W., Marquard, R., Schipper, A., Untersuchungen über den Einfluß von Sorte und Stickstoffdüngung auf die Eiweißfraktionen von Weizen und Gerste. Z. Acker Pflanzenbau 1970, 132, 151-162.

[35] Shewry, P. R., Halford, N. G., Cereal seed storage proteins: structures, properties and role in grain utilization. J. Exp. Bot. 2002, 53, 947-958.

[36] Emanuel, C., Weihe, A., Graner, A., Hess, W. R., Borner, T., Chloroplast development affects expression of phage-type RNA polymerases in barley leaves. Plant J. 2004, 38, 460-472.

[37] Saski, C., Lee, S. B., Fjellheim, S., Guda, C., et al., Complete chloroplast genome sequences of Hordeum vulgare, Sorghum bicolor and Agrostis stolonifera, and comparative analyses with other grass genomes. Theor. Appl. Genet. 2007, 115, 571-590.

[38] Colombo, N., Emanuel, C., Lainez, V., Maldonado, S., et al., The barley plastome mutant CL2 affects expression of nuclear and chloroplast housekeeping genes in a cell-age dependent manner. Mol. Genet. Genomics 2008, 279, 403-414. 
[39] Moreno-Risueno, M. A., Martinez, M., Vicente-Carbajosa, J., Carbonero, P., The family of DOF transcription factors: from green unicellular algae to vascular plants. Mol. Genet. Genomics 2007, 277, 379-390.

[40] Yanagisawa, S., The Dof family of plant transcription factors. Trends Plant Sci. 2002, 7, 555-560.

[41] Xiang, C. B., Miao, Z. H., Lam, E., DNA-binding properties, genomic organization and expression pattern of TGA6, a new member of the TGA family of bZIP transcription factors in Arabidopsis thaliana. Plant Mol. Biol. 1997, 34, 403-415.

[42] Feng, D. S., Li, Y., Wang, H. G., Li, X. F., Gao, J. R., Isolation and evolution mode analysis of NBS-LRR resistance gene analogs from hexaploid wheat. Plant Mol. Biol. Rep. 2009, 27, 266-274.

[43] Roberts, T. H., Hejgaard, J., Serpins in plants and green algae. Funct. Integr. Genomics 2008, 8, 1-27.

[44] Ballicora, M. A., Iglesias, A. A., Preiss, J., ADP-glucose pyrophosphorylase: a regulatory enzyme for plant starch synthesis. Photosynth. Res. 2004, 79, 1-24.

[45] Wang, Y., Yang, L. M., Xu, H. B., Li, Q. F., et al., Differential proteomic analysis of proteins in wheat spikes induced by Fusarium graminearum. Proteomics 2005, 5, 4496-4503.

[46] Pekkarinen, A. I., Jones, B. L., Trypsin-like proteinase produced by Fusarium culmorum grown on grain proteins. J. Agric. Food Chem. 2002, 50, 3849-3855.

[47] Hollis, T., Honda, Y., Fukamizo, T., Marcotte, E., et al., Kinetic analysis of barley chitinase. Arch. Biochem. Biophys. 1997, 344, 335-342.

[48] Anand, A., Zhou, T., Trick, H. N., Gill, B. S., et al., Greenhouse and field testing of transgenic wheat plants stably expressing genes for thaumatin-like protein, chitinase and glucanase against Fusarium graminearum. J. Exp. Bot. 2003, 54, 1101-1111.

[49] Shin, S. Y., Mackintosh, C. A., Lewis, J., Heinen, S. J., et al., Transgenic wheat expressing a barley class II chitinase gene has enhanced resistance against Fusarium graminearum. J. Exp. Bot. 2008, 59, 2371-2378.

[50] Leah, R., Tommerup, H., Svendsen, I., Mundy, J., Biochemical and molecular characterization of 3 barley seed proteins with antifungal properties. J. Biol. Chem. 1991, 266, 1564-1573. 


\section{Zusammenfassung}

Die Untersuchungen von Emmer und Nacktgerste zeigten, dass Emmer im Vergleich zu Nacktgerste sehr anfällig gegenüber einer Infektion mit F. graminearum und $F$. culmorum ist. Die Anfälligkeit wurde anhand von Fusarium-DNA und FusariumToxinen charakterisiert. Künstlich mit Fusarium infizierte Emmer- und Nacktgerstekörner wiesen im Vergleich zu einer natürlichen Infektion signifikant höhere Gehalte von Fusarium-DNA und Fusarium-Toxinen (DON, 3-Ac-DON) auf. Der größte Teil der Fusarium-DNA und Trichothecene in Emmer und Sommergerste befand sich in den Spelzen. Obwohl Nacktgerste keine Spelze besitzt, welche als mechanische Eintrittsbarriere gegen Fusarium-Infektion dienen kann, waren fünf von sieben Sorten weniger anfällig für eine Fusarium-Infektion als Emmer.

Die künstliche Fusarium-Infektion führte in beiden Kulturarten im Vergleich zu natürlicher Infektion zu einer signifikanten Reduzierung von Ferulasäure, die den Hauptteil der phenolischen Verbindungen in Getreide ausmacht. Der Vergleich von Emmer und Nacktgerste zeigte, dass Nacktgerste mehr Arabinoxylane und Arabinose enthält als Emmer. Dies kann in Nacktgerste dazu führen, dass der Selbstvernetzungsgrad der Arabinoxylane und die Vernetzung mit anderen Zellwandbestandteilen bspw. Zellulose oder Lignin über Phenole und Arabinose erhöht ist. Nacktgerste enthielt im Gegensatz zu Emmer in der löslichen Fraktion der Phenole das Flavonoid Catechin, das nach künstlicher Fusarium-Infektion verstärkt gebildet wurde. Dass Catechin in Emmer nicht vorhanden ist, könnte neben anderen Faktoren, bspw. der Zusammensetzung der Arabinoxylane, die höhere Anfälligkeit gegenüber einer Fusarium-Infektion im Vergleich zu Nacktgerste erklären.

Fusarium-Infektion veränderte auch die Zusammensetzung der Speicherproteine (Gliadin, Glutenin) in Emmer und Weizen. In beiden Kulturarten konnte eine Abnahme

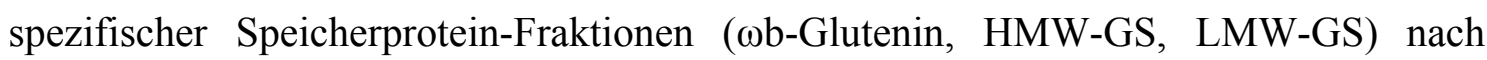
künstlicher Fusarium-Infektion festgestellt werden. Über die Fusarium-Infektion hinaus beeinflussten die Standortbedingungen die Gliadin/Glutenin-Verhältnisse von Emmer und Nacktgerste. Beide Orte unterschieden sich vor allem im Hinblick auf die Stickstoffversorgung, so dass dieser Faktor offensichtlich von Einfluss ist. Bei höherer Stickstoffversorgung nahmen Gliadine und Glutenine in Emmer und Weizen zu. Gliadine wurden in Emmer demnach stärker durch die Stickstoffverfügbarkeit 
beeinflusst als in Weizen, die Glutenin-Fraktionen wurden in beiden Arten gleich stark beeinflusst, dies führte $\mathrm{zu}$ einem engeren Gliadin/Glutenin-Verhältnis, vermutlich beeeinflusst durch höhere Stickstoffversorgung.

In Nacktgerste waren im Vergleich zu den vorher bei Emmer beschriebenen Effekten nach künstlicher Fusarium-Infektion keine Veränderungen in der Zusammensetzung der Speicherproteine erkennbar. Die unterschiedliche Stickstoffversorgung an den beiden Standorten schienen jedoch einen signifikanten Einfluss auf die Speicherproteine der Nacktgerste zu haben. Höhere Stickstoffverfügbarkeit führte zu höheren Gehalten an CHordeinen, $\gamma$-Hordeinen and D-Hordeninen, aber auch $\mathrm{zu}$ einem leicht geringeren Gehalt an B-Hordeninen.

Ein in vitro-Modelversuch zum Abbau von Gliadin und Glutenin mit Proteasen von F. graminearum unterstützt die Vermutung, dass glutenbildene Proteine im Korn bereits auf dem Feld durch pilzliche Proteasen wie „Trypsin-like“ Serineproteasen abgebaut werden können. Wie zuvor an Feldproben von künstlich mit Fusarium infizierten Emmer und Nacktgerste gezeigt werden konnte, war auch in vitro ein stärkerer Abbau der Glutenin-Fraktionen im Vergleich zu den Gliadin-Fraktionen zu beobachten. HMWGS der Glutenine wurden stärker abgebaut als die LMW-GS, was möglicherweise auf ihren höheren Lysingehalt zurückgeführt werden kann. Der isolierte Abbau von Gliadin und Glutenin bestätigte diese Ergebnisse und zeigte, dass nicht nur Glutenine, sondern auch Gliadine durch Fusarium-Proteasen vollständig abgebaut werden wurden. Darüber hinaus konnte in diesem Versuch gezeigt werden, dass durch den Abbau der Glutenine Protein-Fragmente entstehen, die bei einem traditionellen Extraktionsverfahren (bspw. nach Osborne) aufgrund ihrer erhöhten Löslichkeit bereits mit der Gliadin-Fraktion extrahiert werden. Dadurch kann der eigentliche Abbau der Gliadine maskiert werden.

Untersuchungen des Proteoms einer ausgesuchten Emmer- und einer Nacktgerstesorte zeigten nach künstlicher Fusarium-Infektion die Veränderung verschiedener Proteine im Korn, insbesondere von Proteinen, die eine Rolle in der Pathogenabwehr spielen können. Beide Kulturarten zeigten nach Fusarium-Infektion eine Hochregulierung von Serin-Protease-Inhibitoren der Serpin-Gruppe, die Pilzproteasen hemmen und so den Infektionserfolg des Pilzes reduzieren können. Daneben zeigten sich ,pathogenesis related proteins“ (thaumatin-like protein, NBS-LRR-disease-resistant protein) hoch reguliert. Diese können mit dem Pilz interagieren und das Hyphenwachstum sowie die 
Sporulation hemmen. Peroxidasen als Enzyme des Zellredoxsystems bilden als Antwort auf eine Infektion reaktive Sauerstoffspezies. Sie waren in Emmer nach künstlicher Fusarium-Infektion herunter reguliert. Studien zur Fusarium-Infektion, die wenige Tage nach Infektion durchgeführt wurden, beschreiben im Gegensatz dazu eine Induzierung von Peroxidasen. Dies legt nahe, dass $\mathrm{zu}$ unterschiedlichen Entwicklungsstadien in der Ähre verschiedene Abwehrstrategien von Bedeutung sind. Auch in der Proteom-Analyse zeigte sich nach künstlicher Infektion ein Abbau von Speicherproteinen in Emmer ( $\alpha$-Gliadin) und Nacktgerste (D-Hordenin), wie in den Feldproben von Emmer nach Fusarium-Infektion und im in vitro-Versuch mit Fusarium-Proteasen festgestellt werden konnte. 



\section{Summary}

The results of the thesis showed that emmer was highly susceptible to F. graminearum and F. culmorum infection and trichothecene accumulation, but naked barley had a relatively low susceptibility. Most of the fungal biomass and trichothecenes found in emmer and spring barley was located in the glume. Although naked barley does not possess this protective organ, it was in general less susceptible to Fusarium infection than emmer. The phenolic acid contents in the grains of both emmer and naked barley were influenced by Fusarium infection, leading to a significant reduction in the total content of ferulic acid as the predominant phenol in the grains. Comparing the two types of cereals, we found higher arabinoxylane contents in naked barley than in emmer and more arabinose providing a possible site for a phenol involved crosslinking between arabinoxylane backbone and other cell wall compositions. In addition, naked barley grains contained the flavonoid catechin which was significantly higher concentrated after artificial Fusarium infection in comparison to naturally infected samples. Catechin is lacking in emmer and this might be one of the reasons for the higher susceptibility of this species to the fungus. Emmer showed in addition to the basic findings in wheat, new cognitions on the degradation and changes of storage protein subunits by Fusarium infection. Therefore fungal treatment and nitrogen supply led to a species specific effect of the gliadin/glutenin ratio. Comparison of emmer and wheat showed that emmer gliadin proteins were more affected by nitrogen supply as in wheat, in contrast the wheat glutenin fraction changed in the same range as in emmer. Gliadin and glutenin digestion by Fusarium graminearum trypsin-like serine protease investigated in a model system showed a preference for the glutenin subunits in the degradation of gluten. Here the HMW-GS were the most effected fraction resulting from the higher lysine content in this fraction in comparison to LMW-GS. Isolated digestion of gliadin and glutenin by $F$. graminearum proteases confirmed former results, i.e. showed clearly a strong effect also on gliadin degradation. These digestion affected the yield and composition of proteins extracted according to the traditional solvent procedure (Osborne) because glutenin fragments were found in the gliadin extraction solution after digestion. In contrast to the effects visible in emmer naked barley, showed no characteristic changes in protein composition as a reaction to Fusarium infection. The influence of the growing location and nitrogen availability present characteristic changes in the synthesis of barley protein 
types in response to increased nitrogen. The increasing nitrogen supply resulted in a significantly positively affected C-hordeins, $\gamma$-hordeins and D-hordenins but a negatively influenced B-hordenin content. The proteome analysis of a selected emmer and naked barley cultivar showed in connection to Fusarium infection the significant change of specific proteins i.e. involved in defence strategies in late development stages of the grain. In both cultivars the infection leads to an up-regulation of serine protease inhibitors from the serpin group that can inhibit fungal protease and infection success. It also results in the up-regulation of pathogenesis related proteins that can interact with the fungus and inhibit hyphal growth and sporulation. A down regulation of proteins involved in molecular redox regulation in emmer indicated a time dependent management of specific defence mechanisms after fungal infection. Additionally an infection depending degradation of storage proteins is visible in both cultivars and underlines the degradation potential of Fusarium proteases. Nevertheless more studies about the influence of fungal infection for emmer and naked barley cultivars are necessary to enhance the knowledge about plant fungal interaction to clarify practice relevant changes beside extreme artificially infection conditions for grains in general. 


\section{Danksagung}

Für die Unterstützung und Entstehung der Arbeit möchte ich mich besonders bei Frau Prof. Dr. Elke Pawelzik, bei Frau Ulrike Hill für das unermüdliche Aufarbeiten von Proben und die unzähligen Vorbereitungen für die Analysen, Herrn Reinhard Hilmer und Herrn Jürgen Kobbe für die fachliche Unterstützung und Durchführung der Feldversuche sowie bei allen Mitarbeitern der Abteilung Qualität pflanzlicher Erzeugnisse bedanken.

Für die Durchführung der Analysen zur Mykotoxin- und DNA-Analytik sowie die fachliche Unterstützung bei der Interpretation der Daten bedanke ich mich bei Herrn Prof. Dr. Petr Karlovsky der Abteilung Molekulare Phytopathologie und Mykotoxinforschung und im Besonderen bei Frau Sasithorn Limsuwan.

Weiterhin gilt mein Dank allen im Vorwort genannten Züchtern und Instituten für die Bereitstellung von Saatgut, Equipment und Erfahrung für die Analytik und angewandten Methoden.

Bedanken möchte ich mich auch für die Finanzierung meiner Arbeit durch das Niedersächsische Ministerium für Wissenschaft und Kultur im Rahmen des Forschungsverbunds Agrar- und Ernährungswissenschaften Niedersachsen.

Ein besonderer Dank geht an dieser Stelle auch an meine Eltern, die mich im Laufe meiner Ausbildung immer unterstützt und begleitet haben. 



\section{Lebenslauf}

\section{Persönliche Daten}

Vor- und Zunahme:

Kai Eggert

Geburtstag:

11.06.1976

Geburtsort:

Eisenhüttenstadt

Wohnort:

37083 Göttingen, Felix-Klein-Str. 5

Staatsangehörigkeit:

deutsch

Familienstand:

ledig, 1 Kind

\section{Ausbildung}

1983-1991

Puschkin-Oberschule Neuzelle

1991-1993

Gymnasium Neuzelle (mittlere Reife)

1993-1996

Berufsausbildung (Koch)

1996

Weiterbildung: Aufenthalt in Frankreich als Koch

1997

1998-1999

Weiterbildung: Aufenthalt in den USA als Koch

$1999-2000$

2000-2006

07.-09. 2006

Zivildienst (Club Hans Marchwitza in Eisenhüttenstadt)

Fachhochschulreife (OSZ II Frankfurt/Oder)

Studium der Ernährungswissenschaft (Universität

Potsdam)

Projektarbeit (Abt. Lebensmittelchemie Universität

Potsdam)

11. 2006-03. 2007

Projektarbeit (Landeslabor Brandenburg)

Seit 2007

Dissertation (Georg-August-Universität Göttingen) 